LUCIANA TIEMI KATAOKA

ANÁLISE DA DEFORMABILIDADE POR FLUÊNCIA E RETRAÇÃO E SUA UTILIZAÇÃO NA MONITORAÇÃO DE PILARES DE CONCRETO 
LUCIANA TIEMI KATAOKA

\section{ANÁLISE DA DEFORMABILIDADE POR FLUÊNCIA E RETRAÇÃO E SUA UTILIZAÇÃO NA MONITORAÇÃO DE PILARES DE CONCRETO}

Tese de doutorado apresentada à Escola Politécnica da Universidade de São Paulo para obtenção do título de doutor em Ciências, Programa de Pós-Graduação em Engenharia Civil

São Paulo 


\section{ANÁLISE DA DEFORMABILIDADE POR FLUÊNCIA E RETRAÇÃO E SUA UTILIZAÇÃO NA MONITORAÇÃO DE PILARES DE CONCRETO}

Tese de doutorado apresentada à Escola Politécnica da Universidade de São Paulo para obtenção do título de doutor em Ciências, Programa de Pós-Graduação em Engenharia Civil

Área de concentração:

Engenharia de Estruturas

Orientador:

Prof. Dr. Túlio Nogueira Bittencourt

São Paulo 
FICHA CATALOGRÁFICA

\section{Kataoka, Luciana Tiemi}

Análise da deformabilidade por fluência e retração e sua

Utilização na monitoração de pilares de concreto / L.T. Kataoka.

-- São Paulo, 2010. 228 p.

Tese (Doutorado ) - Escola Politécnica da Universidade de São Paulo. Departamento de Engenharia de Estruturas e Geotecnica.

1.Fluência dos materiais 2.Concreto (Monitoramento) I.Universidade de São Paulo. Escola Politécnica. Departamento de Engenharia de Estruturas e Geotécnica II.t. 


\section{DEDICATÓRIA}

Dedico este trabalho à minha família e a meu marido. 


\section{AGRADECIMENTOS}

A minha família, marido e amigos pela compreensão, apoio, carinho e incentivo durante todo período de doutorado.

Ao meu orientador Túlio Nogueira Bittencourt pela confiança, orientação e apoio à realização deste trabalho.

Aos professores do Departamento de Engenharia de Estruturas e Geotécnica (PEF) e do Departamento de Engenharia de Construção Civil (PCC) que contribuíram para minha formação.

Aos funcionários do Laboratório de Estruturas e Materiais Estruturais (LEM) pelo apoio na experimentação e contribuições técnicas.

A Furnas Centrais Elétricas S.A. pelo apoio técnico.

Á empresa Engemix pela oportunidade e instalações cedidas.

Aos funcionários do Laboratório da Engemix pelo apoio técnico fundamental na realização dos ensaios.

Aos bibliotecários pelo constante apoio e esclarecimentos na pesquisa bibliográfica.

Ao Departamento de Engenharia de Estruturas e Geotécnica (PEF) pela oportunidade e pelas instalações.

Aos todos os funcionários do Departamento de Engenharia de Estruturas e Geotécnica (PEF) sempre prestativas e eficientes.

À FAPESP - Fundação de Amparo à Pesquisa do Estado de São Paulo, pelo auxílio financeiro à pesquisa. 


\section{RESUMO}

Esta pesquisa consiste no estudo da deformabilidade de estruturas de concreto, decorrente da retração e fluência. Este estudo envolve aspectos de caracterização do concreto por meio de ensaios em laboratório de retração, de fluência e de suas propriedades mecânicas (resistência à compressão, resistência à tração por compressão diametral e módulo de elasticidade). Por meio dessa caracterização, foram obtidos parâmetros experimentais de fluência e retração baseados em traços de concreto utilizados em obras que possam ser confrontados àqueles indicados pelas normas vigentes. Além disso, nove protótipos de pilares com duas taxas de armadura foram mantidos sob carga constante em um ambiente controlado de temperatura e umidade relativa durante 91 dias. O principal objetivo deste ensaio foi o estudo da influência da taxa de armadura na redistribuição de esforços do concreto para armadura devido às propriedades de fluência e retração em protótipos de pilares. Para prever esta redistribuição de esforços, foram feitas simulações numéricas utilizando o Método dos Elementos Finitos. As simulações consideraram tanto o modelos de previsão de fluência e retração disponível no programa quanto os resultados provenientes da caracterização laboratorial. Além disso, foram avaliadas outras formulações teóricas que prevêem as deformações ao longo do tempo em pilares. Um dos modelos de fluência que melhor se ajustou ao traço dos pilares foi calibrado e os resultados alimentaram as formulações teóricas. Os resultados teóricos foram confrontados com os observados na monitoração dos protótipos. Neste contexto, a caracterização das propriedades de fluência e retração do concreto e os indicadores estatísticos que apontam os melhores modelos de previsão representam uma contribuição ao conhecimento do comportamento de materiais usados atualmente, de forma a tornar possível o uso de um modelo eficaz em projetos de estruturas em concreto armado para os concretos estudados. Além disso, o estudo da fluência e retração em protótipos de pilares forneceu um melhor entendimento da redistribuição de tensões do concreto para armadura. Finalmente, o ajuste do modelo de fluência demonstrou ser eficaz para previsão das deformações obtidas experimentalmente.

Palavras-chave: fluência, retração, propriedades mecânicas, concreto, pilar, monitoração. 


\begin{abstract}
This thesis presents the study of the time dependent deformation of concrete structures due to creep and shrinkage. Creep, shrinkage, compressive strength, splitting tensile strength and modulus of elasticity tests were performed in mixtures commonly used in construction. Experimental parameters were obtained from these mechanical characterizations and creep and shrinkage models were evaluated.

Nine short reinforced and non reinforced columns were long term loaded and monitored for 91 days. The tests were performed in a temperature and relative humidity controlled ambient. The redistribution of internal stresses from concrete to reinforcement due to creep and shrinkage were investigated.

In order to analyze the redistribution of internal stresses Finite Element Method simulations were performed. Creep and shrinkage models and experimental data were considered in simulations. Other formulations were also applied to examine the experimental data from columns. One of the creep models which best fit the experimental data of the column mixture characterization was adjusted and the model results were used in these formulations. Numerical results and experimental data were evaluated.

In this context, the characterization of creep and shrinkage of concrete and statistical evaluation of models contribute to know the behaviour of present-day construction materials and makes possible the use of efficiency models. Besides the study of creep and shrinkage in columns enhance the knowledge of internal stresses redistribution. Finally, an updating creep model was successfully applied to concrete experimental data.
\end{abstract}

Keywords: creep, shrinkage, mechanical proprieties, concrete, column, healthy monitoring. 


\section{LISTA DE ILUSTRAÇÕES}

Figura 1.1 - Vista da Ponte do Rio Sorraia monitorada (Fonte: ASSIS, 2007). .......21

Figura 3.1 - Condições empregadas na avaliação paramétrica.............................95

Figura 4.1 - Etapas do programa experimental. ..............................................104

Figura 4.2 - Bastidor de fluência. ............................................................... 108

Figura 4.3 - Pórtico de retração (pórtico e barra de referência)............................109

Figura 4.4 - Forma de fluência.............................................................. 110

Figura 4.5 - Discos superior e inferior ...................................................... 110

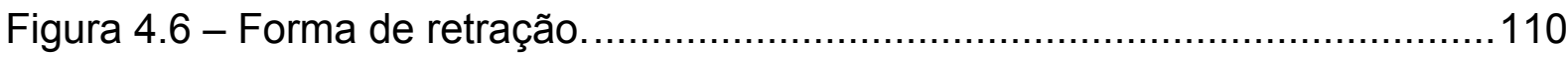

Figura 4.7 - Sensor de deformação de imersão. .........................................112

Figura 4.8 - Sensor de deformação de colagem..........................................112

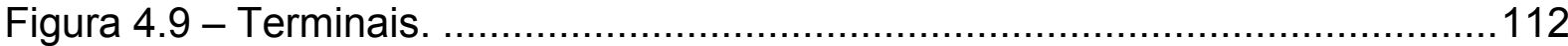

Figura 4.10 - Módulo de expansão e DataTaker DT600. ..................................113

Figura 4.11 - DataTaker DT800 (Fonte: Manual técnico) .................................113

Figura 4.12 - Janela do DeTransfer (Fonte: Manual Técnico)............................ 114

Figura 4.13 - Câmara climatizada. ........................................................ 115

Figura 4.14 - Vista externa da câmara climatizada........................................115

Figura 4.15 - Vista interna da câmara climatizada.......................................116

Figura 4.16 - Equipamento de carregamento. ...........................................118

Figura 4.17 - Ensaio de manutenção de pressão no cilindro................................119

Figura 4.18 - Marcação do fio do sensor e reforço do orifício do disco. .................120

Figura 4.19 - Vedação da forma com uma camada de cera................................120

Figura 4.20 - Nivelamento do disco superior. ........................................... 121

Figura 4.21 - Fixação do disco superior utilizando gesso. .................................121

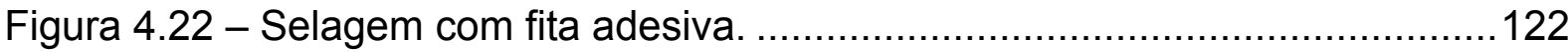

Figura 4.23 - Ensaio de fluência básica......................................................123

Figura 4.24 - Ensaio de fluência por secagem. ...........................................123

Figura 4.25 - Esquema de monitoração de uma série de ensaio de fluência (sem escala).

Figura 4.26 - Adensamento com haste plástica........................................126

Figura 4.27 - Adensamento com martelo de borracha. ................................126 
Figura 4.28 - Acabamento com haste plástica..............................................126

Figura 4.29 - Topo do corpo de prova de retração. ..............................................127

Figura 4.30 - Fixação dos pinos na desmoldagem..........................................127

Figura 4.31 - Ensaio de retração pro secagem............................................128

Figura 4.32 - Detalhamento dos pilares com taxa de armadura 2,8 e 1,4\%..........133

Figura 4.33 - Instrumentação longitudinal dos protótipos de pilares. ....................135

Figura 4.34 - Instrumentação transversal dos protótipos de pilares. .....................135

Figura 4.35 - Superfície da armadura preparada para colagem do sensor. ...........136

Figura 4.36 - Proteção dos sensores da armadura. ..........................................137

Figura 4.37 - Posicionamento dos espaçadores............................................137

Figura 4.38 - Posicionamento dos sensores de imersão no concreto. ....................137

Figura 4.39 - Sensor de concreto centralizado na armadura. .............................137

Figura 4.40 - Instrumentação dos protótipos com taxa de 2,8\% de armadura

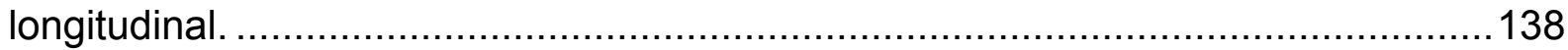

Figura 4.41 - Instrumentação dos protótipos com taxa de 1,4\% de armadura

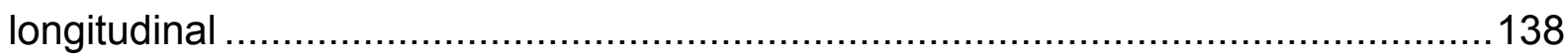

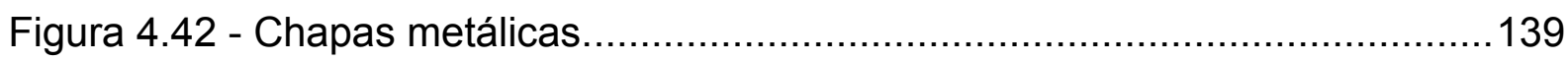

Figura 4.43 - Chapas de polipropileno........................................................139

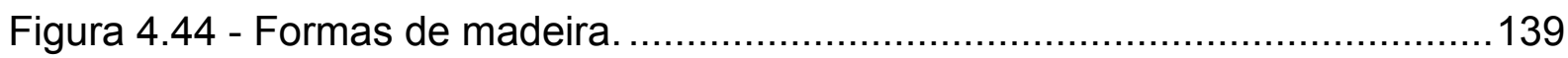

Figura 4.45 - Moldagem dos protótipos de pilares. …………..........................140

Figura 4.46 - Moldagem dos corpos de prova cilíndricos. .....................................140

Figura 4.47 - Ensaio de fluência dos protótipos de pilares....................................141

Figura 6.1 - Modelo de Maxwell-Chain (Fonte: Manual do Diana)........................178

Figura 6.2 - Modelos numéricos dos protótipos de pilares (1,4, 2,8 e 0\%) ............179

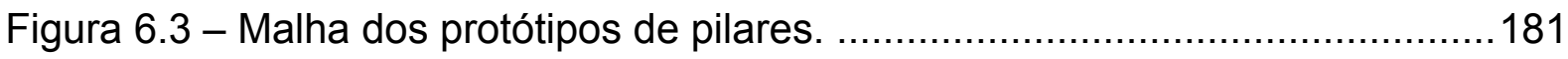

Figura 6.4 - Elemento CHX60 (Fonte: Manual do Diana)...................................181

Figura 6.5 - Elemento L6TRU (Fonte: Manual do Diana). ...................................181

Figura A.1 - Esquema de cálculo para a previsão da deformação da barra.............216

Figura A.2 - Instrumentação da armadura......................................................217

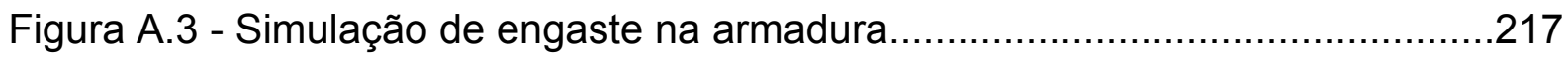

Figura A.4 - Peso utilizado para deformação da armadura.....................................217

Figura B.1 - Circuito de 1/4 de ponte com três vias (ponte de Wheatstone).............218

Figura B.2 - Circuito de 1/4 de ponte com duas vias (ponte de Wheatstone)..........218

Figura B.3 - Circuito de 1/2 de ponte com duas vias (ponte de Wheatstone)..........219 
Figura B.4 - Configuração da ponte de Wheatstone com sensor elétrico (Fonte:

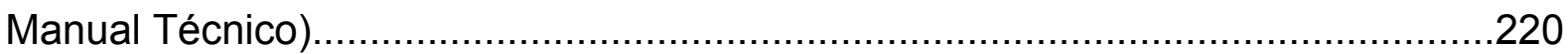

Figura B.5 - Configuração da ponte de Wheatstone com sensor elétrico (Fonte: Manual Técnico). 220

Figura B.6 - Configuração da ponte de Wheatstone com sensor elétrico (Fonte: Manual Técnico). 220

Figura C.1 - Isobanda de deformação no concreto no Diana (ACl). 222

Figura C.2 - Isobanda de deformação na armadura no Diana $(\mathrm{ACl})$.....................222

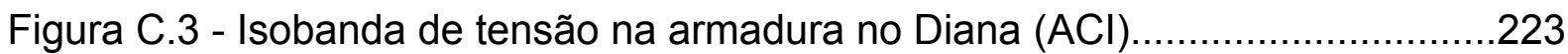

Figura C.4 - Isobanda de deformação no concreto no Diana (CP) .......................223

Figura C.5 - Isobanda de deformação na armadura no Diana (CP).....................223

Figura C.6 - Isobanda de tensão na armadura no Diana (CP) ..........................224

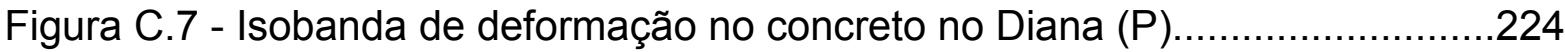

Figura C.8 - Isobanda de deformação na armadura no Diana (P) ......................224

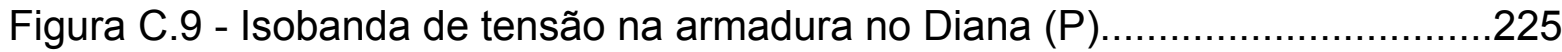

Figura C.10 - Isobanda de deformação no concreto no Diana (ACI) ....................225

Figura C.11 - Isobanda de deformação na armadura no Diana (ACI)..................225

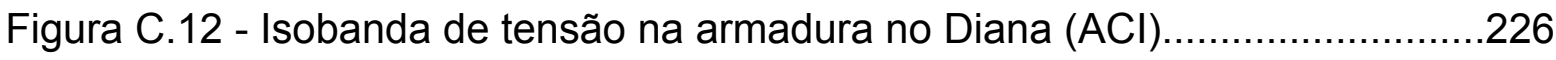

Figura C.13 - Isobanda de deformação no concreto no Diana (CP)....................226

Figura C.14 - Isobanda de deformação na armadura no Diana (CP) ...................226

Figura C.15 - Isobanda de tensão na armadura no Diana (CP) ........................227

Figura C.16 - Isobanda de deformação no concreto no Diana $(P) \ldots \ldots \ldots \ldots \ldots \ldots \ldots . . .227$

Figura C.17 - Isobanda de deformação na armadura no Diana (P)....................227

Figura C.18 - Isobanda de tensão na armadura no Diana $(P) \ldots \ldots \ldots \ldots \ldots \ldots \ldots \ldots \ldots \ldots \ldots \ldots \ldots \ldots \ldots \ldots \ldots . . . \ldots 228$ 


\section{LISTA DE GRÁFICOS}

Gráfico 2.1 - Deformação dependente do tempo em concreto submetido à carga constante (Fonte: NEVILLE, 1997).

Gráfico 2.2 - Exemplo do princípio da superposição de deformações de McHenry (Fonte: NEVILLE, 1997).

Gráfico 2.3 - Reversibilidade da retração por secagem (Fonte: MEHTA; MONTEIRO, 2008).

Gráfico 2.4 - Reversibilidade da fluência (Fonte: MEHTA; MONTEIRO, 2008).....

Gráfico 2.5 - Influência do tipo de agregado na retração por secagem e na fluência. (Fonte: TROXELL et al. apud METHA; MONTEIRO, 2008).

Gráfico 2.6 - Fluência em concretos carregados a 28 dias e mantidos em diferentes umidades relativas (Fonte: NEVILLE, 1997).

Gráfico 2.7 - Retração em concretos mantidos em diferentes umidades relativas (Fonte: NEVILLE, 1997).

Gráfico 2.8 - Influência do tamanho da peça e da umidade relativa no coeficiente de fluência (Fonte: MEHTA; MONTEIRO, 2008)...

Gráfico 2.9 - Influência do tempo de exposição e tamanho da peça sobre o coeficiente de retração por secagem (Fonte: MEHTA; MONTEIRO, 2008). 44

Gráfico 2.10 - Curvas de $\varepsilon_{c c f}(t)$ (Fonte: NBR6118, 2004).

Gráfico 2.11 - Ábaco da variação $\beta_{f}(t)$ em relação à idade fictícia do concreto em dias (Fonte: NBR6118, 2004).

Gráfico 2.12 - Variação de $\beta_{s}(t)$ em relação ao tempo em dias (Fonte: NBR6118, 2004).

Gráfico 2.13 - Comparação do ACl com o RILEM data bank (Fonte: GARDNER, 2004).

Gráfico 2.14 - Comparação do B3 com o RILEM data bank (Fonte: GARDNER, 2004).

Gráfico 2.15 - Comparação do GL com o RILEM data bank (Fonte: GARDNER, 2004). 
Gráfico 2.16 - Comparação do CEB com o RILEM data bank (Fonte: GARDNER, 2004).

Gráfico 2.17 - Modelos de fluência e resultados experimentais (Fonte: ALMEIDA, 2006).

Gráfico 2.18 - Deformação por fluência e retração do concreto (Fonte: TAKEUTI, 2003).

Gráfico 2.19 - Deformação de retração por secagem do concreto (Fonte: MILLER, 2008).

Gráfico 2.20 - Exemplo de calibração da fluência do modelo B3 (fonte: Bažant, 2001).

Gráfico 2.21 - Deformações por fluência e retração no corpo de prova e pilar (Fonte: HOLM; PISTRANG, 1966).

Gráfico 2.22 - Deformações por fluência e retração no corpo de prova e pilar (Fonte: ZIEHL; CLOYD; KREGER, 2004).

Gráfico 2.23 - Deformações por fluência e retração no corpo de prova e pilar (Fonte: ZIEHL; CLOYD; KREGER, 2004).

Gráfico 2.24 - Deformações por fluência e retração em pilares (Fonte: COSTA NETO, 1998). 88

Gráfico 3.1 - Sensibilidade paramétrica dos modelos de fluência. .97

Gráfico 3.2 - Sensibilidade paramétrica dos modelos de retração. .98

Gráfico 4.1 - Temperatura e umidade relativa ambiente da câmara climatizada....117

Gráfico 4.2 - Avaliação da manutenção de pressão no cilindro.

Gráfico 5.1 - Deformação por fluência e retração do concreto (Traço I). 144

Gráfico 5.2 - Deformação por fluência e retração do concreto (Traço II). 145

Gráfico 5.3 - Deformação por fluência e retração do concreto (Traço III). 145

Gráfico 5.4 - Fluência por secagem e básica (Traço I). 146

Gráfico 5.5 - Fluência por secagem e básica (Traço II). 146

Gráfico 5.6 - Fluência por secagem e básica (Traço III).

Gráfico 5.7 - Comparação dos resultados experimentais e numéricos de fluência por secagem (Traço I).

Gráfico 5.8 - Comparação dos resultados experimentais e numéricos de fluência básica (Traço I). 149

Gráfico 5.9 - Comparação dos resultados experimentais e numéricos de fluência por secagem (Traço II). 
Gráfico 5.10 - Comparação dos resultados experimentais e numéricos de fluência por secagem (Traço III).

Gráfico 5.11 - Comparação dos resultados experimentais e numéricos de fluência básica (Traço III).

Gráfico 5.12 - Perda de massa em corpos de prova de retração por secagem (Traço I). 154

Gráfico 5.13 - Deformação de retração por secagem (Traço I). 154

Gráfico 5.14 - Perda de massa em corpos de prova de retração por secagem (Traço III). 155

Gráfico 5.15 - Deformação de retração por secagem (Traço III). 155

Gráfico 5.16 - Perda de massa em corpos de prova de retração por secagem (Traço IV) 156

Gráfico 5.17 - Deformação de retração por secagem (Traço IV). 156

Gráfico 5.18 - Resultados experimentais e do RILEM data bank. 158

Gráfico 5.19 - Resultados experimentais e teóricos (Traço I). . 159

Gráfico 5.20 - Resultados experimentais e teóricos (Traço III). 159

Gráfico 5.21 - Resultados experimentais e teóricos (Traço IV). 160

Gráfico 5.22 - Deformação nas armaduras do pilar F40-2,8-1. 163

Gráfico 5.23 - Deformação no concreto do pilar F40-2,8-1. 163

Gráfico 5.24 - Deformação nas armaduras do pilar F40-2,8-2. 164

Gráfico 5.25 - Deformação no concreto do pilar F40-2,8-2. 165

Gráfico 5.26 - Deformação nas armaduras do pilar F30-2,8-1. 166

Gráfico 5.27 - Deformação no concreto do pilar F30-2,8-1. 166

Gráfico 5.28 - Deformação nas armaduras do pilar F40-1,4-1. 167

Gráfico 5.29 - Deformação no concreto do pilar F40-1,4-1. 167

Gráfico 5.30 - Deformação nas armaduras do pilar F30-1,4-1. 168

Gráfico 5.31 - Deformação no concreto do pilar F30-1,4-1. 169

Gráfico 5.32 - Deformação no concreto do pilar F40-0,0-1. 169

Gráfico 5.33 - Deformação no concreto do pilar R-2,8-1. 170

Gráfico 5.34 - Deformação no concreto do pilar R-1,4-1. 171

Gráfico 5.35 - Deformação no concreto do pilar R-0,0-1. 171

Gráfico 5.36 - Deformação por fluência e retração com tensão de 30\%. 175

Gráfico 5.37 - Deformação por fluência e retração com tensão de 40\%. 176

Gráfico 6.1 - Deformação no concreto $(\mathrm{ACl})$. 


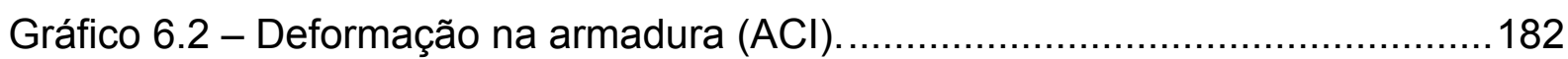

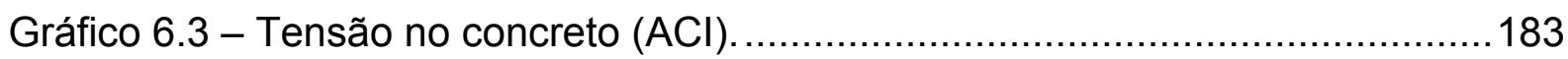

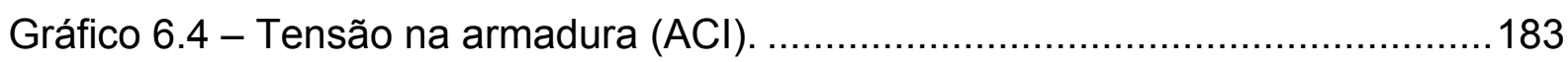

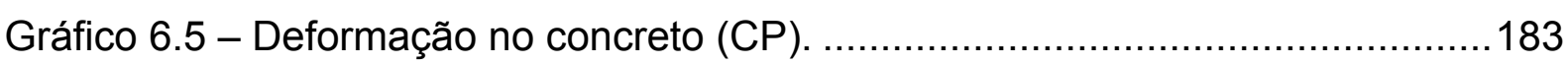

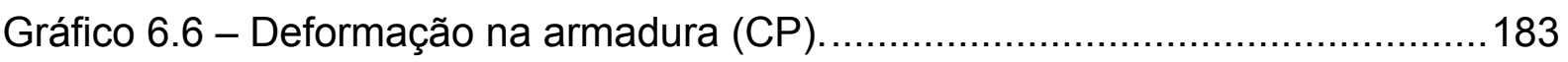

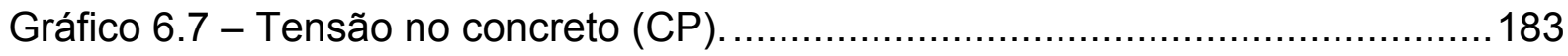

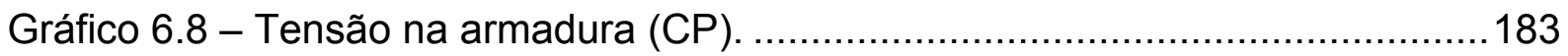

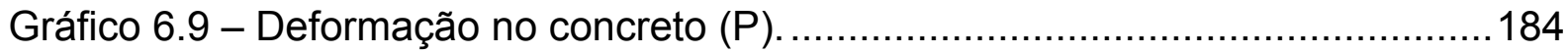

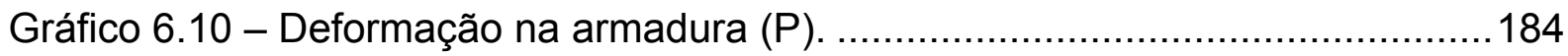

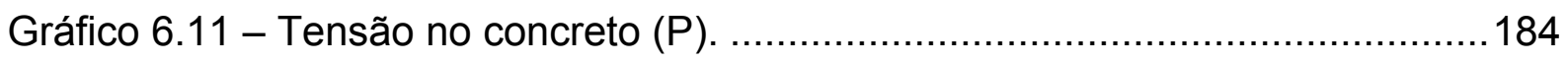

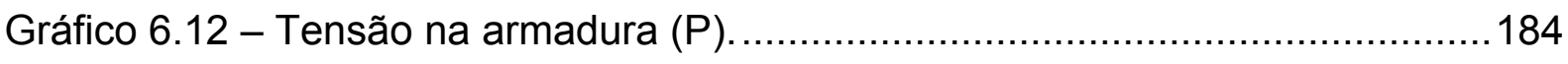

Gráfico 6.13 - Deformação por fluência e retração do protótipo sem armadura (x10 $\left.{ }^{6}\right)$.

Gráfico 6.14 - Deformação por fluência e retração do protótipo com taxa de

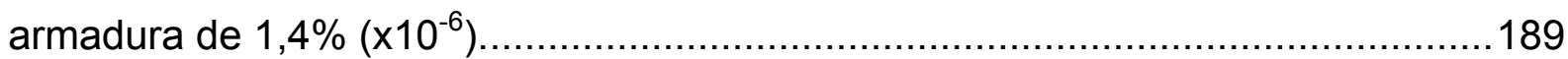

Gráfico 6.15 - Deformação por fluência e retração do protótipo com taxa de

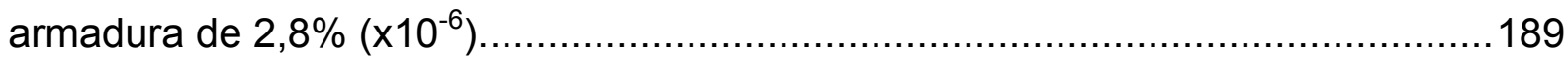

Gráfico 7.1 - Fluência específica calibrada do modelo B3. ..................................193

Gráfico 7.2 - Deformação por fluência e retração considerando ajuste do modelo B3 e do coeficiente de geometria para tensão de 40\% $\left(\times 10^{-6}\right)$...................................194

Gráfico 7.3 - Deformação por fluência e retração considerando ajuste do modelo B3

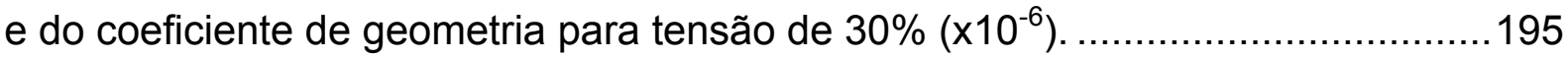

Gráfico 7.4 - Fluência específica calibrada do modelo B3 estendido.......................196

Gráfico A.1 - Resultados experimentais da armadura.......................................217 


\section{LISTA DE TABELAS}

Tabela 2.1 - Tipos de deformação (Fonte: NEVILLE, 1997) …............................27

Tabela 2.2 - Limitações dos modelos de fluência e retração. ..................................47

Tabela 2.3 - Parâmetros de entrada dos modelos de fluência e retração. .................48

Tabela 2.4 - Fator de correção referente ao período de cura inicial úmida...............50

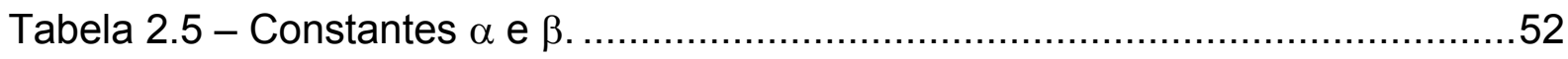

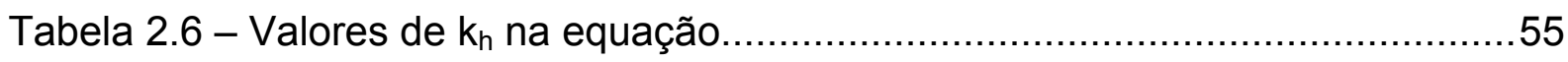

Tabela 2.7 - Valores usuais para a determinação da fluência e da retração (Fonte:

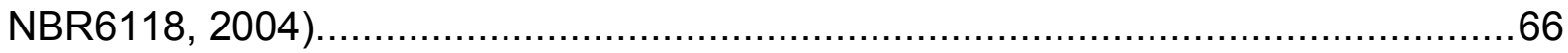

Tabela 2.8 - Valores da fluência e da retração em função da velocidade de endurecimento do cimento (Fonte: NBR6118, 2004) ..........................................

Tabela 2.9 - Valores característicos superiores para a deformação específica de retração $\varepsilon_{c s}\left(\infty, \mathrm{t}_{0}\right)$ e o coeficiente de fluência $\varphi\left(\infty, \mathrm{t}_{0}\right)$ (Fonte: NBR6118, 2004)........68

Tabela 2.10 - Correlação entre os tipos de cimento.............................................68

Tabela 2.11 - Coeficiente de variação $\omega_{\mathrm{B} 3}$ de diversos modelos de fluência para diferentes faixas de idade de carregamento e duração da fluência em dias (Fonte:

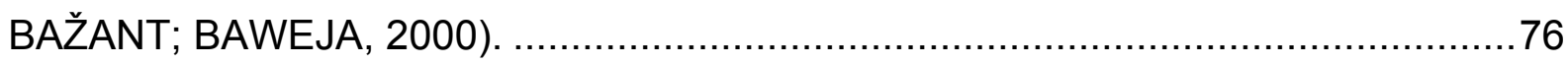

Tabela 2.12 - Coeficiente de variação $\omega_{\mathrm{B} 3}$ de diversos modelos de retração para diferentes faixas de duração de secagem em dias (Fonte: BAŽANT; BAWEJA, 2000).

Tabela 2.13 - Comparação do coeficiente de variação $\omega_{\mathrm{B} 3}$ entre diversos modelos de retração e diferentes concretos (Fonte: VIDELA, 2006) ......................................78

Tabela 2.14 - Estudos de caracterização da fluência e retração em corpos de prova

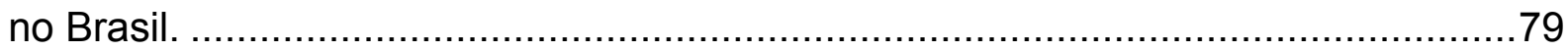

Tabela 2.15 - Características dos pilares ensaiados à fluência e retração................85

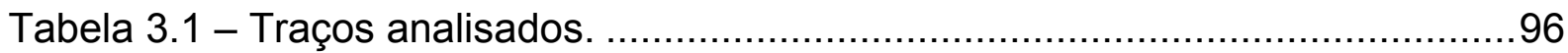

Tabela 4.1 - Traços de concreto convencional estudados para CPIIE40. …...........103

Tabela 4.2 - Planejamento dos ensaios (tração, compressão e módulo)................104

Tabela 4.3 - Planejamento dos ensaios (fluência e retração)................................. 105

Tabela 4.4 - Propriedades físico-químicas do cimento........................................106 
Tabela 4.5 - Caracterização física dos agregados miúdos (areia natural e areia de brita) 106

Tabela 4.6 - Caracterização física dos agregados graúdos (Brita 0 e Brita 1). ......107 Tabela 4.7 - Materiais auxiliares. ............................................................ 111

Tabela 4.8 - Especificações da câmara climatizada de fluência. ...........................114

Tabela 4.9 - Número de protótipos de pilares. ...............................................130

Tabela 4.10 - Detalhes dos protótipos de pilares. ........................................131

Tabela 4.11 - Propriedades físicas e mecânicas das armaduras.........................134

Tabela 5.1 - Propriedades do concreto fresco............................................. 142

Tabela 5.2 - Propriedades mecânicas dos traços I, II, III e IV. ............................143

Tabela 5.3 - Equação logarítmica e R2. ...............................................148

Tabela 5.4 - Coeficientes de variação ${ }^{\omega_{B 3}} \mathrm{e}^{\omega_{B 3, \text { all }}}$ para fluência por secagem (\%).

Tabela 5.5 - Coeficientes de variação ${ }^{\omega_{B 3}} \mathrm{e}^{\omega_{B 3, \text { all }}}$ para fluência básica (\%)........151

Tabela 5.6 - Equação logarítmica e R2. .................................................... 157

Tabela 5.7 - Características dos concretos selecionados do RILEM data bank .... 158

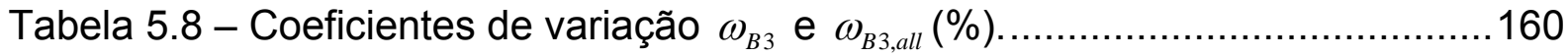

Tabela 5.9 - Deformação da armadura e do concreto $\left(\times 10^{-6}\right)$ aos 91 dias e diferença

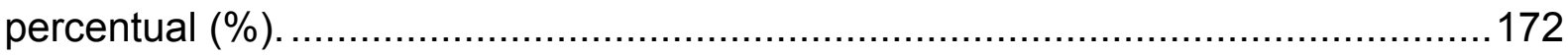

Tabela 5.10 - Fluência específica (x10\%/MPa) e deformação por fluência e retração $\left(\times 10^{-6}\right)$ aos 91 dias

Tabela 5.11 - Restrição das deformações de fluência e retração devido à taxa de

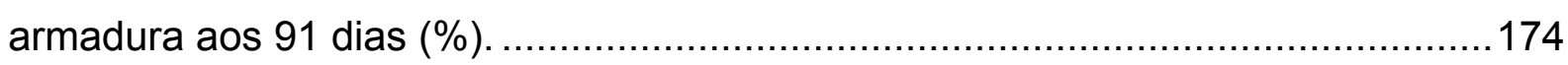

Tabela 6.1 - Propriedades do concreto dos protótipos de pilares ........................180

Tabela 6.2 - Propriedades das armaduras dos protótipos de pilares....................180

Tabela 6.3 - Número de nós e elementos dos modelos numéricos......................181

Tabela 6.4 - Restrição das deformações de fluência e retração devido à taxa de

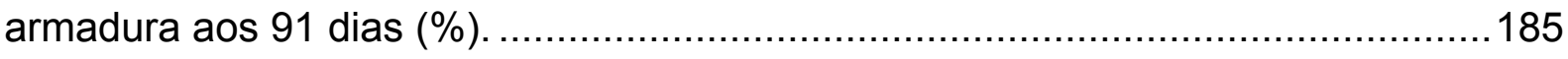

Tabela 6.5 - Deformação de fluência e retração aos 91 dias no concreto $\left(\times 10^{-6}\right)$. 185

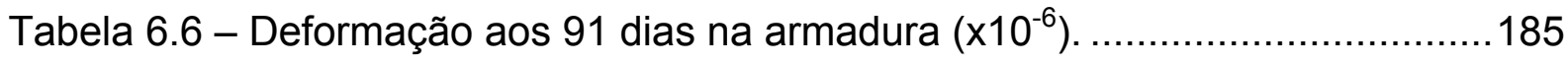

Tabela 6.7 - Transferência de tensão do concreto para armadura aos 91 dias (\%).

Tabela 6.8 - Tensão aos 91 dias na armadura (MPa). 
Tabela 6.9 - Tensão aos 91 dias no concreto (MPa)

Tabela 6.10 - Coeficientes de variação ${ }^{\omega_{B 3}} \mathrm{e}{ }^{\omega_{B 3, a l l}}$ para protótipos de pilares (\%). 188

Tabela 7.1 - Previsão da tensão no concreto aos 91 dias (MPa). 190

Tabela 7.2 - Previsão da deformação no concreto aos 91 dias pelo modelo de Ziehl; Cloyd e Kreger (2004) $\left(\times 10^{-6}\right)$. 191

Tabela 7.3 - Deformação no concreto aos 91 dias pelo modelo de Ziehl; Cloyd e Kreger (2004) ajustado $\left(\times 10^{-6}\right)$. 194

Tabela B.1 - Linhas de comando para sensores. 218 
SUMÁRIO

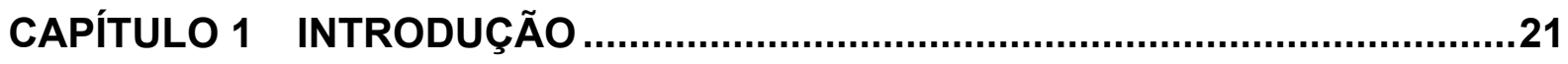

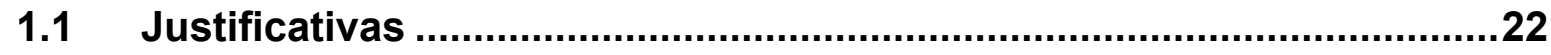

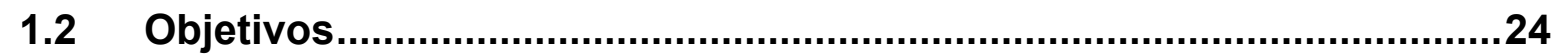

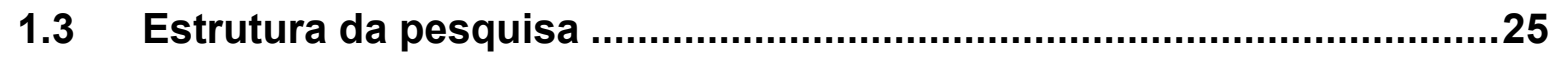

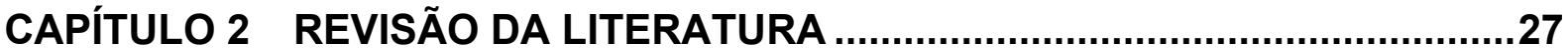

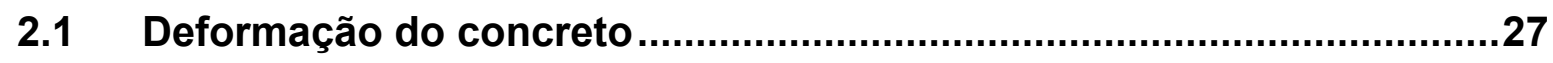

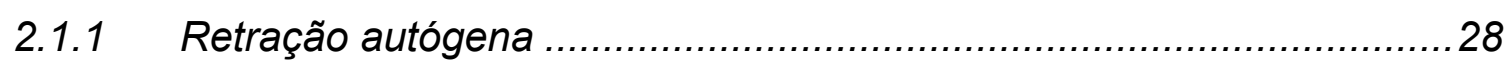

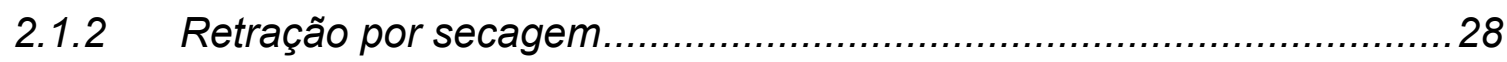

2.1.3 Deformação imediata ou instantânea ...............................................29

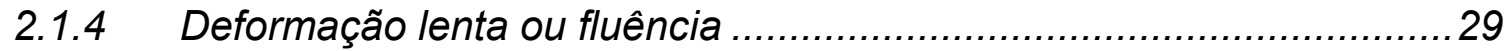

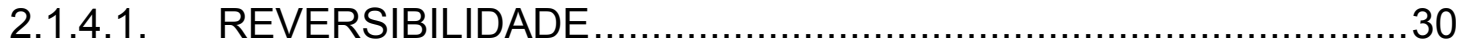

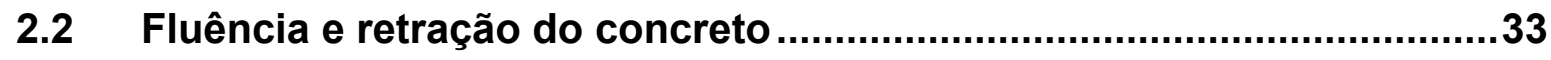

2.2.1 Causas da fluência e retração por secagem....................................... 33

2.2.2 Fatores que influenciam na fluência e retração por secagem............... 35

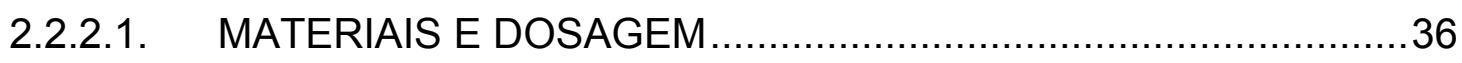

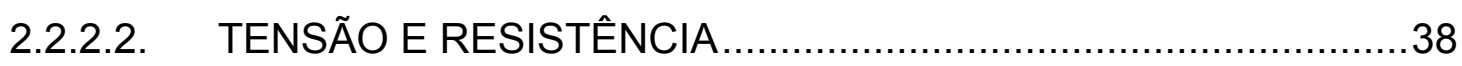

2.2.2.3. PROPRIEDADES DO CIMENTO …….................................... 39

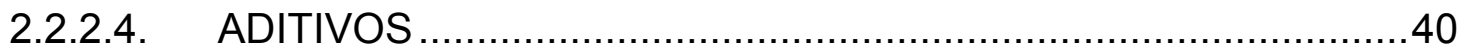

2.2.2.5. UMIDADE RELATIVA DO AMBIENTE E TEMPERATURA ..........41

2.2.2.6. GEOMETRIA DO ELEMENTO …...........................................43

2.2.2.7. IDADE DE CARREGAMENTO ….............................................. 44

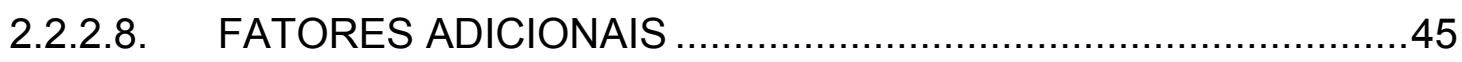

2.2.3 Efeitos da fluência e retração por secagem ...................................... 45

2.3 Modelos para previsão da fluência e retração .......................................47

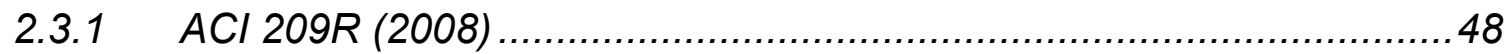

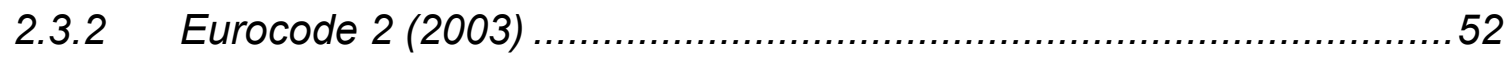

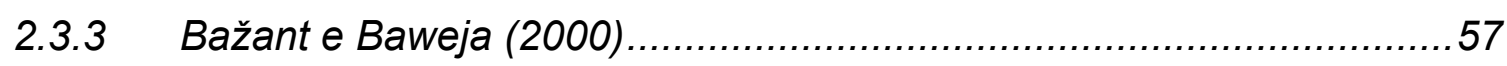

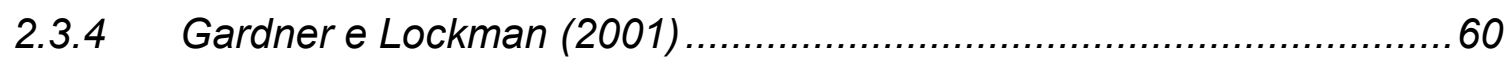

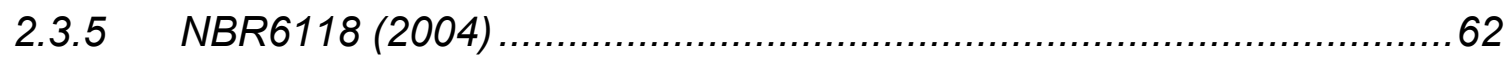


2.3.6 Estudos realizados de comparação entre resultados experimentais e modelos de previsão de fluência e retração.....................................................68

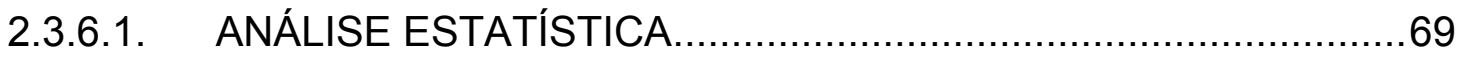

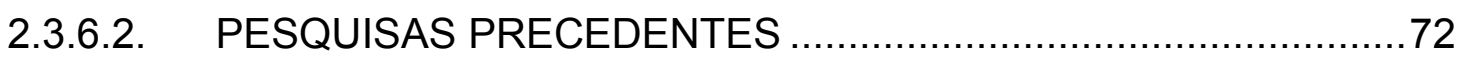

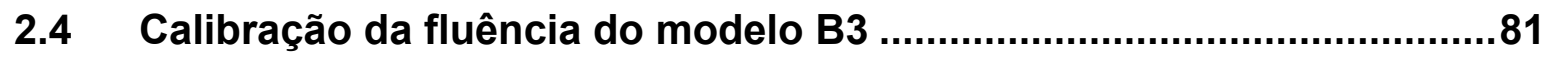

2.5 Fluência e retração em pilares de concreto armado...............................83

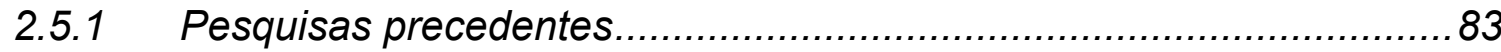

2.5.2 Modelos de previsão da fluência e retração em pilares .........................89

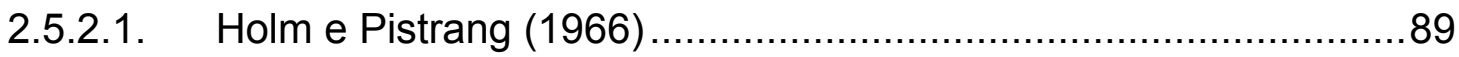

2.5.2.2. Ziehl; Cloyd e Kreger (2004) ...............................................92

CAPÍTULO 3 ANÁLISE PARAMÉTRICA DOS MODELOS ESTUDADOS ............94

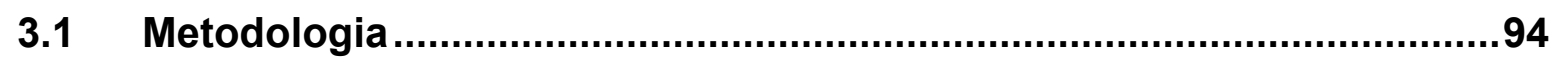

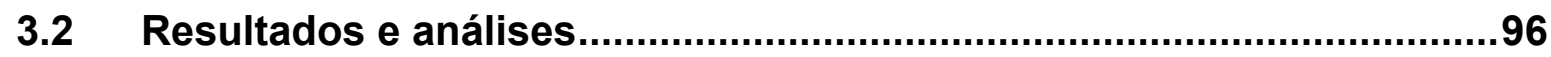

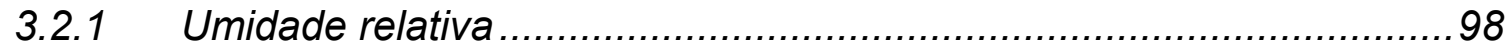

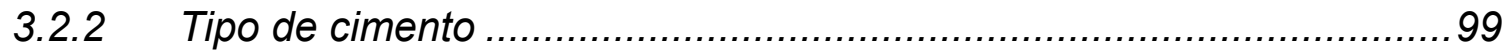

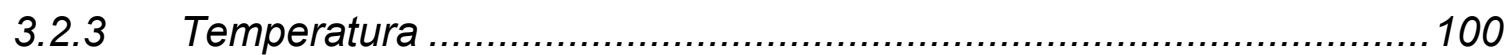

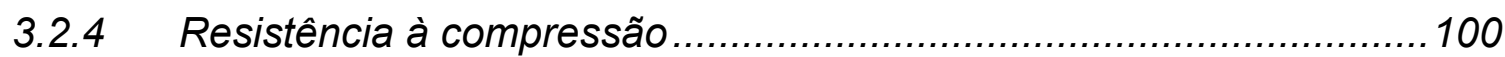

CAPÍTULO 4 PROGRAMA EXPERIMENTAL ...............................................102

4.1 Definição do programa experimental .................................................102

4.2 Materiais empregados nos traços ...................................................105

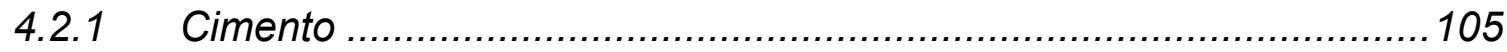

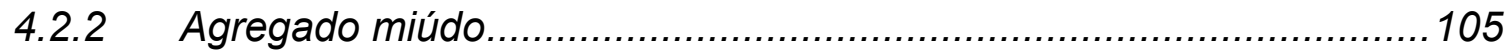

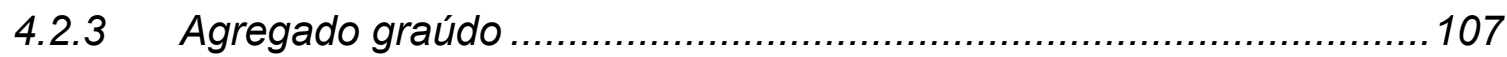

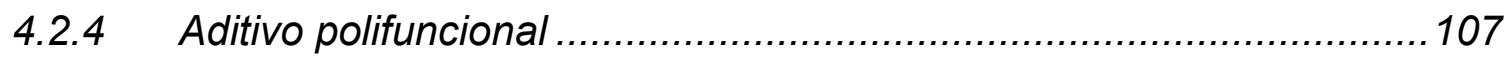

4.3 Equipamentos e materiais dos ensaios de fluência e retração ..........108

4.3.1 Bastidores de fluência e pórticos de retração.................................... 108

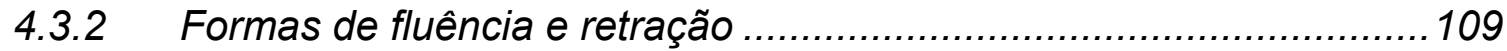

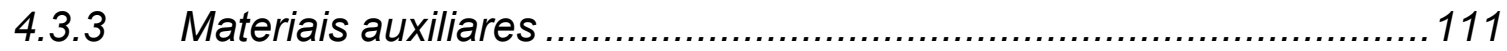

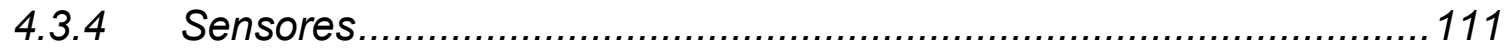

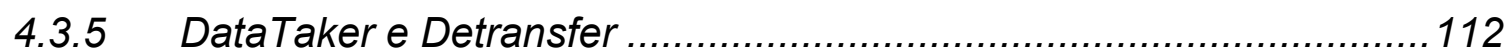

4.3.6 Câmara climatizada para ensaios de fluência e retração ....................114

4.3.7 Equipamento de aplicação de carga..............................................118

4.4 Metodologia do ensaio de fluência..................................................119

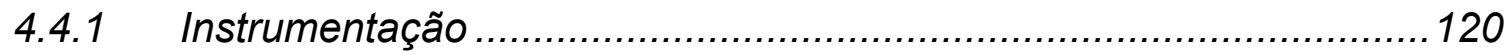




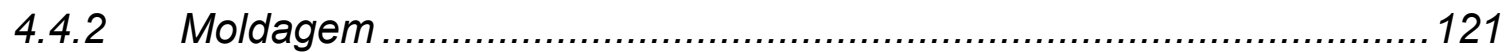

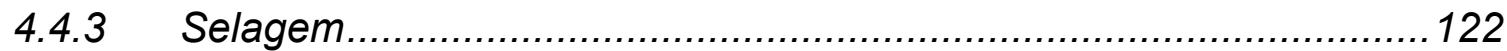

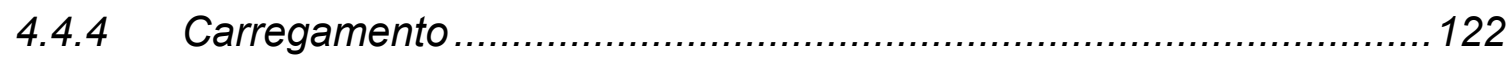

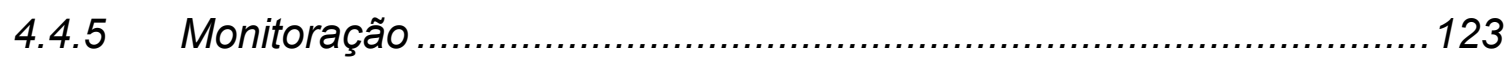

4.4.6 Cálculo das deformações por fluência ...........................................124

4.5 Metodologia do ensaio de retração ……..........................................125

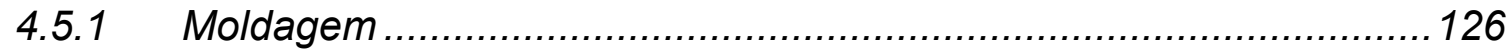

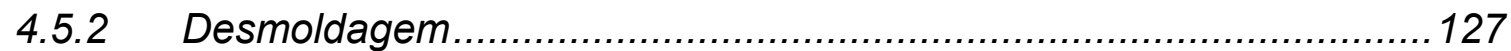

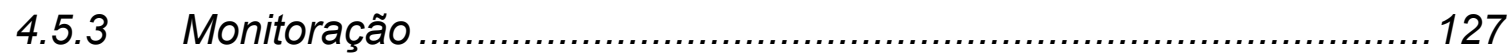

4.5.4 Cálculo das deformações por retração ………................................ 128

4.6 Metodologia do ensaio dos protótipos de pilares................................129

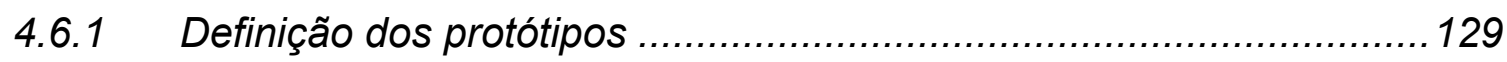

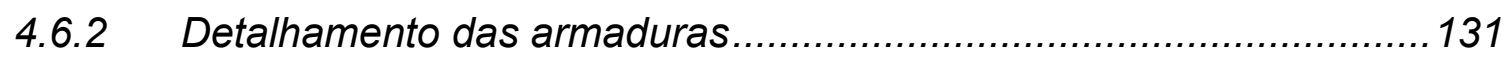

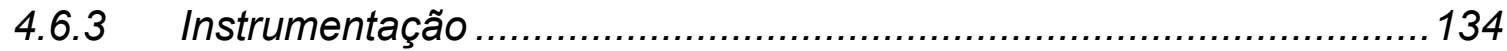

4.6.3.1. INSTRUMENTAÇÃO DAS ARMADURAS ................................135

4.6.3.2. INSTRUMENTAÇÃO DO CONCRETO …...............................137

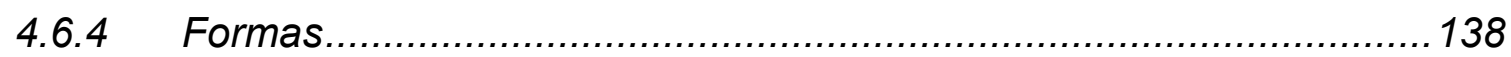

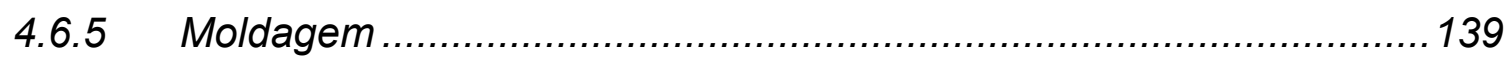

4.6.6 Equipamento de ensaio e monitoração..........................................140

\section{CAPÍTULO 5 RESULTADOS E ANÁLISES DOS ENSAIOS EXPERIMENTAIS 142}

5.1 Propriedades do concreto no estado fresco .....................................142

5.2 Propriedades mecânicas do concreto ……........................................143

5.3 Fluência em corpos de prova ........................................................143

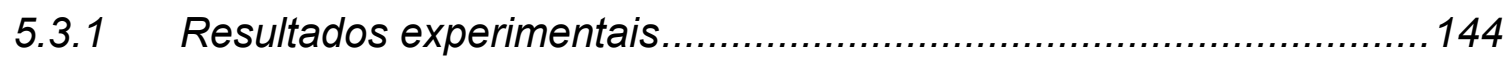

5.3.2 Análises dos resultados experimentais ......................................... 148

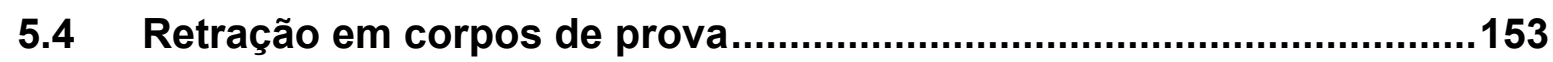

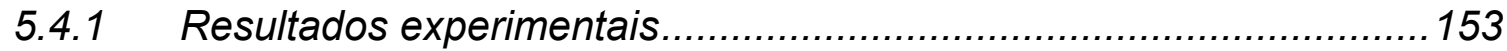

5.4.2 Análises dos resultados experimentais .......................................157

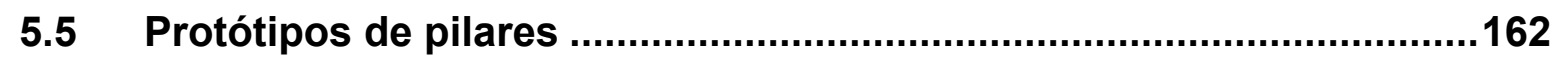

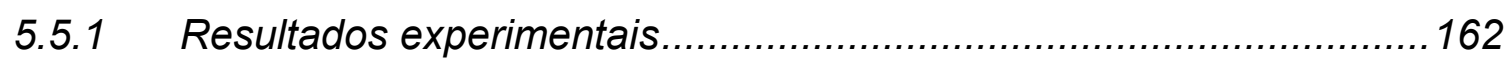

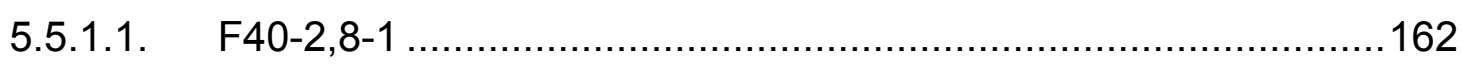

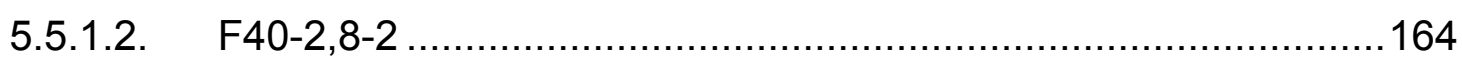

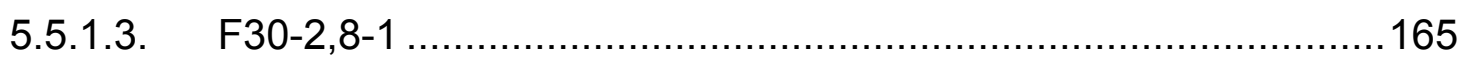

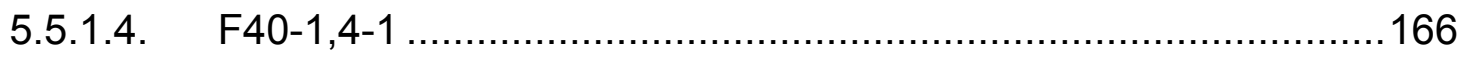




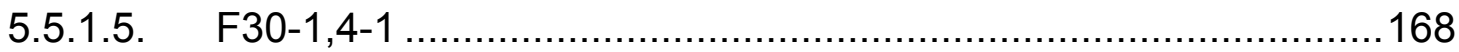

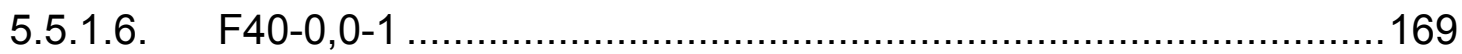

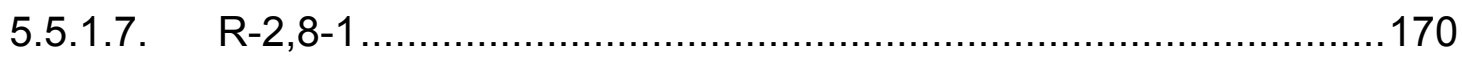

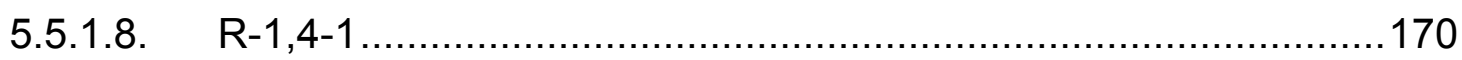

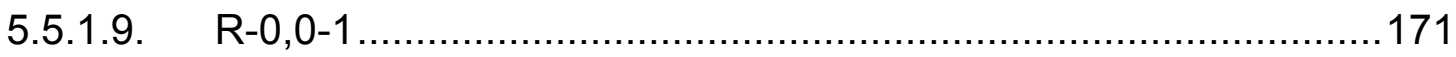

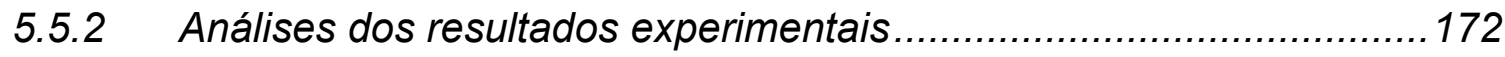

CAPÍTULO 6 SIMULAÇÃO NUMÉRICA DOS PROTÓTIPOS DE PILARES......177

6.1 Modelo de elementos finitos dos materiais ......................................177

6.2 Modelos de fluência e retração no Diana...........................................178

6.3 Modelos numéricos dos protótipos de pilares.....................................179

6.4 Resultados e análises da simulação numérica .....................................181

6.5 Análises dos resultados experimentais e da simulação numérica ....187 CAPÍTULO 7 RESULTADOS E ANÁLISES DA PREVISÃO DA FLUÊNCIA E

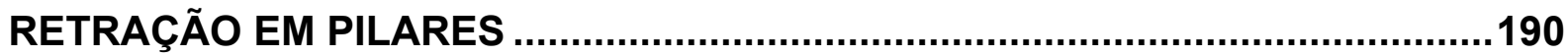

7.1 Calibração do modelo de fluência B3 ….............................................192

CAPÍTULO 8 CONCLUSÕES E TRABALHOS FUTUROS ..................................197

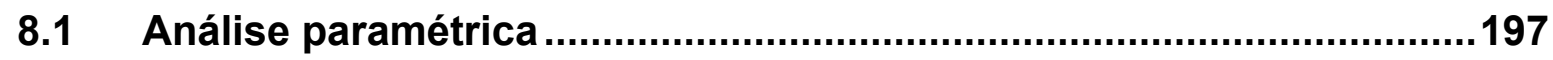

8.2 Fluência e retração dos corpos de prova .............................................199

8.3 Protótipos de pilares em concreto armado .......................................200

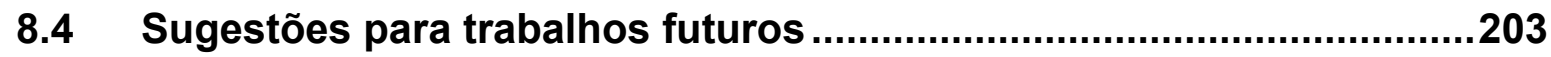

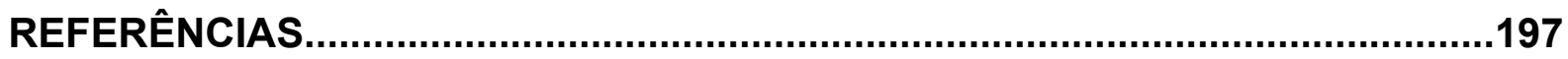

ANEXO A

ANEXO B

ANEXO C

C.1 Isobandas de deformação e tensão no concreto e na armadura para

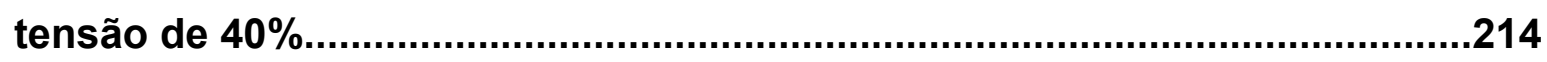

C.2 Isobandas de deformação e tensão no concreto e na armadura para

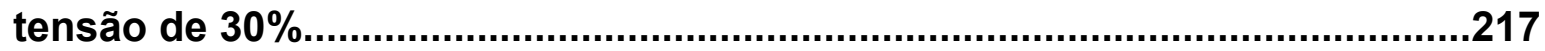




\section{CAPÍTULO 1}

\section{INTRODUÇÃO}

O comportamento ao longo do tempo do concreto, devido às propriedades de fluência e retração, tem considerável influência no desempenho de estruturas em concreto, podendo causar deformação excessivas e redistribuição de tensões (ALMANASSEER; LAM, 2005). Com o passar do tempo, essas deformações excessivas e redistribuição de tensões, se não detectadas e adequadamente tratadas, podem provocar a degradação e, eventualmente, o colapso das estruturas, resultando em consideráveis custos econômicos e sociais (ALMEIDA, 2006). Em geral, a fluência e retração do concreto afetam a durabilidade, as condições em serviço, a integridade estrutural, a estética e a estabilidade da estrutura (GOEL; KUMAR; PAUL, 2007). Neste sentido, a caracterização das propriedades de fluência e retração, assim como a análise estrutural desempenha um papel importante no desenvolvimento do projeto de grandes estruturas.

Para avaliar o desempenho das estruturas de concreto, tem-se utilizado cada vez mais o recurso de monitoração de corpos de prova para caracterização das propriedades de fluência e retração, assim como a monitoração de estruturas reais (ASSIS, 2007 e FÉLIX, 2004), durante a sua construção e após a sua conclusão, como pode ser visto na figura 1.1. Estas informações permitem a aferição dos modelos disponíveis na literatura para previsão da fluência e retração, assim como de parâmetros adotados; a avaliação de critérios de projeto e o acompanhamento da evolução do comportamento destas obras.

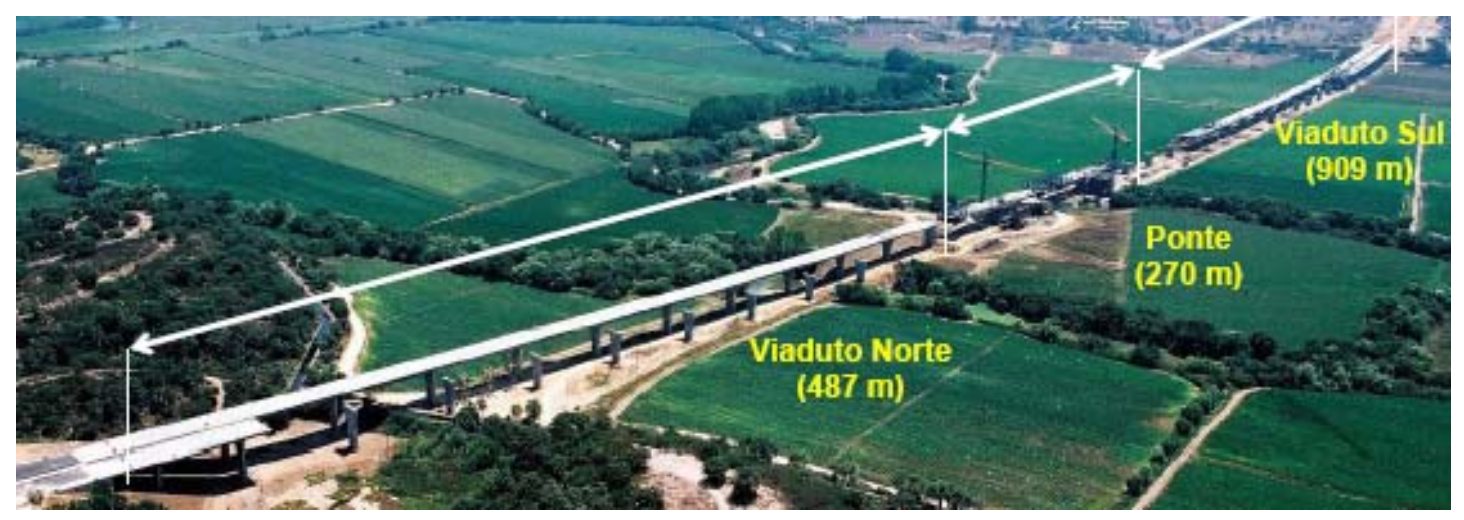

Figura 1.1 - Vista da Ponte do Rio Sorraia monitorada (Fonte: ASSIS, 2007). 
Outro efeito da fluência e da retração é a transferência gradativa de carregamento do concreto para a armadura, em pilares de concreto armado. Esta transferência de carregamento pode causar, mesmo sob níveis de tensões baixas, o escoamento da armadura em pilares subarmados ou a flambagem de pilares carregados excentricamente (NEVILLE, 1997). Em pilares curtos o efeito da fluência causa pequena redução na resistência do concreto (MAUCH, 1965). Além disso, esta redistribuição de esforços também permite que seja determinada a carga atuante em um pilar, no caso da necessidade da transferência de carregamentos devido à remoção de pilares (CASTRO et al., 2008).

Visando contribuir para compreensão do comportamento das propriedades de fluência e retração, nesta pesquisa estas propriedades são caracterizadas em corpos de prova e são estudados pilares de concreto armado, procurando explorar a redistribuição de tensões do concreto para a armadura, que ocorre nestes pilares. Além disso, os resultados experimentais de corpos de prova e protótipos de pilares são confrontados com modelos de previsão de fluência e retração e utilizados como parâmetros de entrada para aferição na simulação numérica.

\subsection{Justificativas}

Embora o estudo da deformabilidade das estruturas de concreto armado, decorrentes das propriedades da retração e fluência tenha sido objeto de estudo de muitos pesquisadores, estas propriedades estão ainda longe de serem totalmente compreendidas (BAŽANT, 2001).

Além disso, a fluência e a retração de peças de concreto, nos últimos tempos, têm sido apontadas como as causas principais de patologias pós-obra, principalmente de rupturas de vedações devido à deformação excessiva dos elementos estruturais. Esta deformação excessiva tem ocorrido, pois os projetos estruturais têm sido elaborados com parâmetros que não representam a deformação por fluência e retração, em virtude dos modelos de previsão não considerarem os significativos avanços no campo de materiais e produtos voltados à construção civil; as decorrentes mudanças nas seções transversais de elementos estruturais e a imposição de um acelerado ritmo de construção (ALMEIDA, 2006; HOWELLS, 
LARK, BARR, 2005). Dessa forma, embora muitos pesquisadores tenham desenvolvido equações sofisticadas de previsão de fluência e retração, a precisão dos modelos para estimar a fluência e retração é ainda baixa (ACl209R, 2008; BAŽANT; BAWEJA, 2000; OJDROVIC e ZARGHAMEE, 1996).

O que mais afeta a imprecisão dos modelos de previsão são os materiais constituintes utilizados. É necessário conhecer o comportamento da fluência e retração de concretos utilizando materiais provenientes de diferentes regiões $\mathrm{e}$ encontrar um modelo apropriado para estas propriedades (VIDELA; AGUILAR, 2006 e AL-MANASSEER; LAM, 2005). Embora haja um banco de dados de fluência e retração (RILEM data bank) contendo resultados do mundo todo, não há resultados de concretos brasileiros neste banco de dados e o comportamento da fluência e retração para concretos feitos com os cimentos brasileiros existentes é pobre e muito incompleto. No Brasil, há poucos resultados de retração autógena e por secagem em concreto convencional, apesar de haver dados consideráveis de fluência básica em concreto (TAKEUTI, 2003; EQUIPE DE FURNAS, 1997; PEREIRA, 2001). Entretanto, são muito escassas as pesquisas de fluência por secagem (KALINTZIS, 2000). Também foi verificado que são raros os resultados em concreto com cimento de escória. A utilização deste tipo de adição nos concretos atuais tem sido crescente considerando as vantagens que a escória apresenta em relação ao cimento convencional (ÁTIS et al., 2007; MURGIER, ZANNI, GOUVENOT, 2004; SCRIVENER; KIRKPATRICK, 2007). Além disso, é importante analisar o comportamento à fluência e retração deste cimento, pois, quando comparado aos cimentos convencionais, apresenta maior retração, fato que supostamente limitaria sua utilização mais abrangente (MELO NETO; CINCOTTO; REPETTE, 2007 e METHA; MONTEIRO, 2008).

Neste sentido, a caracterização das propriedades de fluência e retração de corpos de prova pode trazer informações relevantes para verificação da eficácia dos modelos de previsão e contribuição para o banco de dados do RILEM TC 107-SCP Subcommittee 5 considerando concretos brasileiros (BAŽANT; LI, 2008). Esta caracterização torna possível a previsão de deformações e, conseqüentemente, de falhas estruturais, com importantes reflexos na segurança e no aumento da vida útil de estruturas. Além disso, a partir de resultados experimentais é possível obter parâmetros e ajustá-los nos modelos de previsão. 
A aplicação prática do estudo de caracterização das propriedades de fluência é feita por meio da monitoração de deformações ao longo do tempo de protótipos de pilares em laboratório, para o estudo da transferência gradativa de carregamento do concreto para a armadura. Esta redistribuição de esforços permite, por exemplo, a determinação da tensão existente nas armaduras para determinação da carga que o pilar está submetido (CASTRO et al., 2008), assim como a avaliação da influência da taxa de armadura. Além disso, se há necessidade de prever com maior precisão as deformações por fluência e retração, é fundamental avaliar numérico e experimentalmente estas propriedades ao longo do tempo tanto para protótipos de concreto quanto para corpos de prova (BAŽANT; BAWEJA, 2000 e GARDNER; LOCKMAN, 2001).

Por fim, os resultados experimentais de fluência e retração provenientes dos pilares e dos corpos de prova confrontados com os resultados analíticos permitem a melhor compreensão das propriedades estudadas.

\subsection{Objetivos}

O objetivo principal deste trabalho é estudar a deformabilidade do concreto devido às propriedades de fluência e retração.

Como objetivos específicos desta pesquisa destacam-se os indicados abaixo:

- Construção de uma infra-estrutura laboratorial que permitisse a realização dos ensaios programados;

- Caracterização da fluência e retração de quatro traços comerciais de concreto utilizados em obras que possam ser confrontados àqueles indicados por normas vigentes, fornecendo indicadores estatísticos dos modelos de previsão mais eficazes. Além disso, também se tem como objetivo avaliar o crescimento das resistências à tração e à compressão, assim como do módulo de elasticidade com o tempo;

- Projeto, instrumentação e monitoração de protótipos de pilares para análise da fluência e retração com a finalidade de avaliar a influência da taxa de armadura na transferência de carregamento gradativa do concreto para 
armadura. Para isso, foram confeccionados, em laboratório, protótipos que permitiram a avaliação deste fenômeno;

- Simulação numérica dos protótipos de pilares utilizando um programa computacional baseado no Método dos Elementos Finitos (Diana 9.3) para avaliar e prever o comportamento experimental dependente do tempo. Nesta simulação utilizaram-se o modelo do ACI209 (1982) disponível no programa e curvas experimentais de fluência e retração;

- Comparação e análise de modelos de previsão de fluência e retração disponíveis na literatura (ACI209R, 2008 - ACl, BAŽANT E BAWEJA, 2000 - B3, EUROCODE 2, 2003 - EC2, GARDNER E LOCKMAN, 2001 - GL E NBR6118, 2004 - NBR) e resultados experimentais de caracterização de corpos de prova e protótipos, assim como a aferição de um dos modelos de fluência que melhor se ajustou aos resultados obtidos experimentalmente dos protótipos.

\subsection{Estrutura da pesquisa}

Esta pesquisa está estruturada em oito capítulos:

O primeiro capítulo é constituído pela introdução, justificativas, objetivos e estrutura da pesquisa.

O segundo capítulo apresenta a conceituação das deformações do concreto, assim como são discutidas as causas, os fatores que influenciam e os efeitos da fluência e da retração. Além disso, são apresentados os modelos de previsão da fluência e retração, assim como a comparação entre estes modelos e resultados experimentais de outros autores, levando em consideração a análise estatística. Este capítulo finaliza com a revisão bibliográfica de pesquisas relacionadas com a deformabilidade ao longo do tempo de pilares de concreto armado e modelos de previsão que consideram a transferência de carregamento devido às deformações por fluência e retração. 
O terceiro capítulo apresenta uma análise dos modelos de previsão da fluência e retração, assim como da variação dos parâmetros que influenciam os modelos de fluência e retração.

No quarto capítulo é feita uma abordagem detalhada do programa experimental dos ensaios de fluência e retração em corpos de prova e protótipos de pilares. Estão descritos os equipamentos, materiais, traços e a metodologia utilizada para os ensaios, tanto em corpos de prova quanto nos protótipos de pilares.

No quinto capítulo estão apresentados os resultados experimentais e discussões dos resultados obtidos de fluência e retração em corpos de prova e protótipos de pilares.

No sexto capítulo é feita a simulação numérica dos protótipos de pilares, assim como são apresentados os resultados e análises. Além disso, são apresentadas as análises envolvendo os resultados da simulação numérica e resultados experimentais (corpos de prova e protótipos de pilares).

No sétimo capítulo são apresentados os resultados teóricos e análises da previsão da transferência de carregamento dos pilares.

No oitavo capítulo estão descritas as observações e conclusões obtidas nesta pesquisa, assim como são feitas algumas sugestões para trabalhos futuros relacionados com a deformabilidade do concreto ao longo do tempo. 


\section{CAPÍTULO 2 \\ REVISÃO DA LITERATURA}

\subsection{Deformação do concreto}

No concreto submetido a carregamento, assim como em vários outros materiais, as deformações podem ser elásticas (reversíveis), viscoelásticas (parcialmente reversíveis, consistindo de uma fase viscosa e outra elástica) e plásticas (não reversíveis) conforme tabela 2.1 (NEVILLE, 1997).

A deformação elástica é instantânea, linear e sempre recuperável com o descarregamento. Portanto, a relação tensão deformação é dada pela Lei de Hooke.

A deformação plástica é instantânea, irreversível, sem variação volumétrica do material e não existe proporcionalidade entre deformação plástica e tensão aplicada, ou entre tensão e velocidade de deformação (NEVILLE, 1997).

A deformação viscosa é irreversível no descarregamento, sempre depende do tempo e existe proporcionalidade entre a velocidade de deformação viscosa e a tensão aplicada. A elasticidade retardada é totalmente reversível já que a energia produzida não é dissipada, mas armazenada no material (NEVILLE, 1997).

Tabela 2.1 - Tipos de deformação (Fonte: NEVILLE, 1997).

\begin{tabular}{ccc}
\hline Tipo de deformação & Instantânea & Dependente do tempo \\
\hline Reversível & Elástica & Elástica retardada \\
Irreversível & Plástica & Viscosa \\
\hline
\end{tabular}

Além das deformações devido à carga aplicada, há deformações inerentes do concreto causadas pela perda de água, demominada de deformação por retração. Dessa forma, as deformações no concreto podem ser classificadas da seguinte maneira: retração plástica, retração autógena, retração por secagem, retração por carbonatação, deformação térmica, deformação imediata ou instantânea e deformação lenta ou fluência. Nesta pesquisa, são estudadas as propriedades de 
retração autógena, retração por secagem, deformação imediata ou instantânea e deformação lenta ou fluência.

\subsubsection{Retração autógena}

Retração autógena é a redução de volume do material cimentício na hidratação do cimento após o início da pega. Esta retração é conseqüência da remoção de umidade dos poros capilares pela hidratação do cimento ainda não hidratado. A redução de volume que ocorre na retração autógena não é causada pela perda ou ganho de umidade para o ambiente, variação de temperatura e restrições (TAZAWA; MIYAZAWA, 1993 e NEVILLE, 1997).

A reação química entre o cimento e a água se dá com redução de volume, de tal forma que a água quimicamente combinada (22 a 32\%) sofre uma contração de $25 \%$ de seu volume original (KALINTZIS, 2000).

A contração da pasta de cimento é restringida pelo esqueleto rígido da pasta de cimento já hidratada e também pelas partículas do agregado (NEVILLE, 1997).

A deformação autógena tende a aumentar devido a temperaturas muito altas, teores de cimento maiores e relações água/cimento menores (NEVILLE, 1997).

\subsubsection{Retração por secagem}

Retração por secagem, ou hidráulica é a propriedade que consiste na contração irreversível decorrente da variação de umidade das pastas de cimento, argamassa ou concreto, assim como em outros materiais cuja estrutura interna seja de natureza porosa (EQUIPE DE FURNAS, 1997).

Esta deformação está associada à perda de umidade para o meio ambiente o que a torna uma das principais causas de fissuração e faz com que assuma papel importante, pois sua ocorrência pode afetar a durabilidade do concreto 
(KALINTZIS, 2000). A retração por secagem ocorre juntamente com a retração autógena (TAZAWA; MIYAZAWA, 1993).

\subsubsection{Deformação imediata ou instantânea}

A deformação imediata ou instantânea é a que se apresenta no momento da aplicação da carga. A velocidade de aplicação da carga influencia na deformação instantânea registrada (RÜSCH, 1981).

\subsubsection{Deformação lenta ou fluência}

De acordo com Neville (1997), fluência pode ser definida como o aumento de deformação sob tensão mantida ou, se a deformação for mantida constante a fluência se manifesta como uma redução progressiva da tensão com o tempo denominada relaxação. A fluência geralmente é representada em termos de fluência específica que é a deformação por fluência por unidade de tensão (x10$\left.{ }^{6} / \mathrm{MPa}\right)$.

Rüsch (1981) afirma que a fluência do concreto deve ser atribuída à migração de água causada pela carga externa. Para as camadas de água absorvida da estrutura de gel, bem como o efeito das tensões capilares, ou seja, ao se aplicar a carga no concreto, existe uma distribuição da mesma pelo esqueleto do sólido e pelas águas dos poros.

Mehta e Monteiro (2008) conceituam como fluência básica como todo aumento de deformação ao longo do tempo com tensão constante sob condições de umidade relativa de $100 \%$. Esta condição geralmente surge em estruturas de grande porte onde a retração por secagem pode ser desprezada. A fluência por secagem é uma fluência adicional que ocorre quando a peça está sob carga e sob secagem.

Dessa forma, a fluência total é a soma da fluência básica e da fluência por secagem e a deformação total é a soma da deformação devido à fluência total e a 
deformação por retração. Simplificadamente, a fluência é calculada como a diferença entre a deformação total com o tempo do elemento carregado e a retração de um elemento semelhante descarregado observado nas mesmas condições durante igual período de tempo, gráfico 2.1 (NEVILLE, 1997).

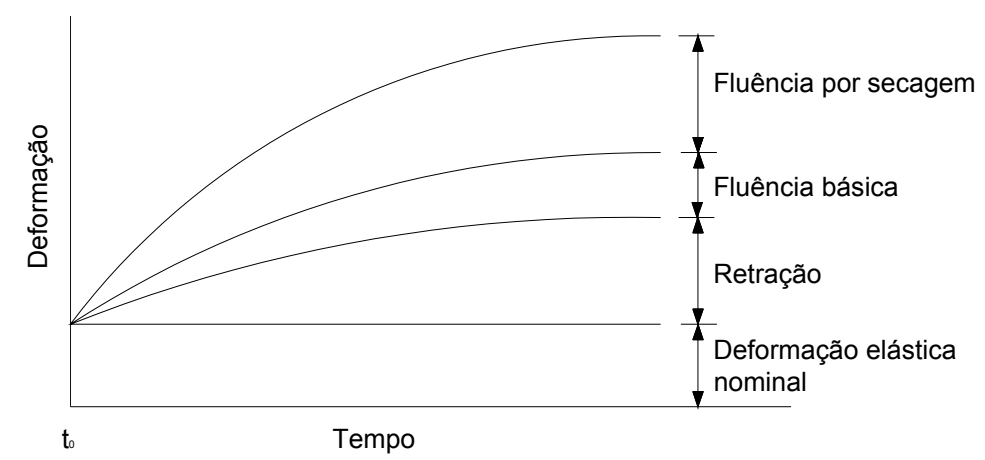

Gráfico 2.1 - Deformação dependente do tempo em concreto submetido à carga constante (Fonte: NEVILLE, 1997).

Em condições normais de carregamento, a deformação instantânea registrada depende da velocidade da aplicação da carga e inclui, portanto, não apenas a deformação elástica, mas também uma parte da fluência. É difícil distinguir a deformação elástica imediata e a fluência inicial, mas isto não tem importância prática, pois é a deformação total devido à aplicação da carga que interessa. Como o módulo de elasticidade do concreto aumenta com a idade, a deformação elástica decresce progressivamente e, a rigor, a fluência deveria ser tomada como a deformação que excede a deformação elástica no momento em que a fluência está sendo determinada (NEVILLE, 1997).

Para fins práticos, se faz uma diferenciação arbitrária: a deformação que ocorre imediatamente ou simultaneamente à aplicação do carregamento é considerada elástica e o aumento subseqüente desta deformação devido à carga constante é considerado como fluência (SAMPAIO, 2004).

\subsubsection{REVERSIBILIDADE}

Segundo Neville (1997), foi desenvolvido por McHenry um tratamento possível da recuperação parcial da fluência a partir do princípio da superposição de 
deformações. Esse tratamento estabelece que as deformações produzidas no concreto a qualquer tempo $\mathrm{t}$ por um incremento de tensão aplicado em um momento qualquer $t_{0}$, são independentes dos efeitos de qualquer tensão aplicada antes ou depois de $t_{0}$. Segue então que, se a tensão é removida à idade $t_{1}, a$ recuperação resultante da fluência será igual à fluência de um elemento semelhante submetido a uma tensão igual de compressão à idade $t_{1}$. $O$ gráfico 2.2 ilustra essa afirmativa, e pode ser visto que a recuperação é representada pela diferença entre a tensão em qualquer momento e a tensão que existiria no mesmo momento se o elemento continuasse submetido à tensão de compressão inicial.

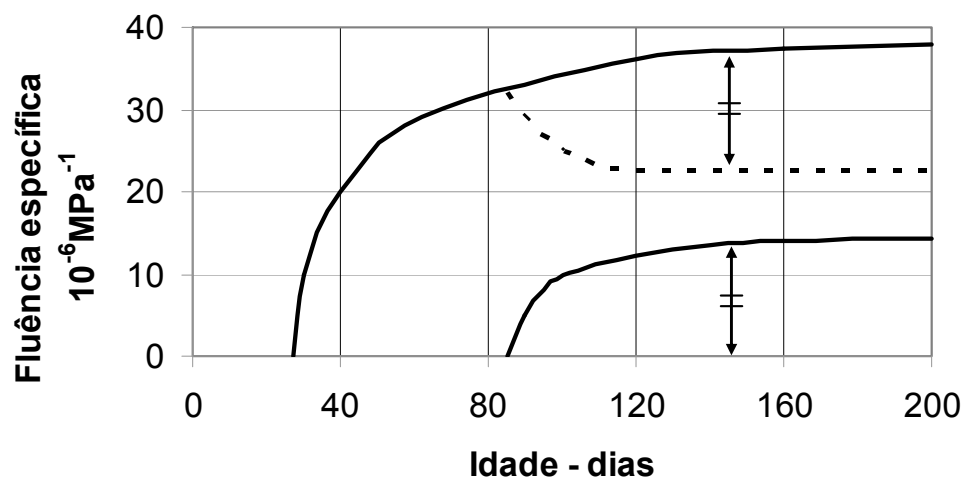

Gráfico 2.2 - Exemplo do princípio da superposição de deformações de McHenry (Fonte: NEVILLE, 1997).

Entretanto, Costa Neto (2004) verificou na literatura que a recuperação da fluência proposta pelo princípio da superposição é maior do que a recuperação real. De fato, Neville (1997) conclui que o princípio da superposição leva a um erro tolerável em condições de cura em concreto massa, ou seja, para fluência básica. Quando se verifica fluência por secagem, o erro é grande pelo fato de que a recuperação é grosseiramente superestimada. Bažant; Li e Yu (2008) também afirmam que não há desvio do princípio da superposição para fluência básica, sendo notada apenas na fluência por secagem. Entretanto, Gardner e Tsuruta (2004) concluem que, para níveis de tensão de 0,25 a 0,4, a reversibilidade tanto da fluência básica quanto por secagem é somente de 70 a $80 \%$ e, portanto, a superposição não é válida nem para concretos sujeitos a secagem ou àqueles selados, em situações que envolvem descarregamento.

Um aspecto relevante citado por Mehta e Monteiro (2008) é que o comportamento típico do concreto na molhagem e na secagem ou no carregamento e descarregamento são bastante semelhante, gráficos 2.3 e 2.4. Tanto a propriedade 
de retração por secagem quanto o de fluência no concreto apresentam um grau de irreversibilidade que possui importância prática. O gráfico 2.3 mostra que após a primeira secagem, o concreto não retornou a sua dimensão original mesmo depois de molhado. A retração por secagem, portanto, foi classificada em retração reversível, que é a parte da retração total reproduzível em ciclos de molhagemsecagem; e retração irreversível, que é a parte da retração total na primeira secagem que não pode ser reproduzida em ciclos subseqüentes de molhagemsecagem.

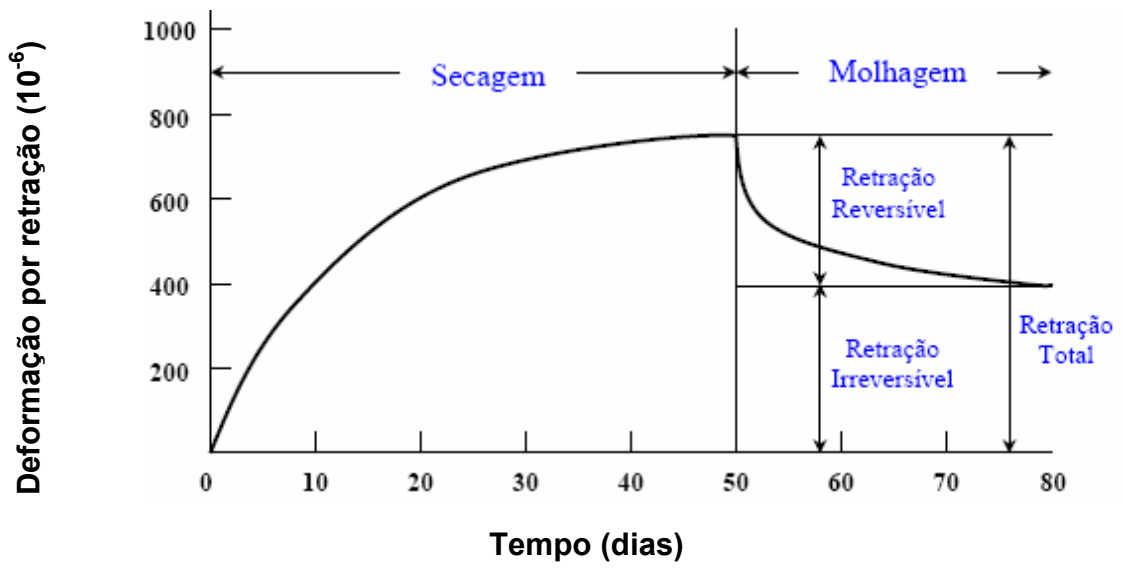

Gráfico 2.3 - Reversibilidade da retração por secagem (Fonte: MEHTA; MONTEIRO, 2008).
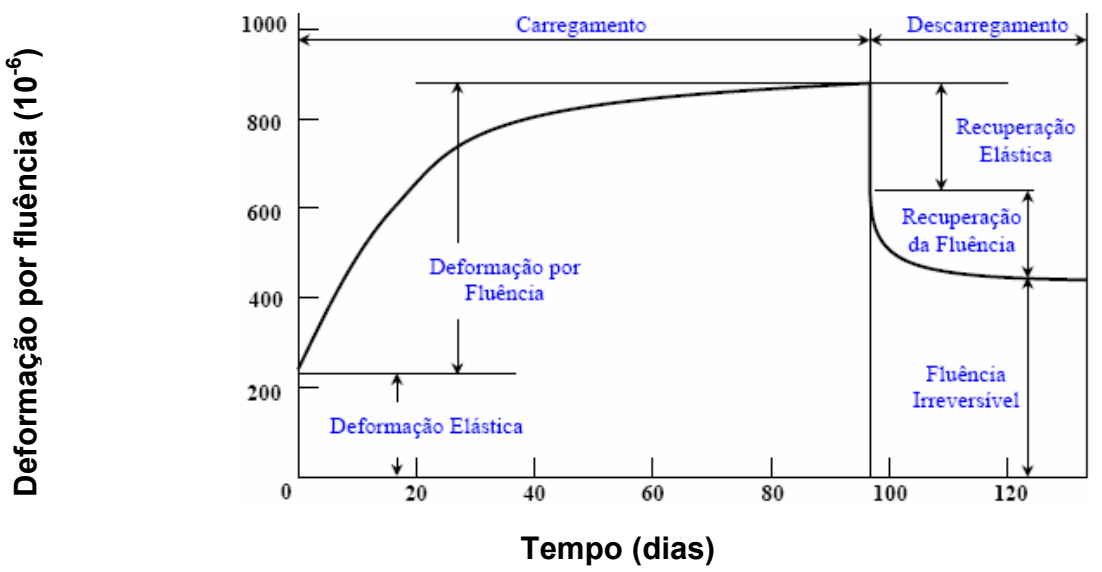

Gráfico 2.4 - Reversibilidade da fluência (Fonte: MEHTA; MONTEIRO, 2008).

A curva de fluência para o concreto sujeito a uma compressão uniaxial constante durante 91 dias e, após, descarregado é mostrado no gráfico 2.4.

Quando carregado, o concreto apresenta uma deformação elástica instantânea. Com a continuidade da aplicação da carga ao longo do tempo, as deformações aumentam. 
Quando é descarregado, a recuperação instantânea ou elástica é aproximadamente da mesma ordem da deformação elástica resultante da primeira aplicação de carga. A recuperação instantânea é seguida por uma redução gradual da deformação denominada recuperação da fluência. Embora a recuperação da fluência ocorra mais rapidamente que a fluência, a reversão da deformação por fluência não é total. Analogamente na retração por secagem, essa propriedade é definida pelos termos correspondentes, fluência reversível e irreversível.

\subsection{Fluência e retração do concreto}

Os movimentos da umidade na pasta de cimento hidratada, os quais essencialmente controlam a retração por secagem e as deformações por fluência no concreto são influenciadas por vários fatores. As inter-relações entre esses fatores são bastante complexas e não facilmente compreendidas (MEHTA; MONTEIRO, 2008). Neste item são discutidos as causas, efeitos e fatores que influenciam a fluência e a retração.

\subsubsection{Causas da fluência e retração por secagem}

Presume-se que tanto as deformações por retração por secagem quanto as de fluência do concreto sejam relativas, principalmente à remoção da água adsorvida da pasta de cimento. A diferença é que, para retração, a umidade diferencial relativa entre o concreto e o ambiente é a força motriz, enquanto que, para a fluência, é a tensão aplicada (MEHTA; MONTEIRO, 2008).

Uma pasta de cimento saturada não se manterá dimensionalmente estável quando exposta a umidades relativa do ambiente que estiverem abaixo da saturação, principalmente porque a perda de água fisicamente adsorvida do C-S-H resulta em deformação por retração. Além disso, uma causa menor da retração do sistema, ou como resultado de secagem ou de tensão aplicada, é a remoção da água mantida 
por tensão hidrostática em pequenos capilares $(<50 \mathrm{~nm})$ da pasta de cimento hidratada (MEHTA; MONTEIRO, 2008).

O fenômeno da retração deve ser estudado em três níveis: micro, médio e macro. Para que se possam compreender os mecanismos da retração do concreto, os níveis micro e médio devem ser abordados. O nível macro somente é estudado para análise dos fatores que influenciam na retração (NUNES, FIGUEIREDO, 2007).

As causas da fluência no concreto são mais complexas e ainda são controvertidas. A fluência ocorre na pasta de cimento carregada à tensão constante e está relacionada com a movimentação interna da água adsorvida, isto é, a percolação interna. Isso não quer dizer que não existam outras causas que contribuem para fluência do concreto, no entanto, a perda de água adsorvida sob pressão constante parece ser a causa mais importante. Deve ser lembrado que os poros capilares não permanecem preenchidos nem sob a pressão hidrostática, imersos em água. Assim, a percolação interna é possível em qualquer condição de conservação, fato que justifica a existência da fluência básica (MEHTA; MONTEIRO, 2008, NEVILLE, 1997 e RÜSCH, 1983).

Duas hipóteses são sugeridas por Neville (1997) na tentativa de explicar o fato do decréscimo nítido ao longo do tempo das deformações por fluência: ou esta diminuição é proporcional ao mecanismo de fluência, comprovando que a principal causa da fluência é a movimentação interna da água adsorvida; ou a espessura das camadas da água adsorvida, depois de muitos anos sob carga, possa ser reduzida a tal ponto que mais nenhuma redução seja possível sob a mesma tensão. Entretanto, foi observada fluência após 30 anos, fato que se opõe a segunda hipótese, levando a crer que a fluência seja devida a outras causas que a percolação da água adsorvida, como por exemplo, devido ao escoamento ou escorregamento viscoso entre as partículas de gel.

Além disso, Mehta e Monteiro (2008) sugerem outras causas, tais como: a não linearidade para nível de tensões maiores que 30 a $40 \%$ da tensão última; o micro fissuramento adicional da zona de transição devida à retração por secagem e/ou a resposta elástica atrasada do agregado, uma vez que ocorre a diminuição gradativa da tensão na pasta de cimento e a carga é transferida para o agregado, deformando-se elasticamente. 
Acker e Ulm (2000) afirmam que, analisando a fluência básica de pastas de cimento, há dois mecanismos que explicam a origem da fluência, ambos relacionados com a mobilidade da água. $\mathrm{O}$ primeiro mecanismo se dá no período de 10 dias (short-tem creep) e ocorre devido à mudança do equilíbrio hídrico que induz a movimentação da água em direção aos poros maiores, gerando deformações e tensões. O segundo mecanismo corresponde ao comportamento irreversível viscoso (long-term creep) e praticamente não ocorre alteração de volume. Bažant et al. (1997) sugeriram que o segundo mecanismo ocorra dentro da estrutura do CSH. É importante notar que o comportamento da fluência está largamente relacionado com a resposta viscoelástica do produto primário de hidratação e do produto final da pasta de cimento endurecida (CSH). Entretanto, as propriedades do CSH não foram medidas diretamente. Vandamme e UIm (2009) demonstraram que provavelmente a fluência ocorra devido ao rearranjo das partículas em nanoescala.

\subsubsection{Fatores que influenciam na fluência e retração por secagem}

A fluência e retração por secagem dependem de vários fatores relacionados entre si que proporciona uma abordagem complexa. Além disso, na interpretação de muitos dos fatores, surge uma dificuldade do fato de que na dosagem do concreto, não é possível alterar um dos fatores sem alterar também, pelo menos, mais um outro. Algumas características da fluência decorrem das propriedades intrínsecas das misturas, outras das condições externas (NEVILLE, 1997 e MEHTA; MONTEIRO, 2008).

A relevância em se fazer comentários sobre as propriedades que influenciam a deformação por fluência e retração vem do fato de que, tanto os modelos de fluência e retração estudados nesta pesquisa quanto o programa Diana levam em consideração estas propriedades no desenvolvimento de seus cálculos para o estudo da fluência. Como ambos serão utilizados para a elaboração desta pesquisa, achou-se de maneira fundamental o comentário destas propriedades. Neste item, são apresentados e discutidos os fatores que influenciam a fluência e retração por secagem. 


\subsubsection{MATERIAIS E DOSAGEM}

Segundo Mehta e Monteiro (2008) a granulometria, o tamanho máximo e a forma do agregado são fatores bastante significativos para a fluência e a retração por secagem no concreto.

$\mathrm{Na}$ retração, o agregado é o fator mais influente, restringindo a retração. O tamanho e a granulometria por si mesmo, não tem influência sobre a magnitude da retração, mas agregados maiores resultam no aumento do teor de agregado no volume total do concreto e, portanto, menor retração. De modo semelhante para uma mesma resistência com agregado do mesmo tamanho, um concreto com trabalhabilidade baixa contém mais agregado e menor retração do que outro com trabalhabilidade alta. Além disso, as propriedades elásticas do agregado determinam o grau de contenção, por exemplo, os agregados naturais comuns não apresentam retração; dolenitos e basaltos apresentam retração; agregados leves, de um modo geral, resultam em maior retração (NEVILLE, 1997).

Para concretos com baixa relação água cimento a maior parte das deformações é devida à retração autógena do que a retração por secagem. Nos concretos com baixa relação água cimento ou alto teor em quantidade ou substituição por escória de alto-forno (concreto de alta resistência, concreto auto adensável e concreto massa convencional) deve ser dado atenção especial para a retração autógena (TAZAWA; MIYAZAWA, 1993). Entretanto, o uso de adições pode provocar tanto o aumento da retração autógena, bem como da retração por secagem (NUNES; FIGUEIREDO, 2007).

Para a fluência, segundo Neville (1997), o aumento do teor de agregado de $65 \%$ para $75 \%$ pode reduzir a fluência em $10 \%$. O módulo de elasticidade do agregado é a propriedade física que mais influencia na fluência do concreto. Quanto maior o módulo menor a fluência. Outra propriedade seria a porosidade do agregado. Agregados com grande porosidade têm módulo de elasticidade baixo, embora agregados porosos desempenhem uma função direta nas trocas de umidade no interior do concreto, explicando a elevada fluência inicial em concretos que usam agregados leves secos. Concreto com agregado de arenito mostrou fluência mais que duas vezes maior do que outro com agregado de calcário. A fluência de um concreto com agregado leve com qualidade estrutural é aproximadamente igual a 
dos concretos com agregado normal. Uma fluência maior dos concretos com agregados leves é apenas um reflexo do menor módulo de elasticidade desses agregados. Além disso, a velocidade da fluência de concretos com agregados leves diminui com o tempo menos lentamente que no caso dos agregados normais; como a deformação elástica de concretos com agregados leves é geralmente maior do que a dos concretos normais, a relação entre a fluência e a deformação elástica é menor no caso dos concretos com agregados leves.

Estudos realizados por Troxell et al. apud Mehta; Monteiro (2008) mostraram que concretos com mesmo traço apresentam deformações por fluência e retração por secagem diferentes, dependendo do tipo de agregado utilizado. De modo geral, concretos contendo agregados de maior módulo de deformação apresentam menor fluência e menor retração como pode ser visto nos gráficos 2.5 a e b.

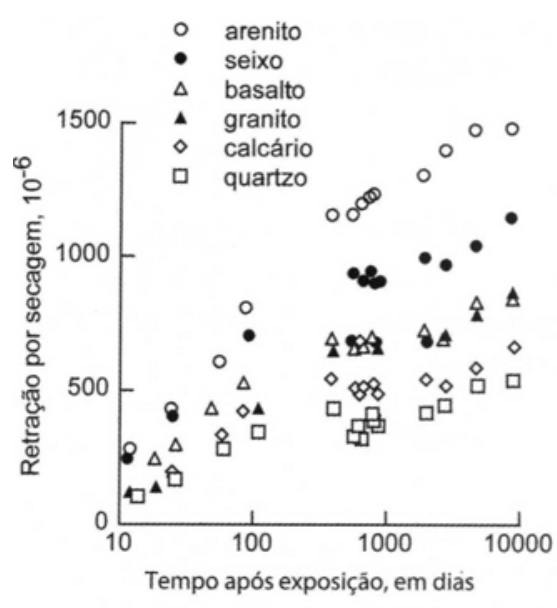

a) Retração.

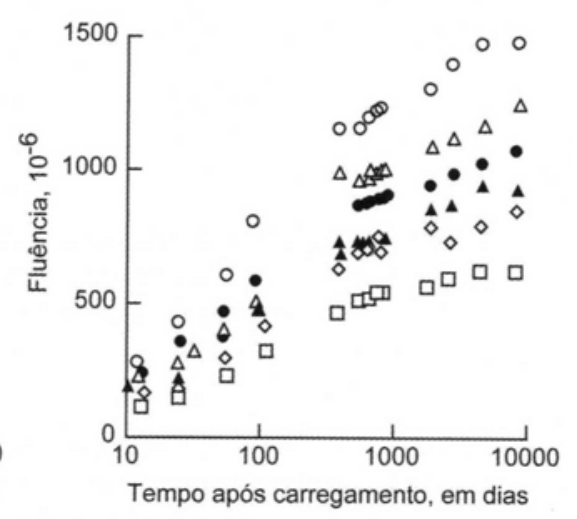

b) Fluência.

Gráfico 2.5 - Influência do tipo de agregado na retração por secagem e na fluência. (Fonte: TROXELL et al. apud METHA; MONTEIRO, 2008).

De acordo com Mehta e Monteiro (2008), a influência do consumo de cimento e da relação água cimento do concreto sobre a retração por secagem e a fluência não é direta, pois um aumento no volume de pasta de cimento significa uma diminuição da fração do agregado e, portanto, um aumento correspondente nas deformações dependentes de umidade no concreto. Para um dado consumo de cimento e crescente relação água cimento aumenta a retração por secagem e a fluência devido ao aumento da permeabilidade e diminuição da resistência, respectivamente. $\mathrm{O}$ aumento do consumo de cimento é diretamente proporcional à retração e a fluência, para uma dada relação água cimento, devido ao aumento de pasta. 
De acordo com Tazawa e Miyazawa (1993), para concretos e pastas com baixa relação água cimento, a retração autógena é maior. Além disso, concluiu que para pastas e concretos com relação água aglomerante entre 0,3 e 0,4 a retração por secagem é muito maior que a retração autógena, enquanto que para relação água aglomerante de 0,17 praticamente não há diferença entre ambas as retração autógena e por secagem.

Com relação à retração por secagem, Neville (1997) explica que, retração da pasta de cimento hidratada é diretamente proporcional à água cimento entre valores 0,2 e 0,6. Para valores maiores que 0,6 a água excedente pode ser removida por secagem sem retração. Em concretos com mesma trabalhabilidade, ou seja, mesmo teor de água, a retração não é alterada pelo aumento do teor de cimento. $O$ mesmo resultado foi observado por Kalintzis (2000).

\subsubsection{TENSÃO E RESISTÊNCIA}

De acordo com Neville (1997) existe uma proporcionalidade direta entre a fluência e a tensão aplicada, exceção feita para elementos carregados a idades muito pequenas. Essa proporção, para o concreto, está usualmente entre 0,4 e 0,6, da carga de ruptura, mas ocasionalmente pode atingir valores tão baixos como 0,3 , ou altos como 0,75 . Este último se aplica a concretos de alta resistência. Mehta e Monteiro (2008) e Neville (1997) afirmam que esta proporcionalidade é válida desde que a tensão aplicada esteja na faixa linear da relação tensão deformação, ou seja, até 0,4 .

Acima do limite de proporcionalidade, a fluência aumenta com o aumento da tensão a uma razão crescente e existe uma relação tensão resistência acima da qual a fluência produz a ruptura por fluência. Essa relação tensão resistência está no intervalo de 0,80 e 0,90 da resistência a curto prazo. A fluência aumenta a deformação total até que seja atingido um valor limite que corresponde à deformação admissível máxima para o concreto dado. Essa afirmativa implica um conceito de ruptura baseado na deformação limite, pelo menos na pasta de cimento hidratada endurecida. 
De acordo com Muller e Pristl (1993), em ambientes com temperatura constante e umidade relativa cíclica, há não linearidade da fluência para os níveis de tensões de 0,25 e 0,5 .

A resistência à compressão do concreto afeta consideravelmente a fluência. A fluência é inversamente proporcional à resistência do concreto no momento da aplicação da carga (MEHTA; MONTEIRO, 2008). Quando a resistência do concreto é aumentada a fluência decresce, pois, para aumentar à resistência do concreto, a quantidade de água utilizada tem que ser reduzida (HOWELLS; LARK; BARR, 2005).

\subsubsection{PROPRIEDADES DO CIMENTO}

Muitos pesquisadores observaram que mudanças normais na finura ou composição do cimento têm efeito insignificante sobre a retração do concreto. Entretanto, como o tipo de cimento influencia a resistência do concreto na aplicação da carga, a fluência é afetada, Mehta e Monteiro (2008). Por esse motivo, qualquer comparação de concretos feitos com diferentes tipos de cimento deveria levar em conta a influência do tipo de cimento sobre a resistência no momento da aplicação da carga, Neville (1997). Quando carregado nas primeiras idades, o concreto que utiliza cimento Portland comum apresenta fluência maior do que o concreto correspondente que contenha cimento de alta resistência inicial. Em virtude de sua baixa resistência inicial, misturas de concreto feitas com cimento de escória apresentam maior fluência em idade inicial (MEHTA; MONTEIRO, 2008).

Em estudos feitos por Neville (1997), cimentos extremamente finos, com área específica de até $740 \mathrm{~m}^{2} / \mathrm{kg}$ apresentam uma fluência inicial maior, mas depois de carregados durante um ou dois anos, uma fluência menor. Isso talvez se deva ao aumento rápido de resistência do cimento mais fino resultando em uma redução da relação tensão resistência efetiva.

Neville (1997) afirma que para uma tensão constante a uma mesma idade inicial, a fluência aumenta para os cimentos na ordem: alta resistência inicial, comum e de baixo calor de hidratação. 
A composição e a finura do cimento que influenciam a retração da pasta de cimento não têm efeito significativo sobre a retração do concreto. Cimentos finos não aumentam a retração do concreto, embora seja aumentada a retração de pastas de cimento. Não se acredita que a composição química do cimento tenha influência na retração, exceto nos casos dos cimentos com deficiência de gesso. A adição de cinzas volantes e escória de alto-forno aumentam a retração. A retração do concreto feito com cimento aluminoso é da mesma ordem de grandeza dos concretos de cimento Portland (MEHTA; MONTEIRO, 2008; NEVILLE, 1997).

Mehta e Monteiro (2008) afirmam que o cloreto de cálcio, escória granulada e pozolanas tendem a aumentar o volume de poros finos no produto de hidratação do cimento e, portanto, aumentam a retração por secagem e fluência. Mello Neto; Cincotto e Repette (2007) também verificaram maior retração para pastas e argamassas com escória.

Neville (1997) afirma que se pode dizer com confiança que o modelo da evolução da fluência e da recuperação não é alterado pela presença de cinza volante Classe C ou Classe F, escória granulada de alto-forno ou sílica ativa, ou mesmo uma combinação desses materiais. No entanto, pode haver algum efeito da pasta de cimento sobre a fluência resultante da inclusão de vários materiais cimentícios. $O$ efeito sobre a fluência por secagem, onde são importantes à permeabilidade e a difusividade da pasta de cimento hidratado, pode ser diferente do efeito sobre a fluência básica. Por exemplo, o uso da escória de alto-forno pode levar a uma fluência básica menor, porém com aumento da fluência por secagem.

Deve ser lembrado que os diferentes materiais cimentícios têm diferentes velocidades de reação e, portanto, aumento de resistências diferentes enquanto o concreto estiver sob carga.

\subsubsection{ADITIVOS}

Aditivos redutores de água e retardadores de pega, que são capazes de causar uma melhor dispersão de partículas de cimento anidro na água, também levam a um refinamento dos poros no produto de hidratação. Em geral, espera-se que 
aditivos que aumentem a retração por secagem e a fluência (MEHTA; MONTEIRO; 2008).

Neville (1997) afirma que aditivos redutores de água causam pequeno aumento na retração. O principal efeito é indireto, pois o uso de aditivo modifica o teor de água e/ou de cimento, influenciando na retração. Os superplastificantes aumentam a retração em 10 a 20\%, embora Al-Sleh e Al-Zaid (2004) tenham verificado que o plastificante utilizado não afetou a retração. Além disso, Neville (1997) afirma que aditivos redutores de água e retardadores podem aumentar a fluência básica. Existem indicações de que os aditivos à base de lignossulfonato resultam em fluência maior do que aqueles à base de ácidos carboxílicos. Entretanto, não há um modelo confiável do efeito desses aditivos sobre a fluência ou secagem. A mesma situação existe com relação aos superplastificantes.

\subsubsection{UMIDADE RELATIVA DO AMBIENTE E TEMPERATURA}

Neville (1997) afirma que um dos fatores mais importantes que atuam sobre a fluência e retração do concreto é a umidade relativa do ar que envolve o concreto. Para a fluência, quanto menor a umidade relativa maior a fluência (figura 2.6). Entretanto, a influência da umidade relativa é muito menor, ou nenhuma, no caso de elementos que tenham atingido equilíbrio higroscópico com o meio antes da aplicação da carga, ou seja, não é a umidade relativa que tem efeito sobre a fluência, mas o processo de secagem. Para a retração, ocorre o mesmo fenômeno, quanto maior a umidade menor a retração (figura 2.7).

Muller e Pristl (1993) concluíram que, para temperatura constante, as deformações por fluência em corpos de prova foram aceleradas em ambientes com umidade relativa cíclica, demonstrando um aumento de $20 \%$ em relação à exposição do concreto a umidade relativa média constante. Entretanto, Sakata e Ayano (2000) afirmam que a variação do coeficiente de fluência devido a condições cíclicas de umidade relativa é pequena e é possível expressar este coeficiente em função da média da umidade relativa. 


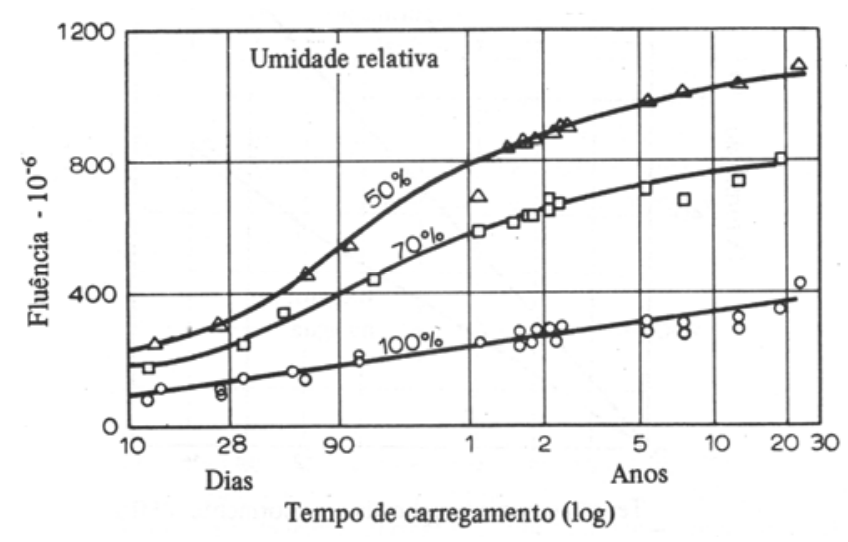

Gráfico 2.6 - Fluência em concretos carregados a 28 dias e mantidos em diferentes umidades relativas (Fonte: NEVILLE, 1997).

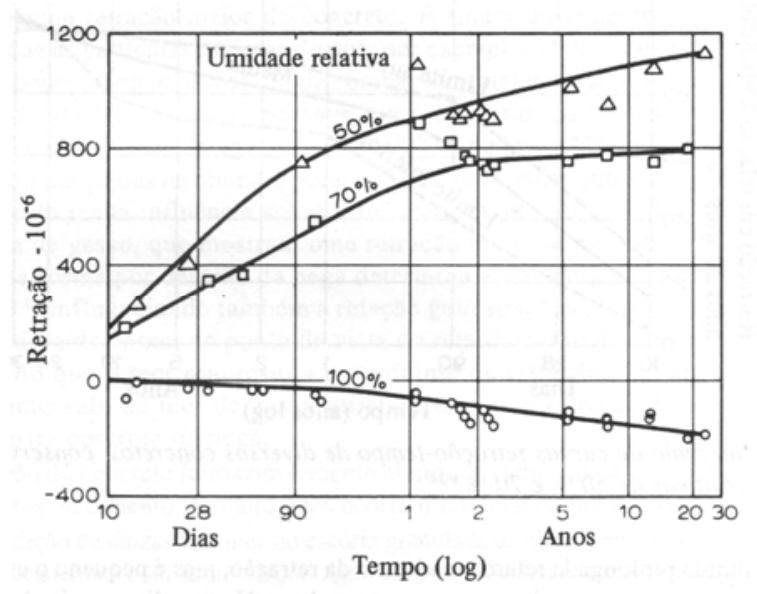

Gráfico 2.7 - Retração em concretos mantidos em diferentes umidades relativas (Fonte: NEVILLE, 1997).

Para a retração, Muller e Pristl (1993) verificaram que a umidade relativa não teve grande influência em ambientes cíclicos de umidade. Foi observada uma redução mínima nas deformações em ambientes cíclicos, provavelmente devida à exposição inicial do concreto a umidade relativa de $90 \%$.

Conforme Sakata e Ayano (2000) a influência do histórico de temperatura na deformação por retração no concreto é muito maior do que a variação de umidade relativa. Além disso, concluiu que, na faixa de temperatura de 5 a $30^{\circ} \mathrm{C}$, a relação entre a temperatura ambiente e deformação por retração é praticamente linear.

Mehta e Monteiro (2008) relatam que se uma peça de concreto é exposta a uma temperatura maior que a ambiente como parte do processo de cura antes de ser carregada, a resistência aumentará e a deformação por fluência será um tanto menor do que de um concreto armazenado a uma temperatura mais baixa. Por outro lado, a exposição à alta temperatura, durante o período em que o concreto está sendo carregado, pode aumentar a fluência.

Para temperaturas abaixo $5^{\circ} \mathrm{C}$, a deformação lenta praticamente cessa. Por outro lado, para temperaturas acima de $20^{\circ} \mathrm{C}$ a fluência aumenta. Esse fato é notado principalmente em pontes, nas quais o concreto do tabuleiro, sobre o qual existe uma camada de asfalto, atinge temperaturas acima de $40^{\circ} \mathrm{C}$ quando exposto à radiação solar durante um tempo longo (EQUIPE DE FURNAS, 1997). 


\subsubsection{GEOMETRIA DO ELEMENTO}

A espessura de uma peça de concreto tem grande influência no valor e na variação da fluência e retração. As peças espessas apresentam um menor valor de fluência em comparação com as delgadas, isso se deve ao fato de que a secagem no interior é mais demorada do que na parte externa da peça. Á uma umidade relativa mantida constante, tanto a forma quanto o tamanho da peça influenciam diretamente na magnitude da fluência (EQUIPE DE FURNAS, 1997).

De acordo com Neville (1997) foi observado que a fluência diminui com o aumento das dimensões do elemento, devido aos efeitos da retração e da fluência por secagem.

Devido à resistência ao transporte de água do interior do concreto para a atmosfera, a taxa de perda de água seria controlada, obviamente, pelo comprimento do caminho percorrido pela água, que está sendo expelida durante a retração por secagem e/ou fluência. A uma umidade relativa, o tamanho e a forma da peça de concreto determinam a magnitude da retração por secagem e de fluência. É conveniente expressar os parâmetros de tamanhos e formas por uma única quantidade, em termos de espessura teórica ou efetiva, que é igual à área da seção dividida pelo semiperímetro em contato com a atmosfera. O CEB-FIP Model Code (1990) apresenta a relação entre os coeficientes de fluência e retração por secagem e a espessura teórica para diferentes condições de umidade relativa, como pode ser visto nos gráficos 2.8 e 2.9 (MEHTA; MONTEIRO, 2008), onde $h_{0}$ é a espessura teórica da peça de concreto.

Entretanto, em estudos realizados por Videla; Covarrubias e Masana (2004) há a constatação de que a retração última parece ser independente das dimensões dos corpos de prova.

Fintel e Khan (1969) e Hansen e Mattock (1966) afirmam que a fluência é afetada pela geometria da peça somente quando o concreto não está selado. Além disso, de acordo com suas pesquisas experimentais, a fluência por secagem tem efeito preponderante da geometria durante apenas os três primeiros meses. Após este período a taxa de crescimento é igual à fluência básica. Hansen e Mattock (1966) consideram que a relação volume superfície (V/S) é um parâmetro que pode ser utilizado para previsão tanto da fluência quanto da retração para levar em 
consideração a geometria da peça. Pickett (1946) também afirma que comparando diversos elementos com V/S iguais há semelhança nas deformações por retração. Os modelos de previsão de fluência e retração do ACI209R (2008), Bažant e Baweja (2000) e Gardner e Lockman (2001) consideram a geometria do elemento pela relação V/S. Nos modelos do Eurocode 2 (2003) e NBR6118 (2004) a previsão é feita pela relação da área da seção transversal pelo perímetro da seção transversal $\left(A_{d} / u\right)$.

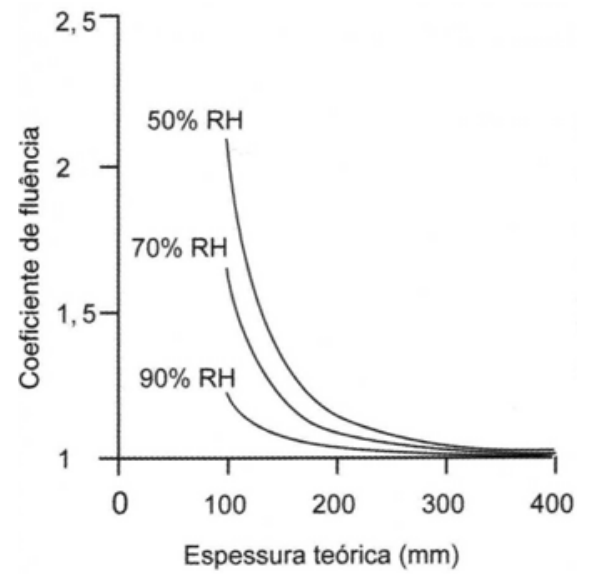

Gráfico 2.8 - Influência do tamanho da peça e da umidade relativa no coeficiente de fluência (Fonte: MEHTA; MONTEIRO, 2008).

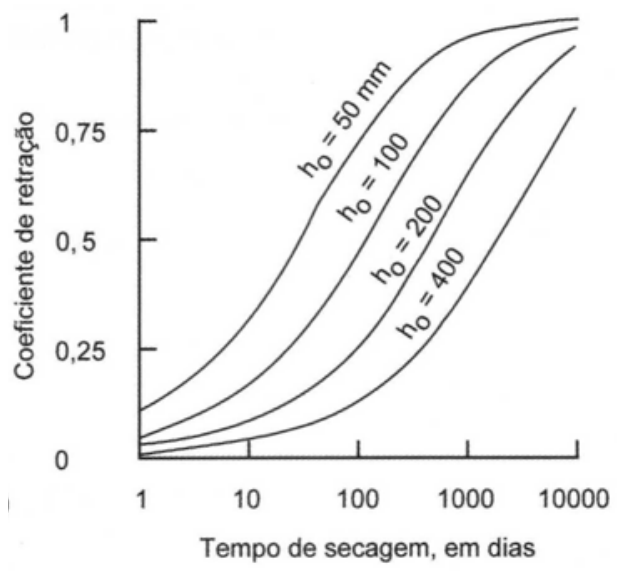

Gráfico 2.9 - Influência do tempo de exposição e tamanho da peça sobre o coeficiente de retração por secagem (Fonte: MEHTA; MONTEIRO, 2008).

\subsubsection{IDADE DE CARREGAMENTO}

A fluência dos concretos carregados a baixas idades é maior nas primeiras semanas de carregamento em relação a concretos carregados a maiores idades. Esse comportamento é devido ao maior grau de hidratação dos concretos mais velhos, que apresentam estrutura interna mais compacta e menos água disponível (KALINTZIS, 2000). 


\subsubsection{FATORES ADICIONAIS}

Outros fatores que também podem influenciar na fluência e retração por secagem são: condições de cura e tipo das tensões aplicadas (carga estática ou carregamento cíclico).

Dependendo das condições de cura de um elemento de concreto, as deformações por fluência podem ser, na prática, significantemente diferentes daquelas obtidas em um teste de laboratório realizado sob umidade relativa constante. Por exemplo, ciclos de secagem podem intensificar a microfissuração na zona de transição, aumentando assim a fluência. Pela mesma razão, tem-se observado com freqüência que a alternância da umidade relativa entre dois limites resultaria em uma maior fluência do que aquela obtida a uma umidade relativa constante, dentro daqueles limites (MEHTA; MONTEIRO, 2008).

Neville (1997) afirma que a cura úmida prolongada retarda a retração, mas é pequeno o efeito sobre a intensidade. Em geral, a duração do período de cura não é um fator importante para a retração.

De acordo com Neville (1997) grande parte dos resultados de fluência foi obtida sob cargas mantidas constantes, mas, muitas vezes, as cargas reais variam entre certos limites. Foi observada uma carga alternada, com um valor médio de relação tensão resistência, resulta uma deformação em função do tempo maior do que uma carga estática correspondente ao mesmo valor dessa relação. Aparentemente o carregamento cíclico resulta uma velocidade de fluência maior às primeiras idades e também leva a maiores valores a longo prazo. Os valores estáticos podem subestimar os valores quando a carga é cíclica.

\subsubsection{Efeitos da fluência e retração por secagem}

A fluência tem efeitos sobre as deformações e deflexões e muitas vezes também sobre a redistribuição de tensões, mas esses efeitos vaiam com o tipo de estrutura. A fluência não tem efeito direto sobre a resistência dos elementos estruturais, 
embora sob tensões muito altas acelere a aproximação da deformação limite à qual ocorre a ruptura (carga de 85 a 90\% da resistência última) (NEVILLE, 1997).

Um dos efeitos benéficos da fluência é o alívio de concentrações de tensões induzidas pela retração, por variações térmicas ou por movimentação das fundações. Em todas as estruturas de concreto, a fluência reduz as tensões internas devidas à retração não uniforme, de modo que resulta uma redução da fissuração (NEVILLE, 1997).

Apesar deste efeito benéfico, na maioria das vezes, o interesse dos engenheiros na fluência e retração está na deflexão e/ou deformações em elementos estruturais e perda de tensão em peças protendidas.

Em concreto massa, a fluência pode ser causa da fissuração devido a um ciclo de variações térmicas, ou seja, desprendimento do calor de hidratação e resfriamento subseqüente. Dessa forma, uma baixa tensão de compressão é induzida pela elevação rápida da temperatura no interior da massa de concreto. Essa tensão é baixa, pois o módulo de elasticidade do concreto muito novo é pequeno. Conseqüentemente, a resistência deste concreto também é baixa, de modo que a sua fluência é alta, aliviando a tensão de compressão. A compressão restante desaparece logo que se inicia o resfriamento. Com o prosseguimento do resfriamento do concreto, desenvolvem-se tensões de tração e, como a velocidade da fluência foi diminuída com a idade, pode haver fissuração antes que a temperatura atinja o valor inicial (lançamento do concreto). Por esse motivo, deve ser controlada a temperatura no interior de uma grande massa de concreto (NEVILLE, 1997).

Em pilares, a fluência resulta em uma transferência gradativa de carregamento do concreto para a armadura. No entanto, em pilares carregados excentricamente, a fluência aumenta a deflexão e pode levar à flambagem (NEVILLE, 1997). No item 2.4, estão discutidos detalhadamente o efeito da fluência e retração em pilares, um dos objetivos desta pesquisa. Além disso, a fluência e retração podem gerar problemas de encurtamento diferencial entre pilares e viga parede (CARREIRA; BURG, 2000).

Em concreto protendido, a fluência provoca a perda de protensão, gerando tensões mais baixas em idades mais avançadas. A fluência também pode levar deflexões excessivas de elementos estruturais e causar problemas de utilização, 
principalmente em edifícios de grande altura e pontes muito longas (NEVILLE, 1997).

\subsection{Modelos para previsão da fluência e retração}

Segundo Bažant e Baweja (2000) é muito difícil à previsão realística da fluência e retração do concreto por serem resultados da interação de diversos mecanismos físicos e serem influenciados por muitos parâmetros.

Desde 1982, diversos modelos foram propostos para a previsão da fluência e retração. Dentre os modelos, os mais estudados são: $A C l 209 R$ (2008) - $A C l$, Eurocode 2 (2003) - EC2, Bažant e Baweja (2000) - B3, Gardner e Lockman (2001) - GL e NBR6118 (2004) - NBR. Estes modelos apresentam complexidade e quantidade de dados de entrada (propriedades do concreto fresco e endurecido, condições ambientais, dimensões dos corpos de prova e condições de carregamento) distintos, conforme tabela 2.3. É pressuposto que quanto maior a quantidade dados de entrada nos modelos, melhor a aproximação destes com os resultados experimentais.

Além disso, cada modelo possui restrições de utilização que devem ser respeitadas a fim de obter resultados válidos. Na tabela 2.2 são apresentadas às limitações dos modelos.

Tabela 2.2 - Limitações dos modelos de fluência e retração.

\begin{tabular}{cccccc}
\hline Dados & $\mathrm{ACl}$ & $\mathrm{EC2}$ & $\mathrm{B} 3$ & $\mathrm{GL}$ & NBR \\
\hline $\mathrm{f}_{\mathrm{cm} 28}(\mathrm{MPa})$ & - & 20 a 90 & 17 a 70 & 0 a 70 & - \\
\hline $\mathrm{f}_{\mathrm{ck}}(\mathrm{MPa})$ & - & - & - & - & 20 a 50 \\
agregado/cimento & - & - & 2,5 a 13,5 & - & - \\
tensão aplicada $(\%)$ & $0-40$ & $0-45$ & $0-45$ & $0-40$ & $0-40$ \\
consumo de cimento $\left(\mathrm{kg} / \mathrm{m}^{3}\right)$ & - & - & $160-720$ & - & 300 a - \\
água/cimento & - & - & $0,35-0,85$ & $0,4-0,6$ & - \\
umidade relativa (\%) & 40 a 100 & 40 a 100 & 40 a 100 & 40 a 100 & 40 a 100 \\
tempo cura úmida (dias) & $>7$ & $<14$ & - & $>2$ & - \\
\hline
\end{tabular}


Tabela 2.3 - Parâmetros de entrada dos modelos de fluência e retração.

\begin{tabular}{|c|c|c|c|c|c|c|c|c|c|c|}
\hline \multirow{2}{*}{ Parâmetros } & \multicolumn{2}{|c|}{$\mathrm{ACl}$} & \multicolumn{2}{|c|}{ EC2 } & \multicolumn{2}{|c|}{ B3 } & \multicolumn{2}{|c|}{ GL } & \multicolumn{2}{|c|}{ NBR } \\
\hline & $\mathrm{F}^{*}$ & $\mathrm{R}^{*}$ & $\mathrm{~F}^{*}$ & $\mathrm{R}^{*}$ & $\mathrm{~F}^{*}$ & $\mathrm{R}^{*}$ & $\mathrm{~F}^{*}$ & $\mathrm{R}^{*}$ & $\mathrm{~F}^{*}$ & $\mathrm{R}^{*}$ \\
\hline Tipo cimento & $\sqrt{ }$ & & $\sqrt{ }$ & $\sqrt{ }$ & $\sqrt{ }$ & $\sqrt{ }$ & $\sqrt{ }$ & $\sqrt{ }$ & $\sqrt{ }$ & \\
\hline Umidade relativa (\%) & $\sqrt{ }$ & $\sqrt{ }$ & $\sqrt{ }$ & $\sqrt{ }$ & $\sqrt{ }$ & $\sqrt{ }$ & $\sqrt{ }$ & $\sqrt{ }$ & $\sqrt{ }$ & $\sqrt{ }$ \\
\hline Idade carregamento/fim cura (dias) & $\sqrt{ }$ & $\sqrt{ }$ & $\sqrt{ }$ & $\sqrt{ }$ & $\sqrt{ }$ & $\sqrt{ }$ & $\sqrt{ }$ & $\sqrt{ }$ & $\sqrt{ }$ & $\sqrt{ }$ \\
\hline Método de cura & $\sqrt{ }$ & $\sqrt{ }$ & & & $\sqrt{ }$ & $\sqrt{ }$ & & & & \\
\hline volume/superfície & $\sqrt{ }$ & $\sqrt{ }$ & & & $\sqrt{ }$ & $\sqrt{ }$ & $\sqrt{ }$ & $\sqrt{ }$ & & \\
\hline área/perímetro & & & $\sqrt{ }$ & $\sqrt{ }$ & & & & & $\sqrt{ }$ & $\sqrt{ }$ \\
\hline Dimensões do CP (cm) & $\sqrt{ }$ & $\sqrt{ }$ & $\sqrt{ }$ & $\sqrt{ }$ & $\sqrt{ }$ & $\sqrt{ }$ & $\sqrt{ }$ & $\sqrt{ }$ & $\sqrt{ }$ & $\sqrt{ }$ \\
\hline Secagem antes carregamento (dias) & & & & $\sqrt{ }$ & $\sqrt{ }$ & & $\sqrt{ }$ & $\sqrt{ }$ & & \\
\hline $\mathrm{f}_{\mathrm{cmt0}}(\mathrm{MPa})$ & $\sqrt{ }$ & & $\sqrt{ }$ & & & & $\sqrt{ }$ & & $\sqrt{ }$ & \\
\hline $\mathrm{f}_{\mathrm{ck}}(\mathrm{MPa})$ & & & & $\sqrt{ }$ & & & & & & \\
\hline $\mathrm{f}_{\mathrm{cm} 28}(\mathrm{MPa})$ & $\sqrt{ }$ & & $\sqrt{ }$ & $\sqrt{ }$ & $\sqrt{ }$ & $\sqrt{ }$ & $\sqrt{ }$ & $\sqrt{ }$ & $\sqrt{ }$ & \\
\hline $\mathrm{E}_{\mathrm{cmt0}}(\mathrm{MPa})$ & $\sqrt{ }$ & & $\sqrt{ }$ & & $\sqrt{ }$ & & $\sqrt{ }$ & & $\sqrt{ }$ & \\
\hline $\mathrm{E}_{\mathrm{cm} 28}(\mathrm{MPa})$ & $\sqrt{ }$ & & $\sqrt{ }$ & & $\sqrt{ }$ & $\sqrt{ }$ & $\sqrt{ }$ & & $\sqrt{ }$ & \\
\hline Resistência agregado & & & $\sqrt{ }$ & & & & & & & \\
\hline Quantidade agregado total $\left(\mathrm{kg} / \mathrm{m}^{3}\right)$ & & & & & $\sqrt{ }$ & & & & & \\
\hline Consumo cimento $\left(\mathrm{kg} / \mathrm{m}^{3}\right)$ & & $\sqrt{ }$ & & & $\sqrt{ }$ & & & & & \\
\hline Quantidade água $\left(\mathrm{kg} / \mathrm{m}^{3}\right)$ & & & & & $\sqrt{ }$ & $\sqrt{ }$ & & & & \\
\hline Agregado miúdo (\%) & $\sqrt{ }$ & $\sqrt{ }$ & & & & & & & & \\
\hline Abatimento $(\mathrm{mm})$ & $\sqrt{ }$ & $\sqrt{ }$ & & & & & & & $\sqrt{ }$ & $\sqrt{ }$ \\
\hline Temperatura $\left({ }^{\circ} \mathrm{C}\right)$ & & & $\sqrt{ }$ & $\sqrt{ }$ & & & & & $\sqrt{ }$ & $\sqrt{ }$ \\
\hline Volume de ar (\%) & $\sqrt{ }$ & $\sqrt{ }$ & & & & & & & & \\
\hline Tipo de agregado & & & & & & & & & $\sqrt{ }$ & \\
\hline
\end{tabular}

${ }^{*} \mathrm{~F}$ - fluência, $\mathrm{R}$ - retração.

Neste item, são apresentados os modelos de fluência e retração do $A C I 209 R$ (2008) - ACl, Eurocode 2 (2003) - EC2, Bažant e Baweja (2000) - B3, Gardner e Lockman (2001) - GL e NBR6118 (2004) - NBR.

\subsubsection{ACI 209R (2008)}

Segundo o $\mathrm{ACl}$, para condições padrões, cura úmida e idade de carregamento de 7 dias, o coeficiente de fluência $\varphi\left(t, t_{0}\right)$ é definido pela eq.(2-1): 
$\varphi\left(t, t_{0}\right)=\frac{\left(t-t_{0}\right)^{0,6}}{10+\left(t-t_{0}\right)^{0,6}} \varphi\left(\infty, t_{0}\right)$

( $\left.t-t_{0}\right)$ - período de tempo desde a aplicação da carga (dias)

$\varphi\left(\infty, t_{0}\right)$ - coeficiente de fluência última dado pela eq.(2-2):

$\varphi\left(\infty, t_{0}\right)=2,35 \gamma_{c}$

$\gamma_{c}$ - fatores de correção para condições fora do padrão, dada pela eq.(2-3):

$\gamma_{c}=\gamma_{1 a} \cdot \gamma_{s} \cdot \gamma_{\psi} \cdot \gamma_{a r} \cdot \gamma_{U} \cdot \gamma_{h}$ ou $\gamma_{v s}$

Para idades de carregamento maiores que 7 dias e cura úmida do concreto, tem-se $\gamma_{l a}$ dada pela eq.(2-4):

$\gamma_{1 a}=1,25 t_{0}^{-0,118}$

Para concreto curado a vapor, tem-se $\gamma_{l a}$ dado pela eq.(2-5):

$\gamma_{1 a}=1,13 t_{0}^{-0,094}$

Os coeficientes $\gamma_{s}, \gamma_{\Psi}$ e $\gamma_{a r}$ são todos relacionados à composição do concreto e são definidos pelas eq.(2-6), eq.(2-7) e eq.(2-8):

$\gamma_{s}=0,82+0,00264 s$

$s$ - consistência do concreto pelo abatimento do tronco de cone $(\mathrm{mm})$

$\gamma_{\psi}=0,88+0,0024 \psi$

$\Psi$ - proporção de agregado miúdo no total de agregado em porcentagem de massa $(\%)$

$\gamma_{a r}=0,46+0,09 a r$

ar - teor de ar (\%)

O coeficiente $\gamma_{a r}$ não deve ser menor que 1. O coeficiente de umidade $\gamma_{U}$ é dado pela eq.(2-9):

$\gamma_{U}=1,27-0,0067 U \quad U>40$

$U$ - umidade relativa do ambiente (\%)

O coeficiente de espessura da peça pode ser calculado por dois métodos:

1. Método da espessura média

Para espessura média entre $150 \mathrm{~mm}$ e $380 \mathrm{~mm}$, tem-se eq.(2-10) e eq.(2-11):

$\gamma_{h}=1,14-0,023 h$, para $\left(t-t_{0}\right)<1$ ano

$\gamma_{h}=1,10-0,017 h$, para $\left(t-t_{0}\right)>1$ ano

$h$ - espessura média (mm) 
2. Método da relação volume superfície pela eq.(2-12):

$$
\gamma_{\text {vs }}=\frac{2}{3}\left[1+1,13 \exp \left(-\frac{0,0213 V}{S}\right)\right]
$$

$\frac{V}{S}$ - relação volume superfície $(\mathrm{mm})$

A deformação por retração após 7 dias para cura úmida é dada pela eq.(2-13):

$$
\varepsilon_{c s}\left(t, t_{s}\right)=\frac{t}{35+t} \varepsilon_{s \infty}\left(\infty, t_{s}\right)
$$

$t$ - idade do concreto após início da secagem (dias)

$\mathrm{t}_{\mathrm{s}}$ - idade do concreto no início da secagem (dias)

$\varepsilon_{s o \alpha}\left(\infty, t_{s}\right)$ - deformação por retração última dada pela eq.(2-14):

$\varepsilon_{s \infty}\left(t, t_{s}\right)=780 \gamma_{s h} \cdot 10^{-6}$

$\gamma_{s h}$ - fatores de correção para condições fora do padrão dado pela eq.(2-15):

$\gamma_{s h}=\gamma_{U} \cdot \gamma_{s} \cdot \gamma_{\psi} \cdot \gamma_{c} \cdot \gamma_{a r} \cdot \gamma_{h}$ ou $\gamma_{v s}$

Para cura úmida durante um período diferente de 7 dias utiliza tem-se $\gamma_{c p}$ dado pela tabela 2.4:

\begin{tabular}{cc} 
Tabela 2.4 - Fator de correção referente ao período de cura & \multicolumn{2}{c}{ Duração da cura úmida } & Coeficiente $\gamma_{\mathrm{cp}}$ \\
\hline 1 & 1,2 \\
3 & 1,1 \\
7 & 1,0 \\
14 & 0,93 \\
28 & 0,86 \\
90 & 0,75 \\
\hline
\end{tabular}

Para concreto exposto a diferentes umidades relativas ambientes, tem-se eq.(2-16) e eq.(2-17):

$$
\begin{aligned}
& \gamma_{U}=1,40-0,010 U, \text { para } 40 \leq U \leq 80 \\
& \gamma_{U}=3-0,030 U \text {, para } 80<U \leq 100 \\
& U \text { - umidade relativa (\%) }
\end{aligned}
$$

Os coeficientes $\gamma_{s}, \gamma_{\Psi}, \gamma_{a r}$ e $\gamma_{c}$ são todos relacionados à composição do concreto e são definidos pelas eq.(2-18), eq.(2-19), eq.(2-20), eq.(2-21) e eq.(2-22):

$$
\gamma_{s}=0,89+0,00161 s
$$


$s$ - consistência do concreto pelo abatimento do tronco de cone $(\mathrm{mm})$

$\gamma_{\psi}=0,30+0,014 \psi$, para $\Psi \leq 50 \%$

$\gamma_{\psi}=0,90+0,002 \psi$, para $\Psi>50 \%$

$\Psi$ - proporção de agregado miúdo no total de agregado em porcentagem de massa (\%)

$\gamma_{a r}=0,95+0,008 a r$

ar - teor de ar (\%)

$\gamma_{c}=0,75+0,00061 c$

$c$ - consumo de cimento $\left(\mathrm{kg} / \mathrm{m}^{3}\right)$

O coeficiente de espessura da peça pode ser calculado por dois métodos:

1. Método da espessura média

Para espessura média entre $150 \mathrm{~mm}$ e $380 \mathrm{~mm}$, têm-se as eq.(2-23) e eq.(2-24):

$\gamma_{h}=1,23-0,00015 h$, para $\left(\mathrm{t}, \mathrm{t}_{0}\right)<1$ ano

$\gamma_{h}=1,17-0,00114 h$, para $\left(\mathrm{t}, \mathrm{t}_{0}\right)>1$ ano

$h$ - espessura média $(\mathrm{mm})$

2. Método da relação volume superfície dada pela eq.(2-25).

$$
\gamma_{v s}=1,12 \exp (-0,00472 \mathrm{~V} / \mathrm{s})
$$

$\frac{V}{S}$ - relação volume superfície $(\mathrm{mm})$

O módulo de elasticidade para diferentes idades é dado pela eq.(2-26):

$E_{c m t}=33\left[w^{3} f_{c m j}\right]^{1 / 2}$

$f_{c m j}$ - resistência média à compressão no tempo $\mathrm{t}(\mathrm{MPa})$

$w$ - peso unitário do concreto $\left(\mathrm{kg} / \mathrm{m}^{3}\right)$

Para prever a resistência média à compressão em qualquer idade tem-se a eq.(2-27):

$$
f_{c m j}=\frac{t}{\alpha+\beta t} f_{c m 28}
$$

$f_{c m 28}-$ resistência à compressão média aos 28 dias $(\mathrm{MPa})$

$\alpha$ e $\beta$ - constantes dadas pela tabela 2.5: 
Tabela 2.5 - Constantes $\alpha$ e $\beta$.

\begin{tabular}{lccc}
\hline Tipo de cura & Tipo de cimento & \multicolumn{2}{c}{ Constantes $\alpha$ e $\beta$} \\
\hline Cura úmida & I & $\alpha=4,00$ & $\beta=0,85$ \\
& III & $\alpha=2,30$ & $\beta=0,92$ \\
Cura a vapor & I & $\alpha=1,00$ & $\beta=0,95$ \\
& III & $\alpha=0,70$ & $\beta=0,98$ \\
\hline
\end{tabular}

\subsubsection{Eurocode 2 (2003)}

O modelo de previsão de fluência do EC2 está restrito a tensões constantes de serviço, isto é, até $0,45 f_{c k}\left(t_{0}\right)$, para o qual a fluência é admitida ser linearmente dependente da tensão.

A deformação do concreto por fluência $\varepsilon_{c c}\left(\infty, t_{0}\right)$ no tempo infinito é dado pela eq.(2-28):

$\varepsilon_{c c}\left(\infty, t_{0}\right)=\varphi\left(\infty, t_{0}\right)\left(\frac{\sigma}{E_{c}}\right)$

$\varphi\left(\infty, t_{0}\right)$ - coeficiente de fluência no tempo infinito

$\sigma$ - tensão aplicada (MPa)

$E_{c}$ - módulo de elasticidade médio na idade considerada (MPa)

A seguir são apresentadas as expressões de previsão do coeficiente de fluência $\varphi\left(t, t_{0}\right)$ (eq.(2-29)), entre o tempo $t$ e $t_{0}$, em relação à deformação elástica aos 28 dias, do modelo adotado pelo EC2.

$\varphi\left(t, t_{0}\right)=\varphi_{0} \beta_{c}\left(t, t_{0}\right)$

$\varphi_{0}$ - coeficiente de fluência fictício dado pela eq.(2-30):

$\varphi_{0}=\varphi_{R H} \beta\left(f_{c m}\right) \beta\left(t_{0}\right)$

$\varphi_{R H}$ - fator que considera a umidade relativa dados pelas eq.(2-31) e eq.(2-32):

$\varphi_{R H}=1+\frac{1-R H / 100}{0,1 \sqrt[3]{h_{0}}} \quad$ para $\mathrm{f}_{\mathrm{cm}} \leq 35 \mathrm{MPa}$ 
$\varphi_{R H}=\left[1+\frac{1-R H / 100}{0,1 \sqrt[3]{h_{0}}} \alpha_{1}\right] \alpha_{2} \quad$ para $\mathrm{f}_{\mathrm{cm}} \geq 35 \mathrm{MPa}$

$\mathrm{RH}$ - umidade relativa do meio ambiente (\%)

$\beta\left(f_{c m}\right)$ - fator que considera a resistência média à compressão do concreto dado pela eq.(2-33):

$\beta\left(f_{c m}\right)=\frac{16,8}{\sqrt{f_{c m}}}$

$f_{c m}$ - resistência média à compressão para 28 dias (MPa)

$\beta\left(t_{0}\right)$ - fator que considera o efeito da idade da aplicação de carga no concreto dado pela eq.(2-34):

$\beta\left(t_{0}\right)=\frac{1}{\left(0,1+t_{0, \alpha}^{0,20}\right)}$

$h_{0}$ - espessura fictícia do elemento de concreto $(\mathrm{mm})$ dado pela eq.(2-35):

$h_{0}=\frac{2 A_{c}}{u}$

$\beta_{c}\left(t, t_{0}\right)$ - coeficiente que define o desenvolvimento de fluência com o tempo dado pela eq.(2-36):

$\beta_{c}\left(t, t_{0}\right)=\left(\frac{t-t_{0}}{\beta_{H}+t-t_{0}}\right)$

$\beta_{H}$ - coeficiente que depende da umidade relativa (\%) e da espessura fictícia ( $\mathrm{mm}$ ) dados pelas eq.(2-37) e eq.(2-38):

$\beta_{H}=1,5\left(1+(0,012 R H)^{18}\right) h_{0}+250 \leq 1500$ para $\mathrm{f}_{\mathrm{cm}} \leq 35 \mathrm{MPa}$

$\beta_{H}=1,5\left(1+(0,012 R H)^{18}\right) h_{0}+250 \alpha_{3} \leq 1500 \alpha_{3}$ para $\mathrm{f}_{\mathrm{cm}} \geq 35 \mathrm{MPa}$

$\alpha_{1 / 2 / 3}$ - coeficientes para considerar a influência da resistência do concreto dados pelas eq.(2-39), eq.(2-40) e eq.(2-41):

$$
\begin{aligned}
& \alpha_{1}=\left[\frac{35}{f_{c m}}\right]^{0,7} \\
& \alpha_{2}=\left[\frac{35}{f_{c m}}\right]^{0,2} \\
& \alpha_{3}=\left[\frac{35}{f_{c m}}\right]^{0,5}
\end{aligned}
$$


$A_{c}$ - área da seção transversal da peça $\left(\mathrm{mm}^{2}\right)$

$u$ - perímetro externo da seção transversal em contato com o ar (mm)

O efeito do tipo de cimento no coeficiente de fluência do concreto pode ser levado em conta modificando a idade de carregamento $t_{0}$ dado pela eq.(2-42):

$t_{0}=t_{0, T}\left(\frac{9}{2+t_{0, T}^{1,2}}+1\right)^{\alpha} \geq 0,5$

$t_{0, T}$ - idade do concreto no carregamento ajustada com a temperatura (dias), de acordo com a eq.(2-43)

$\alpha$ - coeficiente dependente do tipo de cimento, igual a:

-1 para cimento classe $S$

0 para cimento classe $\mathrm{N}$

1 para cimento classe $R$

A idade fictícia do concreto considerando o efeito da temperatura dentro da faixa de 0 a $80^{\circ} \mathrm{C}$ na maturidade do concreto pode ser levada em conta de acordo com a eq.(2-43):

$t_{T}=\sum_{i=1}^{n} e^{-\left(4000 /\left[273+T\left(\Delta t_{i}\right)\right]-13,65\right)} \Delta t_{i}$

$t_{T}$ - idade do concreto ajustada com a temperatura e substitui $t$ nas equações correspondentes (dias)

$T\left(\Delta t_{i}\right)$ - temperatura média diária do ambiente $\left({ }^{\circ} \mathrm{C}\right)$

$\Delta t_{i}$ - período em que a temperatura média diária do ambiente se manteve constante (dias)

A deformação total por retração $\left(\varepsilon_{c S}\right)$ é composta por duas parcelas, deformação de retração por secagem $\left(\varepsilon_{c d}\right)$ e deformação de retração autógena $\left(\varepsilon_{c a}\right)$ dado pela eq.(2-44).

$\varepsilon_{c s}=\varepsilon_{c d}+\varepsilon_{c a}$

A deformação de retração por secagem $\left(\varepsilon_{c d}\right)$ é calculada pelas eq.(2-45), eq.(2-46), eq.(2-47) e eq.(2-48):

$\varepsilon_{c d}(t)=\beta_{d s}\left(t, t_{s}\right) k_{h} \varepsilon_{c d, 0}$ 


$$
\begin{aligned}
& \beta_{d s}\left(t, t_{s}\right)=\frac{\left(t-t_{s}\right)}{\left(t-t_{s}\right)+0,04 \sqrt{h_{0}^{3}}} \\
& \varepsilon_{c d, 0}=0,85\left[\left(220+110 \alpha_{d s 1}\right) \exp \left(-\alpha_{d s 2} \frac{f_{c m}}{f_{c m 0}}\right)\right] 10^{-6} \beta_{R H} \\
& \beta_{R H}=-1,55\left[1-\left(\frac{R H}{R H_{0}}\right)^{3}\right]
\end{aligned}
$$

$f_{c m}$ - resistência à compressão média aos 28 dias $(\mathrm{MPa})$

$f_{c m 0}-10 \mathrm{MPa}$

$t$ - idade do concreto (dias)

$t_{s}$ - idade do concreto no início da secagem (dias)

$h_{0}$ - espessura fictícia do elemento de concreto $(\mathrm{mm})$

$\alpha_{d s 1}$ - coeficiente que depende do tipo de cimento:

3 para o cimento classe $S$

4 para cimento classe $\mathrm{N}$

6 para cimento classe $R$

$\alpha_{d s 2}$ - coeficiente que depende do tipo de cimento:

0,13 para o cimento classe $S$

0,12 para cimento classe $\mathrm{N}$

0,11 para cimento classe $\mathrm{R}$

$\mathrm{RH}$ - umidade relativa do ambiente (\%)

$R H_{0}-100 \%$

$k_{h}$ - coeficiente dependente da espessura fictícia $h_{0}$ de acordo com a tabela 2.6

Tabela 2.6 - Valores de $k_{h}$ na equação.

\begin{tabular}{cc}
\hline $\mathrm{h}_{0}$ & $\mathrm{k}_{\mathrm{h}}$ \\
\hline 100 & 1,0 \\
200 & 0,85 \\
300 & 0,75 \\
$\geq 500$ & 0,70 \\
\hline
\end{tabular}

A deformação de retração autógena é dada pelas eq.(2-49), eq.(2-50) e eq.(2-51):

$\varepsilon_{c a}(t)=\beta_{a s}(t) \varepsilon_{c a}(\infty)$

$\varepsilon_{c a}(\infty)=2,5\left(f_{c k}-10\right) 10^{-6}$ 
$\beta_{\text {as }}(t)=1-\exp \left(-0,2 t^{0,5}\right)$

$t$ - idade do concreto (dias)

$f_{c k}$ - resistência característica à compressão do concreto aos 28 dias (MPa)

A resistência característica do concreto é dada pelas eq.(2-52) e eq.(2-53):

$f_{c k}=f_{c m}-8$ para $3<\mathrm{t}<28$ dias

$f_{c k}(t)=f_{c k}$ para $t \geq 28$ dias

A resistência à compressão média do concreto no tempo $t$ para temperatura média de $20^{\circ} \mathrm{C}$ para qualquer idade é dada pelas eq.(2-54) e eq.(2-55):

$f_{c m}(t)=\beta_{c c}(t) f_{c m}$

$\beta_{c c(t)}=\exp \left(s\left[1-\left(\frac{28}{t}\right)^{1 / 2}\right]\right)$

$f_{c k}(t)$ - resistência característica à compressão do concreto em $t$ dias (MPa)

$f_{c k}$ - resistência característica à compressão do concreto aos 28 dias (MPa)

$f_{c m}(t)$ - resistência média à compressão do concreto em $t$ dias (MPa)

$f_{c m}$ - resistência média à compressão do concreto a 28 dias (MPa)

$\beta_{c c}(t)$ - coeficiente que depende da idade do concreto $t$

$t$ - idade do concreto (dias)

$s$ - coeficiente que depende do tipo de cimento:

0,20 cimento classe CEM42,5R; CEM53,5N; e CEM53,5R (classe $R$ )

0,35 cimento classe CEM32,5R; CEM42,5N (classe $\mathrm{N}$ )

0,38 cimento classe CEM $32,5 \mathrm{~N}$ (classe $\mathrm{S}$ )

O módulo de elasticidade médio aos 28 dias para concretos com agregados de quartzo é dada pela eq.(2-56):

$E_{c m}=22\left[\frac{f_{c m}}{10}\right]^{0,3}$

$f_{c m}$ - resistência média à compressão a 28 dias $(\mathrm{MPa})$

Para agregados de calcário e arenitos o módulo de elasticidade deve ser reduzido de $10 \%$ e $30 \%$, respectivamente. Para agregados de basalto o valor deve ser acrescido de $20 \%$

A variação do módulo de elasticidade com o tempo é dada pela eq.(2-57): 
$E_{c m}(t)=\left(\frac{f_{c m}(t)}{f_{c m}}\right)^{0,3} E_{c m}$

$E_{c m}(t)$ - módulo de elasticidade no tempo $t(\mathrm{MPa})$

$E_{c m}$ - módulo de elasticidade aos 28 dias $(\mathrm{MPa})$

\subsubsection{Bažant e Baweja (2000)}

O presente modelo de previsão está restrito as tensões de serviço, da ordem de $0,45 f_{c}^{\prime}$ (resistência média à compressão), para a qual o comportamento da fluência é admitido como sendo linearmente dependente da tensão.

O modelo B3 de previsão de fluência apresentado por Bažant; Baweja (2000) expressa o efeito ao longo do tempo por meio da fluência específica $(J)$ conforme a eq.(2-58):

$J\left(t, t^{\prime}\right)=q_{1}+C_{0}\left(t, t^{\prime}\right)+C_{d}\left(t, t^{\prime}, t_{0}\right)$

$q_{1}$ - deformação instantânea devido à tensão unitária

$O$ coeficiente de fluência é dado pela eq.(2-59):

$\phi\left(t, t^{\prime}\right)=E\left(t^{\prime}\right) J\left(t, t^{\prime}\right)-1$

$C_{0}\left(t, t^{\prime}\right)$ - fluência específica básica, em 10-6/psi, dadas pelas eq.(2-60), eq.(2-61), eq.(2-62), eq.(2-63) e eq.(2-64):

$$
\begin{aligned}
& C_{0}\left(t, t^{\prime}\right)=q_{2} Q\left(t, t^{\prime}\right)+q_{3} \ln \left[1+\left(t-t^{\prime}\right)^{n}\right]+q_{4} \ln \left(\frac{t}{t^{\prime}}\right) \\
& Q\left(t, t^{\prime}\right)=Q_{f}\left(t^{\prime}\right)\left[1+\left(\frac{Q_{f}\left(t^{\prime}\right)}{Z\left(t, t^{\prime}\right)}\right)^{r\left(t^{\prime}\right)}\right]^{-1 / r\left(t^{\prime}\right)} \\
& r\left(t^{\prime}\right)=1,7\left(t^{\prime}\right)^{0,12}+8 \\
& Z\left(t, t^{\prime}\right)=\left(t^{\prime}\right)^{-m} \ln \left[1+\left(t-t^{\prime}\right)^{n}\right] \\
& Q_{f}\left(t^{\prime}\right)=\left[0,086\left(t^{\prime}\right)^{2 / 9}+1,21\left(t^{\prime}\right)^{4 / 9}\right]^{-1}
\end{aligned}
$$

$n$ e $m$ - coeficientes dependentes do tipo de material e iguais a 0,1 e 0,5 , respectivamente. 
$C_{d}\left(t, t^{\prime}, t_{0}\right)$ - fluência específica adicional devido à secagem (fluência por secagem) dada pela eq.(2-65):

$\left.C_{d}\left(t, t^{\prime}, t_{0}\right)=q_{5}[\exp \{-8 H(t)\}]-\exp \left\{-8 H\left(t^{\prime}\right)\right\}\right]^{1 / 2}$

$H(t)$ - média espacial da umidade relativa dos poros no interior da seção transversal dada pela eq.(2-66):

$H(t)=1-(1-h) S(t)$

$S(t)$ - função do tempo para a retração dada pela eq.(2-67):

$S(t)=\operatorname{tgh}\left(\frac{t-t_{0}}{\tau_{s h}}\right)^{1 / 2}$

$\tau_{s h}$ - retração ao meio tempo (dias) dadas pelas eq.(2-68) e eq.(2-69):

$\tau_{s h}=k_{t}\left(k_{s} D\right)^{2}$

$k_{t}=190,8 t_{0}^{-0,08} f_{c}^{-1 / 4}$

$D$ - espessura efetiva da seção transversal (polegadas), dada pela eq.(2-70):

$D=2 v / s$

$k_{h}$ - coeficiente dependente da umidade relativa ambiente (\%):

$1-h^{3}$ para $U \leq 0,98$

$-0,2$ para $\mathrm{h}=1$ (expansão em água)

Interpolar para $0,98 \leq \mathrm{h} \leq 1$

$k_{s}$ - coeficiente dependente da forma dada por:

1,00 para uma laje infinita

1,15 para um cilindro infinito

1,25 pra um prisma quadrado infinito

1,3 para uma esfera

1,35 para um cubo

$q_{1}, q_{2}, q_{3}, q_{4}$ e $q_{5}$ - coeficientes empíricos dados pelas eq.(2-71), eq.(2-72), eq.(2-73), eq.(2-74) e eq.(2-75), respectivamente.

$q_{1}=0,6 \cdot 10^{6} / E_{28}$

$q_{2}=451,5 \cdot c^{0,5}\left(f^{\prime}{ }_{c}\right)^{-0,9}$

$q_{3}=0,29(w / c)^{4} q_{2}$ 
$q_{4}=0,14(a / c)^{-0,7}$

$q_{5}=7,57 \cdot 10^{5}{f^{\prime}}_{c}^{-1} \varepsilon_{\text {sho }}^{-0,6}$

W/c - relação água cimento

$c$ - consumo de água $\left(\mathrm{lb} / \mathrm{ft}^{3}\right)$

$t$ - idade do concreto (dias)

$t^{\prime}$ - idade do carregamento (dias)

$t_{0}$ - idade do início da secagem em dias (somente $t_{0} \leq t$ ' são considerados)

$\mathrm{h}$ - umidade relativa do ambiente em porcentagem $(0 \leq \mathrm{h} \leq 1)$

$v / s$ - relação entre o volume por área de superfície (polegadas)

a/c - relação agregado cimento

$f_{c}^{\prime}$ - resistência média à compressão (psi)

E - módulo de elasticidade do concreto aos 28 dias (psi), dado pela eq.(2-76).

$$
E=57000 f_{c}^{\prime 1 / 2}
$$

$E(t)$ - módulo de elasticidade do concreto aos $t$ dias (psi), dado pela eq.(2-77).

$$
E(t)=E\left[\frac{t}{(4+0,85 t)}\right]^{1 / 2}
$$

A resistência característica à compressão (psi) é dada pela eq.(2-78):

$f_{c}^{\prime}=f_{c k}+1200$

A deformação por retração ao longo do tempo é dada pelas eq.(2-79), eq.(2-80) e eq.(2-81):

$\varepsilon_{c s}\left(t, t_{0}\right)=-\varepsilon_{s \infty}\left(\infty, t_{s}\right) k_{h} S(t)$

$\varepsilon_{s \infty}\left(\infty, t_{s}\right)=\varepsilon_{s \infty} \frac{E(7+600)}{E\left(t_{0}+\tau_{s h}\right)}$

$\varepsilon_{\text {so }}=\alpha_{1} \alpha_{2}\left[26 w^{2,1} f^{\prime}{ }_{c}{ }^{-0,28}+270\right]\left(10^{-6}\right)$

$w$ - consumo de água $\left(\mathrm{lb} \mathrm{ft}^{-3}\right)$

$\alpha_{1}$ - coeficiente que depende do tipo de cimento dado por:

1 para tipo de cimento I

0,85 para tipo de cimento II 
1,1 para tipo de cimento III

$\alpha_{2}$ - coeficiente que depende do tipo de cura dado por:

0,75 para cura a vapor

1 para cura em água ou $100 \%$ de umidade relativa

1,2 para cura selada

\subsubsection{Gardner e Lockman (2001)}

O presente modelo de previsão está restrito a tensões da ordem de $40 \%$ da resistência à compressão média do concreto, assumindo que a retração, a fluência básica e a de secagem podem ser somadas.

A seguir são apresentadas as expressões de previsão do coeficiente de fluência $\phi_{28}$ dada pela eq.(2-82), entre o tempo $t$ e $t_{0}$, em relação à deformação elástica aos 28 dias do modelo GL de previsão de fluência para análise e projetos de estruturas de concreto.

$\phi_{28}=\phi\left(t_{c}\right)\left[2\left(\frac{\left(t-t_{0}\right)^{0,3}}{\left(t-t_{0}\right)^{0,3}+14}\right)+\left(\frac{7}{t_{0}}\right)^{0,5}\left(\frac{t-t_{0}}{t-t_{0}+7}\right)^{0,5}+2,5\left(1-1,086 h^{2}\right)\left(\frac{t-t_{0}}{t-t_{0}+0,15(\mathrm{~V} / \mathrm{S})^{2}}\right)^{0,5}\right]$

$\Phi\left(t_{c}\right)$ - coeficiente de correção que considera a secagem antes do carregamento dada pela eq.(2-83):

$\phi\left(t_{c}\right)=\left[1-\left(\frac{t-t_{c}}{t-t_{c}+0,12(\mathrm{~V} / \mathrm{S})^{2}}\right)^{0,5}\right]^{0,5}$

$\phi\left(t_{c}\right)=1$, para $t_{0}=t_{c}$

$t$ - idade do concreto no instante considerado (dias)

$t_{0}$ - idade do concreto quando carregado (dias)

$t_{c}$ - idade do concreto no início do processo de secagem (dias)

$h$ - umidade relativa do ambiente (decimal)

$V / S$ - relação volume área superficial $(\mathrm{mm})$

A deformação por retração é dada pelas eq.(2-84), eq.(2-85) e eq.(2-86): 
$\varepsilon_{\text {sh }}=\varepsilon_{\text {shu }} \beta(h) \beta(t)$

$\beta(h)=\left(1-1,18 h^{4}\right)$

$\beta(t)=\left(\frac{t-t_{c}}{t-t_{c}+0,12(V / S)}\right)^{0,5}$

$\beta(h)$ - coeficiente de correção do efeito da umidade relativa na retração

$\varepsilon_{\text {shu }}\left(\infty, t_{s}\right)$ - deformação por retração última dada pela eq.(2-87):

$\varepsilon_{\text {shu }}=900 K\left(\frac{30}{f_{\text {cm28 }}}\right)^{0,5} 10^{-6}$

$h$ - umidade relativa do ambiente (decimal)

$K$ - coeficiente dependente do tipo de cimento dado por:

1,0 para tipo de cimento I

0,75 para tipo de cimento II

1,15 para tipo de cimento III

$V / S$ - relação volume superfície $(\mathrm{mm})$

$f_{c m 28}$ - resistência média à compressão do concreto a 28 dias $(\mathrm{MPa})$

A relação do desenvolvimento da resistência à compressão média pela resistência à compressão na idade $t$ é dada pela eq.(2-88):

$f_{c m t}=\left\{\exp \left[\frac{s}{2}\left(1-\sqrt{\frac{28}{t}}\right)\right]\right\}^{2} f_{c m 28}$

$f_{c m t}$ - resistência à compressão média na idade $t(\mathrm{MPa})$

$s$ - coeficiente dependente do tipo de cimento

0,335 para tipo de cimento I

0,4 para tipo de cimento II

0,13 para tipo de cimento III

A resistência característica à compressão $(\mathrm{MPa})$ pode ser relacionada com a resistência média à compressão pela eq.(2-89):

$f_{c m 28}=1,1 f_{c k 28}+5$

O módulo de elasticidade (MPa) na idade $t$ é dado pela eq.(2-90):

$E_{c m t}=3500+4300\left(f_{c m t}\right)^{1 / 2}$ 


\subsubsection{NBR6118 (2004)}

O modelo descrito nesta norma divide a deformação por fluência do concreto $\left(\varepsilon_{c c}\right)$ dada pela eq.(2-91), em duas partes, sendo uma delas chamada de fluência rápida $\left(\varepsilon_{c c a}\right)$ e a outra de fluência lenta. A primeira parte é dita irreversível e seu efeito é significativo durante as primeiras vinte e quatro horas após a aplicação da carga de origem. A segunda parte é composta por duas outras parcelas, uma lenta e irreversível $\left(\varepsilon_{c c f}\right)$ e a outra lenta e reversível $\left(\varepsilon_{c c d}\right)$. Assim, a deformação total e o coeficiente de fluência são definidos pelas eq.(2-92) e eq.(2-93):

$\varepsilon_{\mathrm{cc}}=\varepsilon_{\mathrm{cca}}+\varepsilon_{\mathrm{ccf}}+\varepsilon_{\mathrm{ccd}}$

$\varepsilon_{\mathrm{C}^{\prime} \text { total }}=\varepsilon_{\mathrm{c}}+\varepsilon_{\mathrm{cC}}=\varepsilon_{\mathrm{c}}(1+\varphi)$

$\varphi=\varphi_{\mathrm{a}}+\varphi_{\mathrm{f}}+\varphi_{\mathrm{d}}$

$\varphi_{a}$ - coeficiente de fluência rápida

$\varphi_{f}$ - coeficiente de deformação lenta irreversível

$\varphi_{d}$ - coeficiente de deformação lenta reversível

Este método apresenta algumas hipóteses de simplificação para aplicação no cálculo dos efeitos da fluência para concreto submetido às tensões de serviço. Estas hipóteses são descritas abaixo:

- A deformação por fluência $\varepsilon_{c c}$ varia linearmente com a tensão aplicada;

- Para acréscimos de tensão aplicados em instantes distintos, os respectivos efeitos de fluência se superpõem;

- A fluência rápida produz deformações constantes ao longo do tempo;

- Os valores do coeficiente $\varphi_{a}$ são função da relação entre a resistência do concreto no momento da aplicação da carga e a sua resistência final;

- O coeficiente de deformação lenta reversível $\varphi_{d}$ depende apenas da duração do carregamento; o seu valor final e o seu desenvolvimento ao longo do tempo são independentes da idade do concreto no momento da aplicação da carga;

- O coeficiente de deformação lenta irreversível $\varphi_{f}$ depende da: umidade relativa do ambiente $(U)$; consistência do concreto no lançamento (abatimento); espessura fictícia da peça $\left(h_{\text {fic }}\right)$; idade fictícia do concreto no 
instante $t_{o}$ da aplicação da carga e da idade fictícia do concreto no instante considerado $(t)$;

- Para o mesmo concreto, as curvas de deformação lenta irreversível em função do tempo, correspondentes a diferentes idades do concreto no momento do carregamento, são obtidas, umas em relação às outras, por deslocamento paralelo ao eixo das deformações conforme gráfico 2.10.

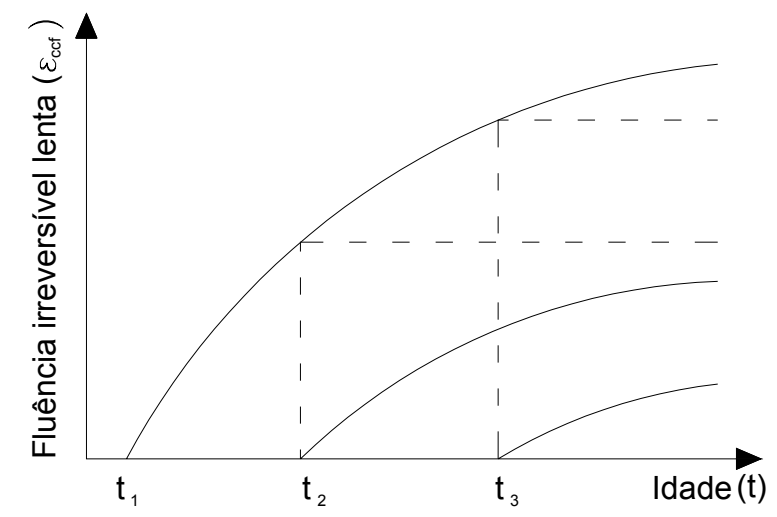

Gráfico 2.10 - Curvas de $\varepsilon_{c c f}(t)$ (Fonte: NBR6118, 2004).

O valor da deformação específica do concreto devido à fluência é dado pela eq.(2-94):

$\varepsilon_{c c}\left(t, t_{o}\right)=\frac{\sigma_{\mathrm{c}}}{\mathrm{E}_{\mathrm{cs} 28}} \cdot \varphi\left(\mathrm{t}, \mathrm{t}_{\mathrm{o}}\right)$

$E_{c s 28}$ - módulo de elasticidade secante aos 28 dias (MPa), calculado conforme eq.(2-95):

$E_{c s 28}=0,85 \cdot 5600 \sqrt{f_{c k}}$

O coeficiente de fluência $\varphi\left(t, t_{0}\right)$, válido também para a tração, é dado pela eq.(2-96):

$\varphi\left(t, t_{o}\right)=\varphi_{a}+\varphi_{f \infty}\left[\beta_{f}(t)-\beta_{f}\left(t_{o}\right)\right]+\varphi_{d \infty} \beta_{d}$

$t$ - idade fictícia do concreto no instante considerado (dias)

$t_{o}$ - idade fictícia do concreto ao ser feito o carregamento (dias)

$\varphi_{a}$ - coeficiente de fluência rápida, determinado pela eq.(2-97):

$\varphi_{a}=0,8\left[1-\frac{f_{c}\left(t_{0}\right)}{f_{c}\left(t_{\infty}\right)}\right]$

$\frac{f_{c}\left(t_{o}\right)}{f_{c}\left(t_{o o}\right)}=$ função de crescimento da resistência do concreto com a idade, dadas pelas eq.(2-98) e eq.(2-99): 
$\beta_{1}=\frac{f_{c}\left(t_{o}\right)}{f_{c}\left(t_{o o}\right)}$

$\beta_{1}=\exp \left\{\alpha\left[1-\left(\frac{28}{t}\right)^{1 / 2}\right]\right\}$

$\alpha$-coeficiente que depende do tipo de cimento, dado por:

0,38 para concreto de cimento CPIII e IV

0,25 para concreto de cimento CPI e II

0,20 para concreto de comento CPV-ARI

$t$ - idade fictícia do concreto (dias)

$\varphi_{f \infty}$ - valor final do coeficiente de deformação lenta irreversível dada pela eq.(2-100).

$\varphi_{f \circ}=\varphi_{1 c} \cdot \varphi_{2 c}$

$\varphi_{1 c}$ - coeficiente dependente da umidade relativa do ambiente e da consistência do concreto dado na tabela 2.7

$\varphi_{2 c}$ - coeficiente dependente da espessura fictícia $h_{\text {fic }}$ da peça dada pela eq.(2-101):

$\varphi_{2 c}=\frac{42+\mathrm{h}_{\text {fic }}}{20+\mathrm{h}_{\text {fic }}}$

$\beta_{f}(t)$ ou $\beta_{f}\left(t_{0}\right)$ - coeficiente relativo à deformação lenta irreversivel, função da idade do concreto (gráfico 2.11), ou dado pela eq.(2-102):

$$
\begin{aligned}
& \beta_{f}(t)=\frac{t^{2}+A t+B}{t^{2}+C t+D} \\
& A=42 h^{3}-350 h^{2}+588 h+113 \\
& B=768 h^{3}-3060 h^{2}+3234 h-23 \\
& C=-200 h^{3}+13 h^{2}+1090 h+183 \\
& D=7579 h^{3}-31916 h^{2}+35343 h+1931
\end{aligned}
$$

$\varphi_{d \infty}$ - valor final do coeficiente de deformação lenta reversível que é considerado igual a 0,4

$\beta_{d}$ - coeficiente relativo à deformação lenta reversível função do tempo $\left(t, t_{0}\right)$ decorrido após o carregamento, definido pela eq.(2-103): 


$$
\beta_{d}=\frac{t-\mathrm{t}_{0}+20}{t-\mathrm{t}_{0}+70}
$$

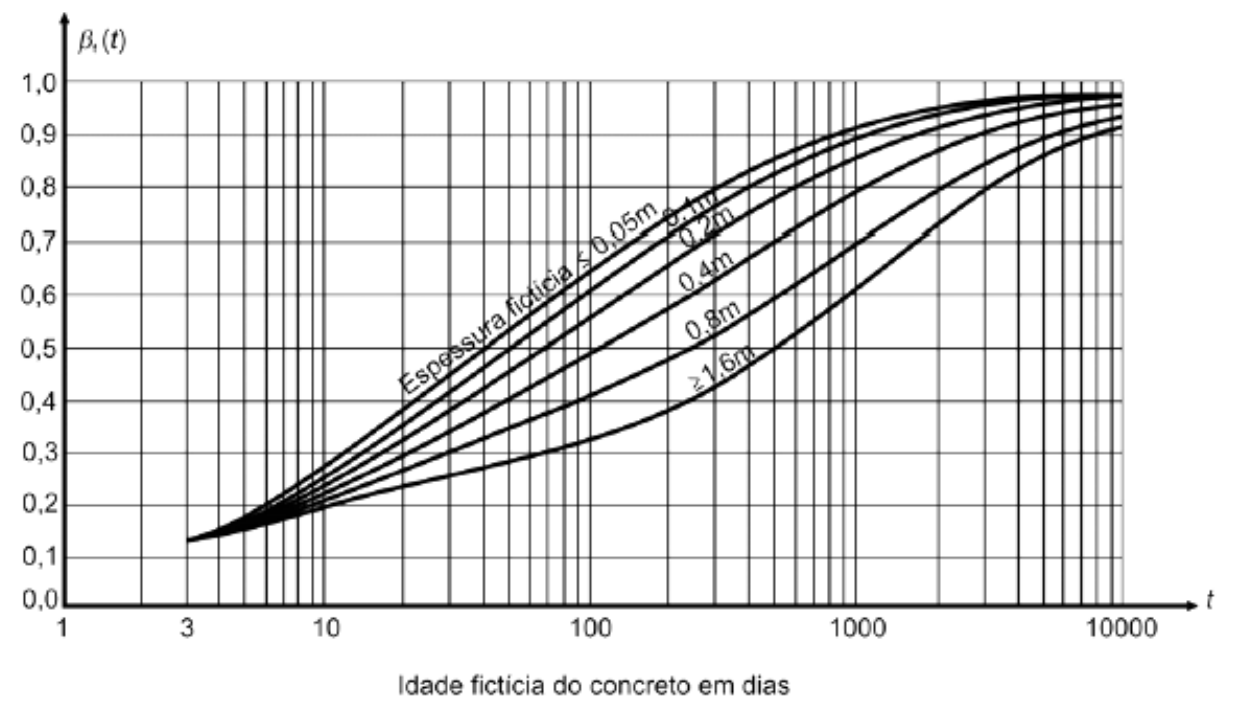

Gráfico 2.11 - Ábaco da variação $\beta_{f}(t)$ em relação à idade fictícia do concreto em dias (Fonte: NBR6118, 2004).

Segundo a NBR6118 (2004), o valor da retração do concreto depende da:

a) umidade relativa do ambiente;

b) consistência do concreto no lançamento;

c) espessura fictícia da peça.

Dessa forma, a deformação devido à retração entre os instantes $t_{0}$ e $t$ pode ser expressa pela eq.(2-104):

$\varepsilon_{c s}\left(t, t_{0}\right)=\varepsilon_{s \infty}\left(\infty, t_{s}\right) \cdot\left[\beta_{s}(t)-\beta_{s}\left(t_{0}\right)\right]$

$\varepsilon_{s \infty}\left(\infty, t_{s}\right)$ - deformação por retração última dada pela eq.(2-105):

$\varepsilon_{s \infty}\left(\infty, t_{s}\right)=\varepsilon_{1 s} \cdot \varepsilon_{2 s}$

$\varepsilon_{1 s}$ - coeficiente dependente da umidade relativa do ambiente e da consistência do concreto apresentado na tabela 2.7

$\varepsilon_{2 s}$ - coeficientes que depende da espessura fictícia da peça, dada pela eq.(2-106):

$\varepsilon_{2 s}=\frac{33+2 \cdot h_{\text {fic }}}{20,8+3 \cdot h_{\text {fic }}}$ 
Tabela 2.7 - Valores usuais para a determinação da fluência e da retração (Fonte: NBR6118, 2004).

\begin{tabular}{|c|c|c|c|c|c|c|c|c|}
\hline \multirow{4}{*}{ Ambiente } & \multirow{4}{*}{$\begin{array}{c}\text { Umidade } \\
\qquad \begin{array}{c}U \\
\%\end{array}\end{array}$} & & $\begin{array}{l}\text { luência } \\
\varphi_{1 c}{ }^{1)^{3)}}\end{array}$ & \multicolumn{4}{|c|}{$\begin{array}{l}\text { Retração } \\
10^{4} \varepsilon_{1 s}^{2) 3)}\end{array}$} & \multirow{4}{*}{$\gamma^{4)}$} \\
\hline & & \multirow{2}{*}{\multicolumn{6}{|c|}{$\begin{array}{l}\text { Abatimento de acordo com a ABNT NBR NM67 } \\
\qquad \mathrm{cm}\end{array}$}} & \\
\hline & & & & & & & & \\
\hline & & $0-4$ & $5-9$ & $10-15$ & $0-4$ & $5-9$ & $10-15$ & \\
\hline Na água & - & 0,6 & 0,8 & 1,0 & $+1,0$ & $+1,0$ & $+1,0$ & 30,0 \\
\hline $\begin{array}{l}\text { imediatamente } \\
\text { acima da água }\end{array}$ & 90 & 1,0 & 1,3 & 1,6 & $-1,0$ & $-1,3$ & $-1,6$ & 5,0 \\
\hline Ao ar livre, em geral & 70 & 1,5 & 2,0 & 2,5 & $-2,5$ & $-3,2$ & $-4,0$ & 1,5 \\
\hline Em ambiente seco & 40 & 2,3 & 3,0 & 3,8 & $-4,0$ & $-5,2$ & $-6,5$ & 1,0 \\
\hline \multicolumn{9}{|c|}{$\begin{array}{l}\text { 1) } \varphi_{t 0}=4,45-0,035 U \text { para abatimento no intervalo de } 5 \mathrm{~cm} \text { a } 9 \mathrm{~cm} \text { e } U \leq 90 \% . \\
10^{4} \varepsilon_{1 s}=-6,16-(U / 484)+\left(U^{2} / 1590\right) \text { para abatimentos de } 3 \mathrm{~cm} \text { a } 9 \mathrm{~cm} \text { e } U \leq 90 \% . \\
\text { Os valores de } \varphi_{1 c} \text { e } \varepsilon_{1 \mathrm{~s}} \text { para } U \leq 90 \% \text { e abatimento entre } 0 \mathrm{~cm} \text { e } 4 \mathrm{~cm} \text { são } 25 \% \text { menores e para abatimentos } \\
\text { entre } 10 \mathrm{~cm} \text { e } 15 \mathrm{~cm} \text { são } 25 \% \text { maiores. } \\
\gamma=1+\exp (-7,8+0,1 U) \text { para } U \leq 90 \%\end{array}$} \\
\hline \multicolumn{9}{|c|}{$\begin{array}{l}1 \text { - Para efeito de cálculo, as mesmas expressões e os mesmos valores numéricos podem ser empregados no caso } \\
\text { de tração. }\end{array}$} \\
\hline \multicolumn{9}{|c|}{$\begin{array}{l}2 \text { - Para o cálculo dos valores de fluência e retração, a consistência do concreto é aquela correspondente à obtida } \\
\text { com o mesmo traço sem a adição de superplastificantes e superfluidificantes. }\end{array}$} \\
\hline
\end{tabular}

$h_{\text {fic }}$ - espessura fictícia dada pela eq.(2-107):

$h_{\text {fic }}=\gamma \times \frac{2 \times A_{c}}{u}$

$A_{c}$ - área da seção transversal da peça

$u$ - perímetro externo da seção transversal em contato com o ar

É importante notar que a espessura fictícia é utilizada nos modelos de previsão de fluência e retração com unidades distintas para determinação de cada parâmetro $\left(\varphi_{2 c}-\right.$ centímetros, $\beta_{f}(t)-$ metros, $\varepsilon_{s 2}$ - centímetros).

$\gamma$ - coeficiente dependente da umidade relativa do ambiente. Coeficiente dado na tabela 2.7 .

$\beta_{s}(t)$ ou $\beta_{s}\left(t_{0}\right)$ - coeficiente relativo à retração, no instante $t$ ou $t_{0}$ dado pelo gráfico

2.12 ou pela eq. $(2-108)$ :

$\beta_{s}(t)=\frac{\left(\frac{\mathrm{t}}{100}\right)^{3}+A\left(\frac{\mathrm{t}}{100}\right)^{2}+B\left(\frac{\mathrm{t}}{100}\right)}{\left(\frac{\mathrm{t}}{100}\right)^{3}+C\left(\frac{\mathrm{t}}{100}\right)^{2}+D\left(\frac{\mathrm{t}}{100}\right)+E}$ 


$$
A=40
$$

$B=116 h^{3}-282 h^{2}+220 h-4,8$

$C=2,5 \mathrm{~h}^{3}-8,8 \mathrm{~h}^{2}+40,7$

$D=-75 h^{3}+585 h^{2}+496 h-6,8$

$E=-169 h^{4}+88 h^{3}+584 h^{2}-39 h+0,8$

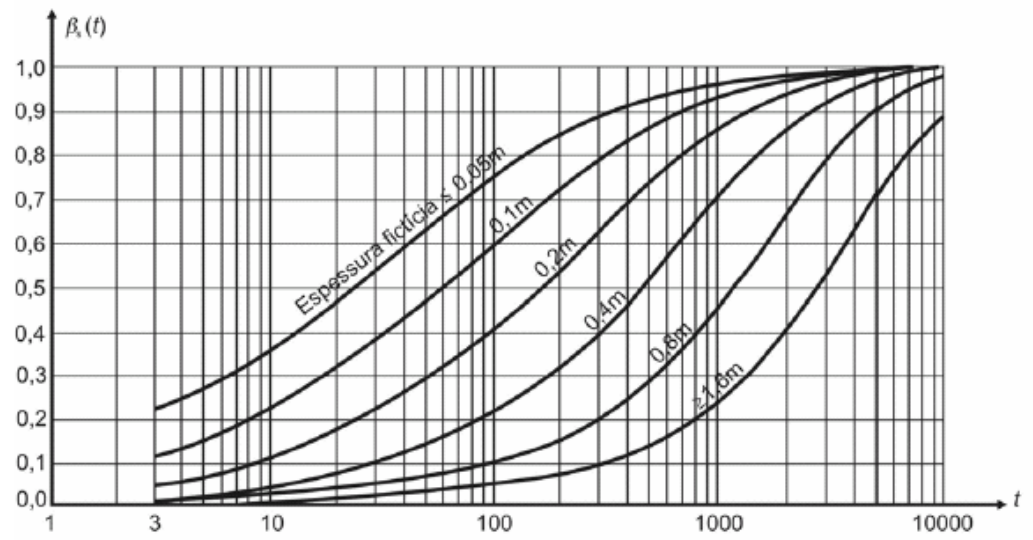

Gráfico 2.12 - Variação de $\beta_{s}(t)$ em relação ao tempo em dias (Fonte: NBR6118, 2004).

$t$ - idade fictícia do concreto (dias) é dada pela eq.(2-109).

$t=\alpha \sum_{i} \frac{T_{i}+10}{30} \times \Delta t_{e f, i}$

$\alpha$ - coeficiente dependente da velocidade de endurecimento do cimento dado pela tabela 2.8

$T_{i}$ - temperatura média diária do ambiente $\left({ }^{\circ} \mathrm{C}\right)$

$\Delta t_{e f, i}$ - período em que a temperatura média diária do ambiente se manteve constante (dias)

Tabela 2.8 - Valores da fluência e da retração em função da velocidade de endurecimento do cimento (Fonte: NBR6118, 2004).

\begin{tabular}{lcc}
\hline \multicolumn{1}{c}{ Cimento Portland (CP) } & \multicolumn{2}{c}{$\alpha$} \\
\cline { 2 - 3 } & Fluência & Retração \\
\hline De endurecimento lento (CP III E CP IV, todas as classes de resistência) & 1 & \multirow{2}{*}{1} \\
\hline De endurecimento normal (CP I e CP II, todas as classes de resistência) & \\
\hline De endurecimento rápido (CP V-ARI) & 3 \\
\hline Onde: & \\
CP I e CP I-S - Cimento Portland comum; & \\
CP II-E, CP II-F e CP II-Z - Cimento Portland composto; \\
CP III - Cimento Portland de alto-forno; \\
CP IV - Cimento Portland pozolânico; \\
CP V-ARI - Cimento Portland de alta resistência inicial; \\
RS - Cimento Portland resistente a sulfatos (propriedade específica de alguns dos tipos de cimento citados)
\end{tabular}


A NBR6118 (2004) também prescreve valores médios finais dos coeficientes de fluência e retração através de uma tabela (tabela 2.9).

Tabela 2.9 - Valores característicos superiores para a deformação específica de retração $\varepsilon_{\mathrm{cs}}\left(\infty, \mathrm{t}_{0}\right)$ e o coeficiente de fluência $\varphi\left(\infty, \mathrm{t}_{0}\right)$ (Fonte: NBR6118, 2004).

\begin{tabular}{|c|c|c|c|c|c|c|c|c|c|c|}
\hline \multirow{2}{*}{\multicolumn{3}{|c|}{$\begin{array}{c}\text { Umidade Ambiente (\%) } \\
\text { Espessura Fictícia } \\
\left(2 \mathrm{~A}_{\mathrm{c}} / \mathrm{u}\right)\end{array}$}} & \multicolumn{2}{|c|}{40} & \multicolumn{2}{|c|}{55} & \multicolumn{2}{|c|}{75} & \multicolumn{2}{|c|}{90} \\
\hline & & & 20 & 60 & 20 & 60 & 20 & 60 & 20 & 60 \\
\hline \multirow{3}{*}{$\varphi\left(\mathrm{t}_{\infty}, \mathrm{t}_{0}\right)$} & \multirow{6}{*}{$\begin{array}{c}\mathrm{t}_{0} \\
\text { dias }\end{array}$} & 5 & 4,4 & 3,9 & 3,8 & 3,3 & 3,0 & 2,6 & 1,3 & 2,1 \\
\hline & & 30 & 3,0 & 2,9 & 2,6 & 2,5 & 2,0 & 2,0 & 1,6 & 1,6 \\
\hline & & 60 & 3,0 & 2,6 & 2,2 & 2,2 & 1,7 & 1,8 & 1,4 & 1,4 \\
\hline \multirow{2}{*}{$\begin{array}{c}\varepsilon_{\mathrm{cs}} \\
\left(\mathrm{t}_{\infty}, \mathrm{t}_{0}\right)\end{array}$} & & 5 & $-0,44$ & $-0,39$ & $-0,37$ & $-0,33$ & $-0,23$ & $-0,21$ & $-0,10$ & $-0,09$ \\
\hline & & 30 & $-0,37$ & $-0,38$ & $-0,31$ & $-0,31$ & $-0,20$ & $-0,20$ & $-0,09$ & $-0,09$ \\
\hline$\%$ & & 60 & $-0,32$ & $-0,36$ & $-0,27$ & $-0,30$ & $-0,17$ & $-0,19$ & $-0,08$ & $-0,09$ \\
\hline
\end{tabular}

2.3.6 Estudos realizados de comparação entre resultados experimentais e modelos de previsão de fluência e retração

Para comparação de diferentes modelos de previsão de fluência e retração, é necessário estabelecer condições equivalentes para os parâmetros de entrada (SASSONE; CHIORINO, 2005).

Uma das principais dificuldades encontradas para comparar modelos de previsão é a correlação entre os tipos de cimentos, pois dificilmente há equivalência entre cimentos correspondentes de diferentes países. Por exemplo, o $\mathrm{ACl}$ não possui uma equação de desenvolvimento da resistência com o tempo para o tipo II do ASTM (GARDNER, 2004). Dessa forma, nesta pesquisa, é estabelecida uma correlação entre os tipos de cimentos de outros países com os cimentos nacionais, como pode ser visto na tabela 2.10:

Tabela 2.10 - Correlação entre os tipos de cimento.

\begin{tabular}{ccccc}
\hline NBR & ACI & EC2 & B3 & GL \\
\hline CPI & ASTM I & $\mathrm{N}$ & ASTM I & ASTM I \\
CPII & ASTM I & $\mathrm{N}$ & ASTM I & ASTM I \\
CPIII & ASTM IS & $\mathrm{S}$ & ASTM IS & ASTM II* \\
CPIV & ASTM IP & $\mathrm{S}$ & ASTM IP & ASTM II* \\
CPV & ASTM III & $\mathrm{R}$ & ASTM III & ASTM III \\
\hline
\end{tabular}

${ }^{\star}$ Curva ajustada a partir do tipo ASTM I (GL). 
Além disso, outra dificuldade é a especificação da resistência à compressão em diferentes modelos. Todas as normas, com exceção do $\mathrm{ACl}$, possuem a formulação para resistência característica à compressão $\left(\mathrm{f}_{\mathrm{ck}}\right)$. Entretanto, somente o modelo da NBR considera a resistência característica do concreto aos 28 dias na previsão da fluência e retração, enquanto que os outros modelos consideram a resistência média à compressão aos 28 dias $\left(f_{\mathrm{cm} 28}\right)$. Portanto, nesta pesquisa, é adotada a resistência referente a cada modelo.

Neste item, são apresentados os resultados experimentais mais relevantes de alguns autores, assim com a comparação entre estes resultados e os modelos de fluência e retração. Além disso, são citados e discutidos os métodos estatísticos existentes para a comparação destes resultados, assim como está descrito o método utilizado nesta pesquisa.

\subsubsection{ANÁLISE ESTATÍSTICA}

Diversos métodos estatísticos são utilizados para avaliar a precisão dos modelos em prever os resultados experimentais. Um grupo único de dados pode ser comparado utilizando valores estatísticos simples como a média, moda, mediana, desvio padrão, máximo e mínimo.

No estudo comparativo entre modelos e resultados experimentais de fluência e retração, um dos problemas que ocorre com métodos estatísticos é que, à medida que as deformações por fluência e retração evoluem com tempo, a dispersão dos dados aumenta. Assim, quando métodos como a regressão linear são utilizados, o peso dos resultados experimentais relativos a idades mais avançadas é maior do que para idades menores. O contrário ocorre quando são comparados modelos e resultados experimentais utilizando o desvio. Neste caso, o peso maior é dado para idades menores (VIDELA, 2006).

Os métodos estatísticos mais utilizados para comparar resultados experimentais de fluência e retração com modelos de previsão são:

- Comparação individual entre a curva de previsão do modelo com cada grupo de resultados experimentais; 
- Comparação dos resultados experimentais com os resultados provenientes de modelos de previsão utilizando regressão linear. A vantagem deste método é que rápida e claramente é possível verificar a precisão do modelo de previsão. Entretanto, este método apresenta o problema supracitado dos pesos;

- Avaliação dos residuais. Este método consiste em calcular a diferença entre os resultados experimentais e os resultados analíticos. Os valores positivos e negativos dos residuais indicam que o modelo superestima e subestima os resultados experimentais, respectivamente;

- Cálculo do coeficiente de variação. Existem diversos coeficientes de variação, tais como: coeficiente de variação B3 $\left(\omega_{B 3}\right)$; coeficiente de variação $\mathrm{CEB}\left(\mathrm{V}_{\mathrm{CEB}}\right)$; dentre outros, como o coeficiente de variação do Gardner (2004) $\left(\omega_{G}\right)$. Estes coeficientes são os indicadores estatísticos mais aceitos, segundo Videla (2006).

De acordo com o ACl209R (1992) Committee apud Videla (2006) não há um indicador estatístico disponível adequado para comparação. Entretanto, considerando que os coeficientes de variação são os indicadores mais aceitos, para fins comparativos, nesta pesquisa é utilizado o método estatístico do coeficiente de variação B3 $\left(\omega_{B 3}\right)$. Este método estatístico foi selecionado, pois envolve um procedimento de análise complexo quando comparado com outros (ALMANASSEER; LAM, 2005), sugerindo que seja mais preciso. Além disso, de acordo com Bažant; Li e Yu (2008) afirmaram existir problemas em diversos indicadores estatísticos, tais como $V_{C E B} e \circ \omega_{G}$, levando a comparações estatísticas inválidas e incorretas.

Portanto, para confrontar modelos de fluência e retração com resultados experimentais de cada traço, foi utilizado o indicador estatístico do $B 3\left(\omega_{B}\right)$.

O método do coeficiente de variação B3 foi desenvolvido por Bažant e Baweja (2000). Primeiramente, o coeficiente de variação $\omega_{B 3}$ é determinado para cada grupo de dados, conforme eq.(2-110), eq.(2-111) a eq.(2-112). O coeficiente de variação da população para todos os grupos de dados $\omega_{B 3, \text { all }}$ é dado pela eq.(2-113). Para cada grupo, os dados em cada década são considerados como 
um único grupo e cada dado do grupo recebe um peso. O peso é dado para cada ponto baseado na década em que se localiza e o número de ponto da década.

$$
\begin{aligned}
& \omega_{B 3, j}=\frac{1}{\bar{J}_{j}} \sqrt{\frac{1}{n-1} \sum_{i=1}^{n}\left(\omega_{i j} \Delta_{i j}\right)^{2}} \\
& \bar{J}_{j}=\frac{1}{n} \sum_{i=1}^{n}\left(\omega_{i j} J_{i j}\right) \\
& \omega_{i j}=\frac{n}{n_{d} n_{1}} \\
& \omega_{B 3, a l l}=\sqrt{\frac{1}{N} \sum_{j=1}^{N}\left(\omega_{j}\right)^{2}}
\end{aligned}
$$

$n$ - número de dados medidos em um grupo, j

$n_{1}$ - número de dados medidos em uma década

$n_{d}$ - número de décadas em escala logarítmica para dados medidos do grupo, $\mathrm{j}$

$N$ - número de grupo de dados

$J_{j}$ - dados medidos em um grupo de dados, $\mathrm{j}$

$\Delta_{j}-$ desvio dos dados medidos com os modelos

$\omega_{i j}$ - peso dado para os dados medidos

$\omega_{B 3, j}$ - coeficiente de variação para um grupo de dados, $\mathrm{j}$

$\omega_{B 3, a l l}$ - coeficiente de variação da população para todos os grupos de dados

De acordo com Gardner e Lockman (2001) e Videla; Covarrubias e Masana (2004), um modelo é considerado capaz de prever as deformações de fluência e retração quando o coeficiente de variação é de aproximadamente 20\%. Bažant (2001) afirma que o coeficiente de variação adequado para previsão das deformações de fluência (básica e por secagem) é de $23 \%$ e de retração (autógena e por secagem) é de $34 \%$. 


\subsubsection{PESQUISAS PRECEDENTES}

Alguns autores fizeram comparações entre modelos de retração e fluência com os resultados experimentais provenientes do RILEM data bank (BAŽANT; BAWEJA, 2000, GARDNER, 2004 e GOEL; KUMAR; PAUL, 2007). RILEM data bank é um banco de dados de retração e fluência que existe desde 1978, quando Bažant e Panula começaram a coletar dados do mundo todo (MULLER et al. 1999).

Entretanto, é importante ressaltar que Muller (1993) e outros autores encontraram problemas com o RILEM data bank, tais como:

- Inconsistência nos dados;

- Indefinição da umidade relativa para corpo de prova selados e imersos;

- Descrição do concreto, particularmente do tipo de cimento;

- Medições por tempo insuficiente, que reduz a eficiência dos dados para preverem efeitos de longo tempo;

- Muitos ensaios realizados em corpos de prova que provavelmente não representam grandes elementos estruturais;

- Dados insuficientes dos ensaios tal como retração antes do carregamento. Apesar destas limitações, o ACl 209 Committee considera indispensável que bancos de dados como os do RILEM sejam mantidos e atualizados uma vez que representam fontes de dados como base de comparação. Para tanto, é fundamental selecionar rigorosamente os grupos de dados a serem utilizados antes da avaliação destes na eficácia dos modelos (VIDELA, 2006).

Gardner (2004) considerou os dados do RILEM data bank com resistência média à compressão do concreto aos 28 dias entre 16 e $82 \mathrm{MPa}$; dados de mais de 500 dias; duração de cura de 1 dia ou mais; idade de carregamento maior que a duração da cura; relação volume superfície maior que $19 \mathrm{~mm}$; umidade relativa entre $20 \%$ e $100 \%$ para fluência e menor que $80 \%$ para retração. Foram analisados os modelos $\mathrm{ACl}, \mathrm{CEB}, \mathrm{B} 3$ e GL. A previsão empregando os modelos foi feita considerando dois tipos de dados de entrada: utilizando os dados de entrada disponíveis no RILEM data bank e utilizando como dado de entrada somente a resistência média à compressão, sendo que os demais parâmetros foram 
calculados e/ou estimados a partir desta. $O$ indicador estatístico utilizado foi o $\omega_{G}$ expresso nos gráficos 2.13 a 2.16 por coeficiente de variação (CV).

Gardner (2004) concluiu que no modelo de retração do ACl209 (1982) (gráfico 2.13a) há muita dispersão, superestimando os resultados experimentais nas primeiras idades e subestimando nas idades mais avançadas. O modelo de fluência do $\mathrm{ACl}$ (gráfico 2.13b) subestimou os resultados experimentais. O modelo B3 foi considerado bom para a previsão tanto da retração $\left(\omega_{G}=20 \%\right.$, para todos dados de entrada) quanto da fluência, como podem ser vistos nos gráficos 2.14a e 2.14b, respectivamente. O GL (gráficos $2.15 a$ e $2.15 b$ ) foi considerado tão bom quanto o modelo B3 para retração $\left(\omega_{G}=19 \%\right.$, para todos dados de entrada e $\omega_{G}=25 \%$ para dados de entrada calculados) e o melhor modelo para previsão da fluência $\left(\omega_{G}=22 \%\right.$, para todos dados de entrada e $\omega_{G}=26 \%$ para dados de entrada calculados). O CEB subestima a retração, mas foi razoável para fluência, como pode ser visto nos gráficos 2.16a e 2.16b.

Apesar de Gardner (2004) considerar os resultados do modelo do GL o mais representativo para fluência e retração, é necessário uma avaliação mais detalhada, pois o modelo não considera as proporções dos materiais, abatimento e método de cura, que constituem parâmetros influentes nas propriedades de fluência e retração. Al-Manasseer e Lam (2005) também compararam modelos de fluência e retração (ACI209R, 1992, CEB, B3 e GL) com os resultados do RILEM data bank considerando diversos métodos estatísticos (método dos residuais, $\omega_{\mathrm{b} 3}$, $\omega_{C E B}, F_{C E B}$ - erro médio ao quadrado e $M_{C E B}$ - média dos desvios), reforçando as conclusões obtidas por Gardner (2004). 


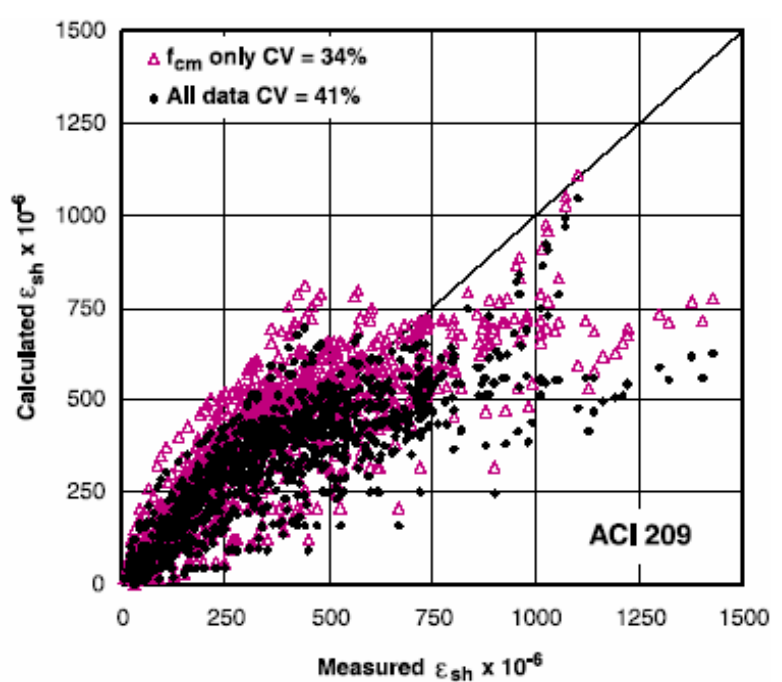

a) Deformação por retração.

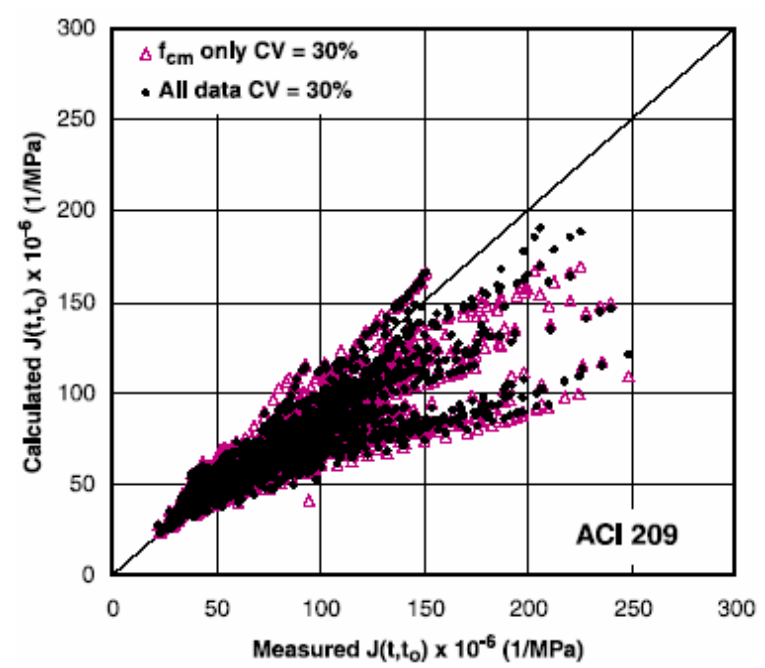

b) Fluência específica.

Gráfico 2.13 - Comparação do ACl com o RILEM data bank (Fonte: GARDNER, 2004).

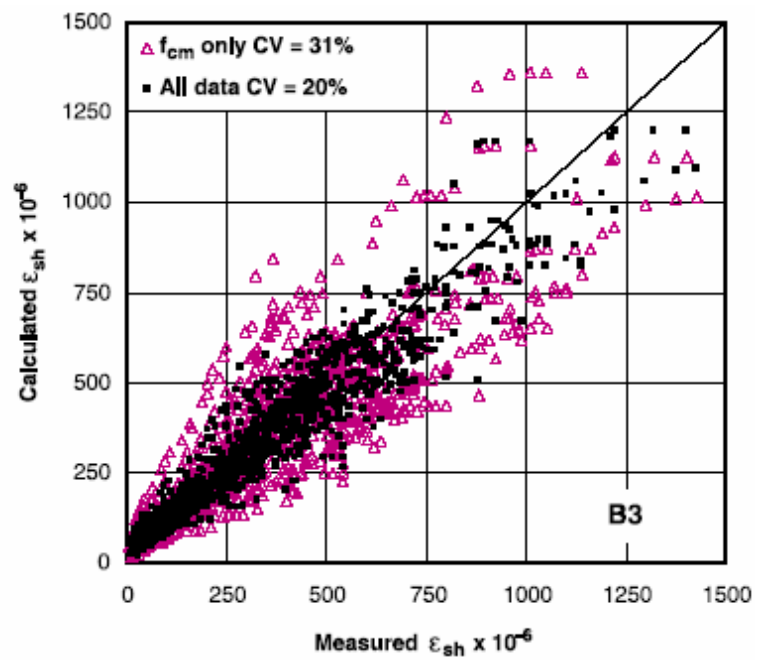

a) Deformação por retração.

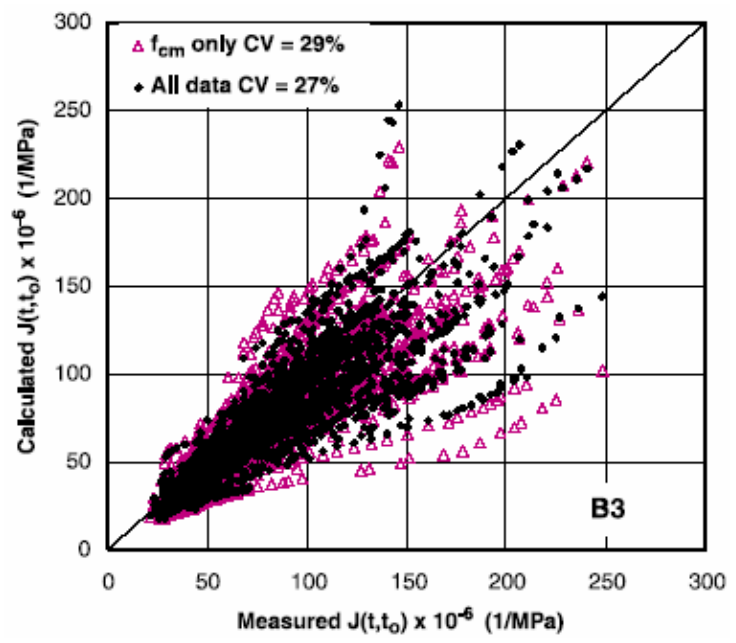

b) Fluência específica.

Gráfico 2.14 - Comparação do B3 com o RILEM data bank (Fonte: GARDNER, 2004).

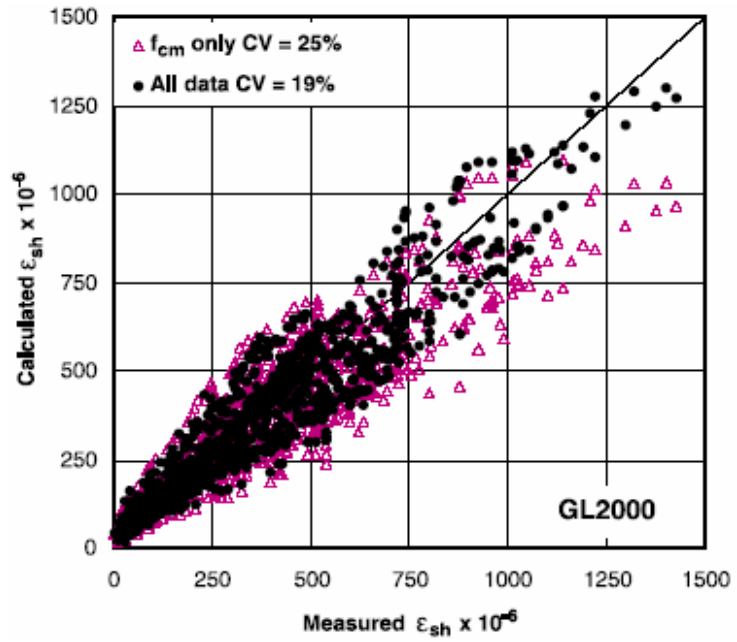

a) Deformação por retração.

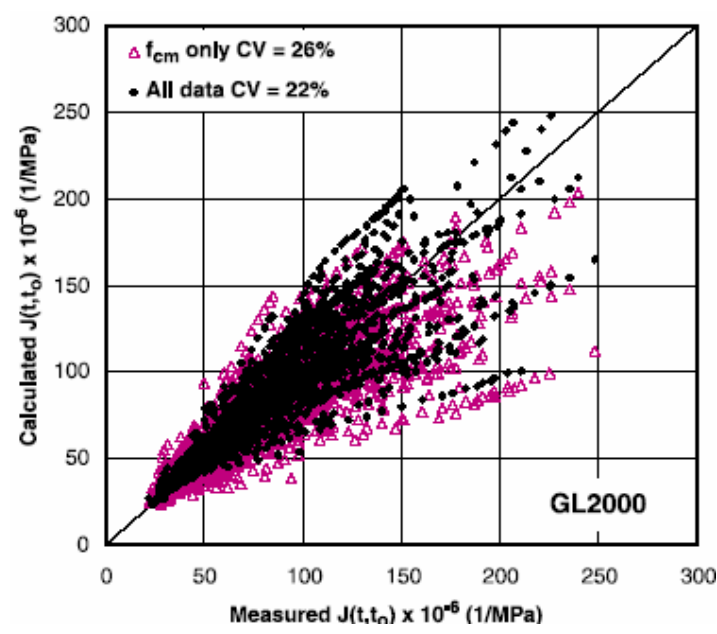

b) Fluência específica.

Gráfico 2.15 - Comparação do GL com o RILEM data bank (Fonte: GARDNER, 2004). 


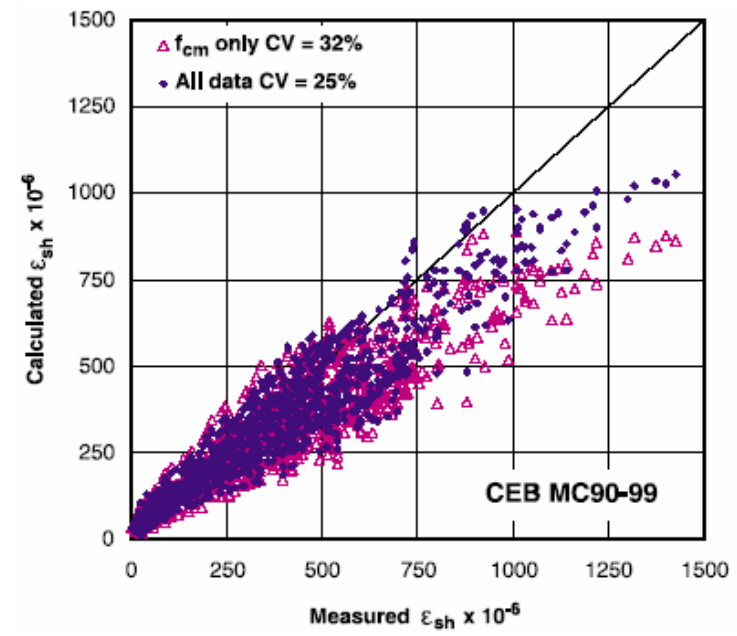

a) Deformação por retração.

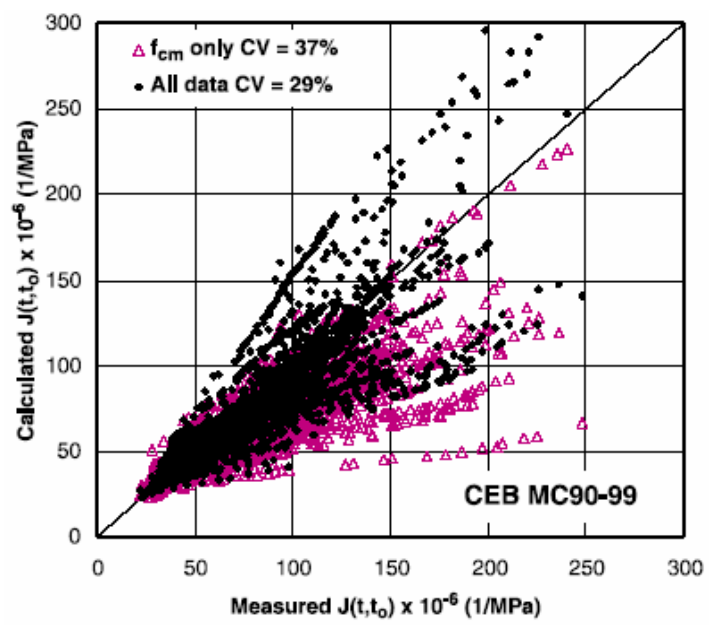

b) Fluência específica.

Gráfico 2.16 - Comparação do CEB com o RILEM data bank (Fonte: GARDNER, 2004).

Bažant e Baweja (2000) expressaram por meio do indicador estatístico $\omega_{\mathrm{B} 3}$, a comparação entre os modelos de previsão de fluência e retração com os dados do RILEM data bank, como pode ser visto nas tabelas 2.11 e 2.12. São considerados os modelos B3, CEB e ACI209R (1992). Na tabela 2.11 é interessante notar que para o modelo de fluência do B3, mesmo para idades de carregamento mais avançadas, ou seja, t’>1000dias, o coeficiente de variação permaneceu baixo. Além disso, no geral, os coeficientes de variação para o modelo B3 foram significantemente menores do que para os modelos do $\mathrm{CEB}$ e $\mathrm{ACl}$, tanto para retração quanto para fluência. Para idades mais avançadas, que são mais importantes, o modelo B3 se aproxima ainda mais das deformações experimentais apresentando baixo coeficiente de variação.

Bažant e Baweja (2000) afirmam que os desvios dos resultados experimentais com os modelos têm como principal causa erros dos modelos de previsão devido à consideração errônea dos parâmetros de composição dos materiais e resistência à compressão. Se estes parâmetros são ajustados, é possível obter modelos que são capazes de prever corretamente a fluência e a retração. 
Tabela 2.11 - Coeficiente de variação $\omega_{B 3}$ de diversos modelos de fluência para diferentes faixas de idade de carregamento e duração da fluência em dias (Fonte: BAŽANT; BAWEJA, 2000).

\begin{tabular}{|c|c|c|c|c|}
\hline \multicolumn{5}{|c|}{ Modelo B3 } \\
\hline$\omega_{\mathrm{B} 3}$ & $\mathrm{t}_{0} \leq 10$ & $10<t_{0} \leq 100$ & $100<t_{0} \leq 1000$ & $t_{0}>1000$ \\
\hline$t-t_{0} \leq 10$ & 17,8 & 24 & 19,8 & \\
\hline $10<t-t_{0} \leq 100$ & 13,7 & 23,1 & 25,3 & 29,3 \\
\hline $100<\mathrm{t}-\mathrm{t}_{0} \leq 1000$ & 13,9 & 20,5 & 22,6 & 33,6 \\
\hline$t-t_{0}>10$ & 12,7 & 14,6 & 17,8 & \\
\hline \multicolumn{5}{|c|}{ Modelo ACl } \\
\hline$\omega_{\mathrm{B} 3}$ & $t_{0} \leq 10$ & $10<t_{0} \leq 100$ & $100<t_{0} \leq 1000$ & $t_{0}>1000$ \\
\hline $\mathrm{t}-\mathrm{t}_{0} \leq 10$ & 60,3 & 30,7 & 33,3 & \\
\hline $10<t-t_{0} \leq 100$ & 45,7 & 36,7 & 49,9 & 97,1 \\
\hline $100<t-t_{0} \leq 1000$ & 34,6 & 39,9 & 51,7 & 93,9 \\
\hline$t-t_{0}>10$ & 36,8 & 39,9 & 40,9 & \\
\hline \multicolumn{5}{|c|}{ Modelo CEB } \\
\hline$\omega_{\mathrm{B} 3}$ & $t_{0} \leq 10$ & $10<t_{0} \leq 100$ & $100<t_{0} \leq 1000$ & $\mathrm{t}_{0}>1000$ \\
\hline $\mathrm{t}-\mathrm{t}_{0} \leq 10$ & 40,5 & 23,1 & 11,2 & \\
\hline $10<t-t_{0} \leq 100$ & 25,8 & 23,5 & 21,2 & 40,8 \\
\hline $100<\mathrm{t}-\mathrm{t}_{0} \leq 1000$ & 17,5 & 22,8 & 25,0 & 41,3 \\
\hline $\mathrm{t}-\mathrm{t}_{0}>10$ & 11,6 & 20,5 & 24,7 & \\
\hline
\end{tabular}

Tabela 2.12 - Coeficiente de variação $\omega_{\mathrm{B} 3}$ de diversos modelos de retração para diferentes faixas de duração de secagem em dias (Fonte: BAŽANT; BAWEJA, 2000).

\begin{tabular}{ccccc}
\hline$\omega_{\mathrm{B} 3}$ & $\mathrm{t}_{0} \leq 10$ & $10<\mathrm{t}_{0} \leq 100$ & $100<\mathrm{t}_{0} \leq 1000$ & $\mathrm{t}_{0}>1000$ \\
\hline Modelo B3 & 38,5 & 29,3 & 22,4 & 19,6 \\
Modelo ACl & 67,8 & 50,4 & 43,3 & 44,8 \\
Modelo CEB & 53,5 & 40,2 & 44,7 & 37,4 \\
\hline
\end{tabular}

Almeida (2006) comparou resultados experimentais de Felix (2005) com modelos teóricos da NBR6118 (2003), EC2 (2003), ACI209 (1982), B3 e GL (gráfico 2.17). Os ensaios foram realizados em Portugal em corpos de prova prismáticos $(15 \times 15 \times 50 \mathrm{~cm})$ utilizando classe de cimento $\mathrm{N}$ do EC2 e agregados normais. Os corpos de prova foram mantidos em cura selada até o oitavo dia e os ensaios foram conduzidos com umidade relativa de $54 \%$. Almeida (2006) concluiu que todas as curvas teóricas apresentaram diferenças significativas em relação ao experimental, variando de 25 a $50 \%$. 


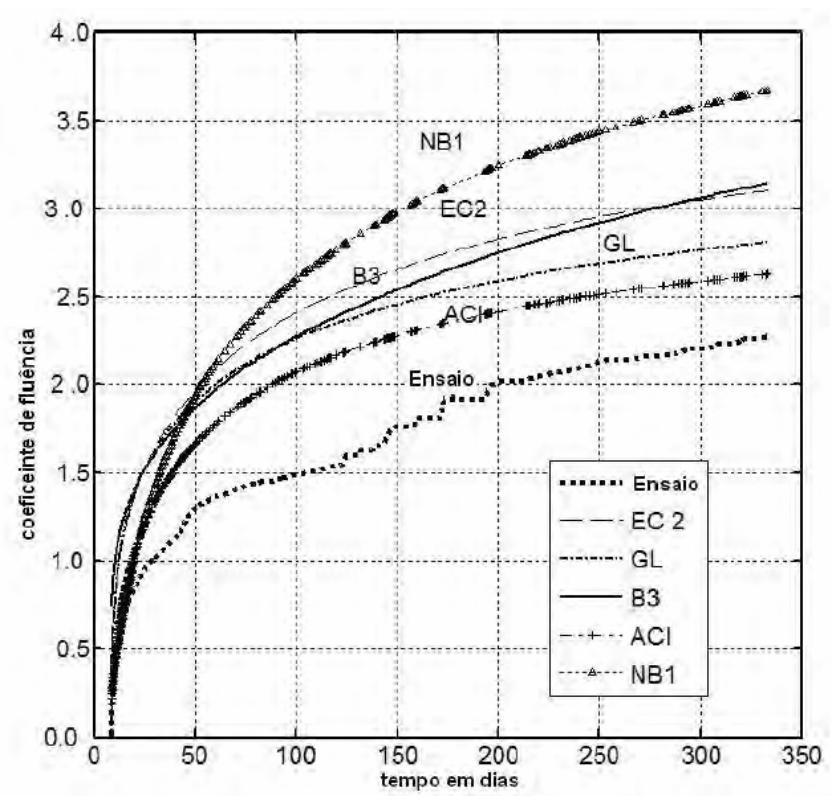

Gráfico 2.17 - Modelos de fluência e resultados experimentais (Fonte: ALMEIDA, 2006).

Sampaio (2004) conclui que a NBR6118 (2003) está desatualizada, pois a caracterização da fluência no concreto é atribuída a materiais com propriedades físicas diferentes dos materiais utilizados atualmente, ou seja, não foi levada em consideração a solução tecnológica no comportamento de tais materiais.

Videla (2006) comparou modelos de retração (ACl209R, 1992, B3, CEB, GL, Sakata, 1993 - SAK1 e Sakata, 2001 - SAK2) utilizando o coeficiente de variação $\omega_{\mathrm{B} 3}$ com diversos concretos Chilenos e sugeriu um modelo de atualização. Os concretos foram mantidos em cura úmida até 7 dias e as deformações de retração por secagem foram medidas de 7 até 1350 dias. Os concretos apresentavam as seguintes características:

- Agregados de origem calcária;

- Agregado com dimensão máxima de 20 e 40 mm;

- Cimento Portland com pozolana;

- Abatimento de 60 e $120 \mathrm{~mm}$;

- Diferentes tipos e dosagens de aditivos.

Videla (2006) concluiu que nenhum modelo consegue prever a evolução e magnitude da retração dos concretos chilenos. O ACl209R (1992) apresenta coeficiente de variação grande $\left(\omega_{\mathrm{B} 3}=52,2 \%\right)$ subestimando as deformações durante todo o período e aumentando ao longo do tempo. O modelo B3 representa bem as deformações dos concretos chilenos a curto prazo, subestimando para idades mais avançadas; o coeficiente de variação é grande $\left(\omega_{\mathrm{B} 3}=41,3 \%\right)$. O CEB e o GL 
superestimam os resultados experimentais a curto prazo, mas subestimam a longo prazo, apresentando coeficiente de variação $\omega_{\mathrm{B} 3}$ de 44,7 e $38,7 \%$, respectivamente. Os modelos do SAK1 e SAK2 são os mais precisos apresentando baixo coeficiente de variação $\omega_{\mathrm{B} 3}$ de 27,5 e $29,9 \%$, respectivamente. Como já era esperado, a curva calibrada do modelo de retração (CA), baseada na função tempo do ACl209R (1992) e na retração última de SAK1, foi a que melhor se ajustou aos resultados experimentais, reforçando a necessidade de validar, calibrar ou atualizar os modelos com os resultados dos ensaios para condições distintas daquelas propostas nos modelos. Os resultados estão apresentados na tabela 2.13.

Goel; Kumar e Paul, 2007 fizeram um estudo comparativo de modelos de previsão de fluência e retração (ACl209, 1982, B3, CEB e GL) e resultados experimentais obtidos em sua pesquisa e pelo RILEM data bank. Foi utilizado cimento ASTMIII, cura úmida até 7 dias e a resistência à compressão variou de 63 a 32,45 MPa. Para comparação foi utilizado o indicador estatístico desvio padrão. Goel; Kumar e Paul (2007) concluíram que o modelo que melhor prevê a fluência e a retração é o $\mathrm{GL}$, se adequando bem aos resultados experimentais, apresentando desvio padrão de 0,021 e 0,018 para 63 e 32,45 MPa, respectivamente. Os modelos do ACl, B3 e CEB subestimam durante todo o período analisado de retração. Para a fluência o $\mathrm{ACl}, \mathrm{B} 3 \mathrm{e}$ o CEB superestimam na maior parte dos casos.

Tabela 2.13 - Comparação do coeficiente de variação $\omega_{\mathrm{B} 3}$ entre diversos modelos de retração e diferentes concretos (Fonte: VIDELA, 2006).

\begin{tabular}{|c|c|c|c|c|c|c|c|c|}
\hline \multirow{2}{*}{\multicolumn{2}{|c|}{ Tipo de concreto }} & \multicolumn{7}{|c|}{ Modelos de previsão de retração por secagem } \\
\hline & & $\mathrm{ACl}$ & B3 & CEB & GL & SAK1 & SAK2 & $\mathrm{CA}$ \\
\hline & Todos concretos & 52,2 & 41,3 & 44,7 & 38,7 & 27,5 & 29,9 & 21,2 \\
\hline & Concreto com aditivo & 56,5 & 36,3 & 40,2 & 42,7 & 31,0 & 34,0 & 27,1 \\
\hline & Concreto sem aditivo & 50,3 & 44,6 & 47,8 & 36,7 & 35,6 & 27,7 & 17,1 \\
\hline \multirow{3}{*}{$\begin{array}{l}\text { Tipo de cimento } \\
\text { (sem aditivo) }\end{array}$} & Cimento Portland & 51,0 & 36,6 & 29,4 & 46,3 & 35,2 & 36,6 & 30,0 \\
\hline & Cimento de pozolana (graúdo) & 62,0 & 35,8 & 52,4 & 43,8 & 20,1 & 24,3 & 18,4 \\
\hline & Cimento de pozolana (miúdo) & 57,9 & 32,9 & 28,1 & 35,5 & 24,4 & 28,5 & 26,0 \\
\hline \multirow{3}{*}{ Tipo de aditivo } & $\begin{array}{l}\text { Plastificante e } \\
\text { superplastificante }\end{array}$ & 65,0 & 52,5 & 53,4 & 34,3 & 19,3 & 31,5 & 15,5 \\
\hline & Expansivo & 56,3 & 47,3 & 52,7 & 43,4 & 15,7 & 26,3 & 13,2 \\
\hline & Redutor de retração & 40,2 & 34,1 & 38,5 & 34,3 & 34,1 & 24,8 & 20,3 \\
\hline
\end{tabular}

No Brasil, apesar de haver diversas pesquisas que estudam as propriedades de fluência e retração em concreto (TAKEUTI, 2003; VELASCO, 2008; KALINTZIS, 
2000; MILLER, 2008), há poucos resultados e praticamente não foram realizados ensaios de fluência por secagem em corpos de prova (FONTANIVE, 1982). A necessidade de realização deste ensaio para caracterização da fluência por secagem é reforçada por Kalintzis (2000).

$\mathrm{Na}$ tabela 2.14 estão apresentadas as características dos estudos encontrados de fluência e retração em corpos de prova. Todos os ensaios de fluência foram feitos a $40 \%$ da resistência à compressão média da idade do carregamento.

Tabela 2.14 - Estudos de caracterização da fluência e retração em corpos de prova no Brasil.

\begin{tabular}{|c|c|c|c|c|c|c|c|}
\hline \multicolumn{2}{|c|}{ Autor } & $\begin{array}{l}\text { Velasco, } \\
2008\end{array}$ & $\begin{array}{c}\text { Takeuti, } \\
2003\end{array}$ & $\begin{array}{l}\text { Kalintzis, } \\
2000\end{array}$ & Miller, 2008 & $\begin{array}{l}\text { Pereira, } \\
2001\end{array}$ & Equipe de Furnas \\
\hline \multicolumn{2}{|c|}{ Tipo de ensaio } & $\mathrm{FB}, \mathrm{RS}, \mathrm{RA}^{*}$ & $\mathrm{FB}, \mathrm{RS}^{*}$ & $\mathrm{FB}, \mathrm{RS}, \mathrm{RA}^{*}$ & $\mathrm{RS}^{*}$ & $\mathrm{FB}^{*}$ & $\mathrm{FB}, \mathrm{RS}^{*}$ \\
\hline \multirow{2}{*}{$\begin{array}{l}\text { Geometria } \\
\text { dos CPs }\end{array}$} & $\begin{array}{l}\text { Fluência } \\
\text { (cm) }\end{array}$ & $\begin{array}{c}15 \times 30 \\
\text { (cilíndrico) }\end{array}$ & $\begin{array}{c}25 \times 50 \\
\text { (cilíndrico) }\end{array}$ & $\begin{array}{c}15 \times 30 \\
\text { (cilíndrico) }\end{array}$ & --- & --- & Variável c/ tensão \\
\hline & $\begin{array}{l}\text { Retração } \\
\text { (cm) }\end{array}$ & $\begin{array}{c}\text { 75x75x60 } \\
\text { (prismático) }\end{array}$ & $\begin{array}{c}\text { 15×15x60 } \\
\text { (prismático) }\end{array}$ & $\begin{array}{c}\text { 15x15x60 } \\
\text { (prismático) }\end{array}$ & $\begin{array}{c}\text { 15×15x60 } \\
\text { (prismático) }\end{array}$ & --- & Variável \\
\hline \multicolumn{2}{|c|}{ Idade Carregamento (dias) } & 28 & $7,14,50,103$ & $3,7,28,90$ & --- & $7,28,90,180$ & $3,7,28,90,365$ \\
\hline \multicolumn{2}{|c|}{ Início Secagem (dias) } & 28 & 28 & 28 & --- & --- & 3,7 \\
\hline \multicolumn{2}{|c|}{ Tipo de cimento } & CPIII40 & $\begin{array}{l}\text { CPIIF32 } \\
\text { CPV }\end{array}$ & CPIIF32 & CPII & CPI32 & $\begin{array}{l}\text { Escória,pozolana, } \\
\text { cinza volante,sílica }\end{array}$ \\
\hline \multicolumn{2}{|c|}{ Condições de ensaio } & $21^{\circ} \mathrm{C} 50 \%$ & $23^{\circ} \mathrm{C} 60 \%$ & $23^{\circ} 50 \%$ & $\begin{array}{l}15 \text { a } 40^{\circ} \mathrm{C} \\
20 \text { a } 80 \%\end{array}$ & --- & $23^{\circ} \mathrm{C} 60 \%$ \\
\hline
\end{tabular}

*FB - fluência básica; FS - fluência por secagem; RA - retração autógena; RS - retração por secagem.

É interessante notar que a maior parte dos estudos encontrados na literatura nacional analisa a fluência e retração de concretos especiais. Além disso, os ensaios de fluência e retração realizados não adotam um padrão. Por exemplo, há variação da geometria dos corpos de prova analisados com mesmo tamanho de agregado máximo, característica que influencia consideravelmente nas deformações de retração e fluência por secagem. Staquet e Espion (2001) verificaram que a dispersão dos resultados experimentais de diversos laboratórios é considerável, mesmo adotando procedimento padrão e composição idêntica dos materiais. Embora, Bažant et al. (1987) afirme que o coeficiente de variação para medidas de retração de uma mesma betonada seja de apenas $8 \%$.

Velasco (2008) caracterizou a fluência básica e retração autógena e por secagem para concretos reforçados com fibras. Takeuti (2003) apenas caracterizou a fluência básica e a retração por secagem de concretos de alto desempenho. Nos gráficos $2.18 \mathrm{a}$ e $2.18 \mathrm{~b}$ estão apresentados os resultados do concreto convencional de referência. 


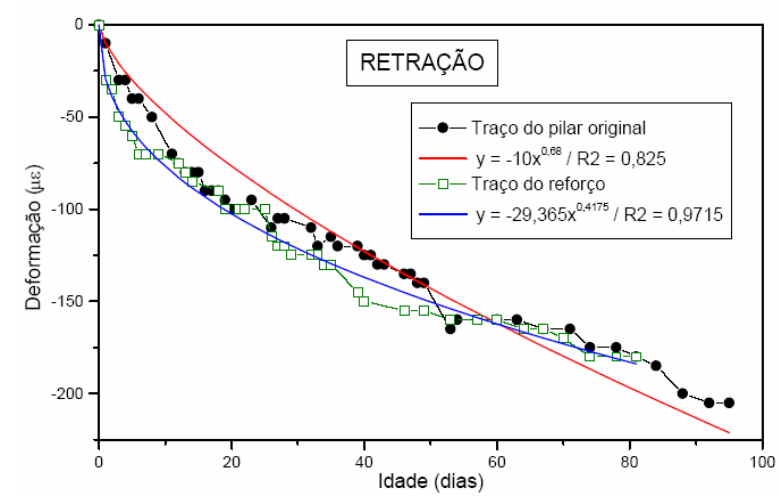

a) Deformação por retração.

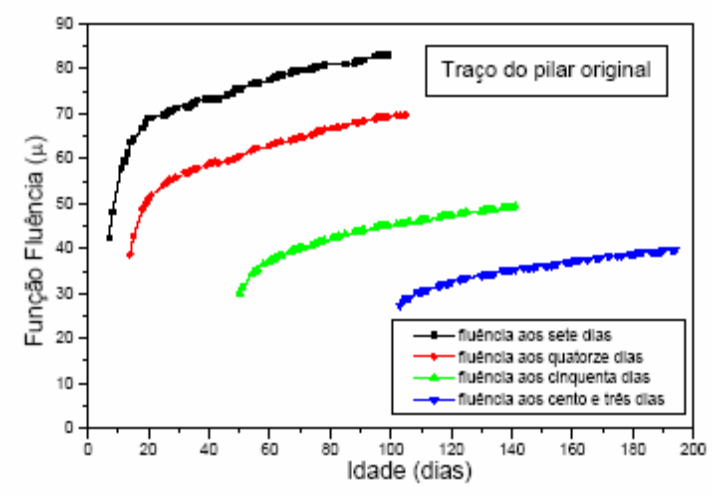

b) Deformação por fluência.

Gráfico 2.18 - Deformação por fluência e retração do concreto (Fonte: TAKEUTI, 2003).

Kalintzis (2000) também estudou concreto de alto desempenho caracterizando a fluência básica e a retração autógena e por secagem.

Miller (2008) desenvolveu sua pesquisa analisando a retração por secagem de concreto com fibras de aço. O gráfico 2.19 apresenta resultados experimentais de retração por secagem obtida para o concreto de referência (convencional) estudado e os resultados de previsão da NBR6118 (2003) e do ACl209 (1982). A partir dos resultados Miller (2008) conclui que o $\mathrm{ACl}$ é o modelo que melhor prevê os resultados de retração.

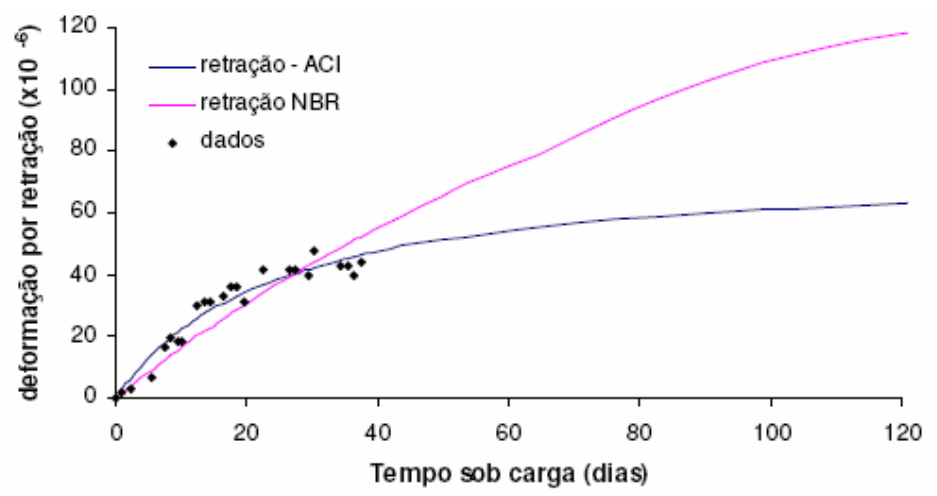

Gráfico 2.19 - Deformação de retração por secagem do concreto (Fonte: MILLER, 2008).

Pereira (2001) caracterizou concreto massa e estrutural para fluência básica. A partir dos resultados, concluiu que a fluência aumenta com a diminuição do tamanho máximo do agregado graúdo e da idade de carregamento. Além disso, verificou que a fluência é maior para agregado graúdo de basalto do que de cascalho.

Equipe de Furnas (1997) publicou resultados de concretos convencionais e compactado com rolo. São apresentados diversos resultados de concreto massa e estrutural de fluência básica e retração por secagem e autógena. 


\subsection{Calibração da fluência do modelo B3}

Bažant (2001) propôs um método para calibração do modelo B3 de fluência a partir de resultados experimentais de curto prazo. De acordo com Bažant (2001), este método pode ser utilizado para análise de estruturas com nível de sensibilidade 5 , ou seja, que exigem grande precisão da previsão por se tratar de estruturas de grande porte, tais como: pontes com grande vãos, containeres nucleares, grandes estruturas offshore. Também reforça a necessidade de reduzir erros derivados da composição e resistência do concreto, eliminando a verificação da eficiência do modelo. Ojdrovic e Zarghamee (1996) afirmam que é possível prever a fluência com resultados de 28 dias. Entretanto, asseguram que resultados experimentais de fluência obtidos logo após o carregamento e utilizados para prever as deformações resultam em erros consideráveis. Carreira e Burg (2000) acreditam que um período mínimo de 91 dias de ensaio de fluência é necessário para atualizar modelos de previsão. Afirma também que a precisão do modelo é maior de acordo com o aumento do período medido.

A calibração do modelo é feita ajustando a função $F\left(t, t_{0}\right)$ por meio da utilização dos parâmetros $p_{1}$ e $p_{2}$ dependentes dos resultados experimentais. A função $F\left(t, t_{0}\right)$ é dada pela eq.(2-114):

$F\left(t, t_{0}\right)=C_{0}\left(t, t_{0}\right)+C_{d}\left(t, t_{0}, t_{s}\right)$

$C_{0}\left(t, t_{0}\right)$ - fluência específica básica $\left(\times 10^{-6} / \mathrm{MPa}\right)$

$C_{d}\left(t, t_{0}\right)$ - fluência específica por secagem (x10-6/MPa)

O ajuste do modelo B3 é dado pela eq.(2-115):

$J\left(t, t_{0}\right)=p_{1}+p_{2} \cdot F\left(t, t_{0}\right)$

$J\left(t, t_{0}\right)$ - fluência específica do modelo B3 (x10-6/MPa)

Os parâmetros $p_{1}$ e $p_{2}$ são obtidos a partir da equação de regressão linear dados pelas eq.(2-116) e eq.(2-117):

$p_{2}=\frac{n \sum\left(F_{i} J_{i}\right)-\left(\sum F_{i}\right) \cdot \sum\left(F_{i} J_{i}\right)}{n \sum\left(F_{i}^{2}\right)-\left(\sum F_{i}\right)^{2}}$ 
$p_{1}=\bar{J}-p_{2} \cdot \bar{F}$

$\bar{J}$ - média de todos os resultados experimentais $\mathrm{J}_{\mathrm{i}}$ medidos

$\bar{F}$ - média de todos os correspondentes valores de $\mathrm{F}_{\mathrm{i}}$ obtidos do modelo B3

$J_{i}$ - resultados experimentais medidos

$F_{i}$ - função da fluência específica dada pelo modelo B3

Esta calibração corresponde à substituição dos coeficientes $q_{1}, q_{2}, q_{3}, q_{4}$ e $q_{5}$ calculados pelo modelo $\mathrm{B} 3$, obtendo-se os valores corrigidos dados por $q^{*}{ }_{1}=p_{1} \cdot q_{1}$ $q *_{2}=p_{2} \cdot q_{2}, q *_{3}=p_{2} \cdot q_{3}, q *_{4}=p_{2} \cdot q_{4}$ e $q *_{5}=p_{2} \cdot q_{5}$.

Bažant (2001) calibrou o modelo B3 utilizando o método proposto a partir de resultados experimentais de fluência básica, como pode ser visto no gráfico 2.20. Nesta calibração foram utilizados apenas cinco resultados experimentais para os primeiros 28 dias medidos, representados por círculos em negrito.

Comparando a previsão calibrada com a previsão feita apenas com a formulação é possível notar que a curva calibrada ajustou aos resultados experimentais até 1000 dias.

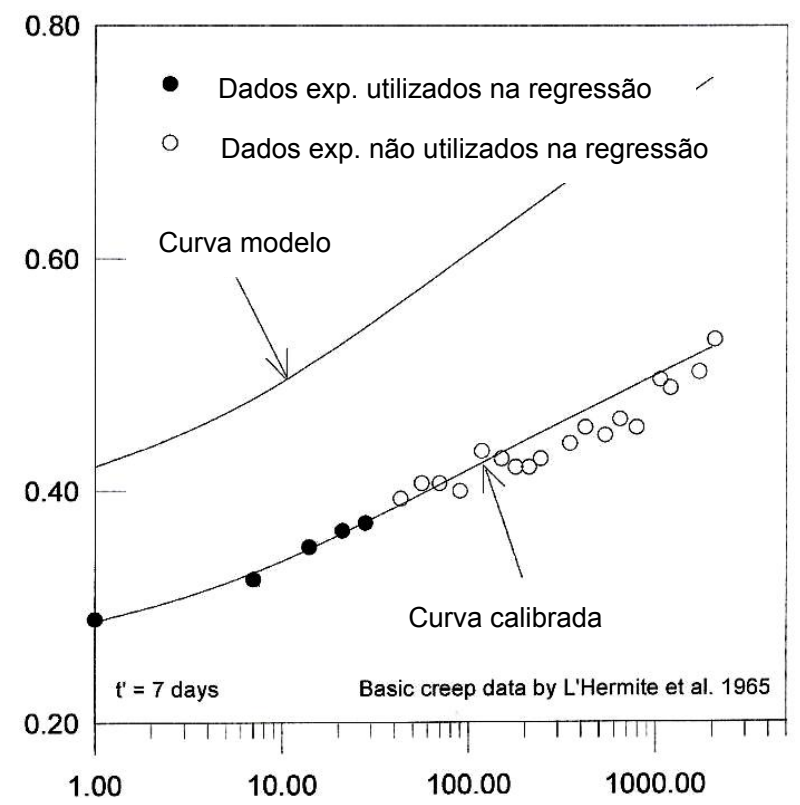

Gráfico 2.20 - Exemplo de calibração da fluência do modelo B3 (fonte: Bažant, 2001). 


\subsection{Fluência e retração em pilares de concreto armado}

Neste item são apresentadas pesquisas realizadas em protótipos de pilares considerando o efeito de fluência e retração, assim como modelos de previsão de transferência de carga do concreto para armadura.

\subsubsection{Pesquisas precedentes}

A fluência e a retração em elementos de concreto armado pode alterar as tensões internas de duas maneiras: reduzindo as tensões existentes (concreto protendido) ou criando novas tensões quando materiais com diferentes características (concreto + armadura) interagem numa dada seção transversal (RÜSCH, 1983).

No início do processo, tensões internas são causadas basicamente pela mudança de volume não uniforme, por exemplo, devido ao calor de hidratação gerado durante o processo de hidratação do concreto ou, posteriormente, pelo processo de retração. No dimensionamento de estruturas de concreto armado, estas tensões iniciais são desconsideradas. Em geral, estas tensões oferecem risco somente no momento em que iniciam, pois são reduzidas rápida e acentuadamente pela fluência. É importante ressaltar que estas tensões desenvolvem-se lentamente e são pequenas. Por esta razão, há a necessidade de proteger o concreto fresco da secagem rápida. Esta é a única maneira de prevenir que os desenvolvimentos das tensões de tração gerados sejam menores que o da resistência à tração do concreto, evitando o surgimento de fissuras (RÜSCH, 1983).

Em pilares de concreto armado, além das tensões internas iniciais, há o efeito da fluência que causa contração do concreto. Pela hipótese de que as seções planas permanecem planas após o carregamento para pequenas deformações, as tensões decrescem no concreto ao longo do tempo e aumentam na armadura. A mesma redistribuição é produzida pela retração. Os esforços internos gerados pela retração são, em termos, reduzidos pela fluência. Como resultado da redistribuição causada pela fluência e retração, a armadura em pilares subarmados pode 
alcançar o ponto de escoamento, mesmo sob cargas em serviço (RÜSCH, 1983, TROXELL et al. apud FINTEL; KHAN, 1969). Neste sentido, é fundamental avaliar o fenômeno de transferência de carga em pilares de concreto armado devido à fluência e retração do concreto. Takeuti (2003) também verificou a partir dos resultados experimentais de pilares em concreto armado que as restrições de deformação introduzidas pela armadura devem ser consideradas, pois afetam consideravelmente as deformações das armaduras.

Apesar da NBR6118 (2004) especificar a análise da fluência apenas para pilares com esbeltez $\lambda>90$, nesta pesquisa é estudado a propriedade da fluência em pilares curtos, pois o objetivo principal é analisar a transferência de carregamento do concreto para a armadura.

Na década de 30 , diversos pesquisadores estudaram sobre a fluência e retração de pilares em concreto armado (DAVIS; DAVIS, 1931; RICHART; STAEHLE, 1932; SLATER; LYSE, 1931; RICHART; STAEHLE, 1931 e LYSE; KREIDLER, 1932) no esforço de colaborar com o Report of Committe $105 \mathrm{ACl}$. Desde então, foram desenvolvidos diversos trabalhos sobre o assunto (HOLM; PISTRANG, 1966; ZIEHL; CLOYD; KREGER, 2004; CLAESON; GYLLTOFT, 2000 e SALAU, 2001).

No Brasil, apesar de haver muitos estudos experimentais em pilares de concreto convencional (ADORNO, 2004; ARAÚJO, 2004; RAMOS, 2001; OLIVEIRA, 2004 e VALLADARES, 1997), tratam-se de pesquisas que avaliam a capacidade última de pilares. São escassos os estudos envolvendo as propriedades de fluência e retração em pilares de concreto convencional armado (COSTA NETO, 2004 e TAKEUTI, 2003).

A seguir são apresentados alguns resultados experimentais e analíticos de fluência e retração em pilares de concreto armado obtidos por diversos autores. Um resumo das características dos pilares estudados à fluência e retração por estes autores está apresentado na tabela 2.15. 
Tabela 2.15 - Características dos pilares ensaiados à fluência e retração.

\begin{tabular}{|c|c|c|c|c|c|c|}
\hline \multirow[b]{2}{*}{ Autor } & \multirow{2}{*}{$\begin{array}{l}\text { Seção transversal } \\
\text { (Dimensões - cm) }\end{array}$} & \multirow{2}{*}{$\begin{array}{c}\text { Data de } \\
\text { carregamento } \\
\text { (dias) }\end{array}$} & \multirow{2}{*}{$\begin{array}{l}\text { Duração do } \\
\text { ensaio }\end{array}$} & \multirow{2}{*}{$\begin{array}{c}\text { Tensão } \\
\text { aplicada (\%) }\end{array}$} & \multicolumn{2}{|c|}{ Armadura } \\
\hline & & & & & $\begin{array}{c}\text { Long. } \\
(\%)\end{array}$ & Trans. \\
\hline Takeuti, 2003 & $\begin{array}{c}\text { Quadrada } \\
(12 \times 12 \times 90) \\
\text { Circular }(12 \times 90)\end{array}$ & $\begin{array}{l}\text { Várias idades } \\
\qquad(9 \text { a 20) }\end{array}$ & 50 a 80 dias & $\begin{array}{l}\text { Várias tensões } \\
\qquad(29 \text { a 86) }\end{array}$ & 1,4 e 3,5 & $\begin{array}{l}\phi 6,3 \\
c / 410\end{array}$ \\
\hline $\begin{array}{l}\text { Richart; Staehle, } 1931 \\
\text { Slater; Lyse, } 1931 \\
\text { Lyse; Kreidler, } 1932\end{array}$ & $\begin{array}{l}\text { Circular } \\
(20 \times 152)\end{array}$ & 56 & 20 semanas & 9 e 15 & 1,54 e 6 & $\begin{array}{c}1,24 \text { e } \\
1,2 \%\end{array}$ \\
\hline $\begin{array}{l}\text { Holm, T.; Pistrang, J., } \\
1966\end{array}$ & $\begin{array}{c}\text { Quadrada } \\
(25 \times 25 \times 137)\end{array}$ & 28 & 12 meses & 35 & 3,1 & $\phi 1 \mathrm{c} / 38$ \\
\hline $\begin{array}{l}\text { Ziehl; Cloyd; Kreger } \\
2004\end{array}$ & Circular (20x120) & $\begin{array}{l}\text { Várias idades } \\
\qquad(15 \text { a 25) }\end{array}$ & $\begin{array}{l}15 \text { a } 18 \\
\text { meses }\end{array}$ & 40 & $\begin{array}{c}0,360,54 \\
\text { e } 0,72\end{array}$ & $\phi 3 c / 5$ \\
\hline Davis; Davis, 1931 & Circular $(25 \times 50 \mathrm{~cm})$ & 60 & 18 meses & 15 & 1,9 & $1,33 \%$ \\
\hline Costa Neto, 2004 & $\begin{array}{c}\text { Retangular } \\
(12,5 \times 15 \times 210)\end{array}$ & 189 & 27 dias & 80 & 0,4 e 4 & $\begin{array}{r}\phi 5 \mathrm{c} / 6 \\
\phi 5 \mathrm{c} / 12\end{array}$ \\
\hline Claeson; Gylltoft, 2000 & $\begin{array}{l}\text { Retangular } \\
(20 \times 20 \times 400)\end{array}$ & $\begin{array}{c}\text { Várias idades } \\
\qquad 28 \text { a } 203\end{array}$ & 22 dias & 60 & 2 & $\phi 8 \mathrm{c} / 13$ \\
\hline
\end{tabular}

Richart e Staehle (1931), Slater e Lyse (1931), Lyse e Kreidler (1932) concluíram, após vários ensaios em pilares de concreto armado, que a maior parte das deformações por fluência e retração ocorre de 2 a 4 semanas; a variação da taxa de estribos teve efeito desprezível na fluência e retração, embora à fluência para pilares sem estribo seja maior; não foi observado escoamento das armaduras longitudinais e o pilar com menor taxa de armadura longitudinal demonstrou maior mudança nas tensões das armaduras.

Holm e Pistrang (1966) concluíram que depois de 1 ano, aproximadamente 44\% das tensões do concreto do pilar foram transferidas para a armadura. Em sua pesquisa também foi feito um estudo do efeito de escala entre pilares e diversos corpos de prova, considerando fluência e retração. Primeiramente, foram comparados resultados de deformações por fluência e retração de corpos de prova cilíndricos $(15 \times 30 \mathrm{~cm})$ e de pilares de seção quadrada $(25 \times 25 \times 137 \mathrm{~cm})$. A partir dos resultados (gráfico 2.21), foi possível concluir que as deformações por fluência e retração do pilar foram $51 \%$ das deformações medidas nos corpos de prova. Em seguida, foi feita uma comparação entre as deformações por retração livre de pilares em concreto armado com seção quadrada $(25 \times 25 \times 45 \mathrm{~cm})$ e corpos de 
provas com seção circular $(15 \times 30 \mathrm{~cm})$. Esta última comparação foi realizada, pois foi verificado que as relações superfície volume para os corpos de prova cilíndricos $(15 \times 30 \mathrm{~cm})$ e o pilar $(0,67$ e 0,40 , respectivamente) eram muito distintas. Este fato resultaria em medidas de deformações por retração não comparáveis. A partir das deformações dos corpos de prova com seção quadrada e retangular obteve-se uma relação volume superfície de 0,8.

Fintel e Khan (1969) afirmam que resultados experimentais de fluência e retração não podem ser comparados com pilares de outras geometrias sem considerar o efeito de forma.

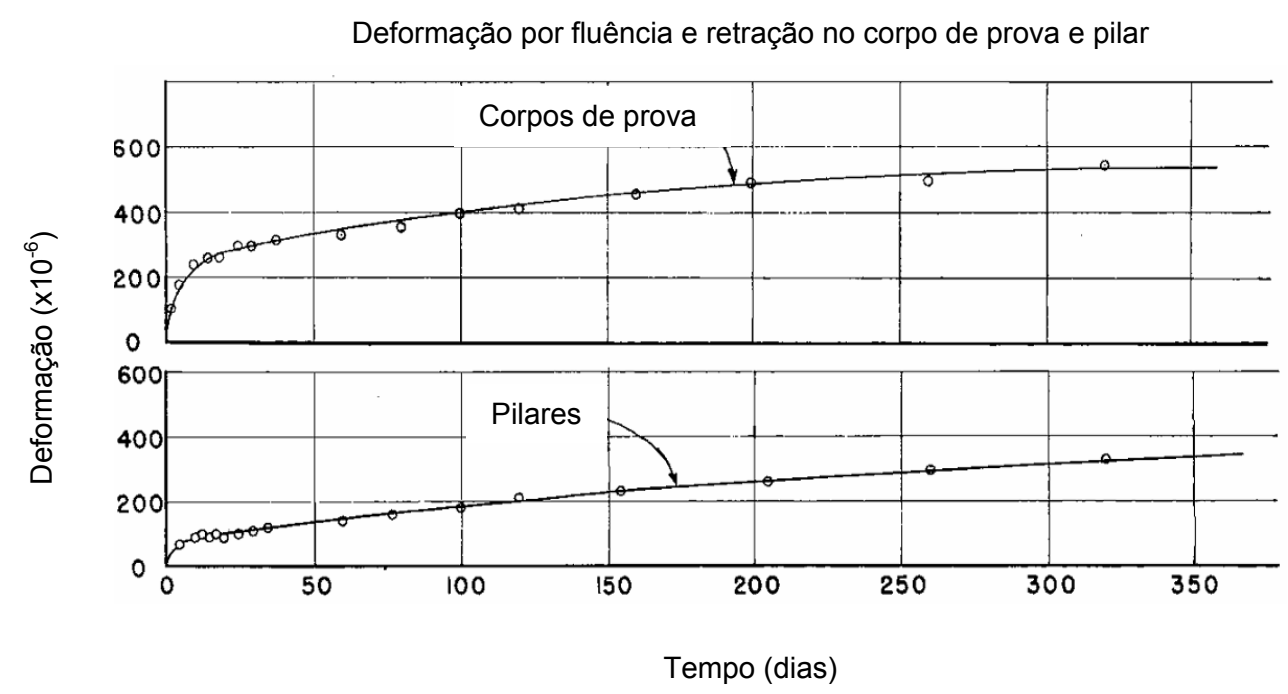

Gráfico 2.21 - Deformações por fluência e retração no corpo de prova e pilar (Fonte: HOLM; PISTRANG, 1966).

Ziehl; Cloyd e Kreger (2004) ensaiaram diversos pilares em concreto armado à fluência e retração e comparou os resultados experimentais com aqueles obtidos analiticamente a partir do ACI209R (1992) considerando a restrição da armadura às propriedades analisadas. Os resultados experimentais e analíticos dos pilares estão apresentados nos gráficos 2.19 e 2.20. Nas legendas destes gráficos, estão apresentadas as nomenclaturas designadas para cada pilar. A letra indica o tipo de carregamento (concêntrico - $C$, excêntrico - $E$ ou descarregado - $U$ ); o número que precede representa a resistência do concreto em psi (4000 psi - $27 \mathrm{MPa}$ ou 8000 psi - $55 \mathrm{MPa}$ ); em seguida dois dígitos indicam a taxa de armadura longitudinal em porcentagem e, por último, um único dígito especifica a numeração do corpo de prova de um mesmo grupo. Um exemplo da nomenclatura utilizada é dado por: 


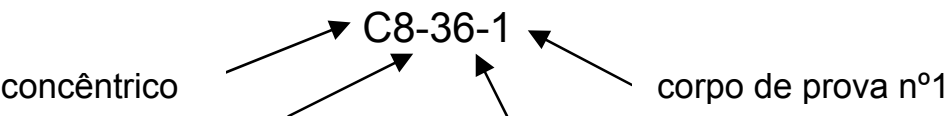

resist. compressão de 8000 psi (55MPa) taxa de armadura long. de $36 \%$

Ziehl; Cloyd e Kreger (2004) concluíram que o método do ACl209 (1982), para determinação da transferência de carregamento do concreto para a armadura devido às propriedades de fluência e retração, demonstrou ser eficiente (gráficos 2.22 e 2.23). Como ele reduziu a armadura mínima permitida pelo ACl318 (2003) observou que quase todos os pilares superaram a deformação de escoamento, principalmente os concreto com $55 \mathrm{MPa}$.

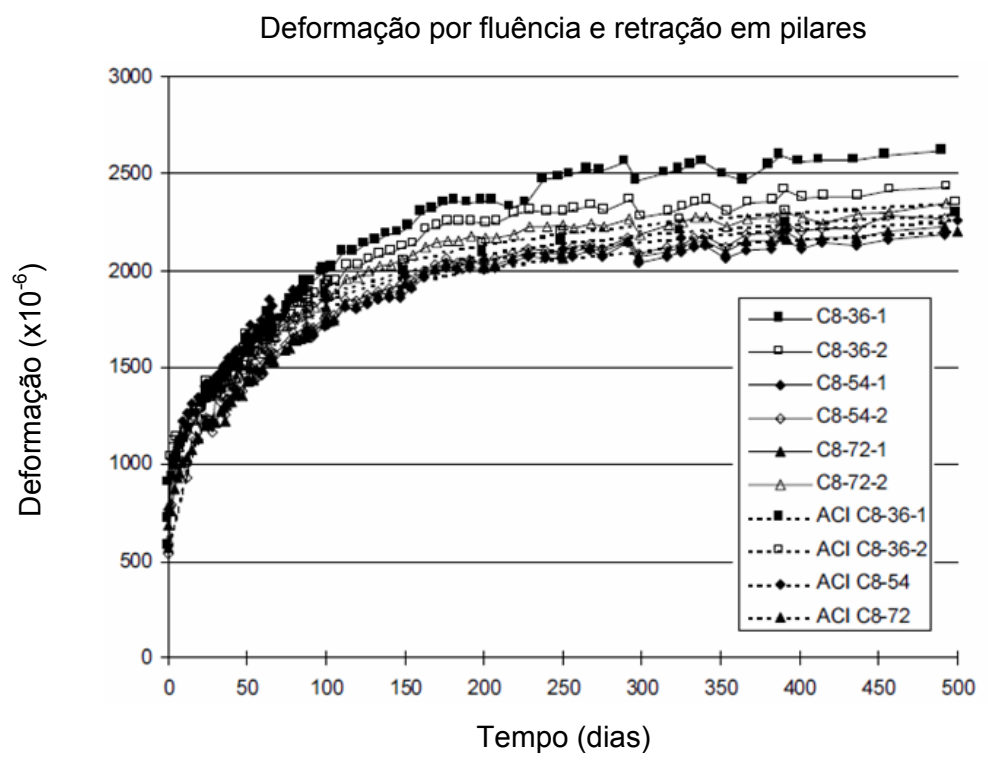

Gráfico 2.22 - Deformações por fluência e retração no corpo de prova e pilar (Fonte: ZIEHL; CLOYD; KREGER, 2004).

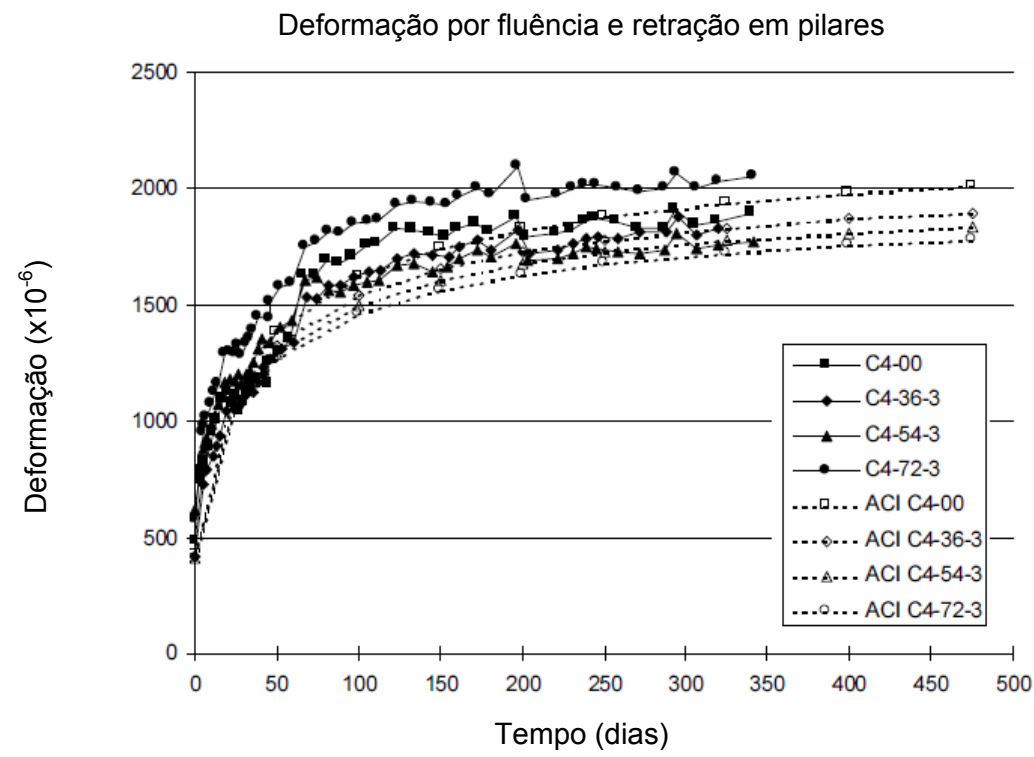

Gráfico 2.23 - Deformações por fluência e retração no corpo de prova e pilar (Fonte: ZIEHL; CLOYD; KREGER, 2004). 
Davis e Davis (1931) também observaram que, aos 18 meses de idade do concreto sob carga constante, as deformações por fluência e retração de pilares não armados e armados foram 6 e 4 vezes maior que a deformação instantânea, respectivamente. Além disso, concluiu que as tensões no concreto reduziram $38 \%$ para uma taxa de armadura longitudinal de 1,9\%.

Considerando três taxas de armadura longitudinal (1,5, 4 e $6 \%)$ foi observado por Slater e Lyse (1931) e Lyse e Kreidler (1932) que até 4 semanas, a retração foi praticamente à mesma. Após este período, a retração foi maior para pilares com menor taxa de armadura e, insignificante, para os pilares com maior taxa de armadura. Lyse e Kreidler (1932) também concluíram que após o descarregamento dos pilares, não foi notado fissuras.

Costa Neto (2004) analisou pilares sob tensão de $80 \%$ da resistência última da data do carregamento e concluiu que para este nível de carregamento o efeito da fluência pode levar a ruptura. Este fato foi comprovado por Claeson e Gylltoft (2000) que verificaram, após cinco dias de carregamento, o aparecimento de fissuras devido à tensão de tração nos pilares de concreto armado, ou seja, fluência não linear e ruptura após 22 dias de carregamento. Costa Neto (2004) verificou que, para o nível de tensão de $80 \%$, a fluência pode levar o pilar à ruptura, como pode ser visto no gráfico 2.24 .

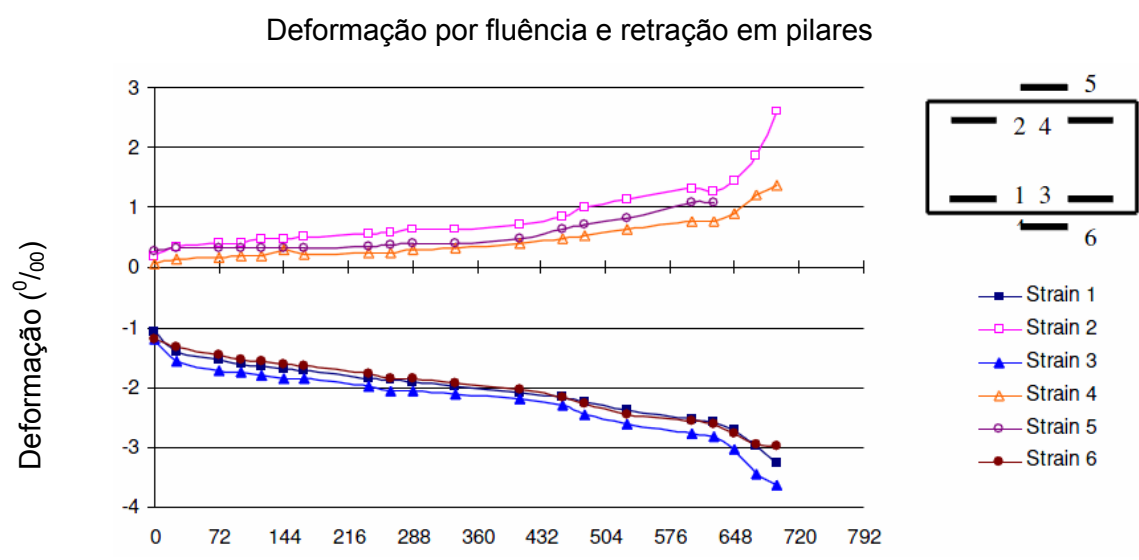

Tempo (horas)

Gráfico 2.24 - Deformações por fluência e retração em pilares (Fonte: COSTA NETO, 1998). 
Takeuti (2003) verificou que tanto as deformações somente por retração quanto de fluência e retração dos pilares analisados foi inferior aos resultados obtidos pela NBR6118 (2002).

\subsubsection{Modelos de previsão da fluência e retração em pilares}

Muitas pesquisas que estudam as deformações ao longo do tempo no concreto têm sido conduzidas com o objetivo de determinar o mecanismo e parâmetros experimentais das propriedades de fluência e retração em corpos de prova. Entretanto, também é importante determinar a restrição destas deformações pela armadura nos elementos estruturais, assim como verificar a validade da caracterização destas propriedades em corpos de prova para elementos estruturais, visto que os modelos de previsão são calibrados com resultados de corpos de prova. Além disso, este estudo também pode fornecer, por exemplo, subsídios para determinação de carregamento para remoção de pilares centrais e, conseqüentemente, reforço de pilares adjacentes (CASTRO, 2008).

Neste sentido, este item tem como objetivo apresentar modelo de previsão de tensões devido à fluência e retração em pilares a partir de resultados de corpos de prova (HOLM; PISTRANG 1966). Também é analisado um modelo que prevê as deformações de pilares a partir de modelos de previsão das deformações ao longo do tempo disponíveis na literatura (ZIEHL; CLOYD; KREGER, 2004).

É importante enfatizar que estes modelos que prevêem a transferência de carregamento a partir de resultados de corpos de prova, são modelos simplificados que não leva em consideração um estudo mais aprofundado de escala.

\subsubsection{Holm e Pistrang (1966)}

O modelo de Holm e Pistrang (1966) é baseado no método determinístico, ou seja, está focado na obtenção da "melhor estimativa" das deformações, produzindo uma estimativa pontual das tensões e deformações. 
As tensões elásticas no concreto $\left(f_{0}\right)$ e na armadura $\left(f_{s}\right)$ a que o pilar está submetido são determinadas pelas eq.(2-118) e eq.(2-119):

$f_{0}=\frac{P}{A[1+(n-1) p]}$

$f_{s}=n f_{0}$

$f_{0}$ - tensão elástica no concreto (MPa)

$f_{s}$ - tensão elástica na armadura (MPa)

$P$ - carregamento que o pilar está submetido $(\mathrm{N})$

$A$ - área da seção transversal do pilar $\left(\mathrm{mm}^{2}\right)$

$E_{s}$ - módulo de elasticidade do aço (MPa)

$E_{c}$ - módulo de elasticidade do concreto (MPa)

$p$ - taxa de armadura longitudinal

$n$ - relação entre módulo de elasticidade da armadura e módulo de elasticidade do concreto dado pela eq.(2-120):

$n=\frac{E_{s}}{E_{c}}$

A fluência específica $(c)$ dos corpos de prova cilíndricos é dada pela eq.(2-121):

$c=\frac{\varepsilon_{c}}{f_{c y l}}$

c - fluência específica dos corpos de prova (x10-6/MPa)

$\varepsilon_{C}$ - deformação por fluência dos corpos de prova

$f_{c y l}$ - tensão nos corpos de prova (MPa)

Para obter a fluência específica $\left(c_{a d j}\right)$ e a deformação por retração $\left(s_{a d j}\right)$ para o pilar é necessário determinar um coeficiente que correlaciona a geometria entre os corpos de prova e o pilar, pelas eq.(2-122) e eq.(2-123):

$c_{a d j}=\alpha \cdot c$

$s_{a d j}=\alpha \cdot s$

Este coeficiente é determinado experimentalmente. Para Holm e Pistrang (1966) este coeficiente é de 0,8.

$c_{\text {adj }}$ - fluência específica ajustada pelo coeficiente de geometria (x10-6/MPa) 
$S_{a d j}$ - deformação por retração ajustado pelo coeficiente de geometria $\left(\times 10^{-6}\right)$

$s$ - deformação por retração dos corpos de prova $\left(\times 10^{-6}\right)$

$\alpha$ - coeficiente de forma e tamanho

A redução de tensão no concreto $\left(f_{t}\right)$ devido à retração pode ser representada pela eq.(2-124):

$f_{t}=\frac{n \cdot p \cdot s \cdot E_{c}}{1+(n-1) \cdot p}$

$f_{t}-$ redução de tensão no concreto devido à retração (MPa)

A tensão final no concreto $\left(f_{f c}\right)$ é expressa pela eq.(2-125):

$f_{f c}=\frac{f_{0}-f_{t}}{e^{\left(f_{f c} / f_{0}\right) \cdot\left(c_{a d j} / b\right)}}$

$f_{f c}-$ tensão final no concreto (MPa)

O coeficiente $b$ é dado pela eq.(2-126):

$b=\frac{1}{E_{c}}\left[\frac{1+(n-1) \cdot p}{n \cdot p}\right]$

Como a tensão final no concreto $\left(f_{f}\right)$ é uma variável ligada, há necessidade de realizar um processo iterativo de convergência.

O carregamento no concreto $\left(P_{c}\right)$ pode ser determinado pela e eq.(2-127):

$P_{c}=A \cdot f_{f}$

$\mathrm{f}_{\mathrm{f}}$ - tensão final no concreto dada pela eq.(2-128):

$$
f_{f}=\frac{f_{0}-f_{t}}{e^{\left(f_{f} / f_{0}\right) \cdot(c / b)}}
$$

Como $f_{f}$ é uma variável que depende dela mesma, é necessário realizar um processo iterativo de convergência para encontrar a solução.

A tensão no aço $\left(f_{s}\right)$ e a variação de tensão no concreto $\left(\Delta f_{c}\right)$ são dadas pelas eq.(2-129) e eq.(2-130):

$$
\begin{aligned}
& f_{s}=n \cdot f_{0} \\
& \Delta f_{c}=f_{0}-f_{f}
\end{aligned}
$$


$\Delta f_{c}$ - variação de tensão no concreto (MPa)

Conseqüentemente, a variação de tensão na armadura $\left(\Delta f_{s}\right)$ é dada pela eq. $(2-131)$ :

$\Delta f_{s}=\Delta f_{c} \frac{1-p}{p}$

$\Delta f_{s}$ - variação de tensão na armadura (MPa)

Portanto, a tensão final do aço $\left(f_{f s}\right)$ é dada pela eq.(2-132):

$f_{f s}=f_{s}+\Delta f_{s}$

$f_{f s}-$ tensão final no aço (MPa)

De acordo com Holm e Pistrang (1966) o resultado obtido pela previsão da transferência de carregamento do concreto para armadura utilizando o método determinístico proposto conseguiu prever o comportamento dos pilares.

\subsubsection{Ziehl; Cloyd e Kreger (2004)}

Ziehl; Cloyd e Kreger (2004) obtiveram a carga remanescente no concreto determinando o coeficiente de fluência e deformação por retração a partir do ACI209R (1992), ou seja, não há necessidade de utilizar resultados experimentais.

Primeiramente, é definida a previsão da deformação inicial e por fluência $\left(\varepsilon_{i}+\left(\varepsilon_{c r e e p}\right)_{t}\right)$ devido à força axial utilizando a seção homogeneizada dada pela eq.(2-133):

$\varepsilon_{i}+\left(\varepsilon_{\text {creep }}\right)_{t}=\frac{P}{\left[A_{g} \cdot\left(1-\rho_{g}\right)+\eta_{\text {eff }} \cdot \rho_{g} \cdot A_{g}\right] \cdot E_{\text {eff }}}$

$\varepsilon_{i}$ - deformação inicial

$\left(\varepsilon_{\text {creep }}\right)_{t}$ - deformação por fluência

$P$ - carga atuante $(\mathrm{N})$

$A_{g}$ - área da seção transversal do pilar $\left(\mathrm{mm}^{2}\right)$

$\rho_{g}-$ taxa de armadura longitudinal 
$\eta_{\text {eff }}$ - relação modular na idade considerada após o carregamento definido pela eq. (2-134):

$\eta_{\text {eff }}=\frac{E_{s}}{E_{\text {eff }}}$

$E_{s}$ - módulo de deformação da armadura ( $\left.\mathrm{MPa}\right)$

$E_{\text {eff }}$ - módulo efetivo do concreto (MPa) dado pela eq.(2-135):

$E_{\text {eff }}=\frac{E_{c i}}{\left(1+v_{t}\right)}$

$E_{c i}$ - módulo de deformação inicial (MPa)

$v_{t}$ - coeficiente de fluência na idade considerada obtida a partir do modelo de fluência (ACIR209, 1992)

A deformação por retração considerando a restrição pela armadura ( $\left.\varepsilon_{\text {shrinkage }}\right)$ pode ser escrita pela eq.(2-136):

$\left(\varepsilon_{\text {shrinkage }}\right)=\left(\varepsilon_{\text {sh }}\right)_{t}-\frac{\left(\varepsilon_{\text {sh }}\right)_{t} \cdot E_{s} \cdot A_{g} \cdot \rho_{g}}{\left(A_{c} \cdot\left(1-\rho_{g}\right)+A_{g} \cdot \rho_{g} \cdot n_{\text {eff }}\right) \cdot E_{\text {eff }}}$

$\left(\varepsilon_{s h}\right)_{t}$ - deformação por retração na idade considerada obtida a partir do modelo

A deformação total no concreto na data considerada, levando em conta a taxa de armadura $\left(\left(\varepsilon_{\text {total }}\right) t\right)$ é expressa pela eq. $(2-137)$ :

$\left(\varepsilon_{\text {total }}\right)_{t}=\left[\varepsilon_{\text {inicial }}+\left(\varepsilon_{\text {creep }}\right)_{t}\right]+\left(\varepsilon_{\text {shrinkage }}\right)_{t}$

Ziehl; Cloyd e Kreger (2004) concluíram que a previsão das deformações por fluência e retração utilizando o modelo do ACI209R (1992) concorda de forma razoável com os resultados experimentais, mas tendem a subestimar as deformações ao longo do tempo. 


\section{CAPÍTULO 3}

\section{ANÁLISE PARAMÉTRICA DOS MODELOS ESTUDADOS}

A verificação da sensibilidade dos modelos com relação aos parâmetros individuais permite avaliar as variáveis que mais influem em cada modelo e controlar em laboratório os parâmetros que sofrem maiores alterações. Entretanto, alguns parâmetros são intrínsecos (quantidade de cimento, água e agregado), pois estão embutidos no traço do concreto e não podem ser isolados. Portanto, estes parâmetros não são verificados na análise paramétrica. De acordo com Howells; Lark e Barr (2005) é muito difícil isolar apenas um parâmetro nos modelos.

Neste item, está apresentada a análise paramétrica dos modelos estudados nesta pesquisa ( $\mathrm{ACl}, \mathrm{EC2}, \mathrm{B} 3, \mathrm{GL}$ e NBR) considerando como variáveis a umidade relativa, tipo de cimento, resistência à compressão e temperatura.

\subsection{Metodologia}

A magnitude de variação dos parâmetros estudados foi selecionada a fim de que os parâmetros escolhidos representassem condições laboratoriais, procedimentos de ensaio, condições de carregamento e características dos materiais muito distintos. Os traços analisados estão apresentados na tabela 3.1.

Foram selecionadas duas classes de resistência característica à compressão, ou seja, $30 \mathrm{MPa}$ e $50 \mathrm{MPa}$. O concreto de classe $30 \mathrm{MPa}$ é comumente utilizado e a classe $50 \mathrm{MPa}$ é a maior classe de resistência característica à compressão permitida pela NBR.

Cada classe foi analisada utilizando dois tipos de cimento, CPIII40RS e o CPVARIRS. Como estes dois cimentos possuem características muito distintas, é interessante verificar a sensibilidade dos modelos variando este parâmetro. Enquanto o CPIII40RS admite substituição do clínquer de 30 a $70 \%$ de escória 
granulada de alto-forno, o CPV-ARIRS constitui um cimento de alta resistência inicial muito fino (Blaine > 3000).

Além disso, para cada condição foi feito um estudo considerando a temperatura constante em $23^{\circ} \mathrm{C}$ variando a umidade relativa em 40,60 e $80 \%$ e considerando a umidade relativa constante em $60 \%$ variando a temperatura em 15,23 e $30^{\circ} \mathrm{C}$. As condições climáticas médias avaliadas neste trabalho foram registradas no Estado de São Paulo, conforme Kataoka (2005). A variação da temperatura e umidade relativa consideradas teve a finalidade de verificar a influência destes parâmetros nestas propriedades.

Alguns parâmetros foram mantidos constantes, tais como:

- O formato cilíndrico do corpo de prova e as dimensões de $15 \times 30 \mathrm{~cm}$ prescritas tanto nos modelos das normas quanto nos modelos da literatura;

- O abatimento em $100 \mathrm{~mm}$, pois os concretos são usinados e este abatimento permite que sejam bombeados na obra;

- A idade de carregamento em 28 dias uma vez que o objetivo é comparar classes de concretos distintas;

- O tempo de cura de 28 dias, considerando que o corpo de prova é curado até a data do ensaio;

- O tipo de cura úmida.

As diversas condições totalizaram em 24 combinações distintas avaliadas para cada propriedade de fluência e retração. $\mathrm{Na}$ figura 3.1, estão apresentadas, em resumo, as condições empregadas para avaliação paramétrica:

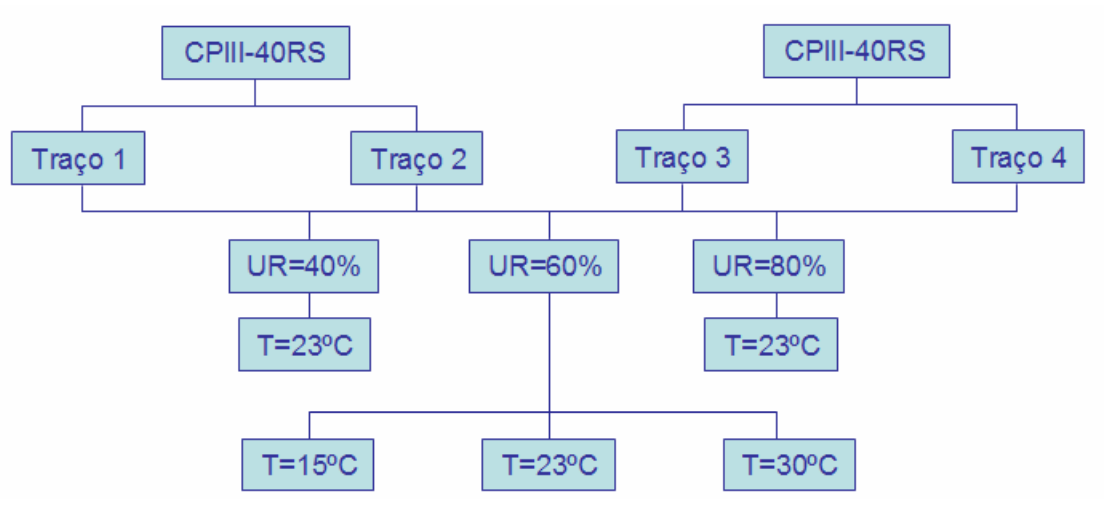

Figura 3.1 - Condições empregadas na avaliação paramétrica. 
Tabela 3.1 - Traços analisados.

\begin{tabular}{|c|c|c|c|c|}
\hline Traço & 1 & 2 & 3 & 4 \\
\hline Tipo de cimento & CPIII40RS & CPIII40RS & CPV-ARIRS & CPV-ARIRS \\
\hline Cimento $\left(\mathrm{kg} / \mathrm{m}^{3}\right)$ & 292 & 470 & 301 & 439 \\
\hline Areia de brita $\left(\mathrm{kg} / \mathrm{m}^{3}\right)$ & 416 & 349 & 409 & 299 \\
\hline Areia de quartzo $\left(\mathrm{kg} / \mathrm{m}^{3}\right)$ & 417 & 347 & 408 & 437 \\
\hline $\operatorname{Brita}\left(\mathrm{kg} / \mathrm{m}^{3}\right)$ & 1082 & 1059 & 1075 & 1025 \\
\hline Água $\left(\mathrm{kg} / \mathrm{m}^{3}\right)$ & 164 & 170 & 169 & 174 \\
\hline $\begin{array}{l}\text { Aditivo polifuncional } \\
\qquad\left(\mathrm{kg} / \mathrm{m}^{3}\right)\end{array}$ & 2,046 & 3,287 & 2,711 & 2,197 \\
\hline $\mathrm{a} / \mathrm{c}(\mathrm{kg} / \mathrm{kg})$ & 0,56 & 0,36 & 0,56 & 0,39 \\
\hline $\mathrm{m}(\mathrm{kg} / \mathrm{kg})$ & 6,55 & 3,73 & 6,29 & 4,01 \\
\hline $\mathrm{f}_{\mathrm{ck}}(\mathrm{MPa})$ & 30 & 50 & 30 & 50 \\
\hline Traço unitário (massa) & $1: 2,8: 3,7 ; 0,56$ & $1: 1,48: 2,25 ; 0,36$ & $1: 2,72: 3,57 ; 0,56$ & $1: 1,68: 2,33 ; 0,39$ \\
\hline
\end{tabular}

As avaliações percentuais são feitas aos 900 dias, considerando a fluência específica $(\mathrm{J})$ em $\times 10^{-6} / \mathrm{MPa}$ para fluência e a deformação em $\times 10^{-6}$ para retração. A partir dos resultados obtidos aos 900 dias, são consideradas mudanças significativas àquelas superiores que $5 \%$. Utilizou-se o programa MatLab 7.0. (MATrix LABoratory da MATHWORKS) para implementar os cinco modelos propostos nesta pesquisa. Este programa possui uma linguagem de programação de alto nível, cuja principal característica é a fácil manipulação e armazenamento de dados em matrizes, muito útil quando se trabalha com o método dos elementos finitos (MATHWORKS, 2009).

\subsection{Resultados e análises}

Os gráficos 3.1a, 3.1b, 3.1c, 3.1d, 3.2a, 3.2b, 3.2c e 3.2d apresentam a sensibilidade em porcentagem dos modelos de fluência e retração, considerando como referência as condições apresentadas abaixo de cada gráfico. A variação dos parâmetros está descrita na legenda de cada gráfico. 


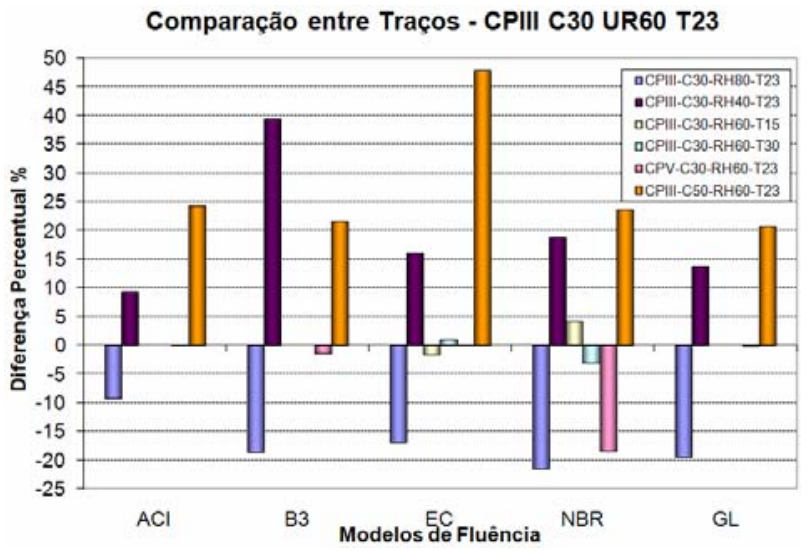

a) CPIII4ORS, 30MPa, UR $=60 \%$ e $\mathrm{T}=23^{\circ} \mathrm{C}$.

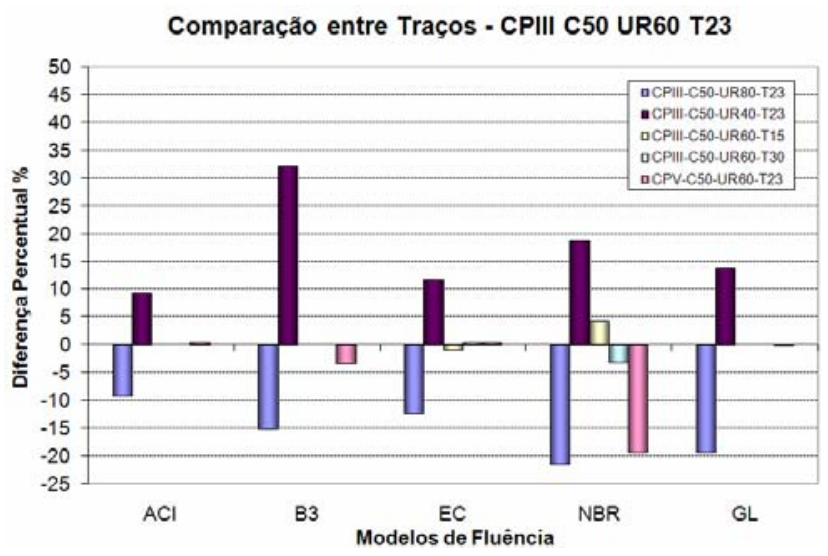

c) CPIII40RS, $50 \mathrm{MPa}$, UR $=60 \%$ e T $=23^{\circ} \mathrm{C}$.

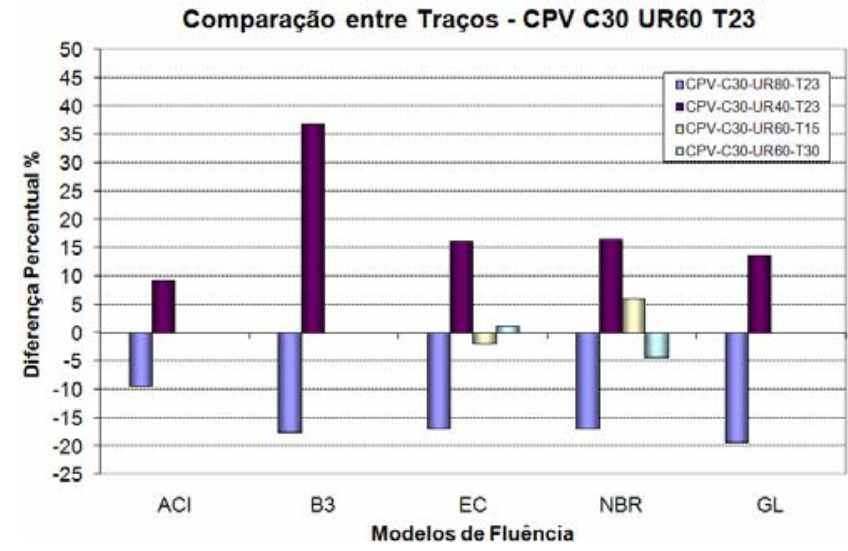

b) CPV-ARIRS, 30MPa, UR $=60 \%$ e $\mathrm{T}=23^{\circ} \mathrm{C}$.

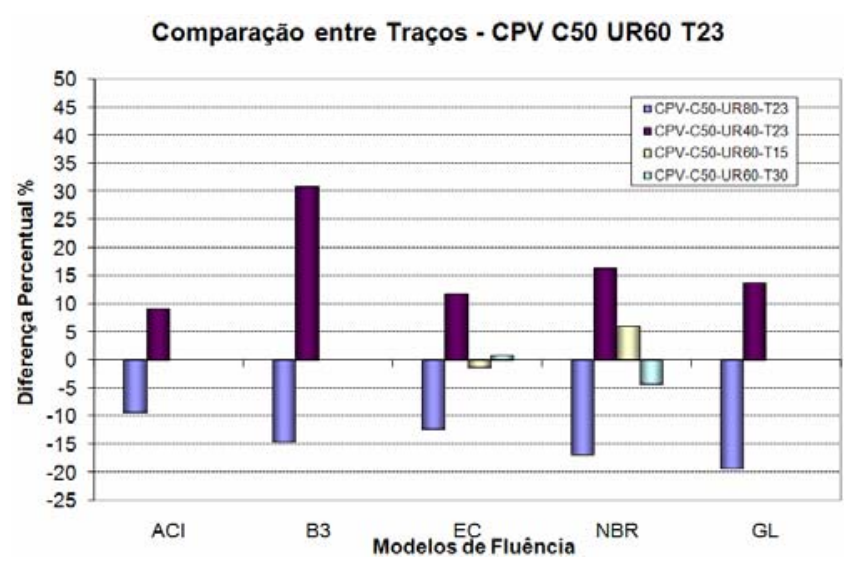

d) CPV-ARIRS, 30MPa, UR $=60 \%$ e $\mathrm{T}=23^{\circ} \mathrm{C}$.

\section{Gráfico 3.1 - Sensibilidade paramétrica dos modelos de fluência.}

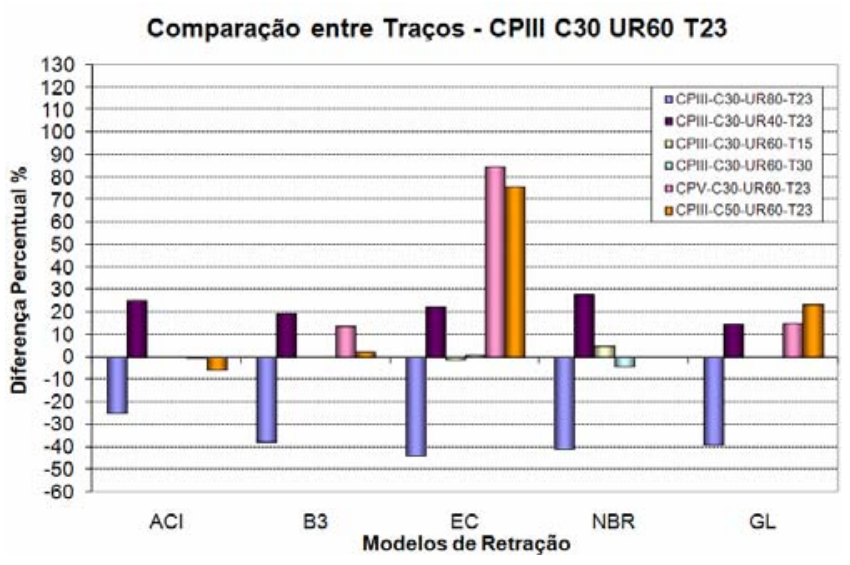

a) CPIII40RS, 30MPa, UR $=60 \%$ e T $=23^{\circ} \mathrm{C}$.

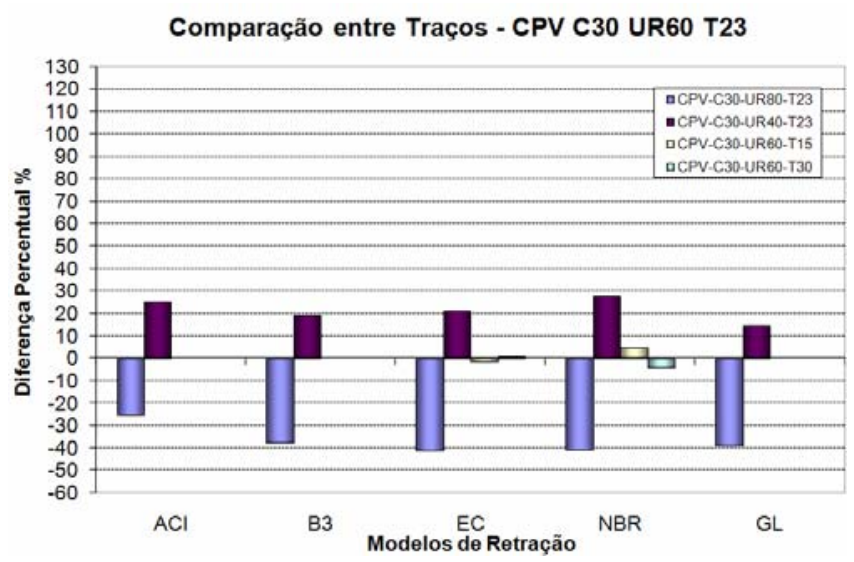

b) CPV-ARIRS, $30 \mathrm{MPa}$, UR $=60 \%$ e $\mathrm{T}=23^{\circ} \mathrm{C}$. 


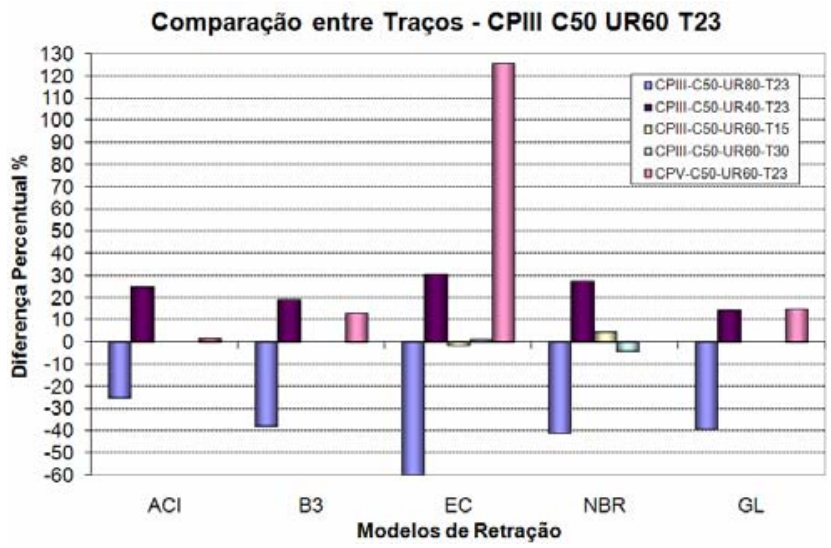

c) CPIII4ORS, 50MPa, UR $=60 \%$ e $\mathrm{T}=23^{\circ} \mathrm{C}$.

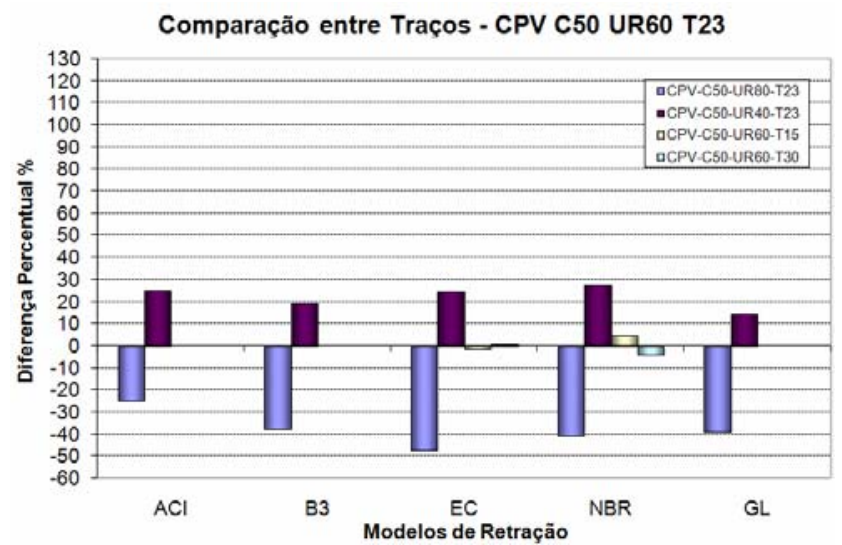

d) CPV-ARIRS, $50 \mathrm{MPa}$, UR $=60 \%$ e $\mathrm{T}=23^{\circ} \mathrm{C}$. Gráfico 3.2 - Sensibilidade paramétrica dos modelos de retração.

\subsubsection{Umidade relativa}

Em todos os modelos pode-se notar que a variação da umidade relativa altera as curvas de fluência específica ao longo de todo período analisado. De acordo com Mehta e Monteiro (2008) quando a umidade relativa é aumentada tanto à fluência quanto a retração diminuem, pois há uma redução da taxa relativa do fluxo de umidade entre o concreto e o ambiente. Howells; Lark e Barr (2005) verificaram aos 730 dias a previsão das deformações por fluência do modelo B3 teve uma diminuição de $84 \%$ com aumento da umidade relativa de $45 \%$ para $75 \%$. O mesmo pode ser visto no gráfico $3.1 \mathrm{a}$, por exemplo, para um concreto com classe $30 \mathrm{MPa}$ composto por CPIII40RS, houve um aumento da fluência específica aos 900 dias de $58 \%$ com aumento da umidade relativa de $40 \%$ para $80 \%$.

Considerando ambas as classes e tipos de cimentos analisados, para o modelo do $\mathrm{ACl}$ houve uma variação uniforme da fluência específica de $+9 \%$ e $-9 \%$ quando a umidade relativa é alterada de $60 \%$ a $40 \%$ e de $60 \%$ a $80 \%$, respectivamente. O modelo B3 apresentou maior diferença relativa ( $\approx+40 \%$ ) quando a umidade relativa foi alterada de $60 \%$ para $40 \%$ do que quando comparada com a mudança de $60 \%$ para $80 \%$ ( $\approx-18 \%$ ). Al-Manasseer e Masood (2008) também verificaram que os modelos do $\mathrm{ACl}, \mathrm{B} 3$ e $\mathrm{GL}$ apresentaram mudanças significativas na alteração da umidade relativa.

Todos os modelos de retração são influenciados pela mudança da umidade relativa. Pode-se notar que aos 900 dias o modelo do $\mathrm{ACl}$ tem uma variação 
uniforme de aproximadamente $+25 \%$ e $-25 \%$ com a mudança da umidade relativa de $60 \%$ para $40 \%$ e $60 \%$ para $80 \%$, respectivamente. Os modelos do B3, EC2, NBR e GL demonstraram uma maior variação na mudança da umidade relativa de $60 \%$ para $40 \%$, quando comparado com a mudança de $60 \%$ para $80 \%$. A maior diferença é observada no modelo do EC2 correspondendo a variações de $+60 \%$ e $30 \%$ com a mudança da umidade relativa de $60 \%$ para $40 \%$ e $60 \%$ para $80 \%$, respectivamente.

Estas diferenças distintas entre deformações quando a umidade relativa é alterada de $60-80 \%$ e de $60-40 \%$, tanto na fluência quanto na retração, pode ser explicada pelo fato de que no meio saturado, ou seja, umidade relativa a 100\%, não há nem retração por secagem nem fluência (MEHTA; MONTEIRO, 2008). Portanto, quanto mais perto do meio saturado menores são estas deformações.

\subsubsection{Tipo de cimento}

Como pode ser visto nos gráficos 3.1a e 3.1c, somente o modelo de fluência da NBR é sensível ao tipo de cimento, apresentando fluência aproximadamente $20 \%$ maior para o cimento CPIII40RS para as classes, umidades relativas e temperaturas avaliadas nesta pesquisa. Entretanto, é interessante ressaltar que para umidade relativa de $80 \%$ há um menor acréscimo da fluência em relação à alteração do tipo cimento, ou seja, de $14 \%$. Isso pode ser explicado pelo fato do grão do cimento ter se hidratado mais devido à maior presença de umidade, conseqüentemente, há menos água de gel que seria a grande responsável pelas deformações por fluência. Entretanto, o tipo de cimento tem efeito sobre a fluência através da interferência sobre a resistência do concreto logo após a aplicação de carga, Neville (1997). Por esse motivo, qualquer comparação de concretos feitos com diferentes tipos de cimento deveria levar em conta a influência do tipo de cimento sobre a resistência no momento da aplicação da carga. Portanto, todos os modelos deveriam sofrer alterações nas deformações, fato não observado.

Com relação às deformações por retração, somente os modelos do EC2, GL e B3 apresentam sensibilidade à mudança do tipo de cimento. O EC2 é o modelo mais sensível a este parâmetro aumentando em aproximadamente $85 \%$ e $125 \%$ as 
deformações por retração para o concreto de $30 \mathrm{MPa}$ e $50 \mathrm{MPa}$, respectivamente. O modelo de retração do GL aumenta aproximadamente $14 \%$ às deformações.

\subsubsection{Temperatura}

Como a temperatura é dado de entrada somente para os modelos de fluência e retração da NBR e EC2, somente ocorreram alterações nas deformações quando houve mudança da temperatura nestes modelos. Entretanto, estas alterações não foram significativas ao longo do tempo tanto para retração quanto para fluência, com exceção do modelo da NBR que apresentou alterações de deformações por fluência maiores ( $\approx 6 \%)$ para o cimento CPV-ARIRS e mudança de temperatura de $23^{\circ} \mathrm{C}$ para $15^{\circ} \mathrm{C}$, cimento CPV-ARIRS e classe $30 \mathrm{MPa}$. Para temperaturas menores $\left(15^{\circ} \mathrm{C}\right)$ o modelo da NBR apresentou deformações por fluência superiores quando comparadas com aquelas submetidas a temperaturas maiores $\left(30^{\circ} \mathrm{C}\right)$. Isso pode ser explicado pelo fato do modelo da NBR utilizar a temperatura para corrigir a idade do concreto antes do carregamento e ao longo do tempo. O modelo da NBR prescreve que não há correção da idade quando a temperatura é de $20^{\circ} \mathrm{C}$. Para temperaturas maiores do que esse valor há uma aceleração da idade do concreto enquanto que para temperaturas menores ocorre um retardo da mesma. Acelerando o crescimento da idade do concreto, também ocorre um maior crescimento da resistência ao longo do tempo, conseqüentemente as deformações por fluência e retração são menores. Enquanto que retardando este crescimento, ocorre um fenômeno oposto.

\subsubsection{Resistência à compressão}

Quando se aumenta a resistência do concreto é esperado que haja uma redução tanto na fluência quanto na retração por secagem, uma vez que o aumento da resistência induz a diminuição da relação água cimento. No estudo de Howells; Lark e Barr (2005) aumentando a resistência de 40 para $120 \mathrm{MPa}$ há redução 
muito grande da fluência e retração. Howells; Lark e Barr (2005) afirmam que alterando a resistência, outros fatores também são modificados. Na fluência, todos os modelos apresentaram muita sensibilidade à mudança de resistência à compressão de $30 \mathrm{MPa}$ para $50 \mathrm{MPa}$. A maior diferença observada foi para o modelo do EC2 ( $\approx 50 \%)$ enquanto que para os outros modelos a diferença foi de aproximadamente 25\%. Al-Manasseer e Masood (2008) verificaram grande influência da resistência à compressão nos modelos de fluência do B3 e do GL. Na retração, os únicos modelos que sofrem alterações significativas são os do EC2 e GL, apresentando diferenças de aproximadamente $67 \%$ e $24 \%$, respectivamente. 


\section{CAPÍTULO 4 \\ PROGRAMA EXPERIMENTAL}

O programa experimental tem como objetivo caracterizar em laboratório a deformabilidade ao longo do tempo por fluência e retração em corpos de prova de concreto, assim como suas propriedades mecânicas (resistência à compressão, módulo de elasticidade e resistência à tração por compressão diametral). Além disso, com o objetivo de realizar uma aplicação prática da caracterização das propriedades de fluência e retração do concreto, pretende-se avaliar a influência da taxa de armadura na redistribuição de tensões do concreto para a armadura em protótipos de pilares de concreto armado. O programa experimental foi desenvolvido no Laboratório de Estruturas e Materiais estruturais - LEM e no Laboratório da Engemix.

Neste item é primeiramente apresentada a definição do programa experimental, em seguida os materiais e equipamentos utilizados e, por último, descritas as metodologias empregadas para realização dos ensaios de fluência e retração em corpos de prova e em protótipos de pilares.

Na definição do programa experimental são escolhidos os traços utilizados e é feito o planejamento dos ensaios. Além da descrição dos materiais e equipamentos são feitas aferições dos mesmos, que são de extrema importância para o desenvolvimento experimental. Todos os procedimentos experimentais utilizados para os ensaios de caracterização da fluência e retração em corpos de prova e para os ensaios dos protótipos de pilares estão descritos detalhadamente nas metodologias empregadas.

\subsection{Definição do programa experimental}

No programa experimental foi utilizado um tipo de cimento (CPIIE40) considerando quatro relações água cimento de 0,78 (Traço I), 0,59 (Traço II), 0,41 (Traço III) e 
0,37 (Traço IV) para concreto convencional. Estes traços selecionados foram fornecidos pela Engemix e são comumente usados em obras, uma vez que um dos objetivos da pesquisa é avaliar a deformabilidade de concretos comerciais. As características do traço estudado estão apresentadas na tabela 4.1.

Tabela 4.1 - Traços de concreto convencional estudados para CPIIE40.

\begin{tabular}{ccccc}
\hline \multirow{2}{*}{ Componentes } & \multicolumn{4}{c}{ Traço (tipo de cimento) } \\
\cline { 2 - 5 } & Traço I & Traço II & Traço III & Traço IV \\
\hline Cimento $\left(\mathrm{kg} / \mathrm{m}^{3}\right)$ & 225 & 280 & 424 & 470 \\
Areia de brita $\left(\mathrm{kg} / \mathrm{m}^{3}\right)$ & 487 & 460 & 390 & 350 \\
Areia de quartzo $\left(\mathrm{kg} / \mathrm{m}^{3}\right)$ & 394 & 372 & 315 & 346 \\
Brita 0 $\left(\mathrm{kg} / \mathrm{m}^{3}\right)$ & 157 & 157 & --- & --- \\
Brita $1\left(\mathrm{~kg} / \mathrm{m}^{3}\right)$ & 911 & 911 & 1073 & 1060 \\
Água $\left(\mathrm{kg} / \mathrm{m}^{3}\right)$ & 225 & 164 & 174 & 172 \\
Aditivo polifuncional & 1,797 & 1,957 & 3,607 & 3,995 \\
$\left(\mathrm{~kg} / \mathrm{m}^{3}\right)$ & 0,78 & 0,56 & 0,41 & 0,37 \\
a/c $(\mathrm{kg} / \mathrm{kg})$ & 20 & 30 & 40 & 50 \\
$\mathrm{f}_{\mathrm{ck}}(\mathrm{MPa})$ & $1: 3,92: 4,75 ; 0,78$ & $1: 2,97: 3,81 ; 0,59$ & $1: 1,66: 2,53 ; 0,41$ & $1: 1.48: 2.26 ; 0,37$ \\
\hline Traço unitário $(\mathrm{massa})$ & & & &
\end{tabular}

O programa experimental foi dividido em duas etapas (figura 4.1). Na primeira etapa foram monitoradas as deformações por fluência e retração dos traços da tabela 4.1. Na segunda etapa, a fluência e retração foram caracterizadas para protótipos de pilares com duas taxas de armadura, detalhados no item 4.6. Nesta segunda etapa, também foram moldados corpos de prova cilíndricos do Traço II com a finalidade de caracterizar a propriedade de fluência e retração por secagem e verificar a validade da caracterização destas propriedades em corpos de prova cilíndricos para prever deformações em protótipos de pilares prismáticos.

Para caracterização das propriedades de fluência e retração foram previstos diversos ensaios, tais como: ensaio de fluência por secagem e básica e retração por secagem e autógena (corpos de prova complementares) em corpos de prova cilíndricos, assim como ensaios de retração por secagem em corpos de prova prismáticos. A caracterização da fluência foi feita para os Traços I, II e III, enquanto que a retração foi caracterizada para os Traços I, III e IV. Os protótipos de pilares foram moldados utilizando o Traço II. 


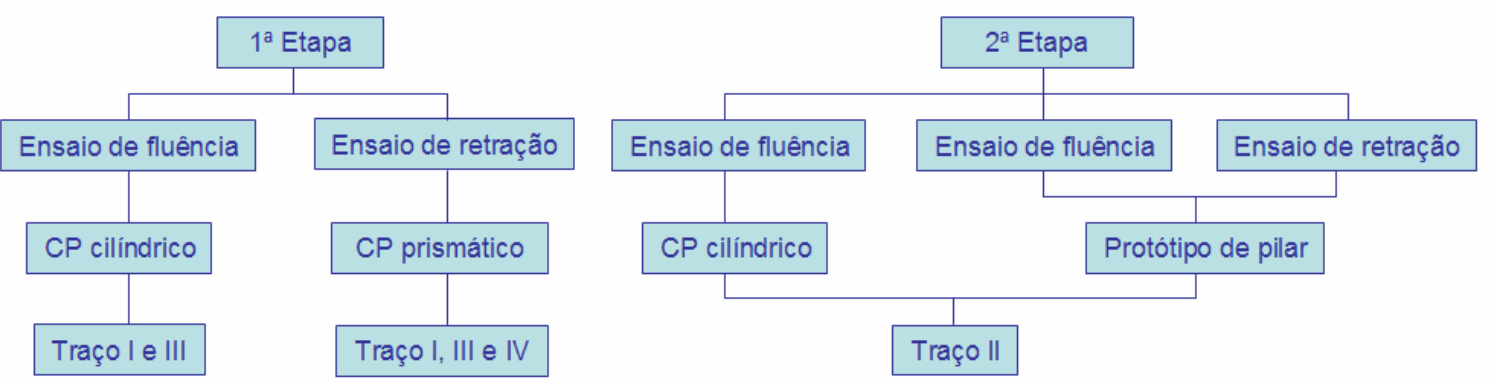

Figura 4.1 - Etapas do programa experimental.

O ensaio de fluência foi feito de acordo com a NBR8224 (1983). O carregamento dos ensaios de fluência foi feito aos 7 dias a 40\%, 30\% e 20\% da resistência média à compressão do concreto. Os ensaios foram conduzidos em uma câmara climatizada com temperatura e umidade relativa controlada em $23 \pm 1^{\circ} \mathrm{C}$ e $60 \pm 4 \%$, respectivamente. A monitoração da fluência foi realizada desde a data de carregamento ( 7 dias) até 91 dias de idade do concreto.

O ensaio de retração foi realizado baseado nas normas ASTMC490 (1997) e NBRNM131 (1998). Tais normas especificam que as medições sejam feitas a partir do primeiro dia de desmoldagem. Nesta pesquisa, as leituras foram feitas até 154 dias.

Também foram moldados corpos de prova cilíndricos para caracterização da resistência média à compressão, resistência à tração por compressão diametral e módulo de elasticidade para as idades de 7, 28, 63 e 91 dias. As moldagens foram feitas de acordo com a NBR5738 (2003). Os ensaios de resistência à compressão, resistência à tração por compressão diametral e módulo de elasticidade foram realizados de acordo com as normas NBR5739 (1994), NBR7222 (1994) e NBR8522 (2003), respectivamente.

Para o concreto fresco foram determinados o teor de ar incorporado de acordo com a NBRNM47 (2002) e a consistência do concreto conforme a NBRNM67 (1998). O planejamento está definido conforme as tabelas 4.2 e 4.3 .

Tabela 4.2 - Planejamento dos ensaios (tração, compressão e módulo).

\begin{tabular}{ccccccc}
\hline \multirow{2}{*}{ CPs $^{*}$} & \multirow{2}{*}{ Propriedade } & \multicolumn{5}{c}{ Idade (dias) } \\
\cline { 3 - 7 } & 7 & 28 & 63 & 91 & Total \\
\hline \multirow{3}{*}{$10 \times 20 \mathrm{~cm}$} & Tração & 3 & 3 & 3 & 3 & 12 \\
& Compressão & 3 & 3 & 3 & 3 & 12 \\
& Módulo & 3 & 3 & 3 & 3 & 12 \\
\hline
\end{tabular}

${ }^{*} \mathrm{CPs}$ - corpos de prova. 
Tabela 4.3 - Planejamento dos ensaios (fluência e retração).

\begin{tabular}{ccc}
\hline $\mathrm{CPs}^{*}$ & $\begin{array}{c}\text { Propriedades } \\
\text { Mecânicas }\end{array}$ & Número de $\mathrm{CPs}^{*}$ \\
& Retração Autógena & 1 \\
\multirow{2}{*}{$15 \times 30 \mathrm{~cm}$} & Fluência Básica & 2 \\
& Retração Por Secagem & 1 \\
& Fluência Por Secagem & 2 \\
\hline \multirow{2}{*}{$10 \times 10 \times 30 \mathrm{~cm}$} & 6 \\
\hline & Retal & 5 \\
\hline${ }^{*} \mathrm{CPs}-$ corpos de prova. & 5
\end{tabular}

\subsection{Materiais empregados nos traços}

Neste item está apresentada a caracterização tanto dos materiais utilizados na primeira quanto os utilizados na segunda etapa de ensaio.

Portanto, neste item, são apresentadas as caracterizações do cimento CPIIE40 e do agregado miúdo, de dois tipos de agregados graúdos (brita 1 e brita 0) e do aditivo polifuncional empregados.

\subsubsection{Cimento}

O cimento CPIIE40 admite grande substituição do clínquer por escória de alto-forno em até $36 \%$. A caracterização físico-química do cimento está apresentada na tabela 4.4 .

\subsubsection{Agregado miúdo}

O agregado miúdo utilizado é uma mistura de dois tipos de areias: areia natural e areia de brita de calcário com dimensão máxima de 1,2 e 2,4 mm, 
respectivamente. A areia de brita é um resíduo do agregado graúdo de origem calcária. A caracterização física dos agregados miúdos está apresentada na tabela 4.5 .

Tabela 4.4 - Propriedades físico-químicas do cimento.

\begin{tabular}{lc}
\hline \multicolumn{1}{c}{ Constituinte/propriedades } & Cimento \\
\hline $\mathrm{MgO}(\%)$ & 5,22 \\
$\mathrm{SO}_{3}(\%)$ & 2,72 \\
$\mathrm{CO}_{2}(\%)$ & 2,64 \\
Resíduo (\%) & 1,03 \\
Finura (cm $\left.{ }^{2} / \mathrm{g}\right)$ & 4113 \\
Tempo inicial de pega (h:min) & $2: 50$ \\
Tempo final de pega (h:min) & $3: 50$ \\
Resistência à compressão de cilindros de \\
10x20cm (MPa) \\
3 dias \\
7 dias \\
28 dias & 25,8 \\
\end{tabular}

Tabela 4.5 - Caracterização física dos agregados miúdos (areia natural e areia de brita). Areia natural Areia de Brita

\begin{tabular}{|c|c|c|c|c|c|}
\hline \multirow{2}{*}{$\begin{array}{c}\text { Peneiras ABNT } \\
\text { NBRNM248,2003 }(\mathrm{mm})\end{array}$} & \multicolumn{2}{|c|}{ Porcentagens Retidas } & \multirow{2}{*}{$\begin{array}{c}\text { Peneiras ABNT } \\
\text { NBRNM248,2003 }(\mathrm{mm})\end{array}$} & \multicolumn{2}{|c|}{ Porcentagens Retidas } \\
\hline & Indiv. & Acum. & & Indiv. & Acum. \\
\hline$\# 2,4$ & 0 & 0 & $\# 2,4$ & 9 & 10 \\
\hline$\# 1,2$ & 0,3 & 0 & $\# 1,2$ & 26 & 36 \\
\hline$\# 0,6$ & 5,6 & 6 & $\# 0,6$ & 22 & 58 \\
\hline$\# 0,3$ & 28,0 & 34 & $\# 0,3$ & 17 & 75 \\
\hline$\# 0,15$ & 51,1 & 85 & $\# 0,15$ & 16 & 91 \\
\hline Resíduo & 14,9 & & Resíduo & 9 & 100 \\
\hline Total & 100,0 & 100 & Totais & 100 & 10 \\
\hline \multicolumn{2}{|c|}{ Material fino passante \#75 } & \multicolumn{4}{|c|}{ Material fino passante \#75 } \\
\hline \multicolumn{2}{|c|}{ NBRNM46,2003 (\%) } & 2 & \multicolumn{2}{|c|}{ NBRNM46,2003 (\%) } & 3,3 \\
\hline \multicolumn{6}{|c|}{ Dimensão máxima característica } \\
\hline \multicolumn{2}{|l|}{$(\mathrm{mm})$} & 1,2 & \multicolumn{2}{|c|}{ Dimensão máxima característica (mm) } & 2,4 \\
\hline \multicolumn{2}{|c|}{ Módulo de finura } & 1,25 & \multicolumn{2}{|c|}{ Módulo de finura } & 2,70 \\
\hline \multicolumn{2}{|c|}{ Massa específica } & & \multicolumn{2}{|c|}{ Massa específica } & \\
\hline \multicolumn{2}{|c|}{ NBRNM52,2003 $\left(\mathrm{g} / \mathrm{cm}^{3}\right)$} & 2,64 & \multicolumn{2}{|c|}{ NBRNM52,2003 $\left(\mathrm{g} / \mathrm{cm}^{3}\right)$} & 2,68 \\
\hline \multicolumn{2}{|l|}{ Graduação } & $\begin{array}{l}\text { Muito } \\
\text { Fina }\end{array}$ & \multicolumn{2}{|l|}{ Graduação } & Média \\
\hline
\end{tabular}




\subsubsection{Agregado graúdo}

O agregado graúdo utilizado é de origem calcária com dimensão máxima de 19 mm. A caracterização física do agregado graúdo está apresentada na tabela 4.6.

Tabela 4.6 - Caracterização física dos agregados graúdos (Brita 0 e Brita 1).

\begin{tabular}{|c|c|c|c|c|c|}
\hline \multicolumn{3}{|c|}{ Agregado graúdo (Brita 1) } & \multicolumn{3}{|c|}{ Agregado graúdo (Brita 0) } \\
\hline \multirow{2}{*}{$\begin{array}{c}\text { Peneiras ABNT } \\
\text { NBRNM248,2003 (mm) }\end{array}$} & \multicolumn{2}{|c|}{$\begin{array}{l}\text { Porcentagens } \\
\text { Retidas }\end{array}$} & \multirow{2}{*}{$\begin{array}{c}\text { Peneiras ABNT } \\
\text { NBRNM248,2003 }(\mathrm{mm})\end{array}$} & \multicolumn{2}{|c|}{$\begin{array}{l}\text { Porcentagens } \\
\text { Retidas }\end{array}$} \\
\hline & Indiv. & Acum. & & Indiv. & Acum. \\
\hline \#19 & 1,9 & 2 & \#19 & 0 & 0 \\
\hline$\# 12,7$ & 44,8 & 45 & $\# 12,7$ & 0 & 0 \\
\hline$\# 9,5$ & 38,2 & 85 & $\# 9,5$ & 3 & 3 \\
\hline$\# 6,3$ & 13,2 & 98 & $\# 6,3$ & 47 & 51 \\
\hline$\# 4,8$ & 0,6 & 99 & $\# 4,8$ & 32 & 83 \\
\hline$\# 2,4$ & 0,0 & 99 & $\# 2,4$ & 13 & 95 \\
\hline$\# 1,2$ & 0,0 & 99 & $\# 1,2$ & 3 & 98 \\
\hline$\# 0,6$ & 0,0 & 99 & $\# 0,6$ & 0 & 99 \\
\hline$\# 0,3$ & 0,0 & 99 & $\# 0,3$ & 1 & 99 \\
\hline$\# 0,15$ & 0,0 & 99 & $\# 0,15$ & 0 & 100 \\
\hline Resíduo & 1,3 & 100 & Resíduo & 0 & 100 \\
\hline Total & 100,0 & & Total & 100 & 577 \\
\hline \multicolumn{2}{|c|}{ Dimensão máxima característica } & \multicolumn{4}{|c|}{ Dimensão máxima característica } \\
\hline \multicolumn{2}{|l|}{$(\mathrm{mm})$} & 19 & \multicolumn{2}{|l|}{$(\mathrm{mm})$} & 9,5 \\
\hline \multicolumn{2}{|c|}{ Massa específica $\left(\mathrm{g} / \mathrm{cm}^{3}\right)$} & 2,7 & \multicolumn{2}{|c|}{ Massa específica $\left(\mathrm{g} / \mathrm{cm}^{3}\right)$} & 2,76 \\
\hline \multicolumn{2}{|l|}{ Graduação } & Brita 1 & \multicolumn{2}{|l|}{ Graduação } & Brita 0 \\
\hline
\end{tabular}

\subsubsection{Aditivo polifuncional}

Um aditivo polifuncional foi utilizado a fim de garantir que a trabalhabilidade desejada de $100 \mathrm{~mm}$. Este aditivo possui densidade de $1,2 \mathrm{~g} / \mathrm{cm}^{3}$. 


\subsection{Equipamentos e materiais dos ensaios de fluência e retração}

Neste item estão descritos os equipamentos e materiais utilizados para o ensaio de fluência e de retração, assim como a aferição dos equipamentos, com a finalidade de garantir o sucesso dos ensaios. Os equipamentos e materiais que exigem aferição são: câmara climatizada utilizada para os ensaios de fluência e retração, os equipamentos de aplicação de carga para verificação da manutenção da carga e as pontes de Wheatstone usadas para medições das deformações por fluência por meio de um aquisitor de dados.

\subsubsection{Bastidores de fluência e pórticos de retração}

Para os ensaios de fluência, foram utilizados dez bastidores de aço: cinco com capacidade de $65 \mathrm{tf}$ e cinco com capacidade de $105 \mathrm{tf}$ (figura 4.2). Considerando as condições de ensaio adotadas, ou seja, que o corpo de prova possui diâmetro de $15 \mathrm{~cm}$ e são carregados em até $40 \%$ da resistência da data do ensaio, pode-se realizar ensaios de fluência em concretos com resistência de até $90 \mathrm{MPa}$ nos bastidores de $65 \mathrm{tf}$ e de até $152 \mathrm{MPa}$ nos bastidores de 105tf.

Chapa para bastidores de 105tf

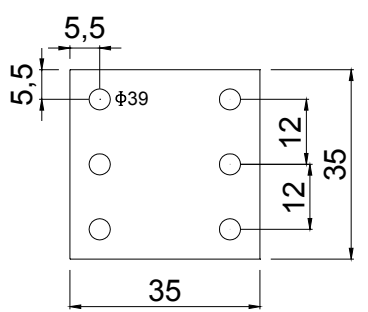

Chapa para bastidores de $65 \mathrm{tf}$

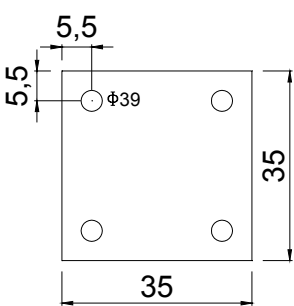

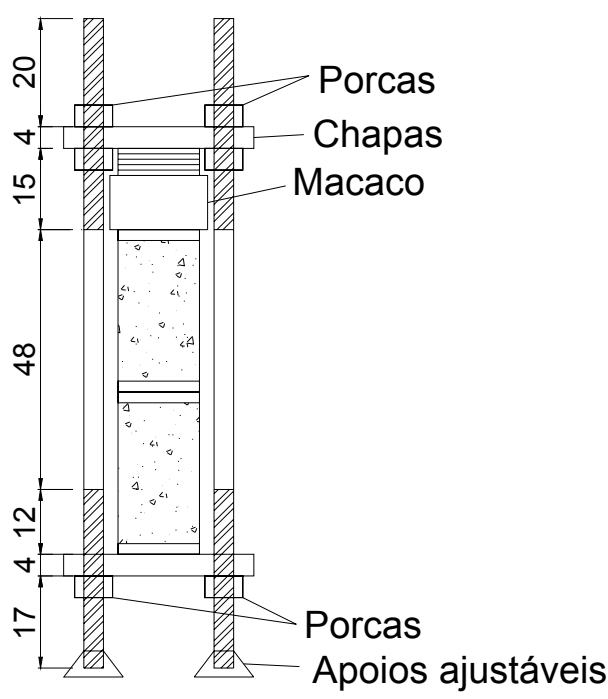

Apoios ajustáveis

Figura 4.2 - Bastidor de fluência. 
Para os ensaios de retração foi utilizado um pórtico metálico para realização das leituras de deformação. O pórtico dispõe de um relógio comparador digital com precisão de 0,001mm, fixado na barra superior do pórtico (figura 4.3).

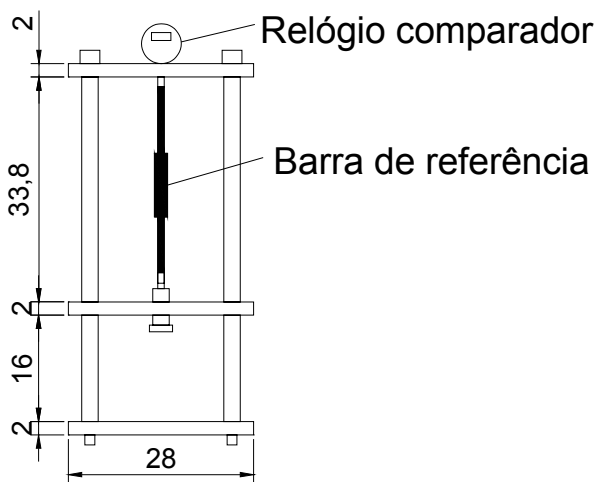

Figura 4.3 - Pórtico de retração (pórtico e barra de referência).

Para zerar o relógio comparador foi utilizada uma barra de referência. A barra foi posicionada sempre no mesmo sentido no procedimento de aferição. Este procedimento deve ser aplicado a cada série de medições realizada.

\subsubsection{Formas de fluência e retração}

As formas utilizadas nos ensaios de fluência são cilíndricas com dimensões $15 \times 30 \mathrm{~cm}$. Estas formas têm geometria especial; são bipartidas para facilitar a desmoldagem do corpo de prova e possuem na base inferior um orifício que permite a passagem do fio do sensor (figura 4.4). Além disso, estas formas foram projetadas com a finalidade de permitir o posicionamento de dois discos (inferior e superior) utilizados para dar planicidade às extremidades dos corpos de prova. $O$ disco inferior dispõe de uma ranhura para passagem do fio do sensor, assim como de um grampo que possibilita a fixação disco ao concreto. O disco superior é maciço para garantir tanto a planicidade da base do corpo de prova quanto à uniformidade da ação da carga aplicada. (figura 4.5). 

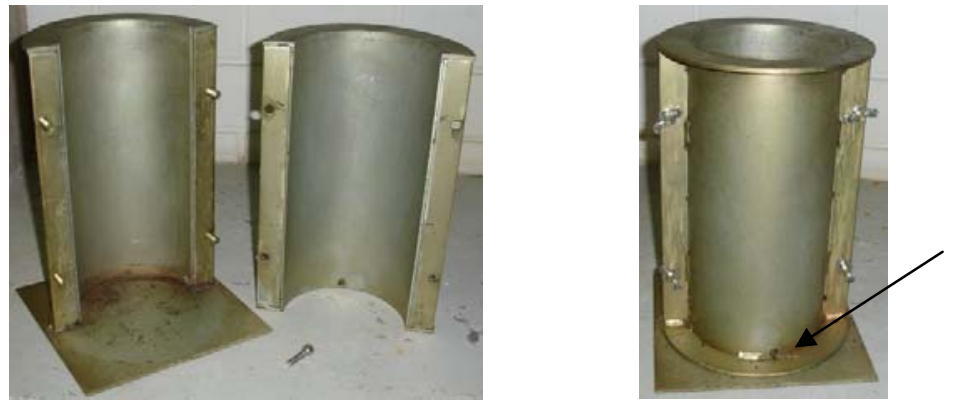

Orifício

Figura 4.4 - Forma de fluência.

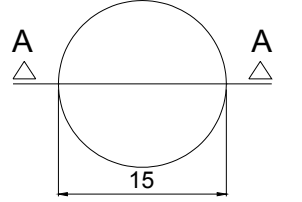

Corte A-A

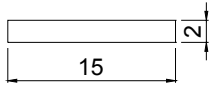

Disco inferior
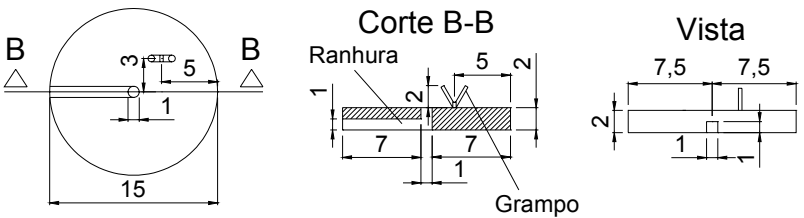

Figura 4.5 - Discos superior e inferior.

As formas utilizadas nos ensaios de retração autógena e de retração por secagem são prismáticas com dimensões $10 \times 10 \times 30 \mathrm{~cm}$, as quais ainda não são padronizadas no Brasil. Portanto, foram confeccionadas formas de policloreto de vinila (PP) com espessura de $20 \mathrm{~mm}$, baseadas na ASTMC490 (1997), conforme a figura 4.6. Seu fechamento é feito por meio do auxílio de parafusos, conforme mostrado figura 4.6a. Além disso, possuem em suas laterais menores uma rosca para posicionamento dos pinos de medida utilizados para realizar as leituras das deformações (figura 4.6b).

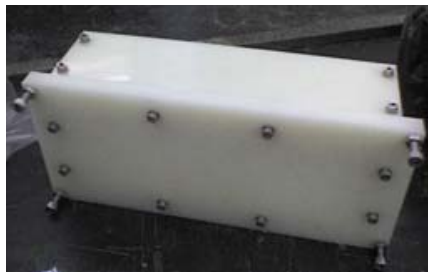

a) Vista inferior

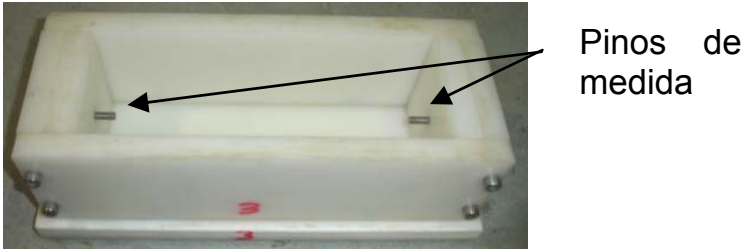

b) Vista superior

Figura 4.6 - Forma de retração. 


\subsubsection{Materiais auxiliares}

Além dos materiais supra descritos, na tabela 4.7 estão citados alguns materiais auxiliares fundamentais para realização dos ensaios de fluência e retração, assim como para monitoração das deformações.

Tabela 4.7 - Materiais auxiliares.

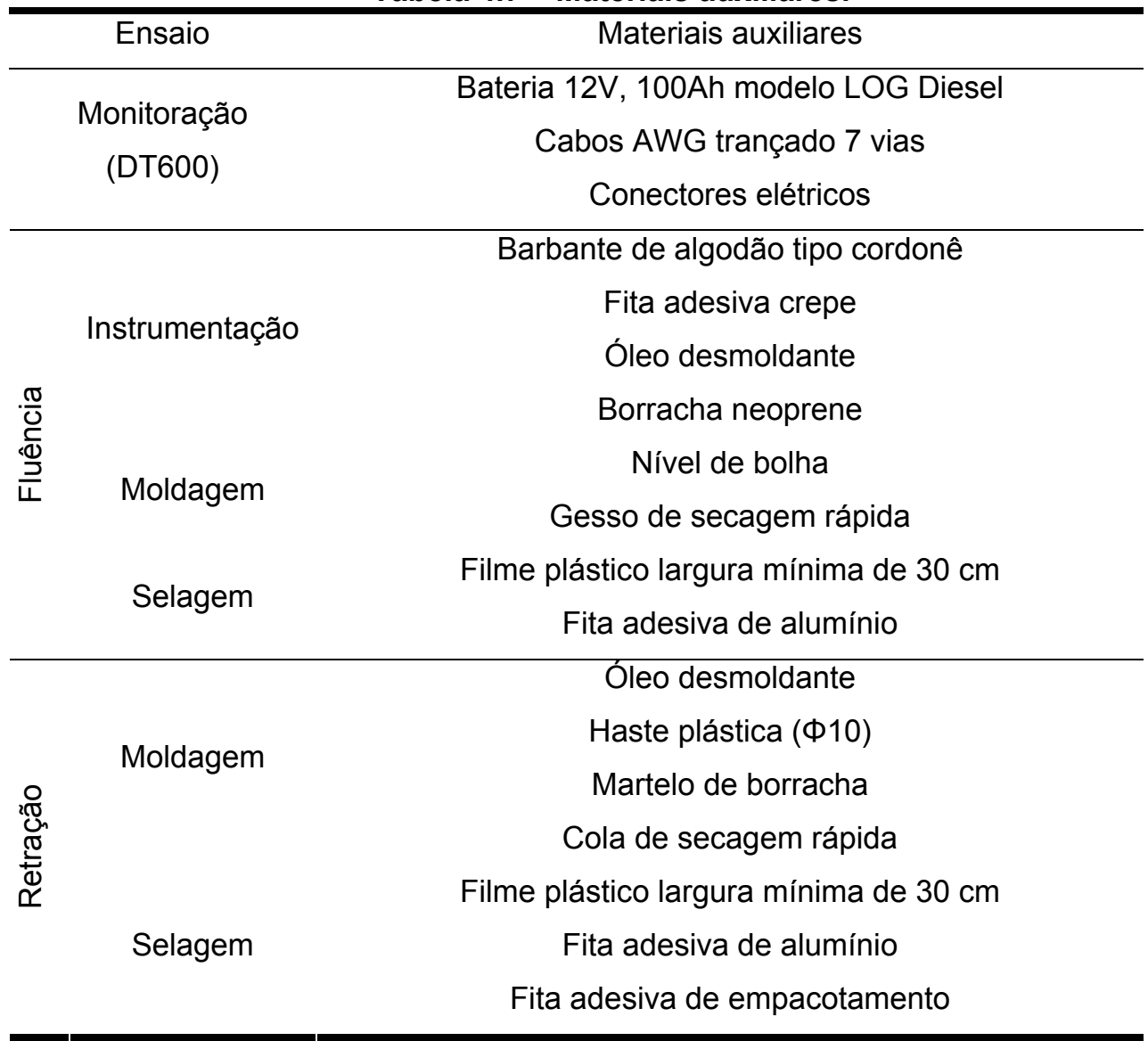

\subsubsection{Sensores}

Nesta pesquisa são utilizados sensores elétricos de resistência de imersão encapsulados (concreto) e de colagem (armadura), sensor capacitivo de umidade com base polimérica e sensor de temperatura PT100.

Os sensores elétricos de resistência são de $120 \Omega \pm 1 \%, 1 / 4$ de ponte e gage factor (constante do sensor) 2. O sensor de deformação de imersão possui dimensões de $120 \times 15 \times 5 \mathrm{~mm}$ e compensa a temperatura numa faixa de 0 a $50^{\circ} \mathrm{C}$, mas sua 
utilização está limitada a uma faixa de -10 a $70^{\circ} \mathrm{C}$ (figura 4.7 ). O sensor de deformação de colagem possui dimensões de $16 \times 5,2 \mathrm{~mm}$ e compensa a temperatura numa faixa de 10 a $100^{\circ} \mathrm{C}$, mas sua utilização está limitada a uma faixa de -196 a $150^{\circ} \mathrm{C}$ (figura 4.8). A aferição dos sensores de deformação está apresentada no Anexo A.

Juntamente com os sensores elétricos de colagem foram instrumentados terminais (figura 4.9). Os terminais têm a função de facilitar a ligação dos fios do extensômetro com os fios do cabo e proteger contra possíveis danos mecânicos.

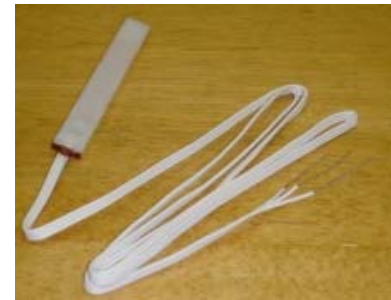

Figura 4.7 - Sensor de deformação de imersão.

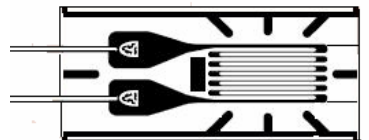

Figura 4.8 - Sensor de deformação de colagem.

\section{ॠ10100}

Figura 4.9 - Terminais.

O sensor de temperatura é do tipo termoresistência PT100, ligação simples a 3 fios. É isolado com PVC e tem precisão de $0,1^{\circ} \mathrm{C}$ atuando até a temperatura de $90^{\circ} \mathrm{C}$

O sensor de umidade tem precisão de $1 \%$ e opera em uma faixa de temperatura de 45 a $98 \%$.

\subsubsection{DataTaker e Detransfer}

Foram utilizados para a aquisição dos dados o aparelho DataTaker, modelo DT600 (figura 4.10) e DT800 (figura 4.11), controlado pelo programa DeTransfer. O DT600 e o DT800 possibilitam a entrada de sensores em 10 e 12 canais analógicos, respectivamente, dependendo do tipo de sensor. Se necessário, é possível anexar ao DT600 um módulo de expansão também com 10 canais analógicos controlado pelo módulo principal (figura 4.10). O DT600 e o DT800 possuem memória interna que possibilita o armazenamento de até 166.530 de dados (DT600 + módulo de 
expansão) e 120.000 dados, respectivamente. Esta memória permite que o computador esteja conectado apenas para enviar comandos e baixar os dados via comunicação RS232. A fonte de alimentação dos equipamentos pode ser feita tanto com fonte contínua (11 a $24 \mathrm{Vdc}$ ) como com fonte alternada (9 a $18 \mathrm{Vac}$ ). Nesta pesquisa, foi adotada como fonte de alimentação fonte contínua para evitar ruídos nos sinais e possibilitar independência do ensaio.

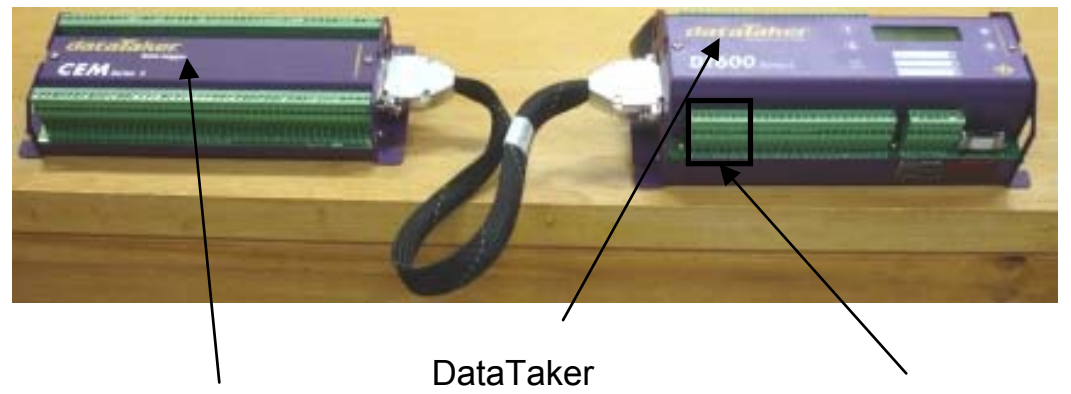

Módulo de expansão

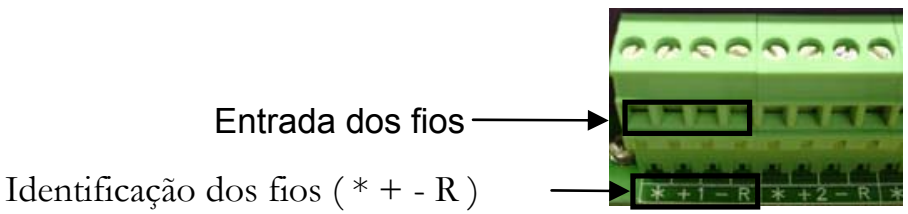

Figura 4.10 - Módulo de expansão e DataTaker DT600.

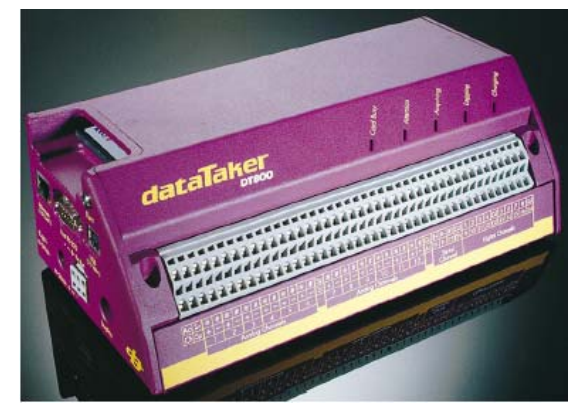

Figura 4.11 - DataTaker DT800 (Fonte: Manual técnico).

O programa de comunicação utilizado é o DeTransfer. A tela principal deste programa possui uma ou mais subjanelas de envio de comandos e recebimento de dados (figura 4.12). A subjanela de envio de comandos é utilizada para criar, editar e salvar programas do DT600 e DT800. A subjanela de recebimento de dados fornece informações em tempo real dos dados medidos, comandos enviados, testes realizados e informações das condições do equipamento. O DeTransfer utiliza linhas de comandos para o controle da taxa de aquisição, do 
armazenamento dos dados na memória e parâmetros internos do equipamento e da configuração de alarmes. As configurações de programação utilizadas para os sensores no programa estão apresentadas no Anexo B.

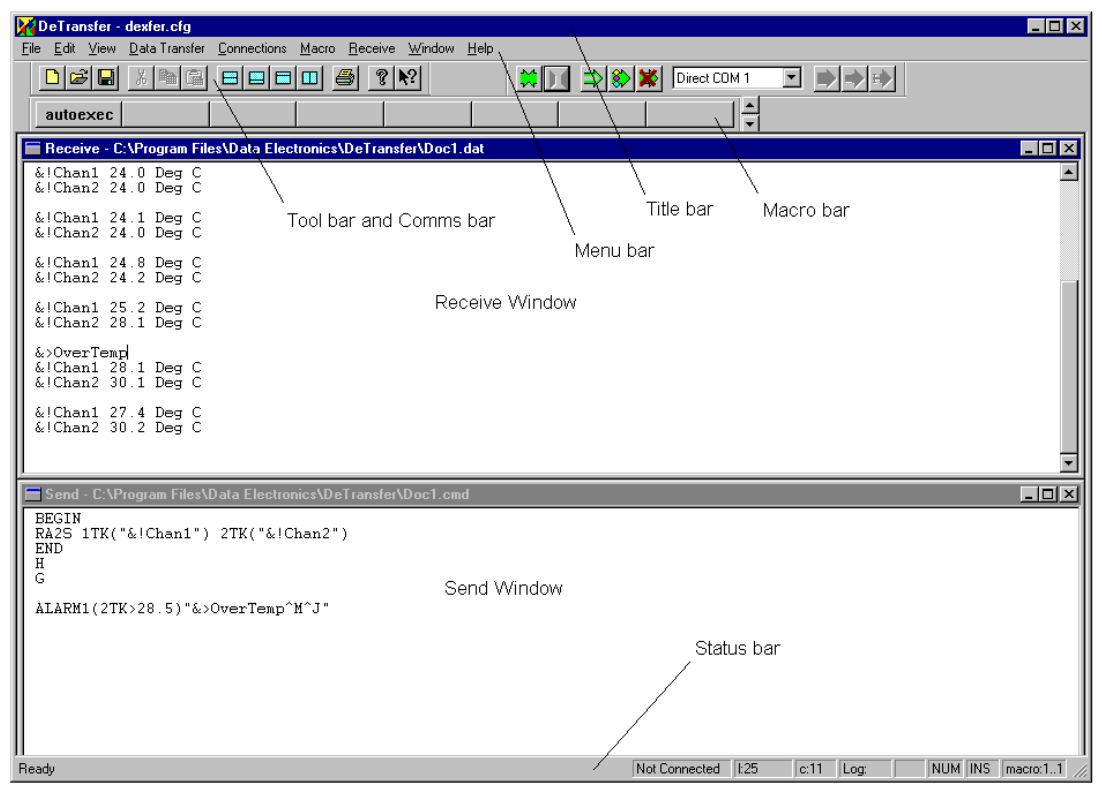

Figura 4.12 - Janela do DeTransfer (Fonte: Manual Técnico).

\subsubsection{Câmara climatizada para ensaios de fluência e retração}

A câmara climatizada possui um controlador que permite a programação da temperatura e umidade relativa, assim como as faixas de variação permitidas. Os sinais deste controlador são enviados para o sistema de aquecimento, resfriamento ou circulação do ar (figuras 4.13 e 4.14). Além disso, a câmara dispõe de uma placa de retransmissão de sinais dos sensores de temperatura e umidade relativa localizados no teto da câmara (figura 4.15).

As especificações da câmara estão descritas na tabela 4.8:

Tabela 4.8 - Especificações da câmara climatizada de fluência.

\begin{tabular}{ccccc}
\hline Sensor & \multicolumn{2}{c}{ Limites } & Incerteza & Diferença permitida \\
\hline \multirow{2}{*}{ Temperatura $\left({ }^{\circ} \mathrm{C}\right)$} & Inferior & 10 & 0,4 & \pm 1 \\
& Superior & 55 & 0,1 & \pm 1 \\
\cline { 2 - 5 } & Inferior & 45 & 1,2 & \pm 3 \\
Umidade $(\%)$ & Superior & 98 & 1,2 & \pm 3 \\
\hline
\end{tabular}




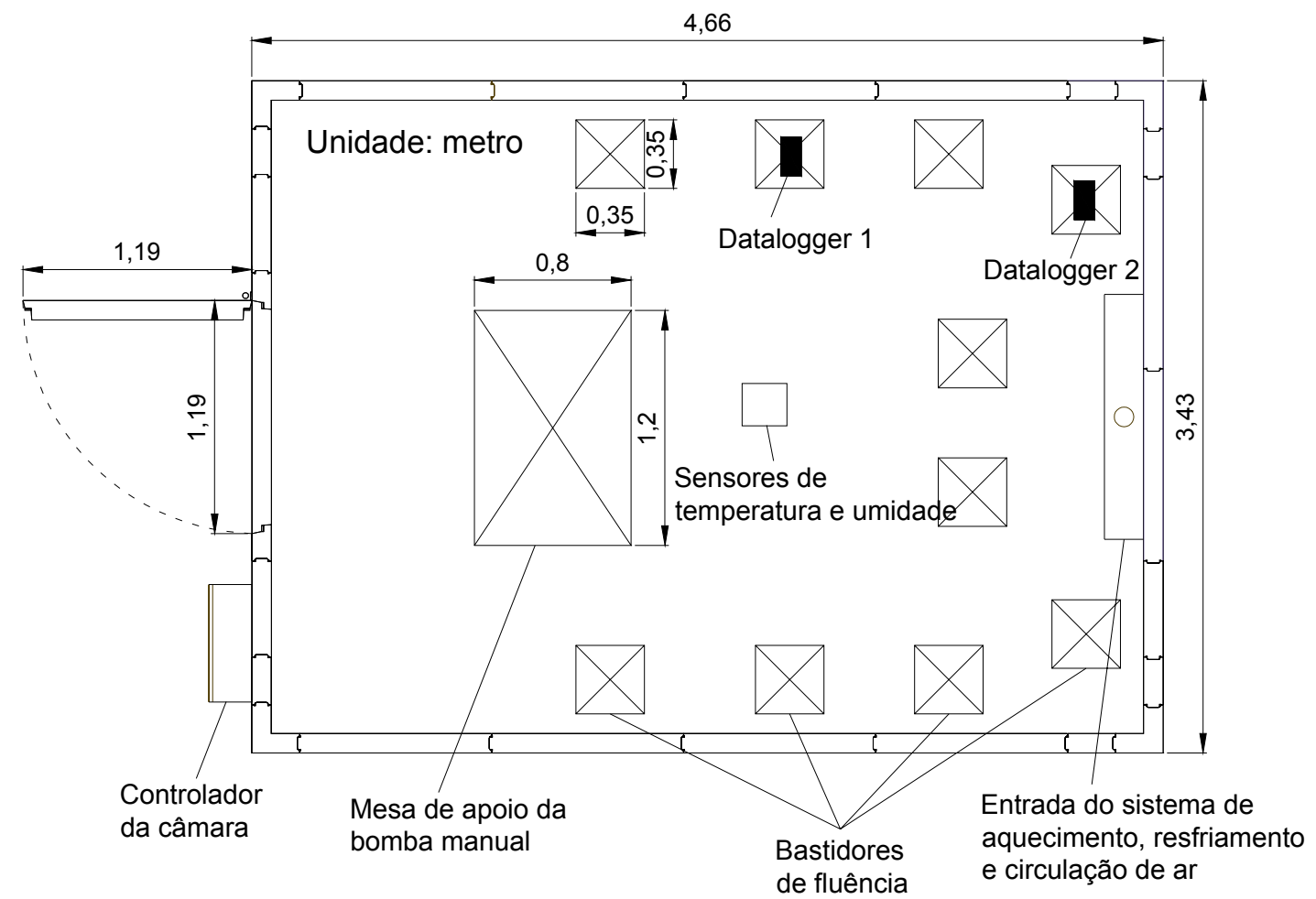

Figura 4.13 - Câmara climatizada.

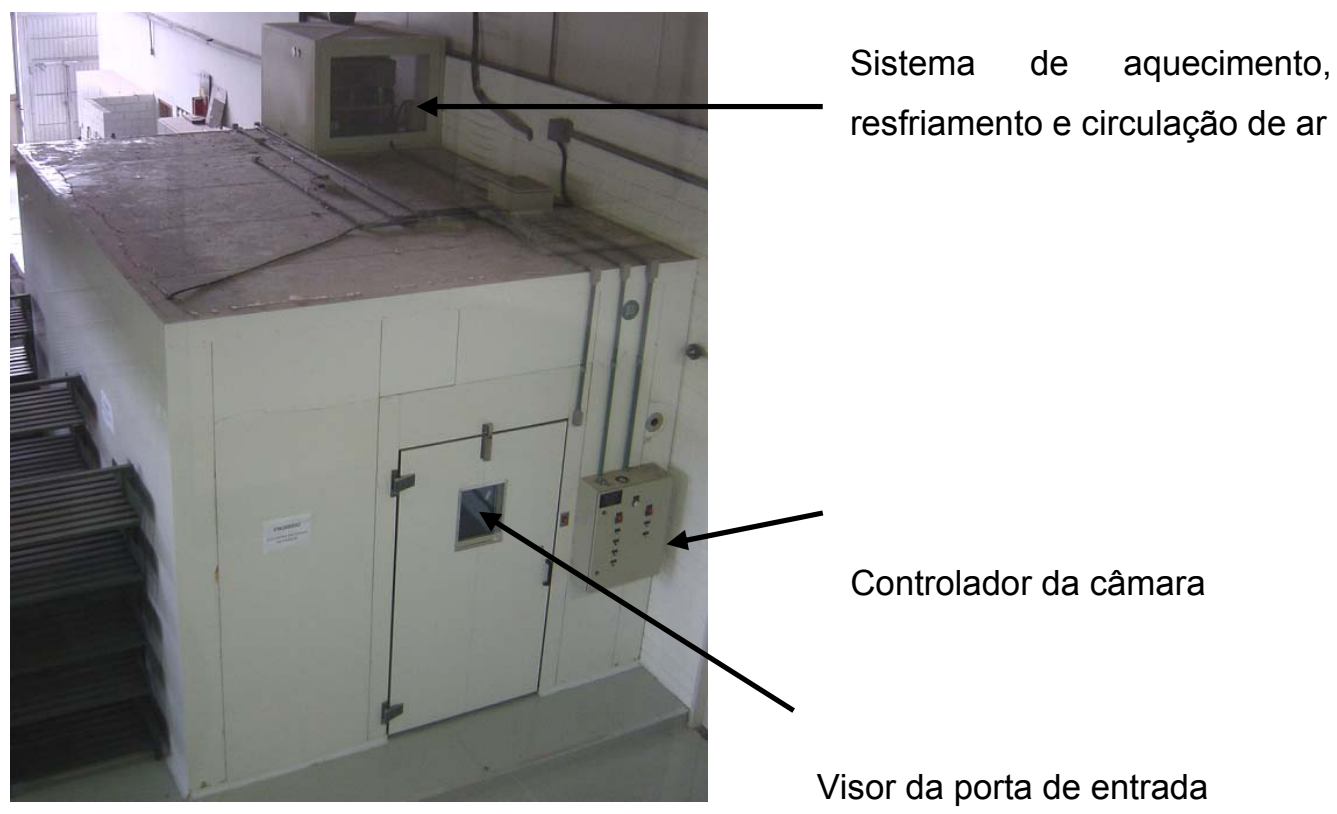

Figura 4.14 - Vista externa da câmara climatizada. 


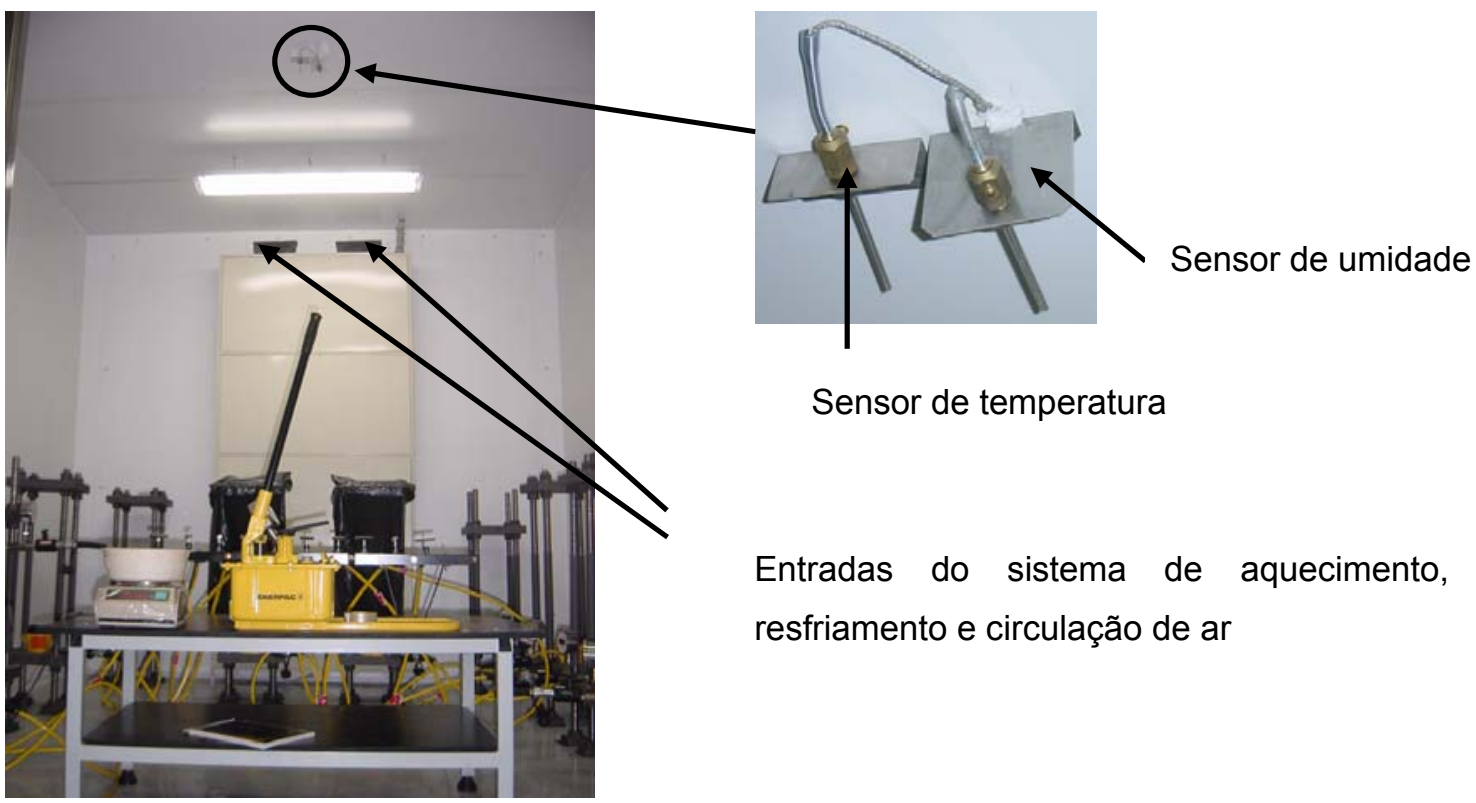

Figura 4.15 - Vista interna da câmara climatizada.

Com a finalidade de verificar manutenção da temperatura $\left(23 \pm 1^{\circ} \mathrm{C}\right)$ e umidade relativa $(60 \pm 3 \%)$ do ambiente da câmara foram realizados dois testes: uniformidade das condições ambientais em toda extensão da câmara (teste 1) e capacidade de manutenção da temperatura e umidade relativa com a abertura da porta (teste 2).

Para o teste 1, dois dataloggers, foram posicionados em pontos distintos da câmara climatizada (um próximo à porta - datalogger 1 - e outro próximo ao sistema de controle de temperatura e umidade relativa - datalogger 2), conforme a figura 4.13. Os dataloggers apresentam incerteza de medição das leituras de temperatura e umidade relativa de $\pm 0,3^{\circ} \mathrm{C}$ e $\pm 2 \%$, respectivamente. Os resultados provenientes dos dataloggers também foram confrontados com as medidas obtidas dos sensores da câmara. Dessa forma, é possível analisar a uniformidade da temperatura e umidade relativa dentro da câmara. Os resultados estão apresentados no gráfico 4.1 . 


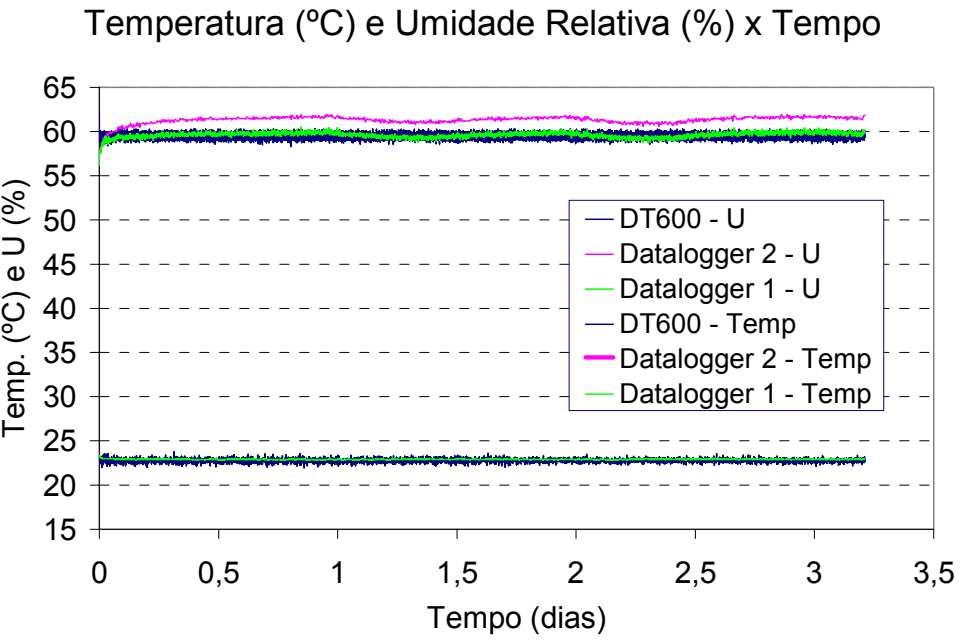

Gráfico 4.1 - Temperatura e umidade relativa ambiente da câmara climatizada.

A temperatura registrada pelos três sensores, como pode ser observada no gráfico 4.1, manteve-se aproximadamente constante e dentro da diferença permitida (23 \pm $1^{\circ} \mathrm{C}$ ). Para umidade relativa, houve uma variação de aproximadamente $2,3 \%$ entre o datalogger 2 e os outros sensores (datalogger 1 e o sensor da câmara). Esta diferença se dá principalmente pelo fato do datalogger 2 estar localizado próximo à saída de umidificação da câmara, aumentado à umidade relativa relativa desta região. Entretanto, mesmo havendo esta diferença de umidade relativa, a variação está dentro da faixa permitida.

O teste 2 foi realizado para verificação da manutenção da temperatura e umidade relativa considerando a possibilidade de abertura da porta por um tempo de 5 minutos. Como a temperatura e umidade relativa externas à câmara estavam aproximadamente iguais, não houve alteração da umidade relativa e temperatura interna. Além disso, a existência de uma cortina termoplástica auxiliou na manutenção da temperatura e umidade relativa interna.

Para o ensaio de retração foi utilizada uma câmara climatizada que já fazia parte da infra-estrutura do Laboratório de Estruturas e Materiais Estruturais - LEM da USP. Esta câmara mantém a temperatura e umidade relativa ambiente constantes de $23 \pm 1^{\circ} \mathrm{C}$ e $50 \pm 3 \%$, respectivamente, com auxílio de um sistema de aquecimento, resfriamento e circulação de ar. Utilizou-se essa câmara, já que a norma seguida para a realização deste ensaio requer que a umidade relativa seja de $50 \%$. 


\subsubsection{Equipamento de aplicação de carga}

O equipamento de carregamento é composto pelos cilindros hidráulicos, mangueiras, manômetros, régua de distribuição, acumuladores hidropneumáticos e bomba manual, como podem ser visto na figura 4.16.

Foram utilizados cilindros ultrabaixos com porca trava, sendo oito cilindros de 65 toneladas e 2 cilindros de 110 toneladas. A bomba é manual de aço com capacidade de reservatório de 7,42 litros, vazão na pressão nominal de 4,75 $\mathrm{cm}^{3} /$ bombada e pressão máxima de trabalho de 700 bar. Os acumuladores são hidropneumáticos com capacidade de 100 a 350 bar e estão acoplados a manômetros cuja faixa de pressão de trabalho é de 0 a 400 bar.

$\mathrm{O}$ conjunto cilindro e bomba estão interligados através da régua de distribuição e mangueiras entre cada bastidor. O sistema de carregamento pode ser visto na figura 4.16 .

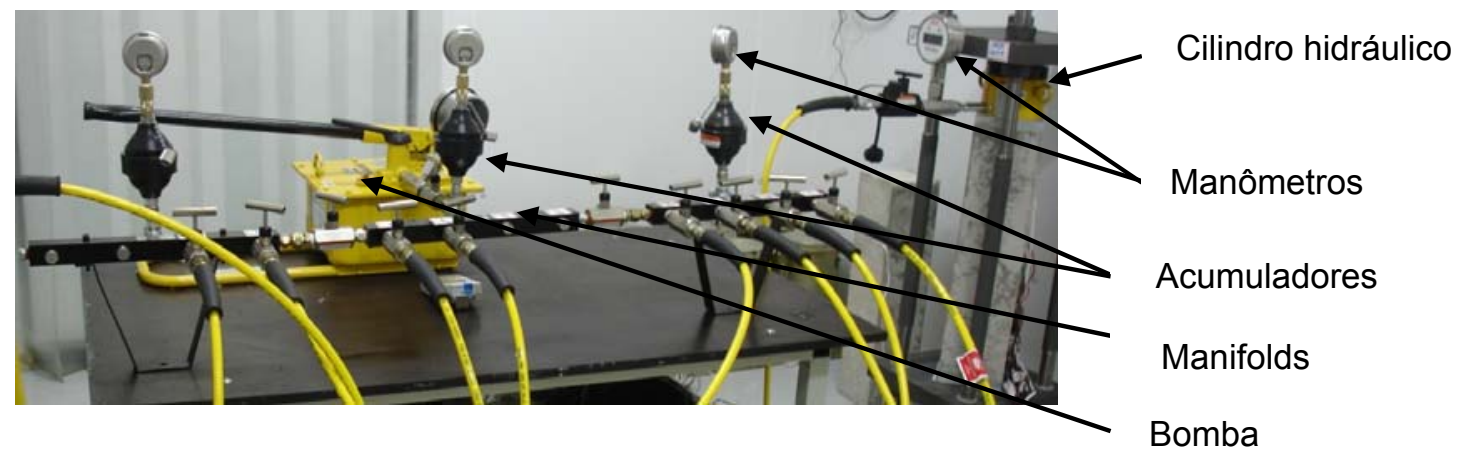

Figura 4.16 - Equipamento de carregamento.

Visando a verificação do comportamento do conjunto, em relação à manutenção de pressão, foi realizado um teste preliminar com um cilindro metálico, considerado praticamente indeformável. Na figura 4.17 pode ser visto o ensaio realizado em um dos bastidores e no gráfico 4.2 as leituras de pressão no manômetro. 


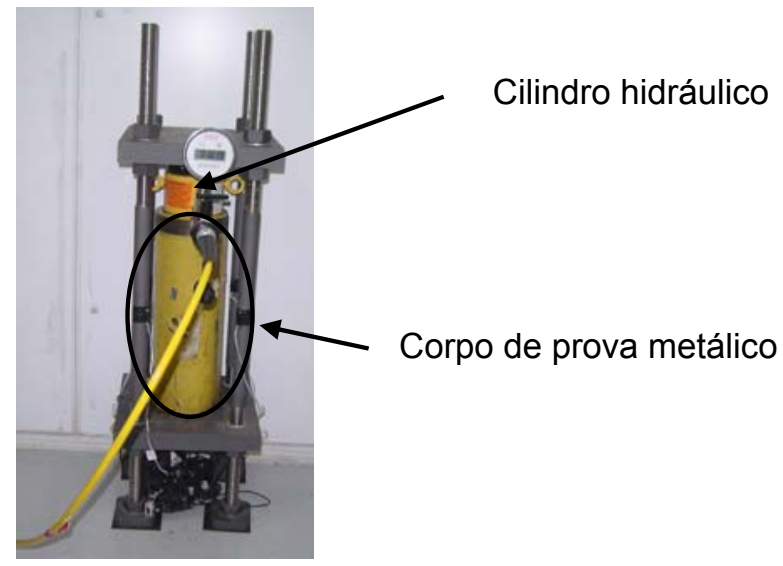

Figura 4.17 - Ensaio de manutenção de pressão no cilindro.

Ensaio com corpo de prova metálico

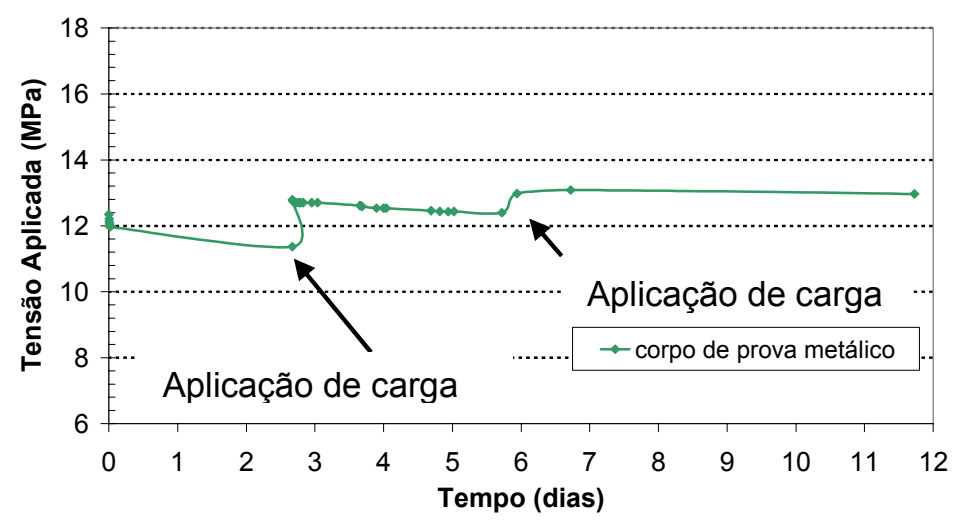

Gráfico 4.2 - Avaliação da manutenção de pressão no cilindro.

Os ensaios para manutenção de pressão foram feitos para uma perda de $\pm 2 \%$ da tensão inicial, o que significou um ajuste de pressão a cada três dias.

\subsection{Metodologia do ensaio de fluência}

O ensaio para determinação da fluência em corpos de prova de concreto exige o conhecimento de técnicas para garantir sua eficiência. Embora a NBR8224 (1983) prescreva um procedimento que vai desde a amostragem até a execução do ensaio, não há especificações detalhadas (materiais e técnicas) de algumas etapas consideradas fundamentais.

Como este ensaio é de longo prazo (mínimo 3 meses) e utiliza, na maioria das vezes, sensores de elevado custo embutidos no concreto para a medição da 
deformação, é imprescindível garantir que a instrumentação, concretagem, desforma, selagem e carregamento sejam feitos de maneira adequada.

Com este intuito, neste item estão descritos as técnicas utilizadas para o ensaio de fluência.

\subsubsection{Instrumentação}

O procedimento adotado para a instrumentação dos corpos de prova foi realizado de acordo com as seguintes etapas:

- Marcação do fio dos sensores com auxílio de fita adesiva crepe de modo a garantir o perfeito posicionamento vertical destes, ou seja, coincidentes ao eixo da fôrma $15 \times 30 \mathrm{~cm}$ (figura 4.18);

- Reforço com fita adesiva crepe do orifício do disco inferior para evitar perda de pasta (figura 4.18);

- Colocação de uma camada de desmoldante ou óleo nas laterais internas da fôrma;

- Passagem dos fios dos sensores pelo disco inferior através do orifício e da ranhura existentes e localizá-los no eixo da fôrma (figura 4.18);

- Colocação de uma faixa de borracha com $2 \mathrm{~mm}$ de espessura nas aberturas laterais da fôrma para evitar vazamento de nata de cimento (figura 4.19);

- Proteção das extremidades dos fios com fita adesiva crepe.

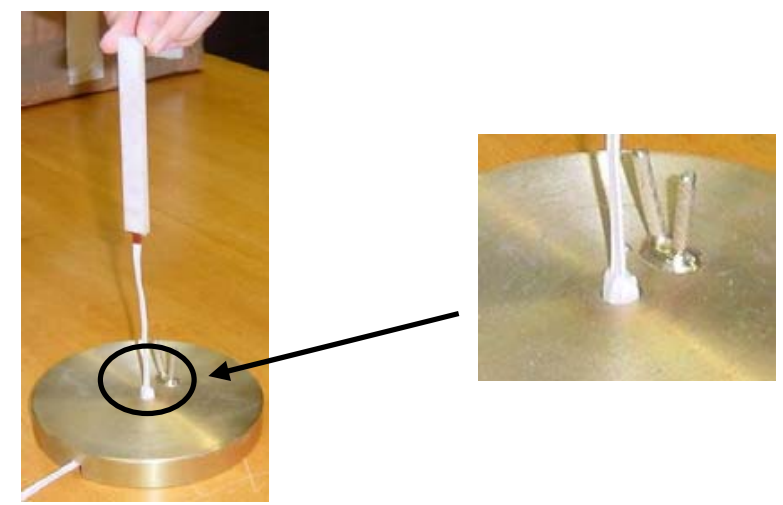

Figura 4.18 - Marcação do fio do sensor e reforço do orifício do disco.

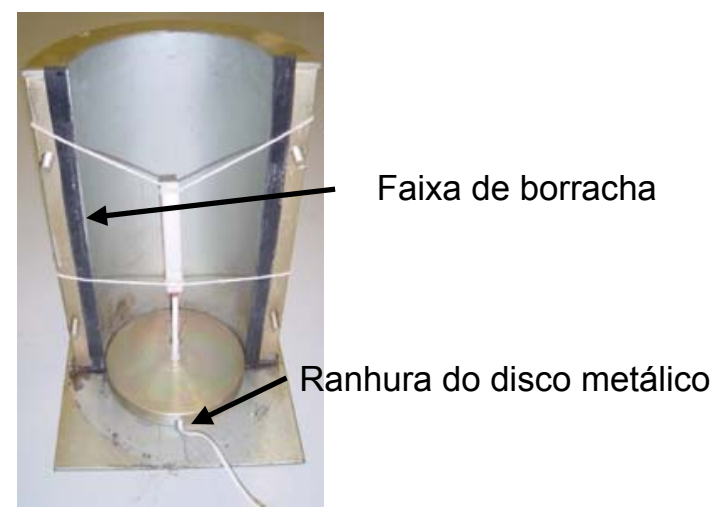

Figura 4.19 - Vedação da forma com uma camada de cera. 


\subsubsection{Moldagem}

Duas séries de ensaios foram moldadas: fluência por secagem (não selados) e fluência básica (selados). Em cada série foi composta por 3 corpos de prova cilíndricos com dimensões de $15 \times 30 \mathrm{~cm}$, sendo dois corpos de prova carregados e um utilizado como compensador do ensaio (retração por secagem e autógena). Nos corpos de prova moldados com o Traço II foi feito somente o ensaio de fluência por secagem. A moldagem foi feita de acordo com a NBR5738 (2003). Durante a moldagem foi tomado cuidado especial com o adensamento de forma a evitar o deslocamento dos sensores do eixo da fôrma. Para tanto, a quantidade de golpes foi igualmente distribuída nas duas metades da fôrma. Após a moldagem, ainda com o concreto fresco, o disco superior foi colocado de modo a garantir sua planicidade com auxílio de um nível de bolha (figura 4.20).

Os corpos de prova foram mantidos em câmara úmida de acordo com a NBR5738 (2003) até a data de ensaio.

Caso na desmoldagem o disco superior se destacasse dos corpos de prova, estes foram fixados novamente utilizando gesso seguindo as recomendações do fabricante, conforme figura 4.21. É importante manter a planicidade do disco, utilizando nível de bolha.

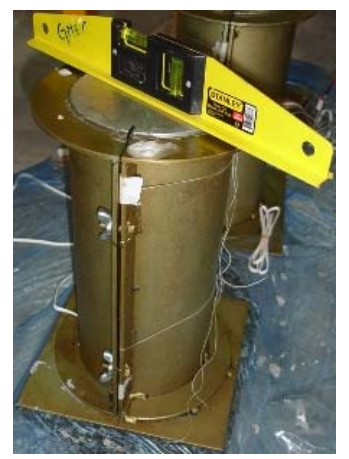

Figura 4.20 - Nivelamento do disco superior.

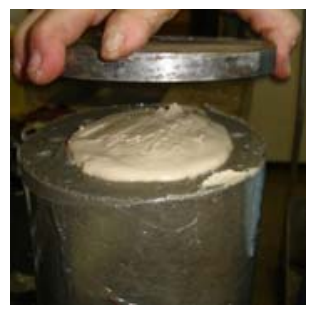

Figura 4.21 - Fixação do disco superior utilizando gesso. 


\subsubsection{Selagem}

$\mathrm{Na}$ desforma, os corpos de prova destinados ao ensaio de fluência básica receberam um tipo de proteção (selagem) para evitar troca de umidade com o ambiente e deformações de retração por secagem.

O procedimento iniciou-se com o envolvimento do corpo de prova por, pelo menos, 5 camadas de filme plástico. Em seguida, o corpo de prova foi envolvido com fita adesiva de alumínio sobreposta. Nas extremidades, superior e inferior, na mesma posição dos discos metálicos, foram colocados anéis metálicos ajustáveis (figura 4.22).

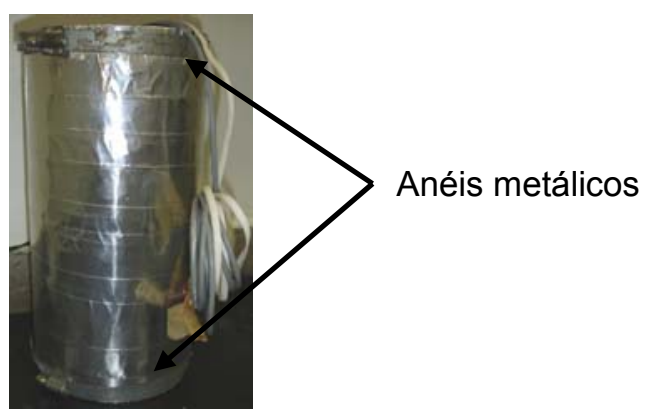

Figura 4.22 - Selagem com fita adesiva.

Após a selagem foram colocadas etiquetas nos corpos de prova contendo as seguintes informações: numeração, data de moldagem, data de carregamento e idade do corpo de prova.

\subsubsection{Carregamento}

Os corpos de prova foram carregados com 7 dias de idade a $20 \%$ e a $40 \%$ da sua resistência média à compressão. Foram aplicados dois carregamentos e descarregamentos simultâneos. Em seguida, o bastidor foi mantido em repouso por um período de pelo menos $1 \mathrm{~min}$. Finalmente, foi aplicada a carga estabelecida no ensaio. 


\subsubsection{Monitoração}

Antes da aplicação do carregamento, foi feita uma leitura das deformações dos corpos de prova em repouso. A deformação imediata é a leitura feita 30s após a aplicação do terceiro carregamento. Para as deformações subseqüentes as medidas devem ser feitas na seguinte seqüência: $5 \mathrm{~min}, 10 \mathrm{~min}, 30 \mathrm{~min}, 1 \mathrm{~h}, 2 \mathrm{~h}, 5 \mathrm{~h}$, diariamente durante uma semana, duas vezes por semana até completar um mês e semanalmente até o fim do ensaio.

Segundo Carreira e Burg (2000), o ensaio de fluência deve ser feito no mínimo para 91 dias. Entretanto, afirmam que dependendo da sensibilidade da estrutura analisada as propriedades de fluência e retração, o período mínimo de duração destes ensaios pode ser de 45 dias. Bažant (2001) sugere um período mínimo de monitoração de 91 dias, pois os resultados experimentais medidos por este período de tempo ( 3 meses) são importantes para reduzir a incerteza dependente dos parâmetros de entrada em modelos de previsão. Nesta pesquisa, a taxa de aquisição utilizada foi de 30 s no primeiro dia e $1 \mathrm{~h}$ até o fim do ensaio (91 dias).

Todos os corpos de prova de fluência básica e fluência por secagem foram acondicionados na câmara climatizada de fluência durante todo o ensaio.

Os ensaios de fluência básica e por secagem e o esquema de monitoração de uma série de ensaio podem ser vistos nas figuras $4.23,4.24$ e 4.25 , respectivamente.

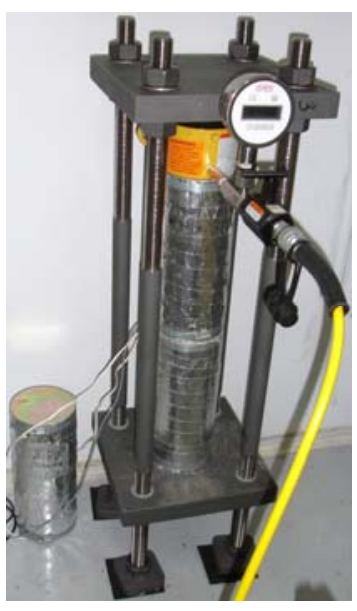

Figura 4.23 - Ensaio de fluência básica.

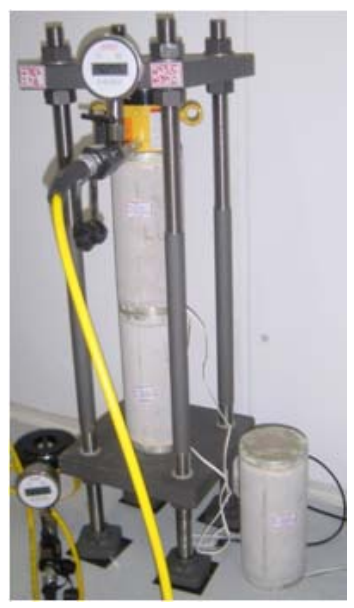

Figura 4.24 - Ensaio de fluência por secagem. 


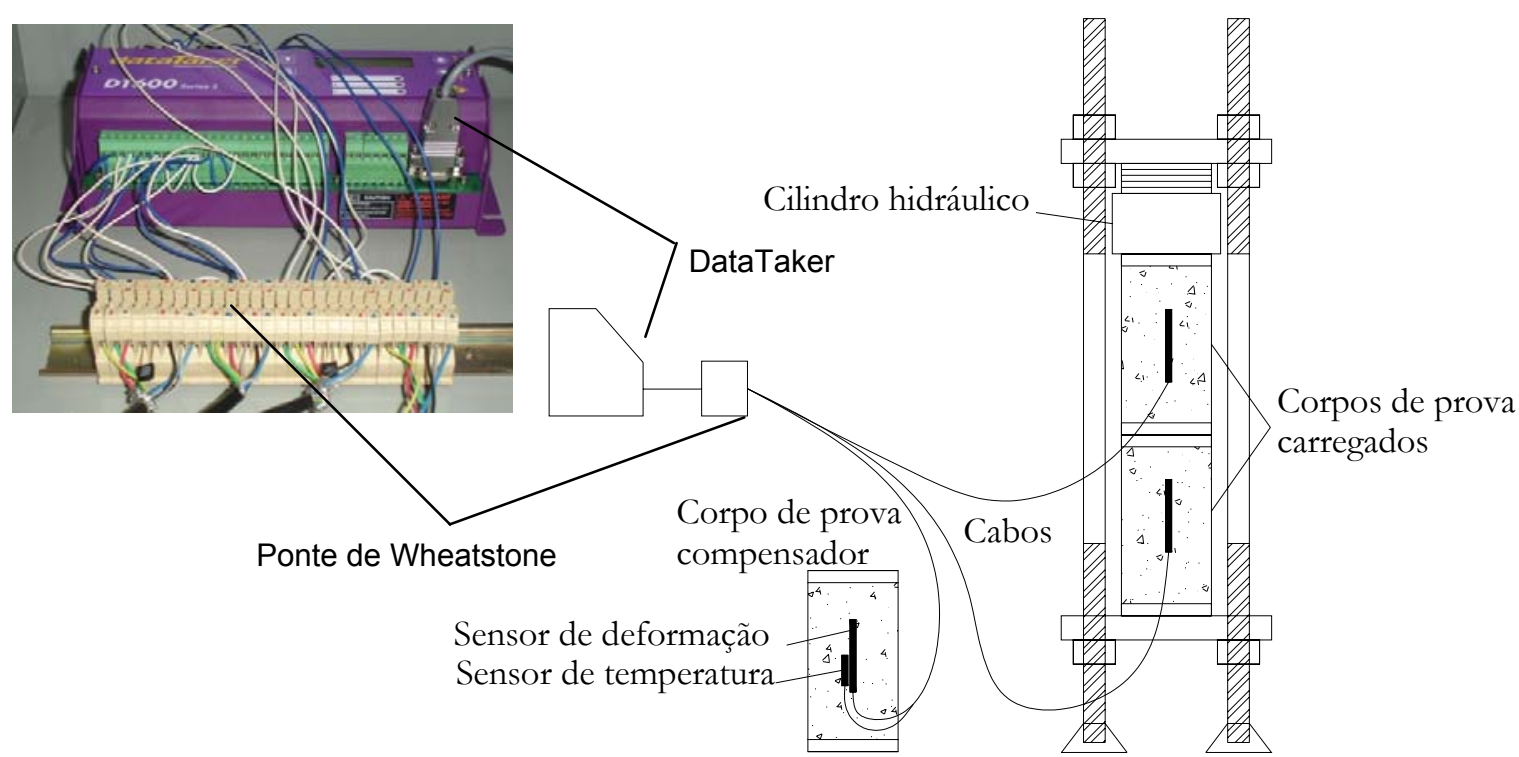

Figura 4.25 - Esquema de monitoração de uma série de ensaio de fluência (sem escala).

\subsubsection{Cálculo das deformações por fluência}

Os resultados experimentais obtidos do ensaio de fluência correspondem à deformação total, ou seja, a somatória da deformação inicial, de retração (por secagem e/ou autógena) e por fluência (por secagem e/ou básica).

Na NBR8224 (1983) a deformação por fluência é calculada pela eq.(4-1).

$\varepsilon_{c c}=\varepsilon_{t}-\varepsilon_{i}-\varepsilon_{s}$

$\varepsilon_{c c}$ - deformação por fluência

$\varepsilon_{t}$ - deformação total a partir da leitura de referência, nos corpos de prova sob carregamento, na idade considerada

$\varepsilon_{i}$ - deformação imediata no ato da aplicação da carga

$\varepsilon_{s}$ - deformação média dos corpos de prova complementares não submetidos a carregamento

A deformação de fluência por secagem $\left(\varepsilon_{c c, s}\right)$ foi obtida pela diferença da deformação dos corpos de prova não selados carregados $\left(\varepsilon_{c s}\right)$ pela deformação de retração dos corpos de prova não selados $\left(\varepsilon_{s s}\right)$ dada pela eq.(4-2). A deformação de fluência básica $\left(\varepsilon_{c c, b}\right)$ foi obtida pela diferença da deformação dos corpos de prova selados carregados $\left(\varepsilon_{c b}\right)$ pela deformação por retração autógena $\left(\varepsilon_{s a}\right)$ dada 
pela eq.(4-3). A parcela instantânea elástica $\left(\varepsilon_{i}\right)$ não foi descontada da deformação total.

$$
\begin{gathered}
\varepsilon_{c c, s}=\varepsilon_{c s}-\varepsilon_{s s} \\
\varepsilon_{c c, b}=\varepsilon_{c b}-\varepsilon_{s a}
\end{gathered}
$$

Nesta pesquisa, os resultados de caracterização dos corpos de prova foram apresentados na unidade de fluência específica $\times 10^{-6} / \mathrm{MPa}^{1}$. Atualmente, esta unidade é a mais utilizada internacionalmente, facilitando a comparação e análise de resultados de outros trabalhos realizados.

As análises dos resultados dos protótipos de pilares foram apresentadas em unidade de deformação $\times 10^{-6}$, pois o objetivo é avaliar a deformação total (fluência e retração).

Cabe ressaltar que a NBR8224 (1983) sugere que sejam feitos apenas ensaios de fluência básica. Esta norma também determina que as condições de ensaio (temperatura e umidade relativa) possam ser especificadas em função das necessidades do projeto e obra (MARQUES; KATAOKA, 2009). Entretanto, é fundamental abranger $\mathrm{O}$ ensaio de fluência por secagem visto que diversas estruturas apresentam esta propriedade. Além disso, a padronização das condições de ensaio permite que resultados provenientes de diferentes concretos possam ser comparados.

\subsection{Metodologia do ensaio de retração}

A propriedade da retração é de elevada complexidade e há a necessidade de aprofundar seu entendimento em estruturas de concreto, contribuindo para a determinação de parâmetros fundamentais para os modelos numéricos de previsão do comportamento estrutural. Este ensaio tem com objetivo fornecer subsídios e parâmetros para a análise numérica e aprimoramento do dimensionamento de estruturas reais. Para análise da retração, foram confeccionados os traços I, III e IV descritos no item 4.1.

Neste item estão descritos os procedimentos utilizados para realização dos ensaios de retração por secagem em corpos de prova prismáticos. 


\subsubsection{Moldagem}

O ensaio de retração por secagem foram realizados em corpos de prova prismáticos $(10 \times 10 \times 28 \mathrm{~cm})$ com o objetivo de caracterizar o seu comportamento no estado livre.

Antes da execução da moldagem dos corpos de prova, foi passado desmoldante na forma e colocado os pinos de medida, tomando-se o devido cuidado de mantêlos limpos e sem óleo, pois isto pode interferir na aderência do pino no concreto.

A distância interna livre entre os pinos, de acordo com a NBRNM131 (1998) e ASTM C490 (1997), deve ser de 250,0 $\pm 2,5 \mathrm{~mm}$. Esta distância não foi facilmente alcançada, porque o pino pode ficar demasiadamente apertado no apoio. Quando isto ocorria, ao desenroscá-lo, o corpo de prova trincava na região onde estava localizado o pino durante a operação de desmoldagem. Portanto, a distância adotada foi a mais adequada e próxima possível da distância especificada em norma.

A moldagem foi feita em duas camadas. Cada camada foi adensada com aproximadamente 15 golpes distribuídos ao longo da forma com auxílio da haste plástica (figura 4.26). Após o adensamento, alguns golpes foram distribuídos externamente ao redor da forma utilizando um martelo de borracha (figura 4.27). Após o adensamento, para garantir a planicidade da superfície dos corpos de prova, é utilizada uma régua metálica para "sarrafear" a superfície do concreto (figura 4.28). Os corpos de prova moldados foram mantidos nas formas, devidamente protegidos contra a perda de umidade relativa para o ambiente por meio da utilização de plásticos por 24 horas.

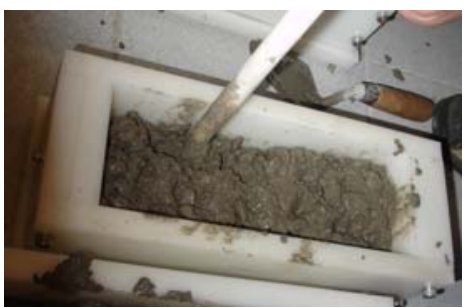

Figura 4.26 - Adensamento com haste plástica.

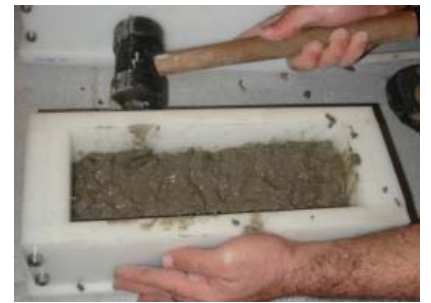

Figura 4.27 - Adensamento com martelo de borracha.

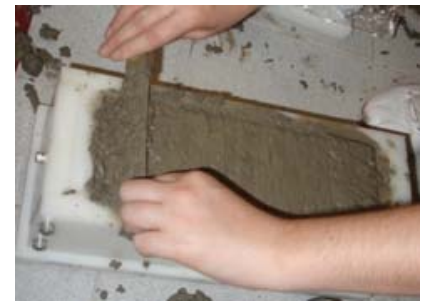

Figura 4.28 - Acabamento com haste plástica. 


\subsubsection{Desmoldagem}

Os corpos de prova foram desmoldados após 24h. Logo após a desforma, para que não houvesse desprendimento dos pinos existentes nas extremidades dos corpos de prova, foi colocada uma fina camada de cola de secagem rápida em torno dos pinos, conforme figuras 4.29 e 4.30 . É importante ressaltar que a desmoldagem foi feita individualmente para não expor as superfícies dos corpos de prova à secagem.

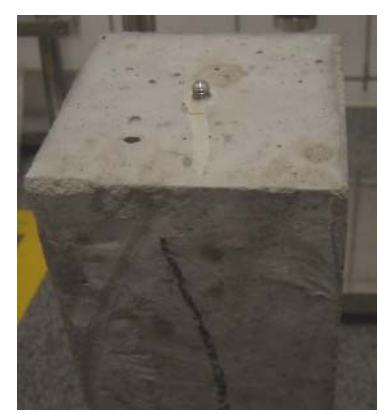

Figura 4.29 - Topo do corpo de prova de retração.

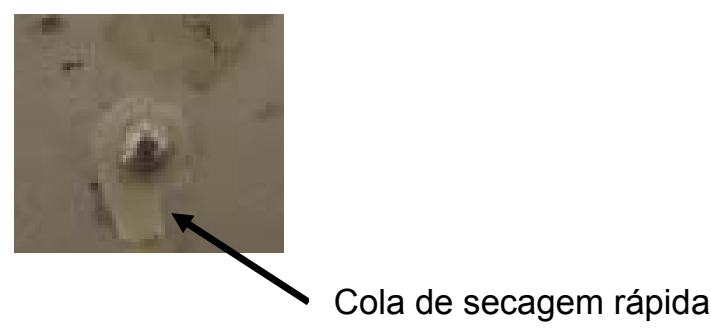

Figura 4.30 - Fixação dos pinos na desmoldagem.

\subsubsection{Monitoração}

Após a desforma, foram feitas as leituras de referência da dimensão inicial $\left(L_{i}\right)$ dos corpos de prova destinados ao ensaio de retração por secagem. Após a aferição, o corpo de prova foi encaixado verticalmente na base metálica, tomando-se o cuidado de posicioná-lo sempre em um mesmo sentido. É aconselhado fazer uma indicação por meio de uma seta nos corpos de prova.

Em seguida, girou-se o corpo de prova sobre o eixo e registrou-se a menor medida indicada pelo relógio comparador. O importante é sempre manter o mesmo padrão. Este giro é essencial para que o erro devido à excentricidade do corpo de prova seja minimizado. Após a leitura, foi realizada a pesagem dos corpos de prova, determinando a variação de massa com precisão de décimos de miligrama.

A leitura da variação dimensional foi realizada de 1 até 7 dias, depois aos $9,11,14$, $21,28,35,42,56,63,126$ e 91 dias. É importante ressaltar que, deve haver um 
número considerável de corpos de prova devido à grande dispersão dos resultados obtidos por este procedimento experimental. Nesta pesquisa, as leituras foram feitas até 154 dias.

Todos os corpos de prova de retração por secagem foram acondicionados na câmara climatizada de retração, durante todo o ensaio. Os corpos de prova foram posicionados na câmara de modo que houvesse circulação de ar em todas as faces do mesmo. O ensaio de retração por secagem pode ser visto na figura 4.31.

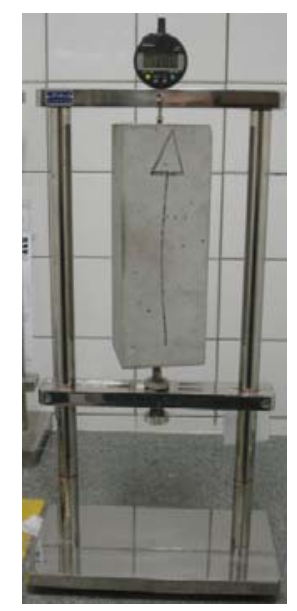

Figura 4.31 - Ensaio de retração pro secagem.

\subsubsection{Cálculo das deformações por retração}

O cálculo da variação de comprimento dos corpos de prova de retração $(\Delta L / L)$ foi realizado através da eq.(4-4):

$\frac{\Delta \mathrm{L}}{\mathrm{L}}=\frac{\left(\mathrm{L}_{\mathrm{xi}}-\mathrm{L}_{\mathrm{i}}\right)}{\mathrm{G}} \times 100$

$L_{i}$ - leitura inicial do comprimento do corpo de prova $(\mathrm{mm})$

$L_{x i}$ - demais leituras do comprimento, feitas em intervalos de tempo prédeterminados $(\mathrm{mm})$

$G$ - distância interna entre os pinos (figura 4.6b)

Este cálculo fornece a medida da variação de comprimento linear em porcentagem. Entretanto, esta unidade de medida dificulta a análise dos resultados. Portanto, 
assim como para fluência, com a finalidade de facilitar a comparação e análise adotou-se a utilização da unidade de $\times 10^{-6}$.

\subsection{Metodologia do ensaio dos protótipos de pilares}

Neste item são apresentados os procedimentos relativos à parte experimental dos protótipos de pilares, ou seja, a determinação do traço de concreto, a caracterização das barras de aço, a definição dos modelos dos protótipos e o procedimento de ensaio de fluência.

As dimensões dos protótipos foram definidas de forma a adequá-los aos bastidores de fluência já existentes no laboratório. Portanto, foram ensaiados à fluência e retração protótipos de pilares curtos $(\lambda=14)$ com seção transversal de $15 \times 15 \mathrm{~cm}$, considerando carga centrada.

\subsubsection{Definição dos protótipos}

Foram ensaiados à fluência e retração 9 protótipos de pilares em concreto simples e armado com mesmas dimensões, considerando constante a taxa de armadura transversal e duas taxas de armadura longitudinais de $2,8 \%$ e $1,4 \%$. Os protótipos ensaiados à fluência foram carregados aos 7 dias com $40 \%$ e $30 \%$ da resistência média à compressão desta idade. Além dos pilares carregados, também foram ensaiados pilares sem carregamento para determinação da deformação por retração. A retração foi medida a partir dos 7 dias mantendo as mesmas condições de cura dos outros protótipos. Variando a taxa de armadura é possível avaliar a influência da armadura na restrição às deformações de fluência e retração.

A classe de resistência utilizada para o ensaio experimental dos pilares foi definida como $30 \mathrm{MPa}$ (Traço II) descrito no item 4.1. Atualmente, esta classe de resistência é bastante empregada em estruturas de concreto. 
As dimensões dos pilares foram limitadas pelas dimensões dos bastidores em que foram ensaiados. Portanto, o pilar tem seção transversal quadrada de $15 \times 15 \mathrm{~cm}$ e altura de $60 \mathrm{~cm}$. Além disso, as dimensões dos pilares foram escolhidas de forma que as relações volume superfície $(V / S)$ e área da seção transversal perímetro da seção transversal $(A d u)$ fossem as mesmas que dos corpos de prova cilíndricos, ou seja, de 3,75. Estas relações consideram a geometria do elemento nos modelos de previsão analisados nesta pesquisa. Dessa forma, é possível avaliar a eficiência deste parâmetro na formulação dos modelos para o caso estudado.

Foi utilizada uma nomenclatura para designar cada protótipo. A nomenclatura inicia-se com uma letra que indica o tipo de ensaio (fluência - $F$ ou retração - $R$ ) seguida por dois dígitos que representam a porcentagem de carregamento aplicada aos 7 dias (30 ou 40\%). Na seqüência, há dois dígitos que indicam a taxa de armadura longitudinal em porcentagem $(2,8,1,4$ ou $0,0 \%)$. Finalmente, um único dígito é utilizado para especificar o número do protótipo dentro de um grupo de pilares idênticos (1 ou 2). Um exemplo da nomenclatura utilizada é dado por F402,8-2. Trata-se de um pilar ensaiado à fluência a $40 \%$ da resistência média à compressão aos 7 dias, com taxa de armadura longitudinal de $2,8 \%$ e é o segundo do grupo de pilares idênticos.

Os números de protótipos ensaiados à fluência e retração podem ser vistos na tabela 4.9 .

Tabela 4.9 - Número de protótipos de pilares.

\begin{tabular}{cccccc}
\hline Taxa armadura (\%) & \multicolumn{2}{c}{2,8} & \multicolumn{2}{c}{1,4} & 0 \\
\hline Carregamento (\%) & 30 & 40 & 30 & 40 & 40 \\
\hline Fluência & 1 & 2 & 1 & 1 & 1 \\
Retração & \multicolumn{2}{c}{1} & & 1 & 1 \\
\hline
\end{tabular}

A taxa de armadura, a tensão aplicada aos 7 dias e o grupo a qual o protótipo de pilar pertence estão apresentadas na tabela 4.10. 
Tabela 4.10 - Detalhes dos protótipos de pilares.

\begin{tabular}{cccc}
\hline Nomenclatura & $\begin{array}{c}\text { Taxa de armadura } \\
\text { longitudinal (\%) }\end{array}$ & $\begin{array}{c}\text { Tensão aos } 7 \\
\text { dias (MPa) }\end{array}$ & Grupo \\
\hline F40-2,8-1 & 2,8 & 10,5 & 1 \\
F40-2,8-2 & 2,8 & 10,5 & 2 \\
F30-2,8-1 & 2,8 & 8,03 & 1 \\
F40-1,4-1 & 1,4 & 10,5 & 1 \\
F30-1,4-1 & 1,4 & 8,03 & 1 \\
F40-0,0-1 & 0,0 & 10,5 & 1 \\
R-2,8-1 & 2,8 & - & 1 \\
R-1,4-1 & 1,4 & - & 1 \\
R-0,0-1 & 0,0 & - & 1 \\
\hline
\end{tabular}

\subsubsection{Detalhamento das armaduras}

O detalhamento da armadura longitudinal e transversal inicia-se com a escolha dos diâmetros. Foram adotados para as armaduras longitudinais e transversais os diâmetros nominais mínimos prescritos na NBR6118 (2004) de $10 \mathrm{~mm}$ e 5 mm, respectivamente. Para a armadura longitudinal e transversal foram adotados os diâmetros de $10 \mathrm{~mm}$, com comprimento de $56 \mathrm{~cm}$ cada e de $6,3 \mathrm{~mm}$, com comprimento de $54 \mathrm{~cm}$ cada, respectivamente.

Segundo a NBR6118 (2004) item 17.3.5.3.1, o valor mínimo da taxa de armadura longitudinal de pilares pode ser expresso pela eq.(4-5). A taxa máxima dada pela eq.(4-6) é de $8 \%$ da área da seção transversal do pilar (item 17.3.5.3) ou $4 \%$ nas seções de transpasse.

$$
\begin{aligned}
& \rho_{\text {min }}=0,15 \cdot \frac{N_{d}}{f_{y d}} \geq 0,40 \% \cdot A_{c} \\
& \rho_{\text {min }}=0,15 \cdot \frac{749250}{500 / 1,15} \geq 0,004 \cdot 15 \cdot 15 \\
& \rho_{\text {min }}=2,58 \geq 0,9 \mathrm{~cm}^{2} \\
& A_{s, \text { max }}=\frac{4}{100} \cdot 15 \cdot 15=9 \mathrm{~cm}^{2}
\end{aligned}
$$


Como o protótipo do pilar possui seção transversal de $15 \times 15 \mathrm{~cm}$, há necessidade de posicionar, no mínimo, 4 armaduras nas extremidades dos estribos como porta estribos, que corresponde a $1,4 \%$ de taxa de armadura. Portanto, nesta pesquisa foram adotadas duas taxas de armadura longitudinal de $2,8 \%$ e $1,4 \%$.

Em seguida, é determinado o cobrimento de concreto mínimo prescrito em norma. De acordo com a NBR6118 (2004) tabela 6.1 item 6.4.3, para pilar que vai ser executado em ambiente seco e protegido de chuva, utiliza-se a classe de agressividade ambiental II. Além disso, as dimensões das armaduras e os espaçadores devem respeitar os cobrimentos nominais, estabelecidos na tabela 7.2 item 7.4.7.2, para $\Delta c=10 \mathrm{~mm}$. Para pilares em concreto armado e classe de agressividade ambiental II, este cobrimento nominal é igual a $30 \mathrm{~mm}$. Dessa forma, o cobrimento mínimo é dado pela eq.(4-7):

$c_{\text {min }}=c_{\text {nom }}-10 \mathrm{~mm}$

$c_{\text {min }}=20 \mathrm{~mm}$

Assim, os pilares em concreto armado e classe de agressividade ambiental II devem ter cobrimento mínimo de $20 \mathrm{~mm}$.

Os espaçamentos livres entre as armaduras máximo e mínimo estão prescritos no item 18.4.2.2 da NBR6118 (2004). Estes espaçamentos são medidos no plano da seção transversal, fora da região de emendas são dados pelas eq.(4-8) e eq.(4-9), respectivamente.

Espaçamento mínimo:

$e_{\text {min }} \geq\left\{\begin{array}{l}2 \mathrm{~cm} \\ \phi_{l}=1 \mathrm{~cm} \\ 1,2 . \phi_{\text {agregado, } \text { máx }}=1,2.1,9=2,28 \mathrm{~cm}\end{array}\right.$

Espaçamento máximo:

$e_{\text {máx }} \geq\left\{\begin{array}{l}2 . b=2.15=30 \mathrm{~cm} \\ 40 \mathrm{~cm}\end{array}\right.$

O espaçamento longitudinal entre estribos deve ser inferior ou igual ao menor dos seguintes valores dados pela eq.(4-10) item 18.4.3, da NBR6118 (2004). 
$s \leq\left\{\begin{array}{l}20 \mathrm{~cm} \\ b=15 \mathrm{~cm} \\ 12 \phi_{l} \text { paraCA }-50=12.1=12 \mathrm{~cm}\end{array}\right.$

b - menor dimensão do pilar

Portanto, o espaçamento longitudinal dos estribos deve ser no máximo $12 \mathrm{~cm}$. 0 detalhamento dos pilares com taxas de armadura de 2,8\% e 1,4\% está apresentado na figura 4.32 .

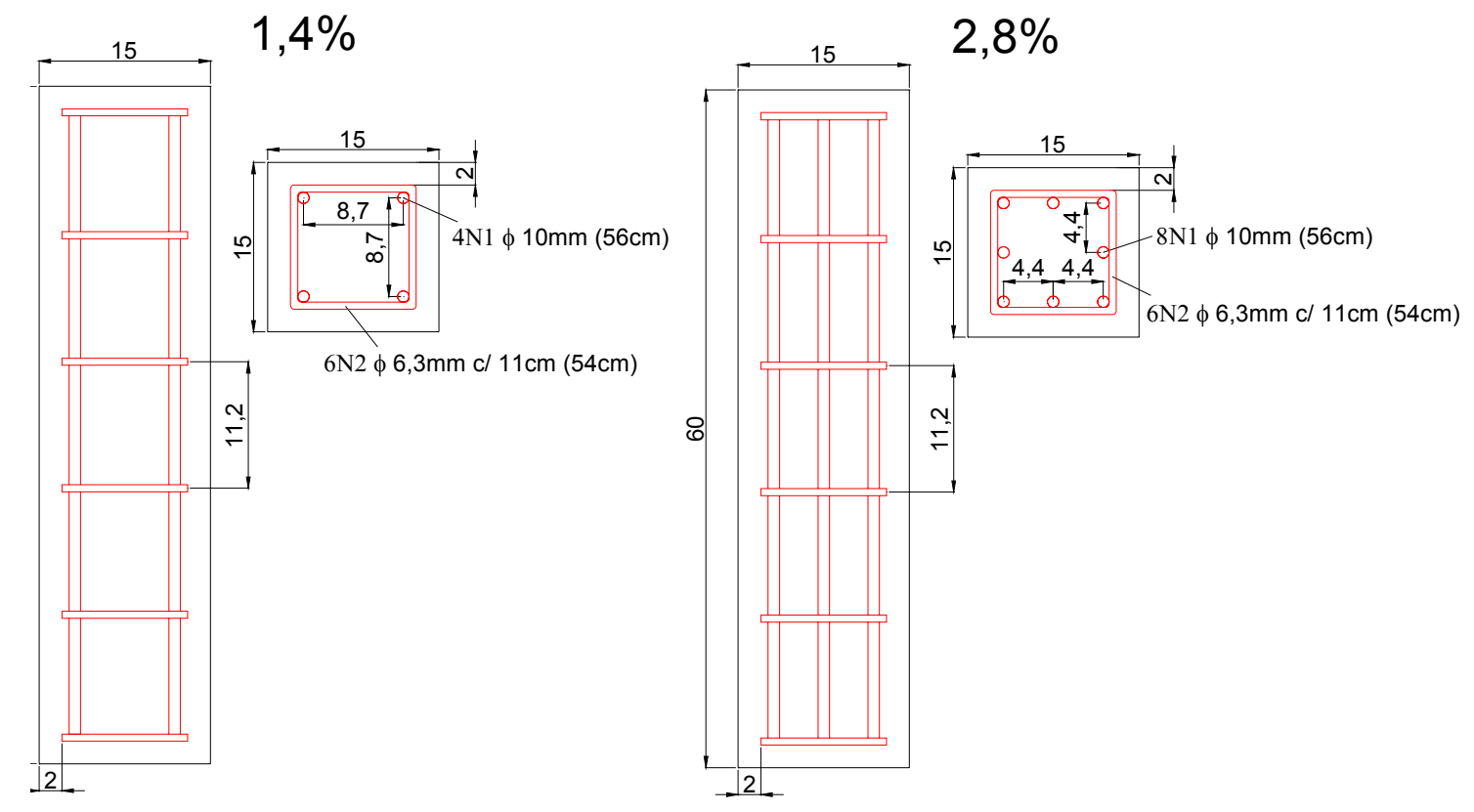

Figura 4.32 - Detalhamento dos pilares com taxa de armadura 2,8 e 1,4\%.

De acordo com Richart e Staehle (1931); Slater e Lyse (1931); Lyse e Kreidler (1932) é possível considerar que a variação da taxa de estribos tem efeito desprezível na fluência e retração, considerando baixas tensões e resistência do concreto. Além disso, Roy e Sozen (1965) observaram que estribos retangulares não aumentam a resistência do concreto. Takeuti (2003) afirma que o efeito do confinamento é particularmente interessante na fase pré-pico de ruptura para pilares de concreto de baixa resistência. Portanto, não foi feita a análise do efeito de confinamento nesta pesquisa.

As barras de aço de $6,3 \mathrm{~mm}$ e $10 \mathrm{~mm}$ foram ensaiadas de acordo com NBR7480 (2008). Para cada diâmetro foi utilizado dois corpos de prova de $30 \mathrm{~cm}$ de comprimento, instalando-se relógio comparador para medição dos deslocamentos. 
A tabela 4.11 apresenta as propriedades físicas e mecânicas das armaduras estudadas.

Tabela 4.11 - Propriedades físicas e mecânicas das armaduras.

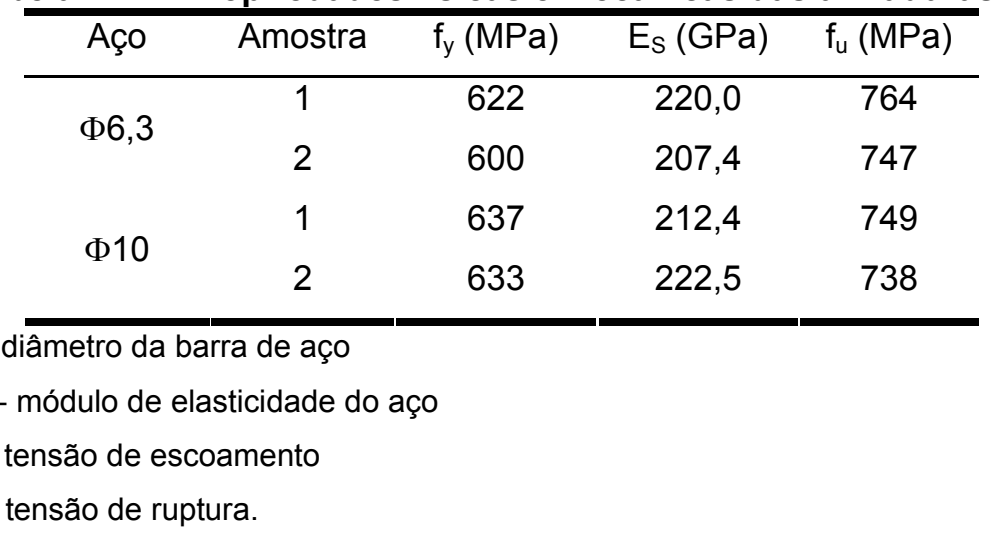

\subsubsection{Instrumentação}

A medição das deformações nas armaduras dos protótipos foi feita por meio de sensores elétricos de resistência de colagem e as deformações do concreto foram medidas utilizando sensores elétricos de imersão, descritos no item 4.3.4. Tanto o sensor de armadura quanto o de concreto foram posicionados a meia altura do pilar. Cada barra longitudinal foi instrumentada em faces opostas. O posicionamento longitudinal e nas seções transversais dos sensores nos protótipos pode ser visto nas figuras 4.33 , respectivamente. Na figura 4.34 , a posição dos sensores é representada por um número que também corresponde à numeração da armadura. 


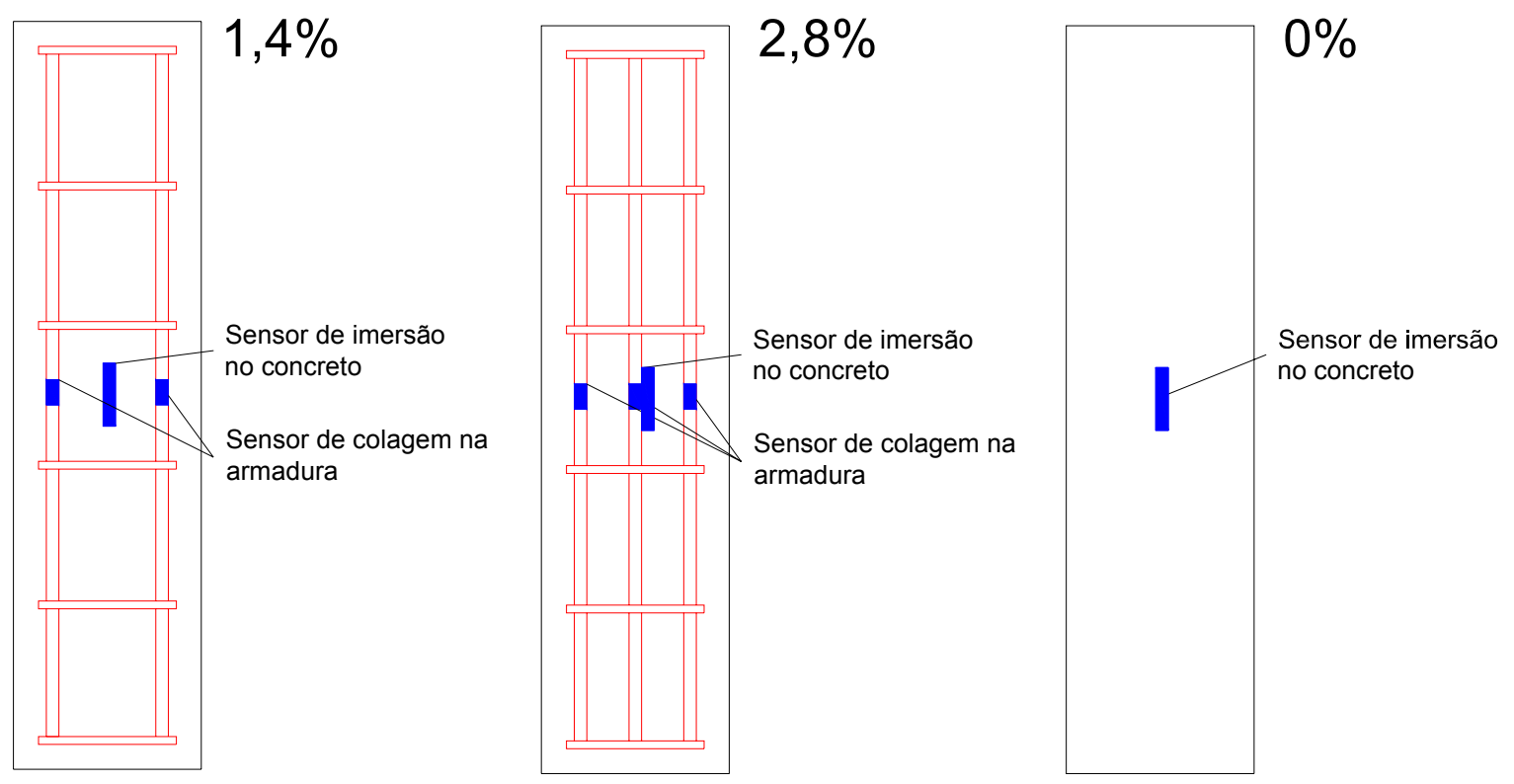

Figura 4.33 - Instrumentação longitudinal dos protótipos de pilares.
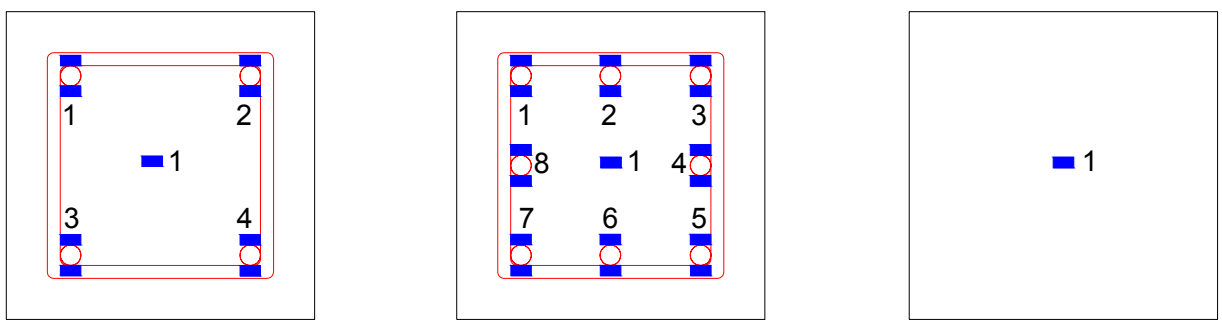

Figura 4.34 - Instrumentação transversal dos protótipos de pilares.

\subsubsection{INSTRUMENTAÇÃO DAS ARMADURAS}

Todas as armaduras longitudinais foram instrumentadas em faces opostas a meia altura do eixo longitudinal de forma a eliminar o efeito da temperatura e obter medidas médias de deformação no ponto desejado. Primeiramente, as armaduras foram medidas e marcadas para determinar a posição do sensor. Em seguida, foi feita a preparação da superfície para colagem dos sensores e terminais. A preparação da superfície consiste em limar, lixar e limpar a posição onde as armaduras foram marcadas. Finalmente, as armaduras foram instrumentadas e os fios soldados. 
A preparação da superfície de colagem iniciou-se com a limagem. Primeiramente, a limagem foi feita utilizando lima grossa em movimentos semicirculares e perpendiculares ao eixo para retirar as mossas da barra. Em seguida, foi feito o mesmo movimento semicircular utilizando lima fina, porém com movimentos a $45^{\circ}$ do eixo, com a finalidade de preparar a superfície para o acabamento.

As áreas limadas foram lixadas utilizando o mesmo processo da lima fina. Inicialmente, foi utilizada lixa de grana 220 cortada em fita com aproximadamente $1 \times 15 \mathrm{~cm}$. Em seguida, a barra foi lixada usando lixa de grana 320 até que a superfície estivesse lisa e brilhante, como pode ser visto na figura 4.35.

Depois de lixadas, foi feita uma limpeza superficial utilizando lenços de papel umedecidos em álcool isopropílico até que a superfície da barra estivesse sem resíduos para colagem. Em seguida, foi feita a marcação do centro do eixo longitudinal superior e inferior da barra para definir a posição do sensor.

Para auxiliar no posicionamento do sensor foi utilizada fita adesiva transparente. Após o posicionamento, foi aplicada cola à base de éster de cianoacrilato na superfície da barra e no verso do sensor e este foi pressionado por mais de 2 minutos com o auxílio de uma fita teflon. Após a colagem, foi medida sua resistência para verificar se este está em curto-circuito com a barra.

Em seguida, foram fixados os terminais e as vias dos sensores foram soldadas numa extremidade do terminal. $O$ processo de colagem do terminal foi o mesmo adotado para os sensores. Os terminais devem estar próximos dos sensores para evitar que a ligação entre eles dê curto-circuito.

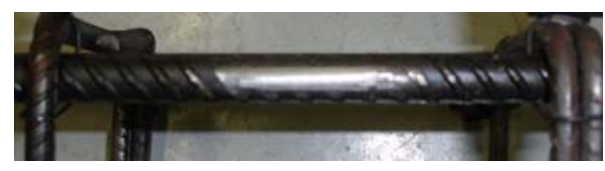

Figura 4.35 - Superfície da armadura preparada para colagem do sensor.

$\mathrm{Na}$ outra extremidade do terminal foram soldados fios com aproximadamente 50 $\mathrm{cm}$ de comprimento e $1,5 \mathrm{~mm}$ de diâmetro nominal para conectá-los no equipamento de aquisição de dados (DT600 e DT800).

Depois que os dois lados da barra foram instrumentados, foi necessário proteger as áreas para evitar possíveis danos mecânicos e contato com a umidade do 
concreto. A proteção foi feita em duas camadas. Primeiramente foi utilizada cola epóxi e depois fita de autofusão (figura 4.36).

Ao fim desse processo também foi necessário testar a resistência do sensor. Caso este esteja em curto-circuito com a barra, será necessário removê-lo e instrumentar novamente a barra seguindo o processo descrito neste item. Para garantir 0 cobrimento do concreto de $2 \mathrm{~cm}$, foram utilizados espaçadores (figura 4.37).

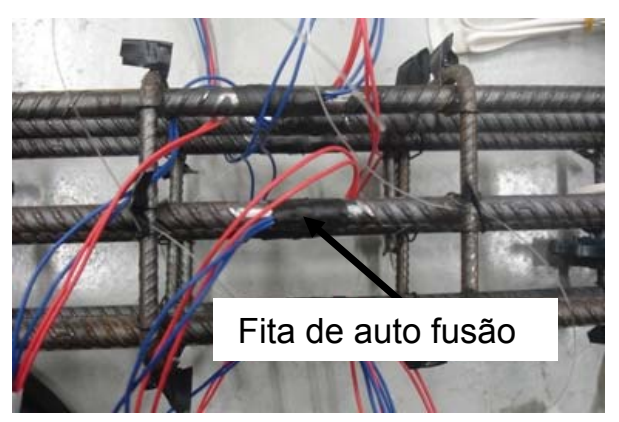

Figura 4.36 - Proteção dos sensores da armadura.

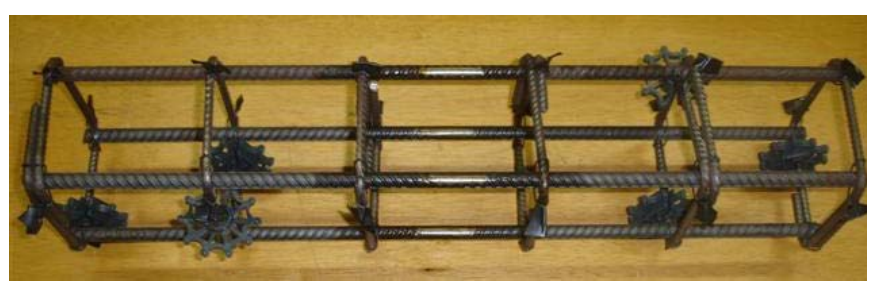

Figura 4.37 - Posicionamento dos espaçadores.

\subsubsection{INSTRUMENTAÇÃO DO CONCRETO}

Os sensores de imersão em concreto para medição da deformação dos pilares sem armadura foram instalados nas formas. Estes foram centralizados por meio de dois furos em cada lateral da forma (figura 4.38). Nos pilares armados, o sensor de concreto foi centralizado fixando-o na armadura utilizando fio de nylon com 0,6 mm de diâmetro. O posicionamento deste pode ser visto na figura 4.39.

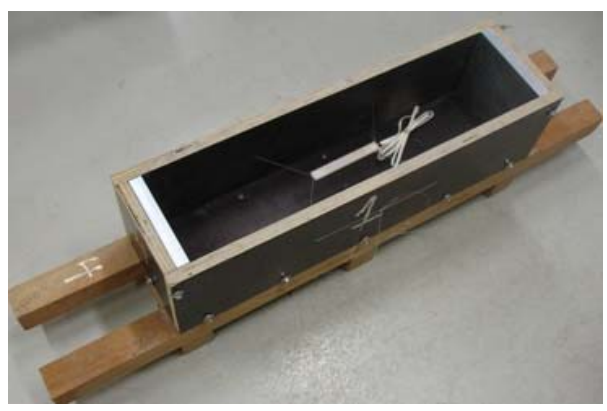

Figura 4.38 - Posicionamento dos sensores de imersão no concreto.

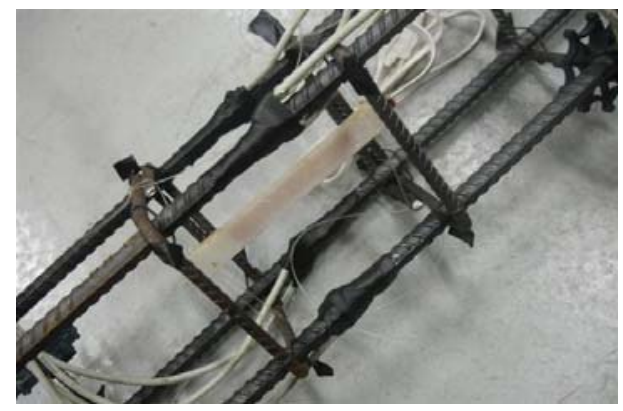

Figura 4.39 - Sensor de concreto centralizado na armadura. 
As configurações finais da instrumentação dos protótipos de pilares com taxas de 2,8 e $1,4 \%$ de armadura longitudinal podem ser vistas nas figuras 4.40 e 4.41 .

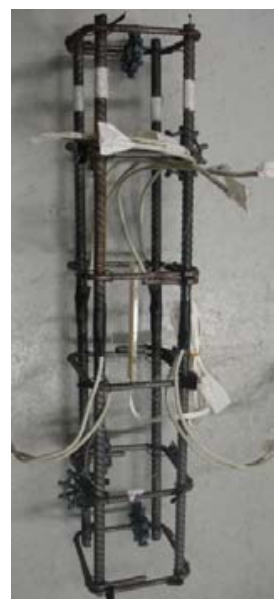

Figura 4.40 - Instrumentação dos protótipos com taxa de $2,8 \%$ de armadura longitudinal.

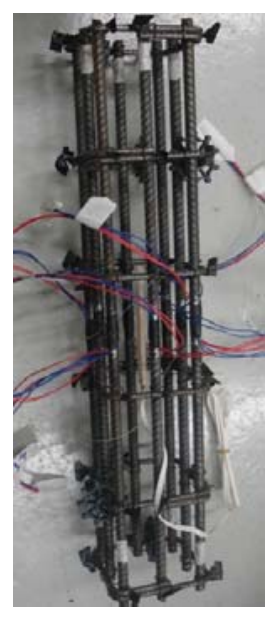

Figura 4.41 - Instrumentação dos protótipos com taxa de $1,4 \%$ de armadura longitudinal

\subsubsection{Formas}

Foram feitas formas horizontais com seção retangular e dimensões de $15 \times 15$ x 64 $\mathrm{cm}$. A altura das formas é superior a do pilar, pois foram posicionadas em suas extremidades chapas metálicas ou de polipropileno com $2 \mathrm{~cm}$ de espessura concretadas juntamente com o protótipo. Dessa forma, na configuração final, os pilares tiveram altura de $60 \mathrm{~cm}$. As chapas metálicas (figura 4.42) foram utilizadas nos protótipos destinados ao ensaio de fluência de modo a garantir, após a concretagem, a planicidade para aplicação uniforme da carga e o posicionamento centralizado do macaco hidráulico utilizado para aplicação da carga. As chapas de polipropileno (figura 4.43) foram utilizadas no ensaio de retração para permitir que a superfície exposta à secagem fosse apenas as laterais dos protótipos, simulando a retração dos protótipos carregados. Na figura 4.44 está apresentado o projeto da forma utilizada nesta pesquisa. As dimensões estão em mm. 


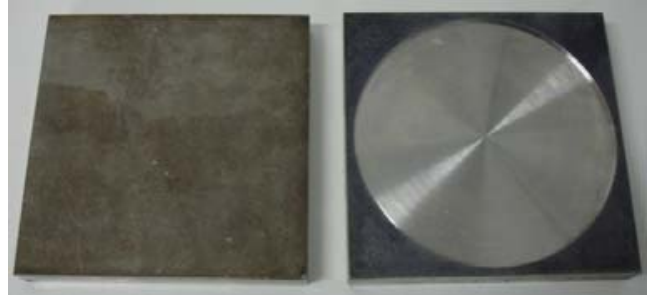

Figura 4.42 - Chapas metálicas.

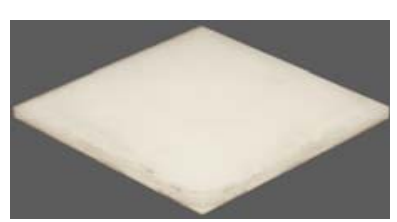

Figura 4.43 - Chapas de polipropileno.

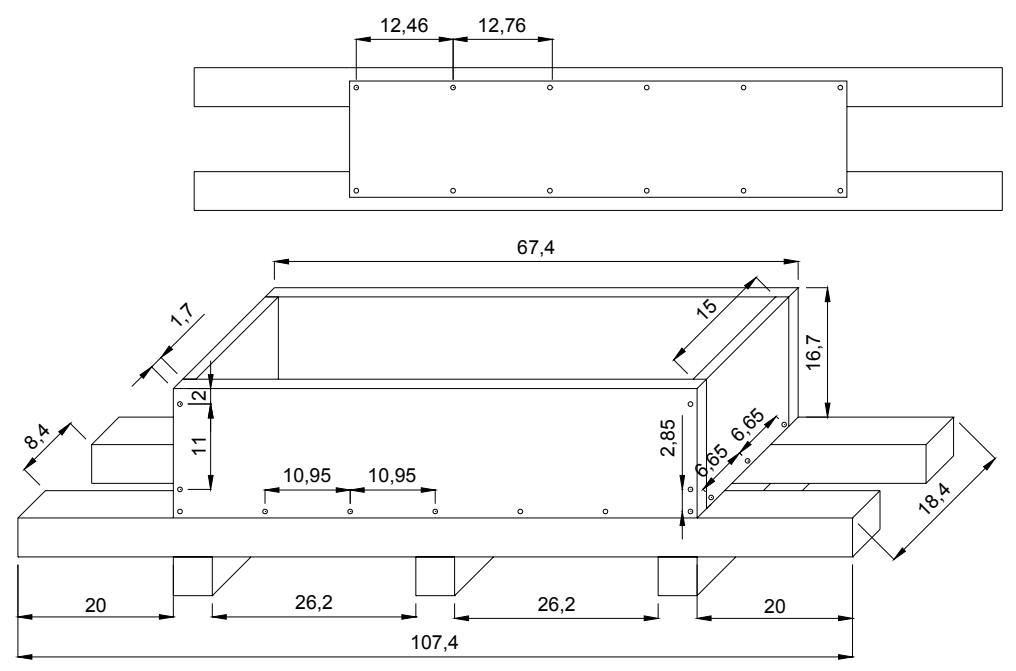

Figura 4.44 - Formas de madeira.

\subsubsection{Moldagem}

Foram utilizadas as mesmas prescrições de normas descritas no item 4.4.2 para moldagem, desforma, cura e determinação das propriedades do concreto no estado fresco. Houve apenas distinção no procedimento de adensamento que foi feito utilizando vibrador mecânico, tanto para os protótipos quanto para os corpos de prova.

A moldagem foi feita em duas etapas. Primeiramente foram moldados os pilares F40-2,8-1, F40-1,4-1, F40-0,0-1, R-2,8-1, R-1,4-1 e R-0,0-1. Na segunda etapa, foram moldados os pilares F40-2,8-2, F30-2,8-1 e F30-1,4-1.

Juntamente com os protótipos de pilares, foram moldados 3 corpos de prova cilíndricos $15 \times 30 \mathrm{~cm}$, sendo dois destinados ao ensaios de fluência por secagem e um para retração por secagem. Também foram moldados 36 corpos de prova cilíndricos $10 \times 20 \mathrm{~cm}$ para caracterização à resistência média à compressão, o 
módulo de elasticidade e resistência à tração por compressão diametral para 7, 28, 61 e 91 dias. As figuras 4.45 e 4.46 ilustram a moldagem dos pilares e corpos de prova cilíndricos. Os ensaios de resistência à compressão e módulo de elasticidade seguem as prescrições das normas descritas no item 4.1.

Um dia após a moldagem, os pilares foram mantidos em cura úmida onde permaneceram por sete dias. Os corpos de prova foram desmoldados um dia após a moldagem e permaneceram em câmara úmida até a data do ensaio.

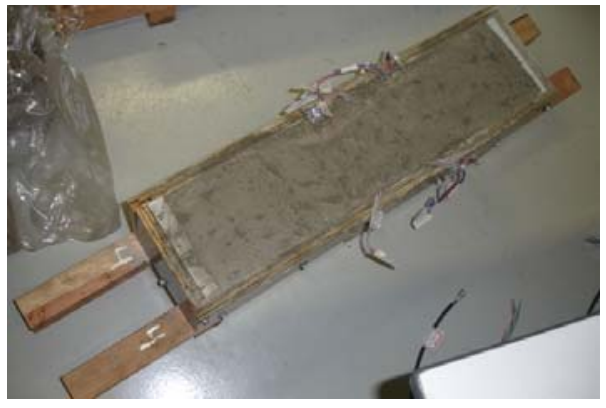

Figura 4.45 - Moldagem dos protótipos de pilares.

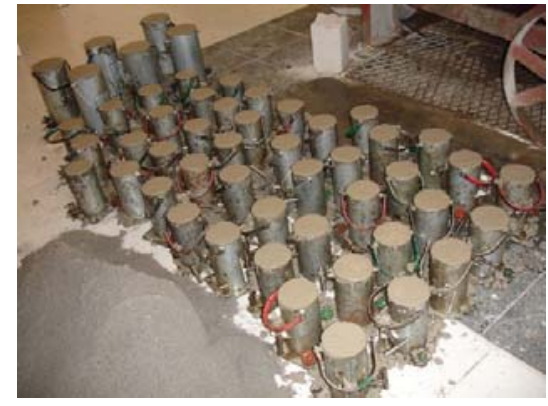

Figura 4.46 - Moldagem dos corpos de prova cilíndricos.

\subsubsection{Equipamento de ensaio e monitoração}

Os protótipos foram ensaiados na câmara climatizada com temperatura e umidade relativa constantes de $23 \pm 1^{\circ} \mathrm{C}$ e $60 \pm 4 \%$. A tensão aplicada nos protótipos foi de $40 \pm 2 \%$ ou $30 \pm 2 \%$ da resistência média à compressão aos 7 dias de idade. Os protótipos foram carregados nos bastidores de fluência utilizando cilíndricos hidráulicos. Os ensaios foram realizados em dois tipos de bastidores: simples (figura 4.47a), na qual havia apenas um protótipo por bastidor e duplo (figura 4.47b), na qual havia dois protótipos por bastidor. Para evitar flambagem dos pilares ensaiados no bastidor duplo foi projetada uma placa deslizante com encaixe localizado entre os protótipos, como pode ser visto na figura 4.47b. A monitoração das deformações foi feita utilizando DataTaker modelo DT600 e DT800. Os materiais e equipamentos utilizados neste ensaio estão descritos no item 4.3. 

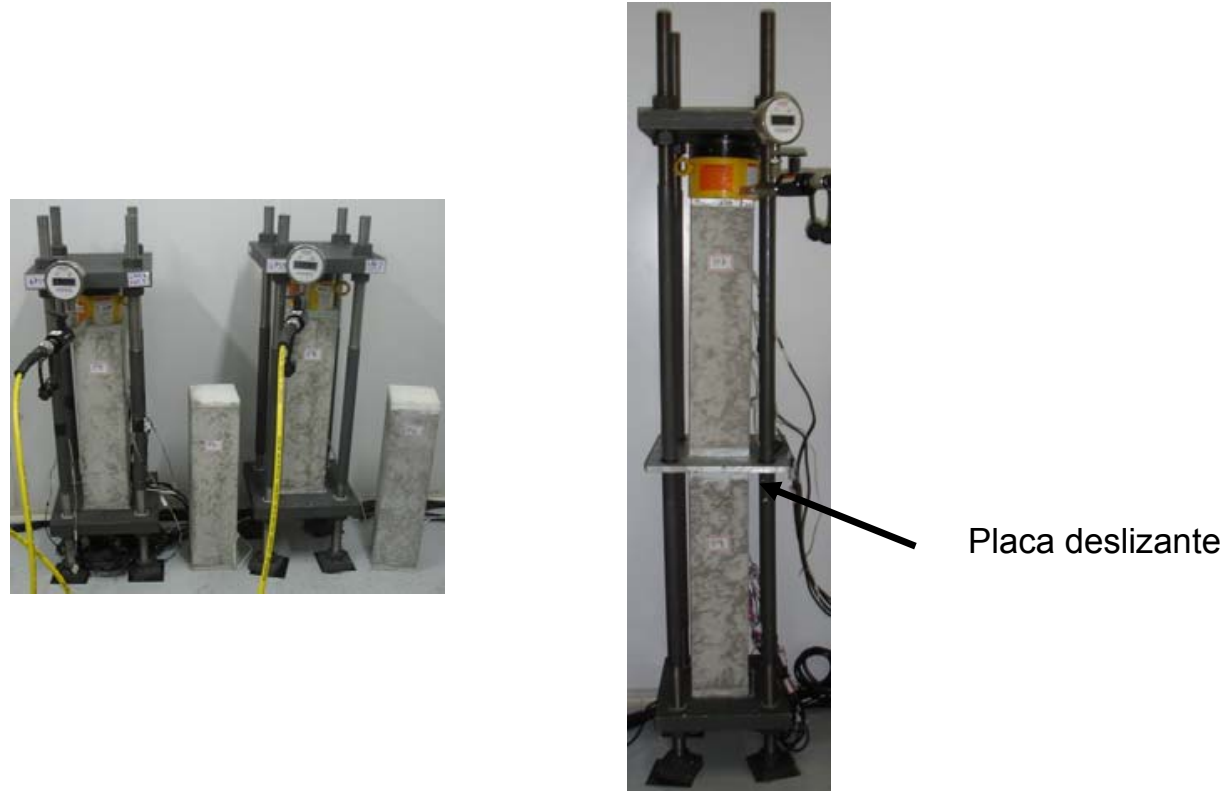

a) Bastidor simples

b) Bastidor duplo

Figura 4.47 - Ensaio de fluência dos protótipos de pilares. 


\section{CAPÍTULO 5}

\section{RESULTADOS E ANÁLISES DOS ENSAIOS EXPERIMENTAIS}

Este capítulo apresenta os resultados obtidos dos ensaios de fluência e retração em corpos de prova (primeira e segunda etapa) e dos protótipos de pilares (segunda etapa), descritos no capítulo 4.

Os resultados experimentais dos corpos de prova foram confrontados com resultados analíticos dos modelos de previsão teóricos descritos capítulo $2(\mathrm{ACl}$, EC2, NBR, B3 e GL). Além disso, foi feita uma análise da eficiência dos modelos em relação aos resultados experimentais utilizando os coeficientes de variação estatísticos $\omega_{\mathbf{B} 3}$ e $\omega_{B 3, \text { all }}$, descritos no capítulo 2 .

Neste capítulo também foram analisados os resultados experimentais dos protótipos de pilares com relação à transferência de carga do concreto para armadura e à influência da taxa de armadura devido à fluência e retração.

\subsection{Propriedades do concreto no estado fresco}

Os resultados das propriedades do concreto no estado fresco estão apresentados na tabela 5.1.

Tabela 5.1 - Propriedades do concreto fresco.

\begin{tabular}{ccccc}
\hline Componentes & Traço I & Traço II & Traço III & Traço IV \\
\hline Ar aprisionado $(\%)$ & 2,9 & 3,9 & 1,5 & 1,9 \\
Abatimento $(\mathrm{cm})$ & 119 & 132 & 95 & 80 \\
Peso específico $\left(\mathrm{kg} / \mathrm{m}^{3}\right)$ & 2320 & 2362 & 2407 & 2421 \\
\hline
\end{tabular}




\subsection{Propriedades mecânicas do concreto}

A média dos resultados obtidos da resistência à compressão, resistência à tração por compressão diametral e módulo de elasticidade para os concretos estudados estão apresentados na tabela 5.2.

Tabela 5.2 - Propriedades mecânicas dos traços I, II, III e IV.

\begin{tabular}{ccccccc}
\hline \multirow{2}{*}{ Propriedades mecânicas } & \multirow{2}{*}{ Traço } & \multicolumn{5}{c}{ Idade (dias) } \\
\cline { 3 - 7 } & & 7 & 28 & 63 & 91 & 126 \\
\hline \multirow{2}{*}{ Resistência à compressão } & I & 21,6 & 28,2 & 32,4 & 32,2 & 33,5 \\
(MPa) & II & 26,2 & 33,3 & 35,6 & 38,1 & - \\
& III & 46,7 & 56,3 & 58,6 & 61,4 & 60,4 \\
Resistência à tração (MPa) & IV & 52,9 & 58,3 & 61,5 & - & - \\
\cline { 2 - 6 } & I & 2,4 & 3,1 & 3,0 & 3,2 & - \\
& III & 3,0 & 3,8 & 3,5 & 4,0 & - \\
Módulo de elasticidade & IV & 3,9 & 4,9 & 4,7 & - & - \\
\cline { 2 - 6 } (GPa) & I & 21,2 & 28,7 & 27,2 & 28,5 & 28,3 \\
& III & 26,8 & 29,8 & 30,7 & 33,9 & - \\
& IV & 33,8 & 33,2 & 32,6 & 32,9 & 34,3 \\
& & & 33,3 & 38,0 & - & - \\
\hline
\end{tabular}

A partir das propriedades mecânicas é possível notar que a taxa de crescimento tanto da resistência média à compressão quanto do módulo de elasticidade é maior até os 28 dias. Além disso, é possível notar que com a diminuição da relação água cimento há crescimento considerável da resistência média à compressão. O mesmo não ocorre com a resistência à tração que não aumenta na mesma proporção que a resistência à compressão.

\subsection{Fluência em corpos de prova}

Este item apresenta os resultados experimentais de fluência e retração de corpos de prova para os Traços I, II e III, assim como a análise dos resultados experimentais com modelos numéricos. 


\subsubsection{Resultados experimentais}

A deformação por fluência foi obtida pelo carregamento a $20 \%$ da resistência média à compressão dos corpos de prova com 7 dias de idade para o Traço I e a $40 \%$ para os Traços II e III. Os resultados experimentais de deformação total (CPs selados e não selados) e por retração (secagem e autógena) em corpos de prova cilíndricos até 91 dias estão apresentados nos gráficos 5.1, 5.2 e 5.3.

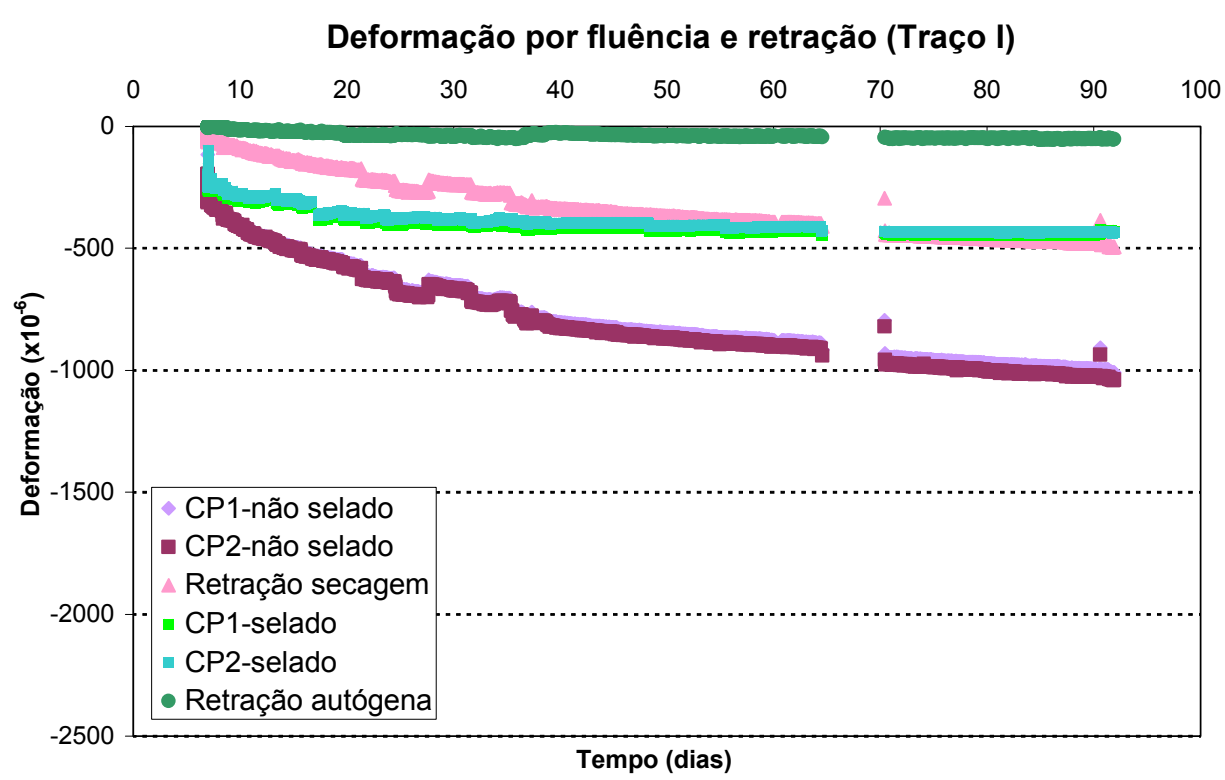

Gráfico 5.1 - Deformação por fluência e retração do concreto (Traço I). 


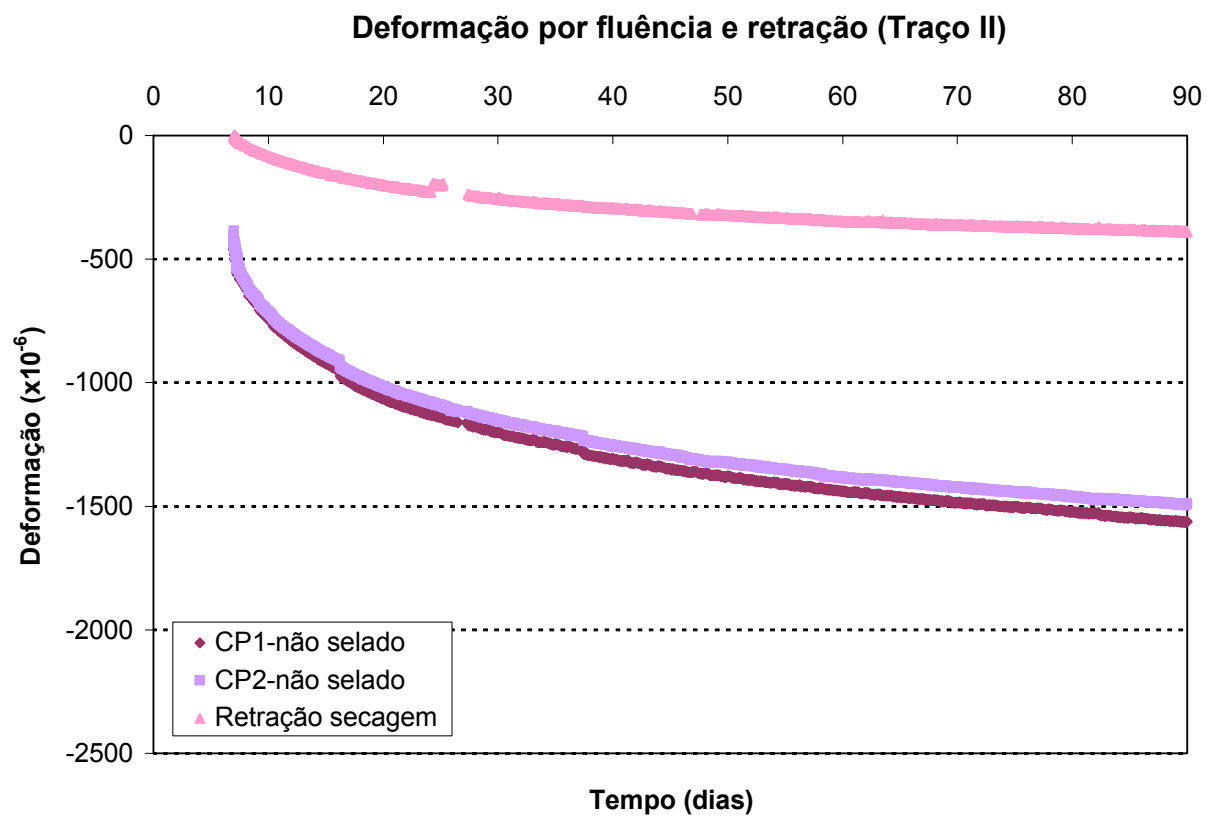

Gráfico 5.2 - Deformação por fluência e retração do concreto (Traço II).

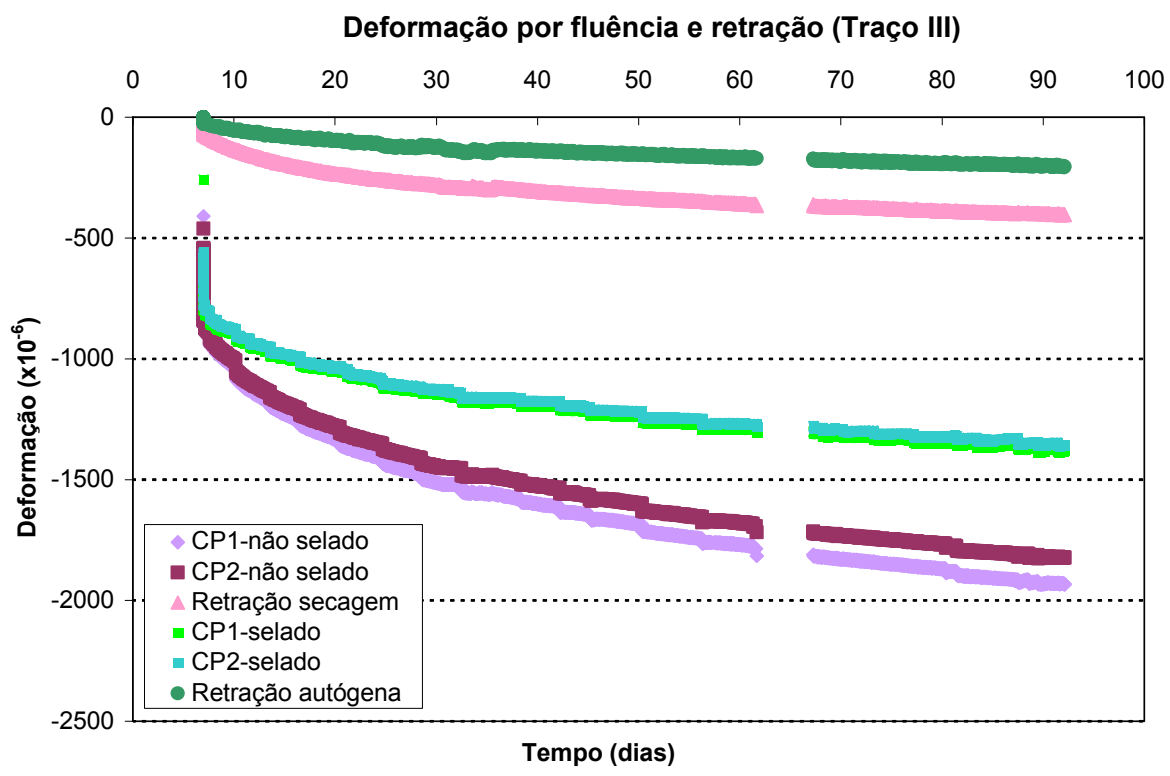

Gráfico 5.3 - Deformação por fluência e retração do concreto (Traço III).

A partir dos resultados das deformações totais, é possível determinar a deformação por secagem e a deformação básica por fluência. Para tanto, foi considerada a média das deformações ao longo do tempo dos corpos de prova A deformação de fluência por secagem $\left(\varepsilon_{c c, s}\right)$ foi obtida pela diferença da deformação dos corpos de prova não selados carregados $\left(\varepsilon_{c s}\right)$ pela deformação de retração dos corpos de prova não selados $\left(\varepsilon_{s s}\right)$ dada pela eq.(4-2). A deformação de fluência básica $\left(\varepsilon_{c c, b}\right)$ foi obtida pela diferença da deformação dos corpos de prova selados carregados $\left(\varepsilon_{c b}\right)$ pela deformação por retração autógena $\left(\varepsilon_{s a}\right)$ dada pela eq.(4-3). A parcela 
instantânea elástica $\left(\varepsilon_{i}\right)$ não foi descontada da deformação total. Nos gráficos 5.4 , 5.5 e 5.6 podem ser vistos as deformações de fluência por unidade de tensão denominada fluência específica $(\mathrm{J})$.

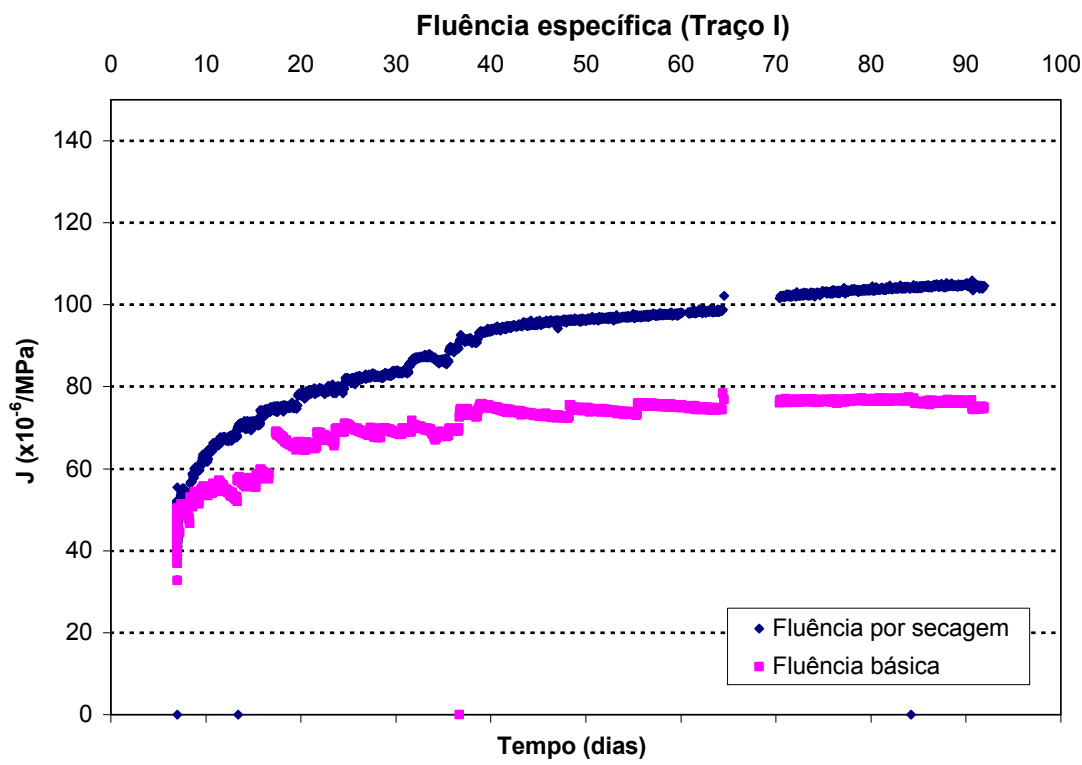

Gráfico 5.4 - Fluência por secagem e básica (Traço I).

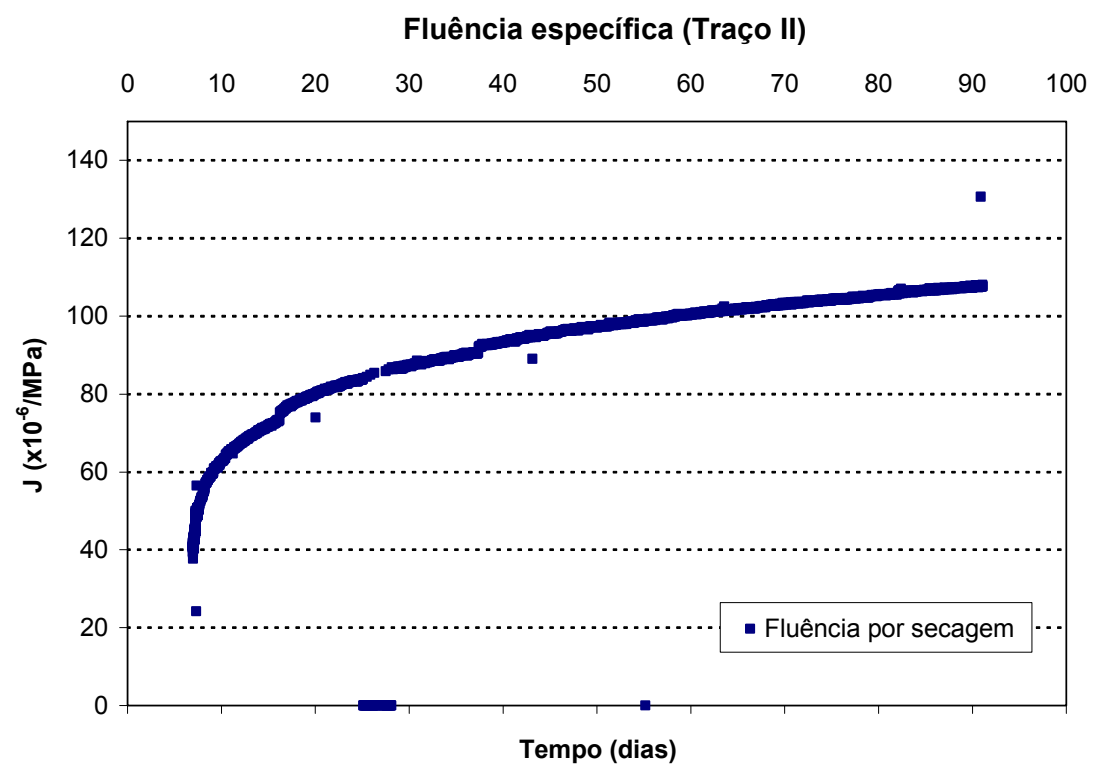

Gráfico 5.5 - Fluência por secagem e básica (Traço II). 


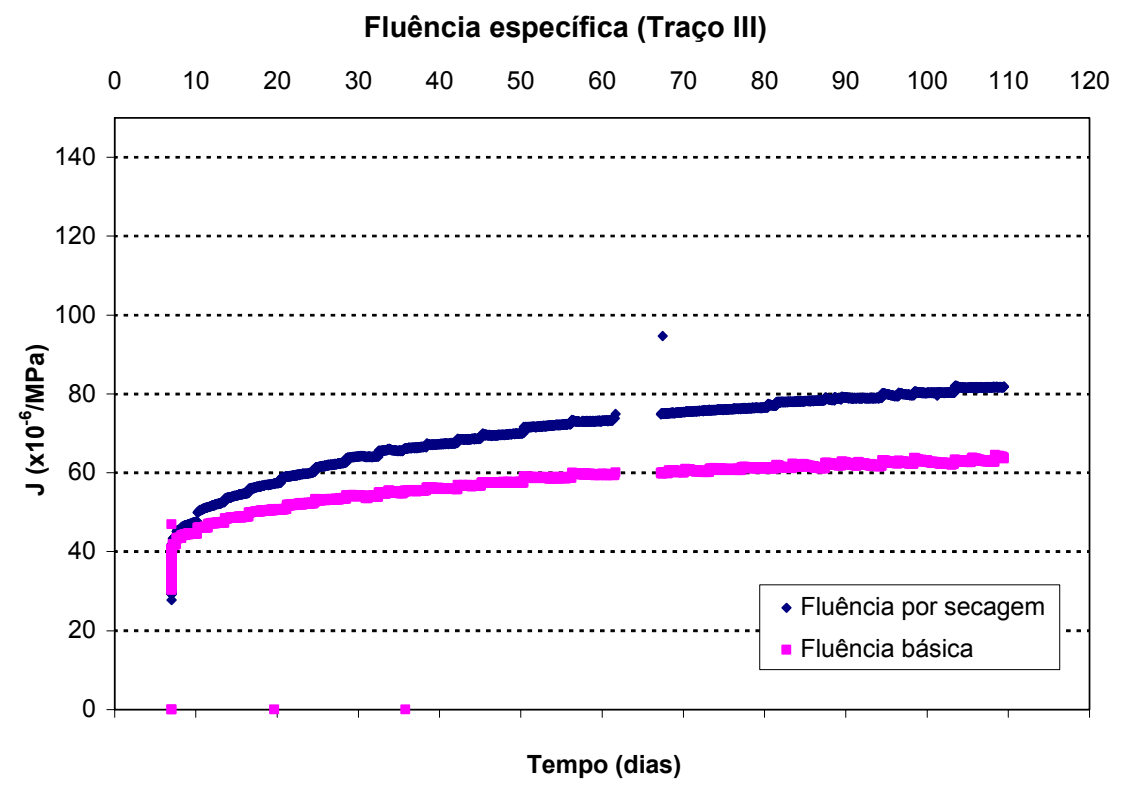

Gráfico 5.6 - Fluência por secagem e básica (Traço III).

Como pode ser visto na tabela 5.2, a resistência média à compressão e o módulo de elasticidade do concreto analisados, não tem uma taxa de crescimento considerável após os 28 dias. O mesmo ocorre com a deformação por fluência básica no concreto ao longo do tempo, tendendo a um valor assintótico. Entretanto, as deformações de fluência por secagem ainda apresentam taxa de crescimento. De acordo com Hansen e Mattock (1966) após 3 meses a taxa de crescimento das deformações por fluência é igual tanto para fluência básica como para fluência por secagem. Portanto, seria interessante a medição da fluência por um período maior de tempo a fim de verificar o aumento da taxa de crescimento das deformações da fluência por secagem.

Como já era esperado, o concreto com maior resistência média à compressão (Traço III) e, conseqüentemente, maior módulo de elasticidade apresentou deformações específicas menores, pois apresenta menor relação água cimento (MEHTA, MONTEIRO, 2008). Giovambattista e Zerbino (1993) estudaram as mesmas classes de resistência e obtiveram a mesma tendência decrescente das deformações com o aumento da resistência, embora de diferentes magnitudes das obtidas nesta pesquisa.

Esperava-se que as deformações do Traço II fossem inferiores às deformações do Traço I. Entretanto, as deformações específicas dos Traços I e II foram muito próximas, pois na moldagem do Traço II foi feito adensamento utilizando vibração 
mecânica que provavelmente induziu a formação de maiores vazios reduzindo a resistência média à compressão do concreto, como pode ser visto na tabela 5.1 .

\subsubsection{Análises dos resultados experimentais}

A dispersão dos resultados experimentais foi calculada comparando a equação logarítmica que melhor se adequou á curva experimental com os resultados obtidos experimentalmente a partir do coeficiente de variação $\omega_{B 3, a l l}$. A equação logarítmica e o coeficiente de correlação R2 estão apresentados na tabela 5.3. Os coeficientes de variação $\omega_{B 3, \text { all }}$ que representam a dispersão dos resultados experimentais estão nas tabelas 5.4 e 5.5 .

Tabela 5.3 - Equação logarítmica e R2.

\begin{tabular}{cccc}
\hline Deformação & Traço & Eq. logarítmica & R2 \\
\hline \multirow{3}{*}{ Fluência por secagem } & I & $\mathrm{y}=-117,51 \ln (\mathrm{x})-21,843^{*}$ & 0,9876 \\
& II & $\mathrm{y}=227,42 \ln (\mathrm{x})-133,34^{*}$ & 0,9743 \\
& III & $\mathrm{y}=-319,73 \ln (\mathrm{x})-58,349^{*}$ & 0,9842 \\
Fluência básica & I & $\mathrm{y}=-66,767 \ln (\mathrm{x})-108,01^{*}$ & 0,8720 \\
& III & $\mathrm{y}=190,9 \ln (\mathrm{x})-322,42^{*}$ & 0,9695 \\
\hline "y-deformação de fluência $(\mathrm{x}$ 10 & & \\
*x- tempo (dias) & & &
\end{tabular}

Utilizando a implementação no programa Matlab dos modelos de fluência analisados nesta pesquisa ( $\mathrm{ACl}, \mathrm{EC} 2, \mathrm{NBR}, \mathrm{B} 3 \mathrm{e} \mathrm{GL}$ ), é possível fazer a previsão das deformações experimentais tanto para fluência por secagem quanto para fluência básica considerando como podem ser vistos nos gráficos 5.7, 5.8, 5.9, 5.10 e 5.11. As análises foram feitas considerando fluência específica ( $\left.\times 10^{-6} / \mathrm{MPa}\right)$. 


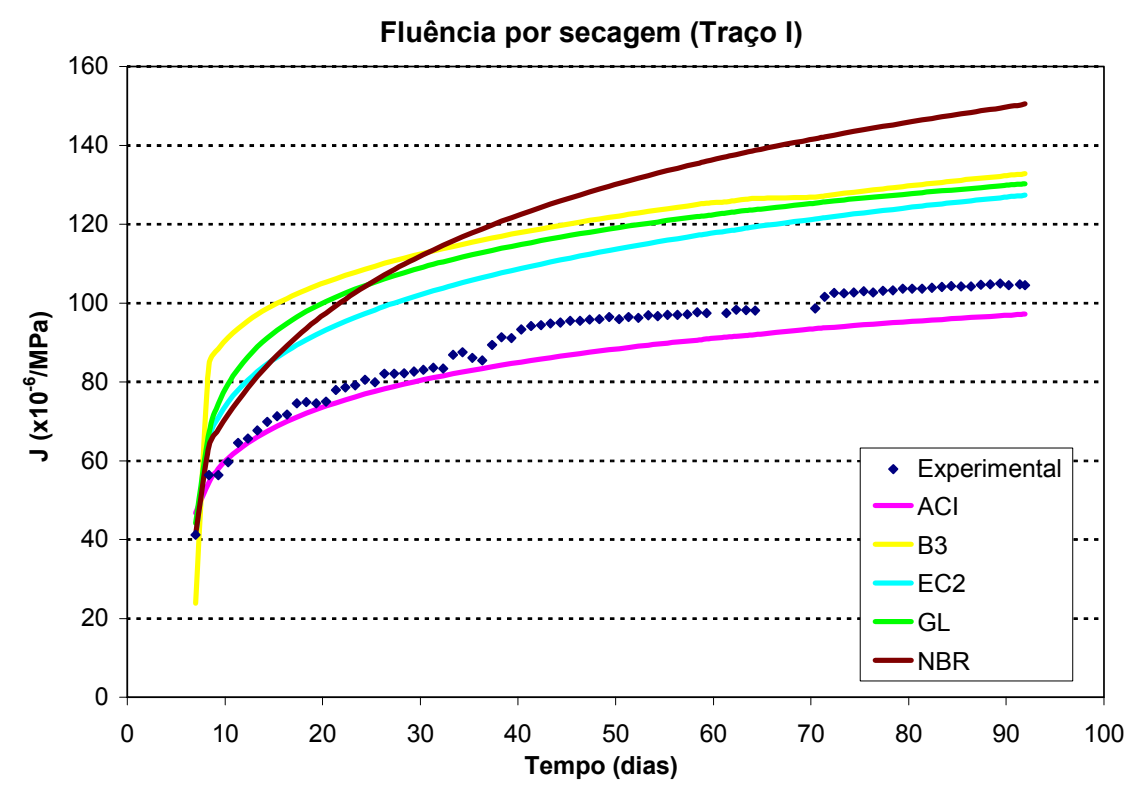

Gráfico 5.7 - Comparação dos resultados experimentais e numéricos de fluência por secagem (Traço I).

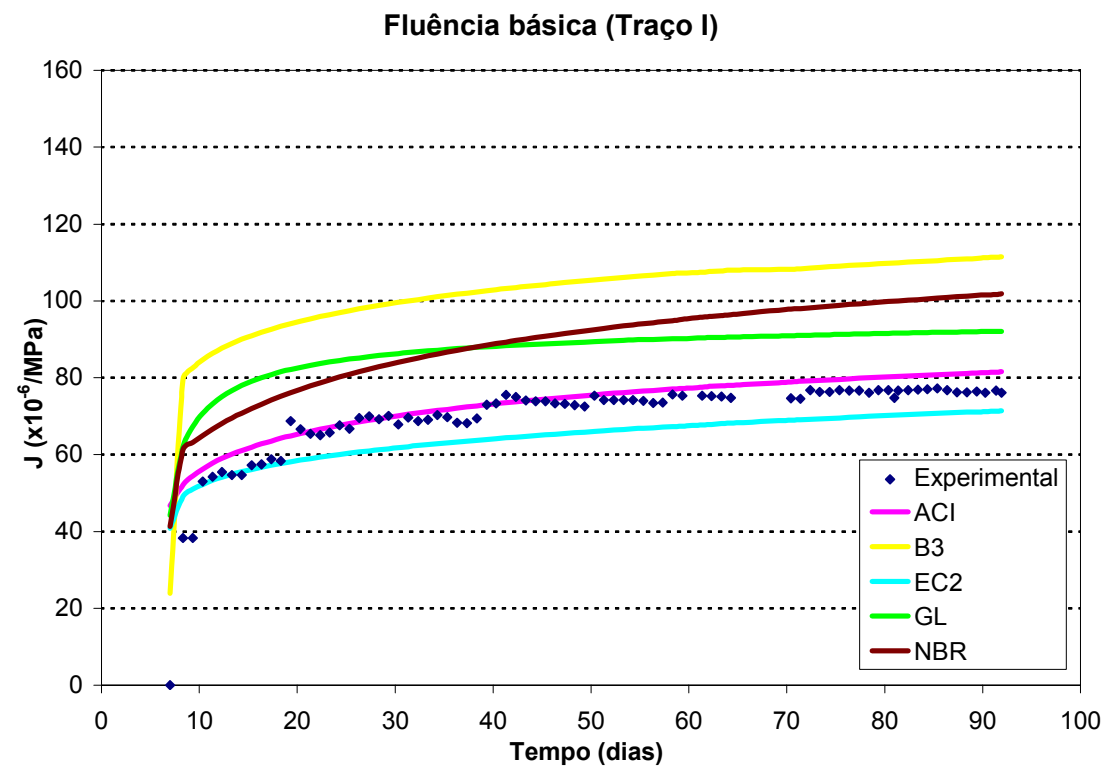

Gráfico 5.8 - Comparação dos resultados experimentais e numéricos de fluência básica (Traço I). 
Fluência por secagem (Traço II)

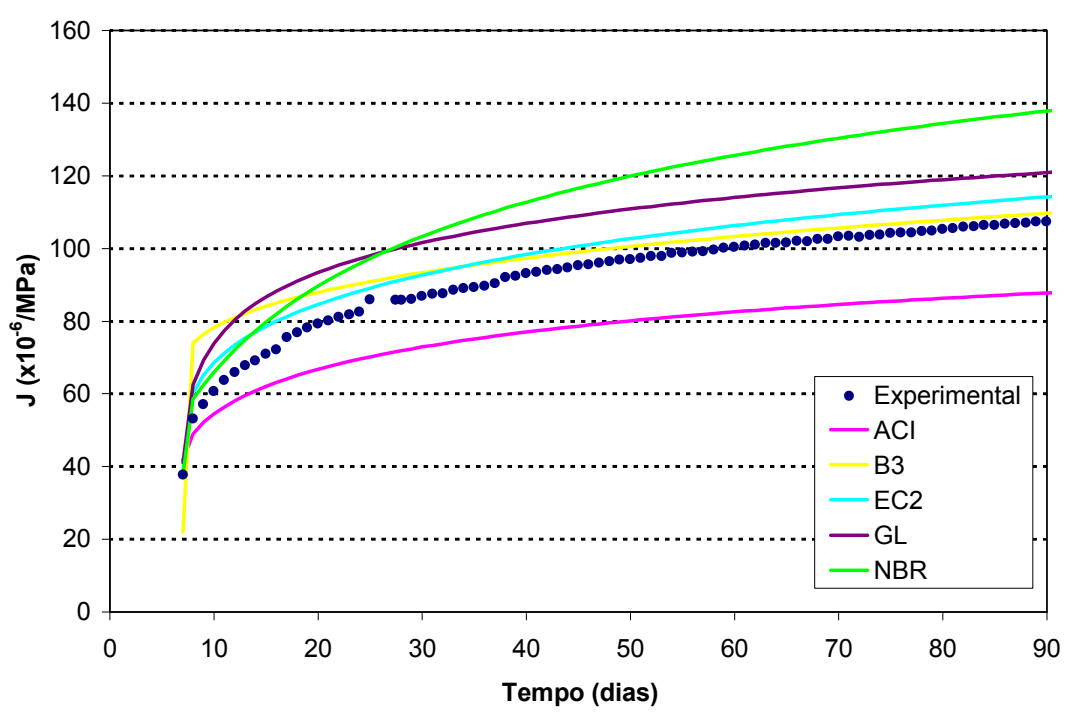

Gráfico 5.9 - Comparação dos resultados experimentais e numéricos de fluência por secagem (Traço II).

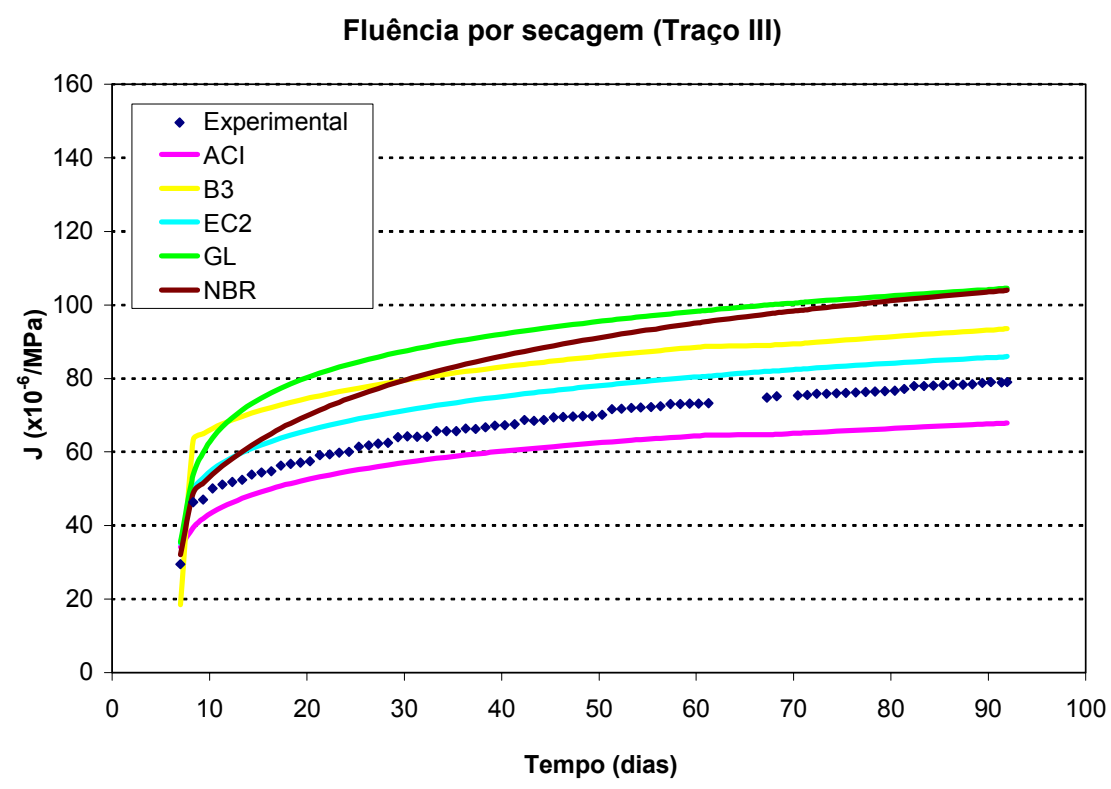

Gráfico 5.10 - Comparação dos resultados experimentais e numéricos de fluência por secagem (Traço III). 
Fluência básica (Traço III)

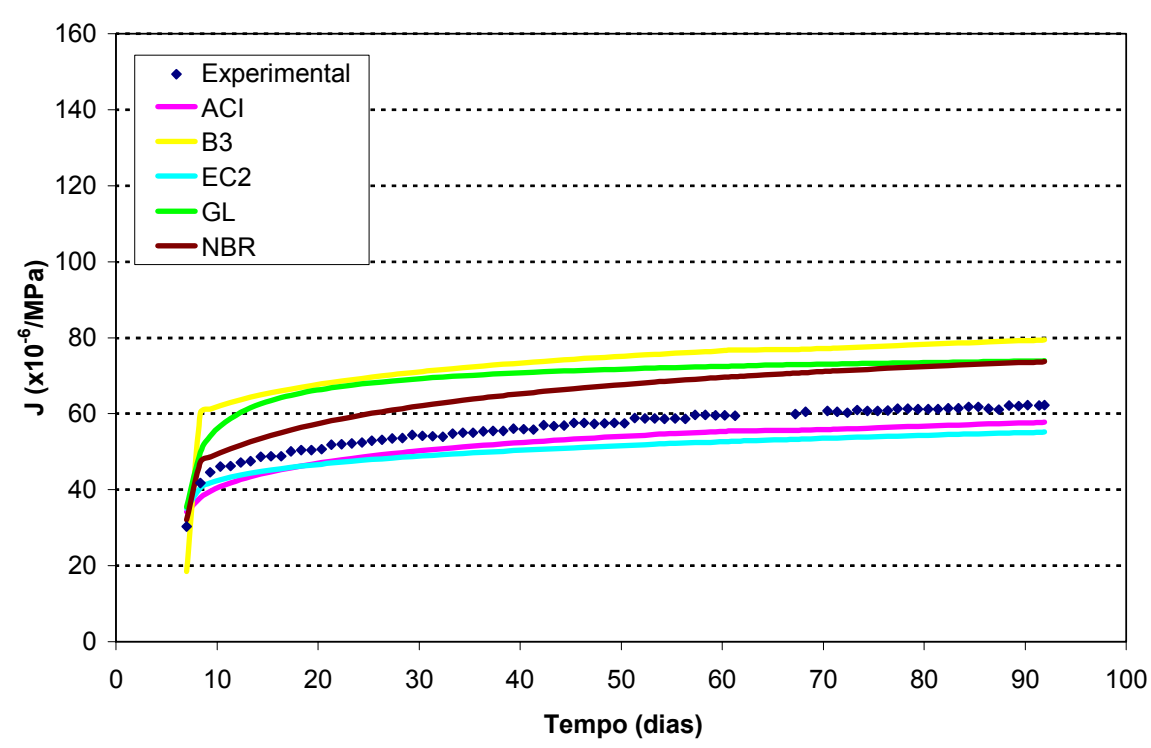

Gráfico 5.11 - Comparação dos resultados experimentais e numéricos de fluência básica (Traço III).

As tabelas 5.4 e 5.5 apresentam os coeficientes de variação B3 $\omega_{B 3}$ e os coeficientes de variação da população para todos os grupos de dados $\omega_{B 3, a l l}$, para os Traços I, II e III, tanto para fluência por secagem quanto para fluência básica.

Tabela 5.4 - Coeficientes de variação $\omega_{B 3} \mathrm{e}^{\omega_{B 3, \text { all }}}$ para fluência por secagem (\%).

\begin{tabular}{cccccccccc}
\hline Traço & Modelo & $\omega_{\mathrm{b} 3}$ & Traço & Modelo & $\omega_{\mathrm{b} 3}$ & Traço & Modelo & $\omega_{\mathrm{b} 3}$ & $\omega_{\mathrm{b} 3, \mathrm{all}}$ \\
\hline & $\mathrm{ACl}$ & 7,2 & & $\mathrm{ACl}$ & 19,1 & & $\mathrm{ACl}$ & 12,2 & 13,7 \\
& $\mathrm{~B} 3$ & 29,8 & & $\mathrm{~B} 3$ & 12,6 & & $\mathrm{~B} 3$ & 25,0 & 25,0 \\
$\mathrm{H}$ & $\mathrm{EC} 2$ & 21,4 & $\mathrm{II}$ & $\mathrm{EC} 2$ & 7,7 & $\mathrm{III}$ & $\mathrm{EC} 2$ & 10,9 & 14,6 \\
& $\mathrm{GL}$ & 26,6 & & $\mathrm{GL}$ & 16,0 & & $\mathrm{GL}$ & 34,9 & 27,0 \\
& $\mathrm{NBR}$ & 38,7 & & $\mathrm{NBR}$ & 26,9 & & $\mathrm{NBR}$ & 29,0 & 32,0 \\
& Experimental & 8,2 & & Experimental & 6,4 & & Experimental & 2,1 & 6,1 \\
\hline
\end{tabular}

Tabela 5.5 - Coeficientes de variação $\omega_{B 3} \mathrm{e}^{\omega_{B 3, \text { all }}}$ para fluência básica (\%).

\begin{tabular}{ccccccc}
\hline Traço & Modelo & $\omega_{\mathrm{b} 3}$ & Traço & Modelo & $\omega_{\mathrm{b} 3}$ & $\omega_{\mathrm{b} 3, \mathrm{all}}$ \\
\hline \multirow{4}{*}{$\mathrm{A}$} & $\mathrm{ACl}$ & 8,5 & & $\mathrm{ACl}$ & 7,9 & 8,2 \\
$\mathrm{~B} 3$ & 44,6 & & $\mathrm{~B} 3$ & 31,9 & 41,7 \\
& $\mathrm{EC} 2$ & 10,4 & & $\mathrm{EC} 2$ & 11,0 & 10,7 \\
& $\mathrm{GL}$ & 25,2 & $\mathrm{II}$ & $\mathrm{GL}$ & 23,6 & 24,4 \\
& $\mathrm{NBR}$ & 29,4 & & $\mathrm{NBR}$ & 16,9 & 24,0 \\
& Experimental & 11,8 & & Experimental & 2,0 & 8,5 \\
\hline
\end{tabular}


De acordo com Videla (2006), a magnitude e evolução da fluência diferem entre distintas regiões devido às características particulares dos materiais e os dados não podem ser diretamente comparados. Portanto, as análises desta pesquisa são feitas apenas confrontando modelos e resultados analíticos.

Em projeto, um modelo pode ser considerado preciso quando o coeficiente de variação com os resultados experimentais está em aproximadamente $20 \%$ (GARDNER; LOCKMAN 2001 e VIDELA; COVARRUBIAS; MASANA, 2004). Portanto, foram considerados eficazes os modelos que apresentaram coeficiente de variação próximo a $20 \%$.

Considerando a previsão dos modelos de fluência por secagem, ao contrário do que foi obtido por Gardner (2004) e Bažant e Baweja (2000), o modelo do ACl foi capaz de prever as deformações de fluência por secagem $\left(\omega_{\mathrm{B} 3}=13,7 \%\right)$. Além deste modelo, é possível observar que o EC2 também apresentou coeficiente de variação $14,6 \%$ aceitável. Os modelos do $G L$ e do B3 somente previram as deformações do Traço II. O B3 superestima a fluência dos Traços I e III, fato também observado por Goel; Kumar e Paul (2007).

A NBR é o único modelo que não prevê as deformações de fluência por secagem superestimando as deformações durante todo o período medido. O coeficiente de variação $\omega_{B 3, a l l}$ entre os resultados experimentais e o modelo da NBR é de $32 \%$. Uma possível explicação seria o fato deste modelo subestimar o envelhecimento do concreto. Dessa forma, o concreto estaria ganhando menos resistência ao longo do tempo e, conseqüentemente, deformando mais do que os valores reais. Além disso, SAMPAIO (2004) conclui que a NBR6118 (2004) está desatualizada, pois a caracterização da fluência no concreto é atribuída a materiais com propriedades físicas diferentes dos materiais utilizados atualmente, ou seja, não foi levada em consideração a evolução tecnológica no comportamento de tais materiais.

Para fluência básica, assim como para fluência por secagem, os modelos que são capazes de melhor prever as deformações são o $\mathrm{ACl}$ e $\circ \mathrm{EC} 2$, apresentando coeficiente de variação $\omega_{\mathrm{B} 3, \text { all }}$ de $8,2 \%$ e $10,7 \%$, respectivamente. O modelo do $\mathrm{GL}$ não prevê as deformações de fluência básica para os Traços I e III, apresentando coeficiente de variação $\omega_{\mathrm{B} 3 \text {,all }}$ de $24,4 \%$. Assim como para fluência por secagem, as deformações de fluência básica previstas pela NBR para o Traço I superestimam 
exageradamente os resultados experimentais, apesar deste modelo ser capaz de prever as deformações do traço de maior resistência. Ao contrário do que foi obtido por Gardner (2004) e Bažant e Baweja (2000), o modelo do B3 é o único que não prevê as deformações de fluência básica tanto para o Traço I quanto para o Traço III superestimando exageradamente as deformações.

Provavelmente o modelo do EC2 foi eficiente para previsão tanto da fluência por secagem quanto da fluência básica, pois, como foi avaliado no capítulo 3 , é o modelo que tem maior influência da variação da resistência à compressão, representando melhor o comportamento dos concretos estudados.

Além das possíveis explicações supracitadas justificando as diferenças das deformações entre os modelos teóricos e os resultados experimentais, há o fato dos modelos desenvolvidos em outros países serem derivados de resultados relativos ao tipo de cimento e materiais proveniente de cada região (MACHADO et al., 2008). Isto dificulta a boa correlação destes modelos e os resultados de fluência provenientes de concretos brasileiros.

\subsection{Retração em corpos de prova}

Neste item são apresentados os resultados experimentais de retração por secagem dos corpos de prova e são feitas análises considerando modelos de previsão.

\subsubsection{Resultados experimentais}

Os resultados dos Traços I, III e IV de retração por secagem estão apresentados nos gráficos $5.13,5.15$, e 5.17. As perdas de massa ao longo do tempo estão apresentadas nos gráficos 5.12, 5.14 e 5.16. Para análise dos resultados experimentais de deformação por secagem foi considerada a média das deformações no período medido. Alguns corpos de prova apresentaram problemas no pino de medição, impossibilitando as leituras de deformação. Portanto, são 
apresentados os resultados experimentais dos corpos de prova que não tiveram problemas de medição devido ao pino.

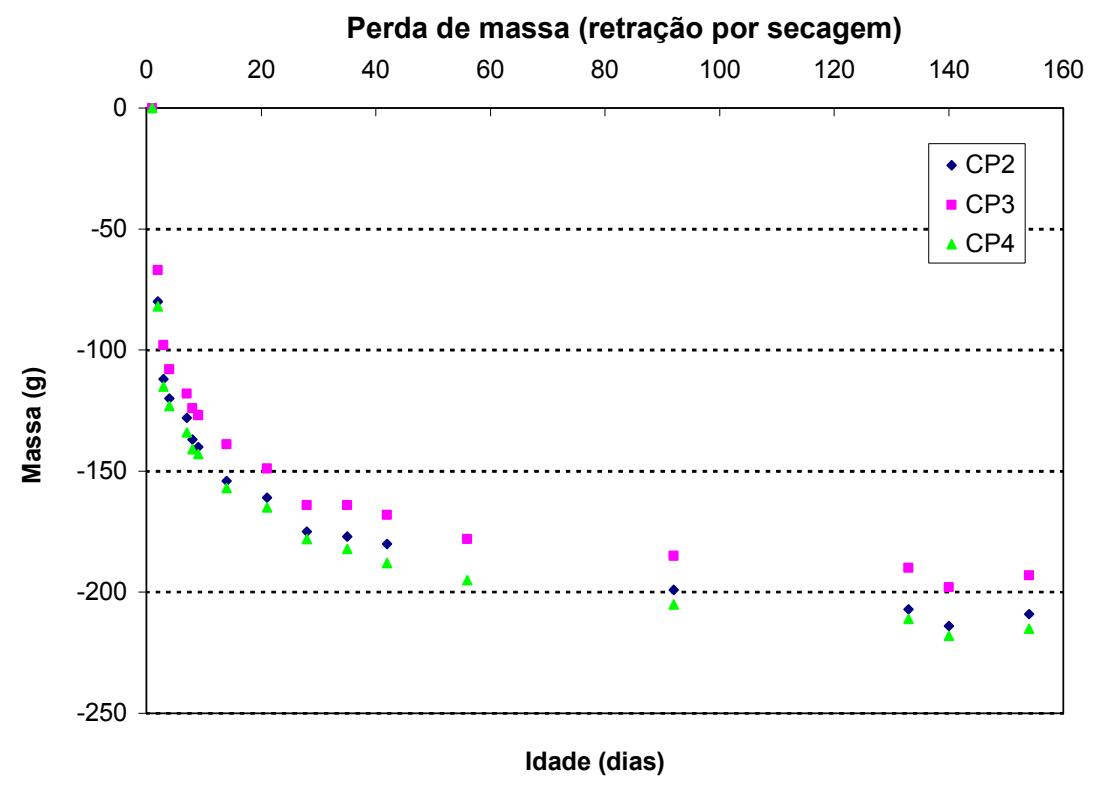

Gráfico 5.12 - Perda de massa em corpos de prova de retração por secagem (Traço I).

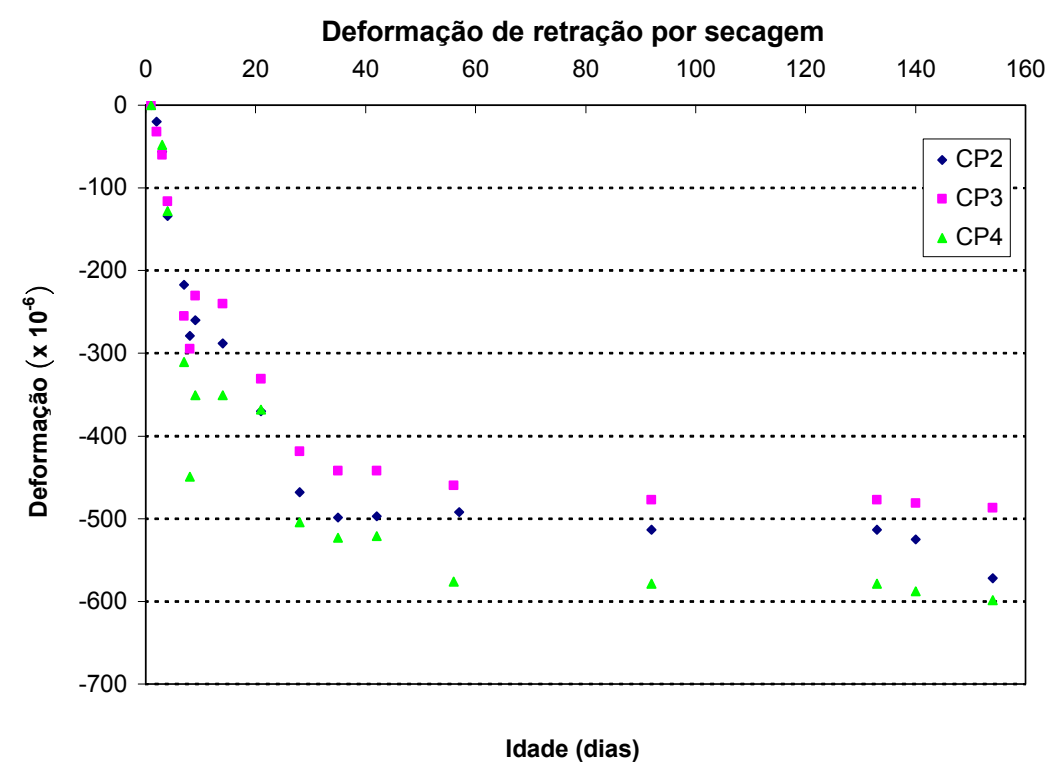

Gráfico 5.13 - Deformação de retração por secagem (Traço I). 


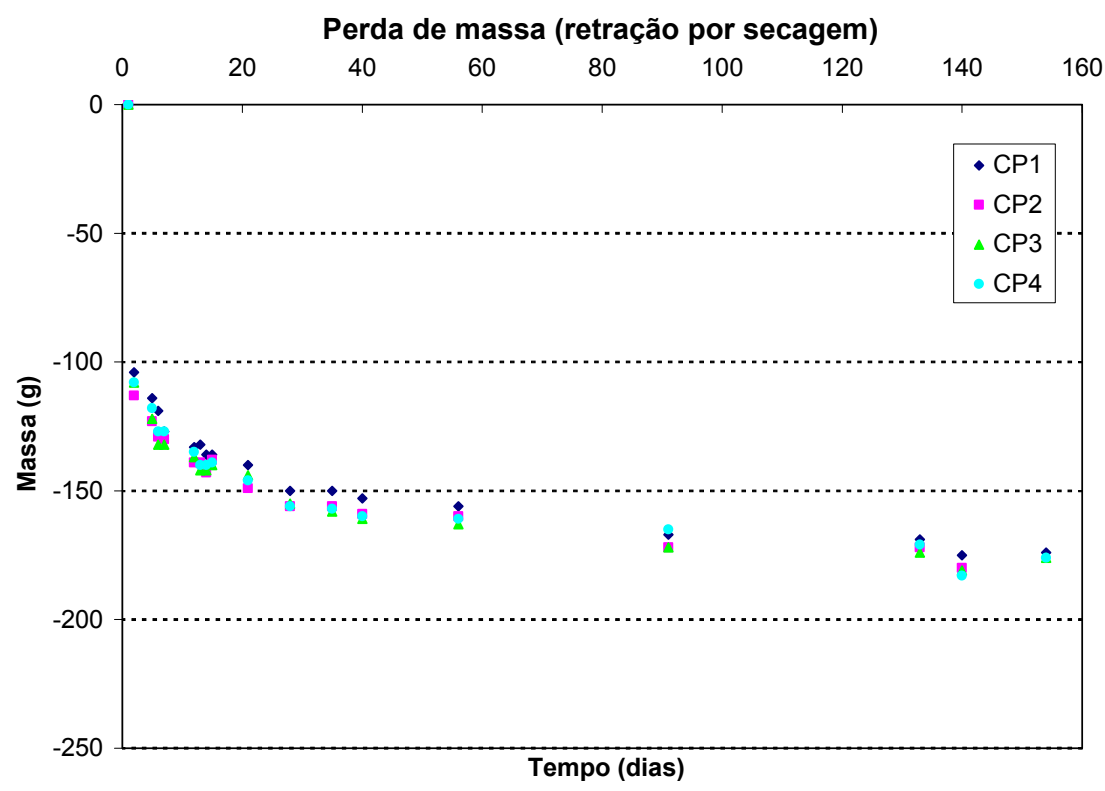

Gráfico 5.14 - Perda de massa em corpos de prova de retração por secagem (Traço III).

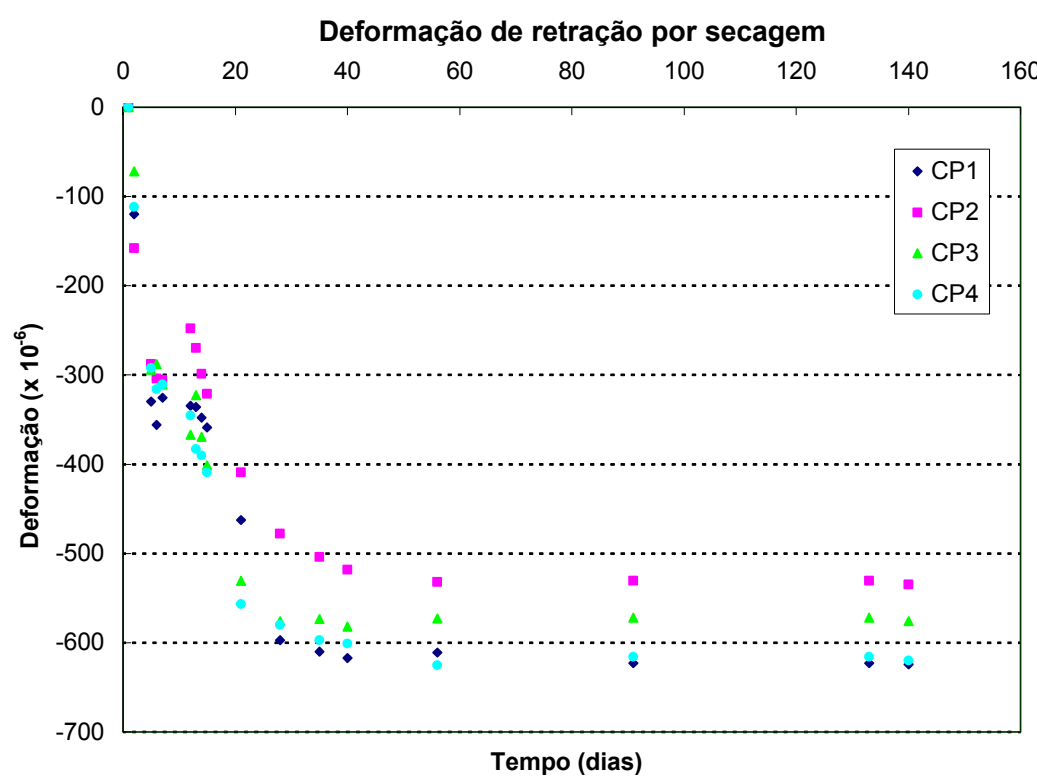

Gráfico 5.15 - Deformação de retração por secagem (Traço III). 


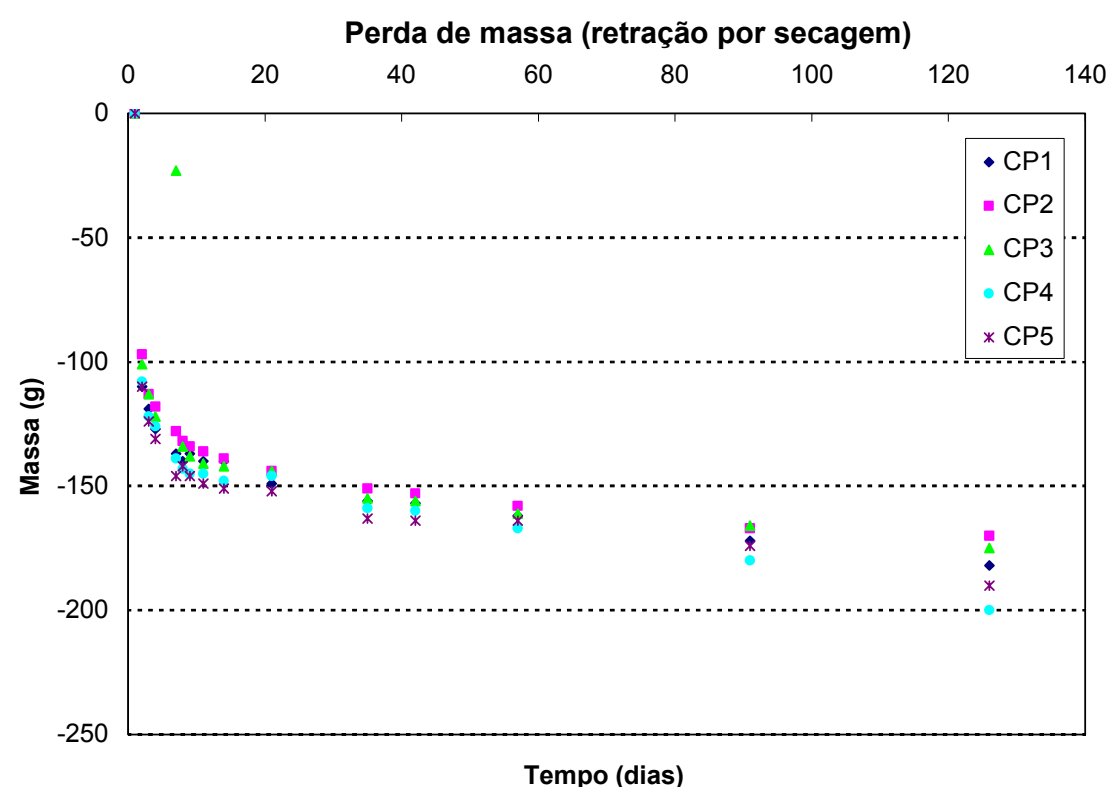

Gráfico 5.16 - Perda de massa em corpos de prova de retração por secagem (Traço IV).

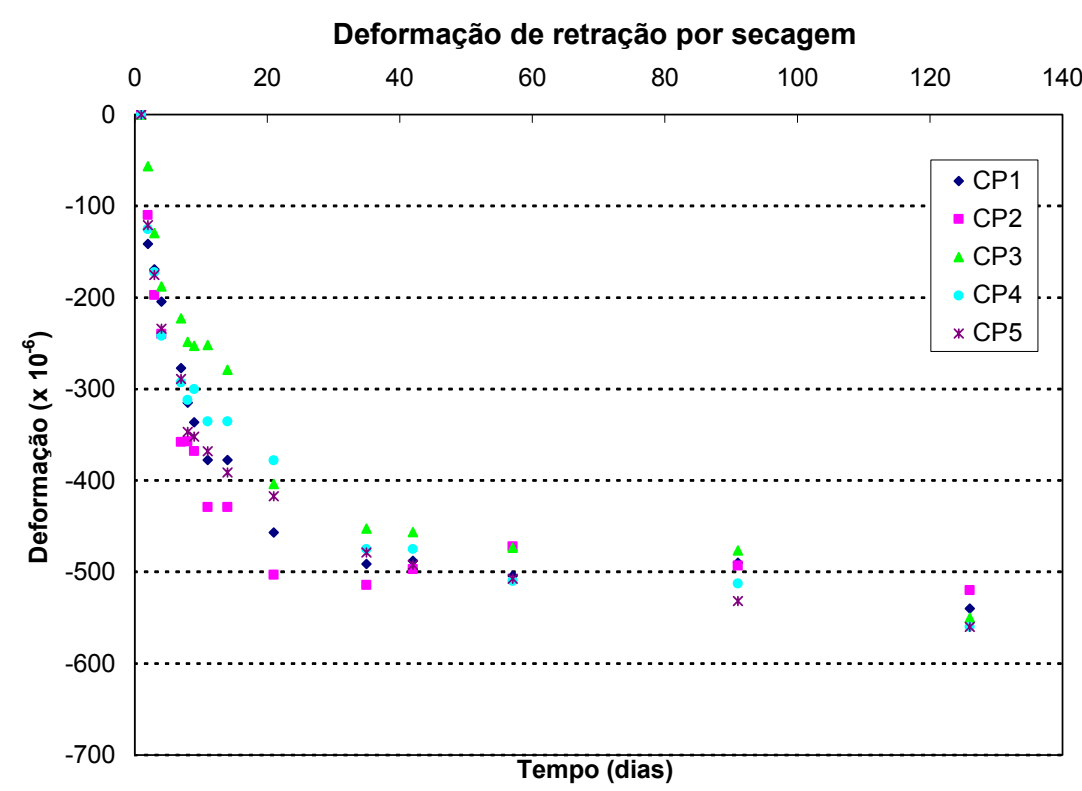

Gráfico 5.17 - Deformação de retração por secagem (Traço IV).

A partir dos gráficos é possível notar que, ao contrário do que se esperava (MEHTA; MONTEIRO, 2008 e TAZAWA; MIYAZAWA, 1993), as deformações por retração dos concretos de Traço I, III e IV analisados são muito próximas. Entretanto, de acordo com Neville (1997), em concretos com mesma trabalhabilidade, ou seja, mesmo teor de água, a retração não é alterada pelo aumento do teor de cimento. O mesmo resultado foi observado por Kalintzis (2000). Além disso, é possível notar que após 91 dias as deformações parecem ter estabilizado, demonstrando taxa de crescimento das deformações muito baixas. 
Considerando os traços analisados, o período de 91 dias pode ser considerado como suficiente para medição da retração por secagem.

\subsubsection{Análises dos resultados experimentais}

Assim como para fluência, foram calculados os valores da dispersão dos resultados experimentais comparando a curva logarítmica que melhor se ajustou (tabela 5.6) com os resultados obtidos experimentalmente por meio do coeficiente de variação $\omega_{B 3, a l l}$ (tabela 5.8). Wittmann et al. (1987) concluiu que o coeficiente de variação dos resultados experimentais de retração decresce com o tempo atingindo 9\%. Bažant et al. (1987) verificou que, para comparar modelos com os resultados experimentais de uma única betonada, devem ser considerados coeficientes de variação de $10 \%$ até 7 dias e $7 \%$ até 1100 dias. Nesta pesquisa, foi adotado como adequado um coeficiente de variação dos resultados experimentais de aproximadamente $10 \%$.

Tabela 5.6 - Equação logarítmica e R2.

\begin{tabular}{ccc}
\hline Traço & Eq. logarítmica & R2 \\
\hline I & $\mathrm{y}=121,7 \ln (\mathrm{x})+56,12^{*}$ & 0,9249 \\
III & $\mathrm{y}=91,964 \ln (\mathrm{x})+162,34^{*}$ & 0,8326 \\
IV & $\mathrm{y}=91,694 \ln (\mathrm{x})+138,47^{*}$ & 0,9431 \\
* $\begin{array}{l}\mathrm{y} \text { - deformação de retração por secagem }\left(\mathrm{x}_{10^{-6}}\right) \\
\mathrm{x} \text { - tempo (dias) }\end{array}$ &
\end{tabular}

De acordo com Videla (2006), a magnitude e a evolução da retração diferem entre países e os resultados não podem ser diretamente comparados. Entretanto, com o objetivo de analisar o comportamento de concretos de diversas classes (Traços I, III e IV) foram coletados resultados experimentais a partir do RILEM data bank com características semelhantes aos traços estudados nesta pesquisa. As características consideradas para seleção dos resultados experimentais coletados do RILEM data bank estão apresentadas na tabela 5.7 . 
Tabela 5.7 - Características dos concretos selecionados do RILEM data bank.

\begin{tabular}{cccc}
\hline \multirow{2}{*}{ Característica } & \multicolumn{3}{c}{ Traço } \\
\cline { 2 - 4 } & RD1 & RD2 & RD3 \\
\hline Fonte & Stockl, S. & Kommendant, G. J.; & Summer, T. H.; \\
Tipo de cimento & $(1981)$ & Polivka, M; Pirtz, D. (1976) & Schrage I. (1993) \\
Consumo de cimento & 250 & Slow & Slow \\
$\left(\mathrm{kg} / \mathrm{m}^{3}\right)$ & $410-420$ & $450-470$ \\
$\mathrm{a} / \mathrm{c}$ & 0,8 & $0,3-0,4$ & \\
Temperatura $\left({ }^{\circ} \mathrm{C}\right)$ & ---- & 20 a 25 & $0,3-0,4$ \\
Umidade Relativa(\%) & ---- & 50 & 20 a 25 \\
\hline
\end{tabular}

Os resultados do RILEM data bank até aproximadamente 170 dias e os resultados experimentais de retração por secagem até 154 dias correspondente às classes de concreto analisadas estão apresentados no gráfico 5.18. Como pode ser visto no gráfico 5.18, é possível notar que os resultados experimentais de retração de concretos com diferentes classes são muito próximos, tanto para os resultados analisados nesta pesquisa quanto para os resultados coletados do RILEM data bank. Entretanto, como já era esperado, não há equivalência entre os resultados de mesma classe medidos e provenientes do RILEM data bank, pois apesar das características dos traços comparados serem semelhantes, os materiais analisados são provenientes de diferentes regiões resultando nesta dispersão (VIDELA, 2006).

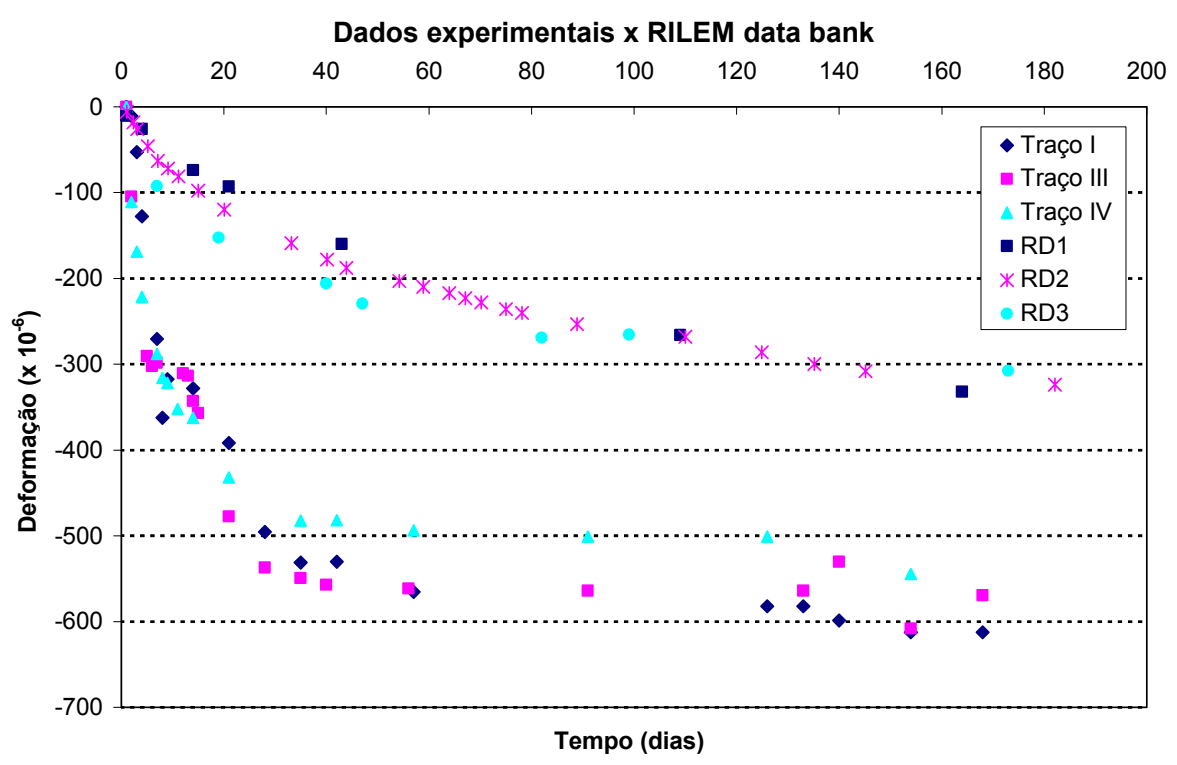

Gráfico 5.18 - Resultados experimentais e do RILEM data bank. 
Os resultados experimentais medidos até 154 dias e as previsões dos modelos até 200 dias para os Traços I, II e III estão apresentados nos gráficos 5.19, 5.20 e 5.21. A tabela 5.8 apresenta o coeficiente de variação B3 $\omega_{B 3}$ e o coeficiente de variação da população para todos os grupos de dados $\omega_{B 3, a l l}$, para os Traços I, III e IV.

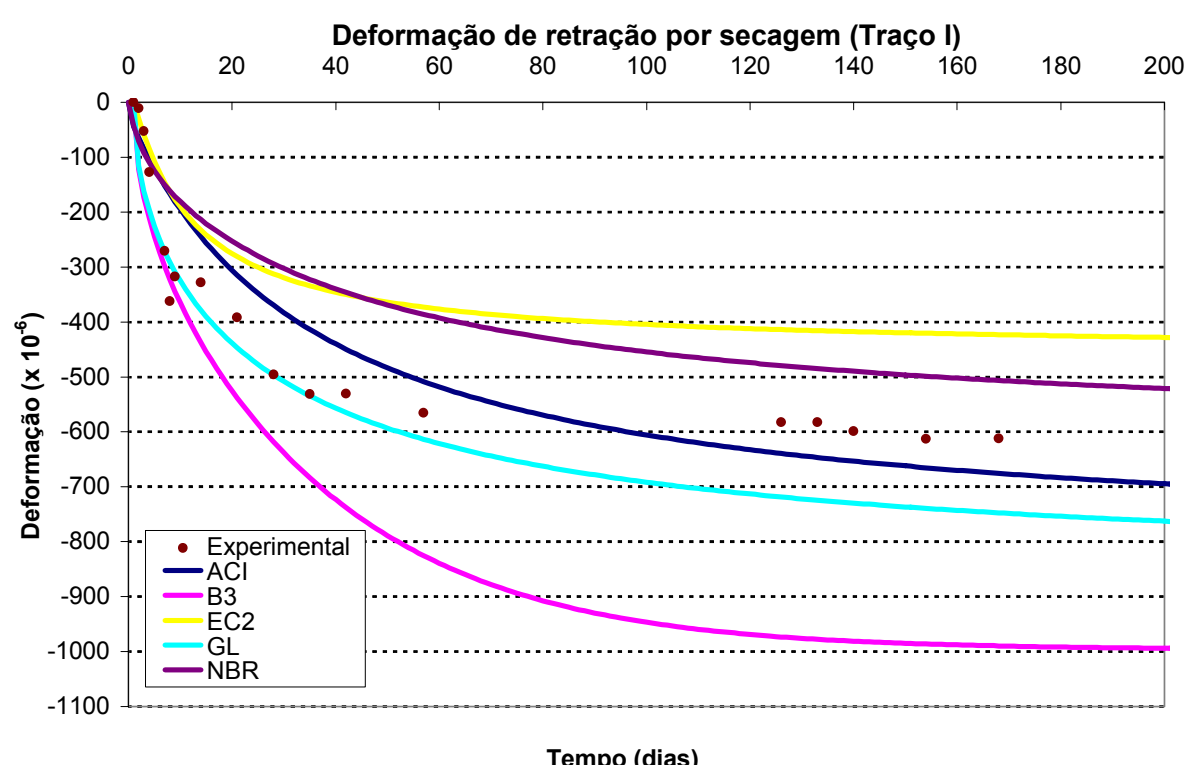

Gráfico 5.19 - Resultados experimentais e teóricos (Traço I).

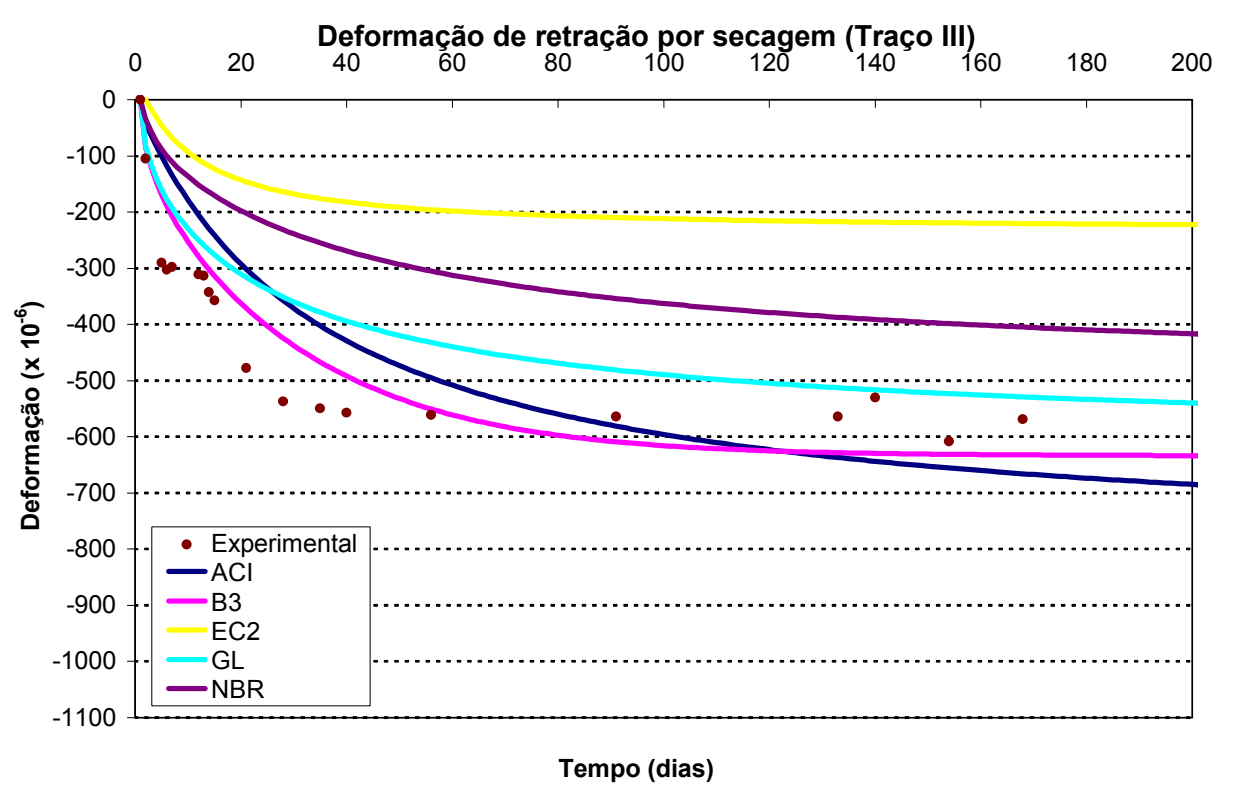

Gráfico 5.20 - Resultados experimentais e teóricos (Traço III). 


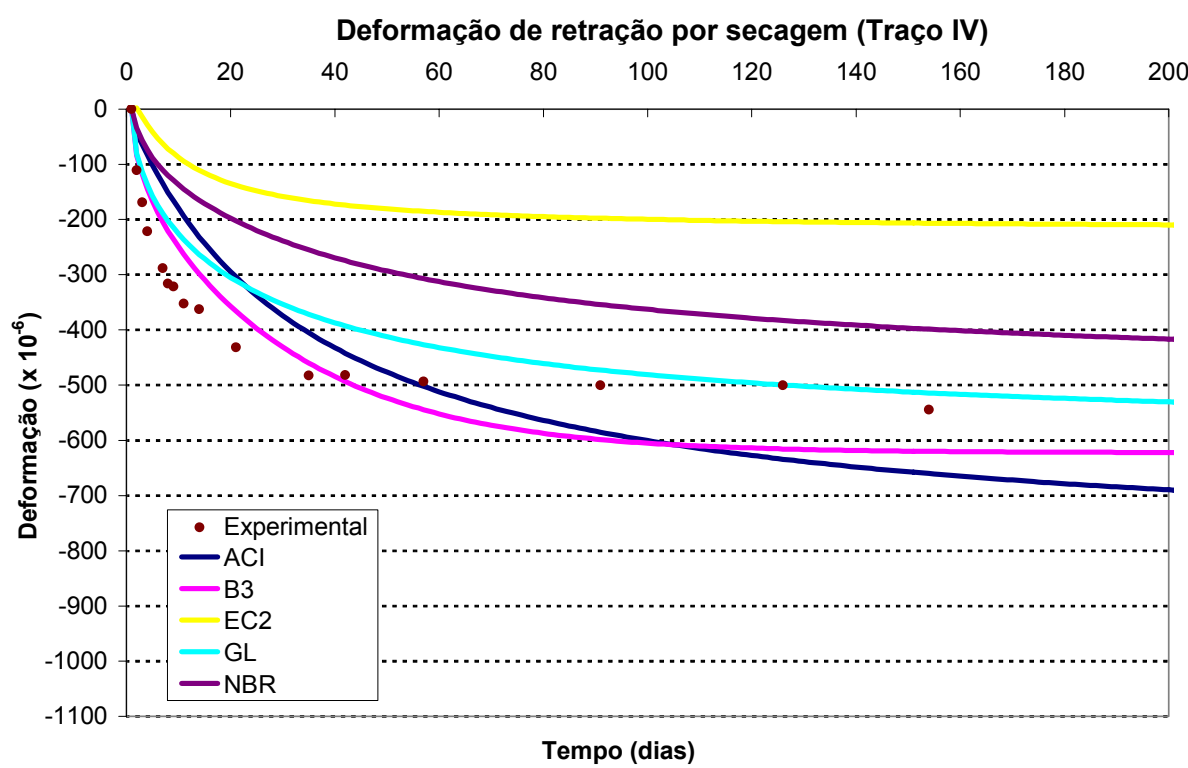

Gráfico 5.21 - Resultados experimentais e teóricos (Traço IV).

Tabela 5.8 - Coeficientes de variação $\omega_{B 3}$ e $\omega_{B 3, \text { all }}$ (\%).

\begin{tabular}{ccccc}
\hline \multirow{3}{*}{ Modelo } & \multicolumn{3}{c}{$\omega_{B 3}(\%)$} & \multirow{2}{*}{$\omega_{\text {B3,all }}(\%)$} \\
\cline { 2 - 4 } & \multicolumn{3}{c}{ Traço } \\
\cline { 2 - 4 } & I & III & IV \\
\hline ACl & 23,3 & 28,1 & 29,0 & 26,9 \\
B3 & 68,4 & 17,3 & 20,7 & 42,5 \\
EC2 & 45,5 & 86,0 & 90,0 & 76,5 \\
GL & 21,2 & 29,4 & 28,5 & 26,6 \\
NBR & 40,4 & 57,0 & 59,0 & 52,8 \\
Experimental & 11,8 & 14,2 & 10,5 & 12,3 \\
\hline
\end{tabular}

De acordo com Gardner (2001) e Videla; Covarrubias; Masana (2004), um modelo é considerado capaz de prever as deformações de retração quando o coeficiente de variação é de aproximadamente $20 \%$. Apesar de Bažant (2001) afirmar que o coeficiente de variação adequado seja de $34 \%$. Portanto, é adotado nesta pesquisa um coeficiente de variação eficaz para previsão da retração de aproximadamente $25 \%$.

Os únicos modelos de previsão que não consideram a variação das deformações ao longo do tempo com as classes de resistências são a NBR e o $\mathrm{ACl}$. Portanto teoricamente ambos deveriam ser capazes de representar as curvas experimentais. Ao contrário do que foi obtido por Bažant e Baweja (2000), Gardner (2004), Videla (2006), Goel; Kumar e Paul (2007), o modelo do ACl é um dos 
modelos que melhor prevê as deformações experimentais medidas no período estudado, pois, analisando os três traços (Traço I, Traço III e Traço IV) é o que apresenta o menor coeficiente de variação (26,9\%). Miller (2008) também concluiu que o $\mathrm{ACl}$ é o modelo que melhor prevê os resultados de retração por secagem. Entretanto, a NBR, apesar de ser o modelo utilizado para previsão das deformações dos concretos brasileiros, subestima os resultados experimentais com um coeficiente de variação total de $52,8 \%$ para os três traços.

Surpreendentemente, apesar do modelo do GL considerar poucos dados de entrada e levar em conta como parâmetro a resistência à compressão, ele é capaz de prever as deformações experimentais. De acordo com Al-Manasseer e Lam (2005), o GL é capaz de prever as deformações, pois este modelo foi elaborado a partir dos resultados do RILEM data bank. Apesar de não haver resultados brasileiros no RILEM data bank, neste banco de dados foi considerado um vasto grupo de resultados experimentais para elaboração deste modelo e, provavelmente, existam concretos com características semelhantes aos estudados nesta pesquisa.

Como já era esperado, os modelos do EC2 e o B3 não são capazes de prever as deformações de retração por secagem, uma vez que consideram em sua formulação o parâmetro de resistência à compressão alterando as curvas de deformação para cada resistência analisada. O modelo do EC2 subestimou exageradamente as deformações por retração apresentando um coeficiente de variação total de 76,5\%. Analisando somente o Traço III e Traço IV, o modelo B3 é capaz de prever as deformações experimentais apresentando coeficiente de variação baixo de $17,3 \%$ e $20,7 \%$, respectivamente. Entretanto, houve muita variação $(68,4 \%)$ para o Traço IV. Isso se deve ao fato da resistência à compressão afetar consideravelmente os resultados, fato não verificado a partir dos resultados experimentais tanto medidos quanto provenientes do RILEM data bank. 


\subsection{Protótipos de pilares}

Neste item são apresentados e analisados os resultados experimentais de deformação de fluência e retração do concreto e da carga transferida para as armaduras monitoradas dos protótipos de pilares.

\subsubsection{Resultados experimentais}

Analisando o comportamento geral dos protótipos, é possível notar que não foram detectadas fissuras nos pilares analisados. Além disso, apesar dos cuidados tomados para centralização da carga, foi verificada flexão indesejada nos protótipos, com maior intensidade nos pilares com taxa de armadura de 2,8\%. De acordo com Ramos (2001) e Oliveira (2004), este fato é comum quando se tenta obter compressão simples, visto que há outros fatores como a heterogeneidade do concreto que acabam por dificultar a aplicação do carregamento de forma perfeitamente centrada. Portanto, para análise dos resultados das deformações das armaduras são considerados os valores médios.

\subsubsection{1. $F 40-2,8-1$}

Todos os sensores deste protótipo funcionaram perfeitamente, não havendo perda dos resultados experimentais.

Nos gráficos 5.22 e 5.23 são apresentadas as deformações das armaduras e do concreto ao longo de 91 dias, respectivamente. Houve diferença de deformação ao longo do tempo entre as armaduras sendo que a diferença máxima observada aos 91 dias foi de aproximadamente $224 \times 10^{-6}$. Em média, aos 91 dias as deformações nas armaduras foram de $1148 \times 10^{-6}$. 
A deformação no concreto aos 91 dias foi de $1072 \times 10^{-6}$, ou seja, o concreto apresentou deformação superior às armaduras.

F 40-2,8-1

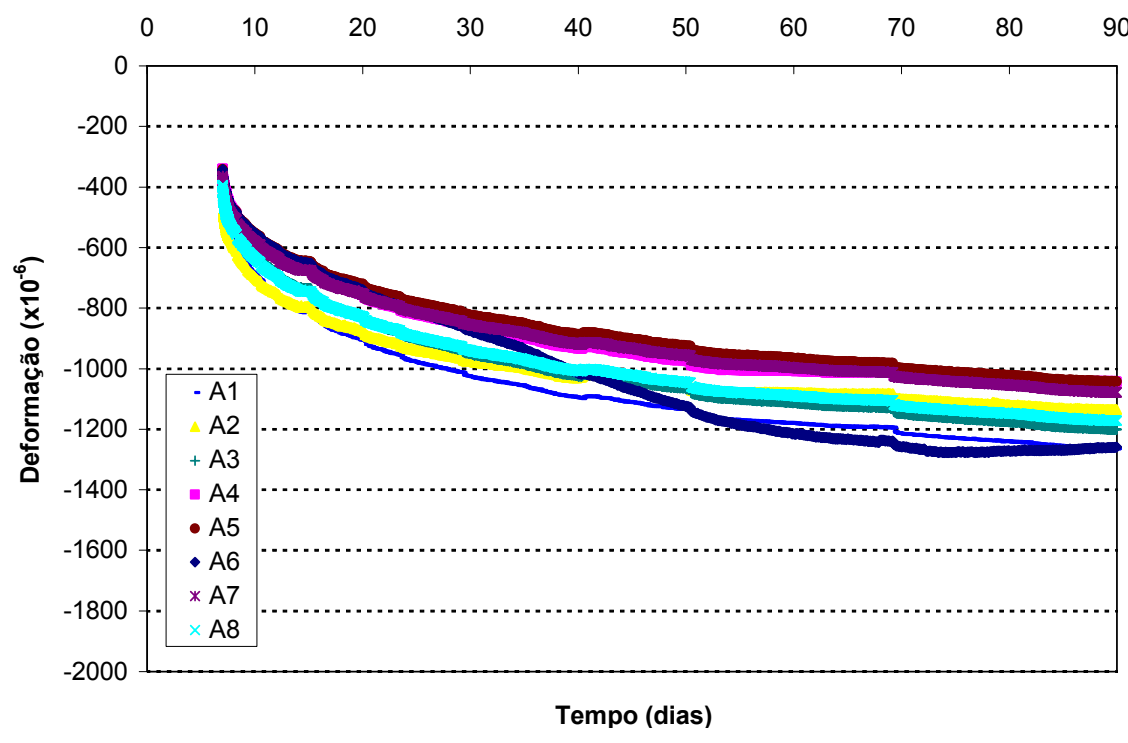

Gráfico 5.22 - Deformação nas armaduras do pilar F40-2,8-1.

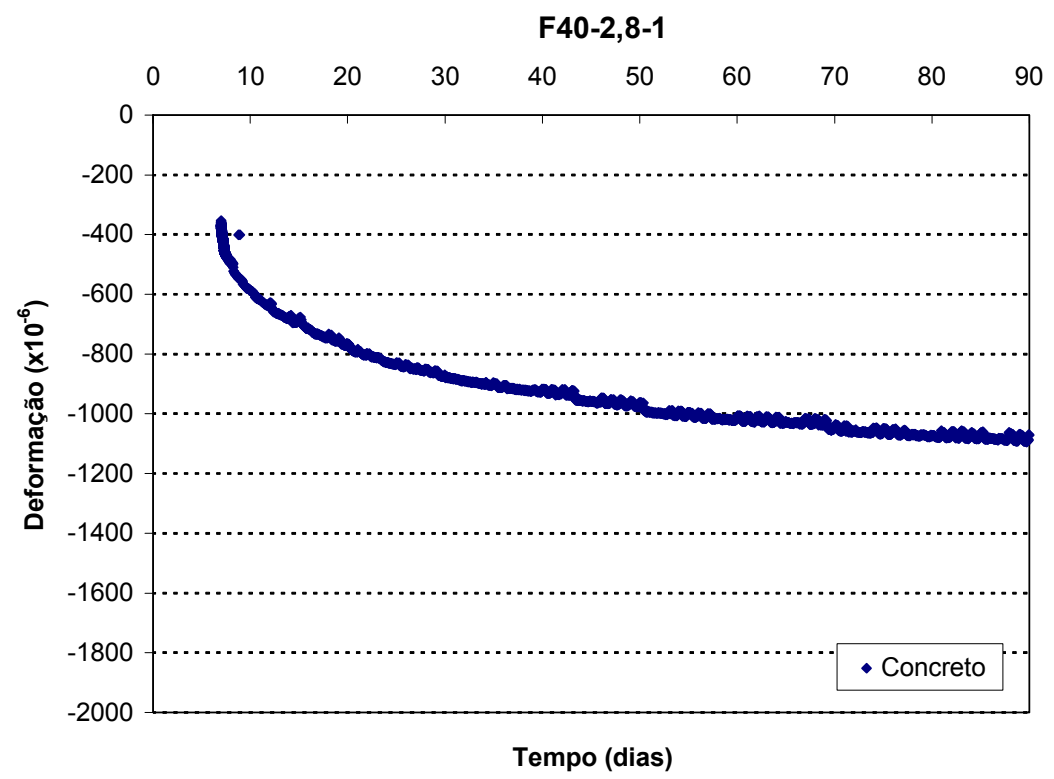

Gráfico 5.23 - Deformação no concreto do pilar F40-2,8-1. 
Ocorreu erro nas leituras dos sensores da posição 5 ao fim do dia do carregamento acarretando em acúmulo de erro nas deformações para as idades avançadas. Os sensores na posição 4 funcionaram até 41 dias. Acredita-se que tanto para os sensores da posição 4 quanto da posição 5, o sinal do sensor deve ter sido afetado pela umidade.

Este protótipo apresentou diferenças entre as deformações nas armaduras atingindo diferença máxima de $350 \times 10^{-6}$, como pode ser visto no gráfico 5.24. Para 91 dias as deformações da armadura foram em média $1125 \times 10^{-6}$.

Como já era esperado, a deformação do concreto (gráfico 5.25) deste protótipo foi próximo $\left(1027 \times 10^{-6}\right)$ ao do protótipo F40-2,8-1.

F40-2,8-2

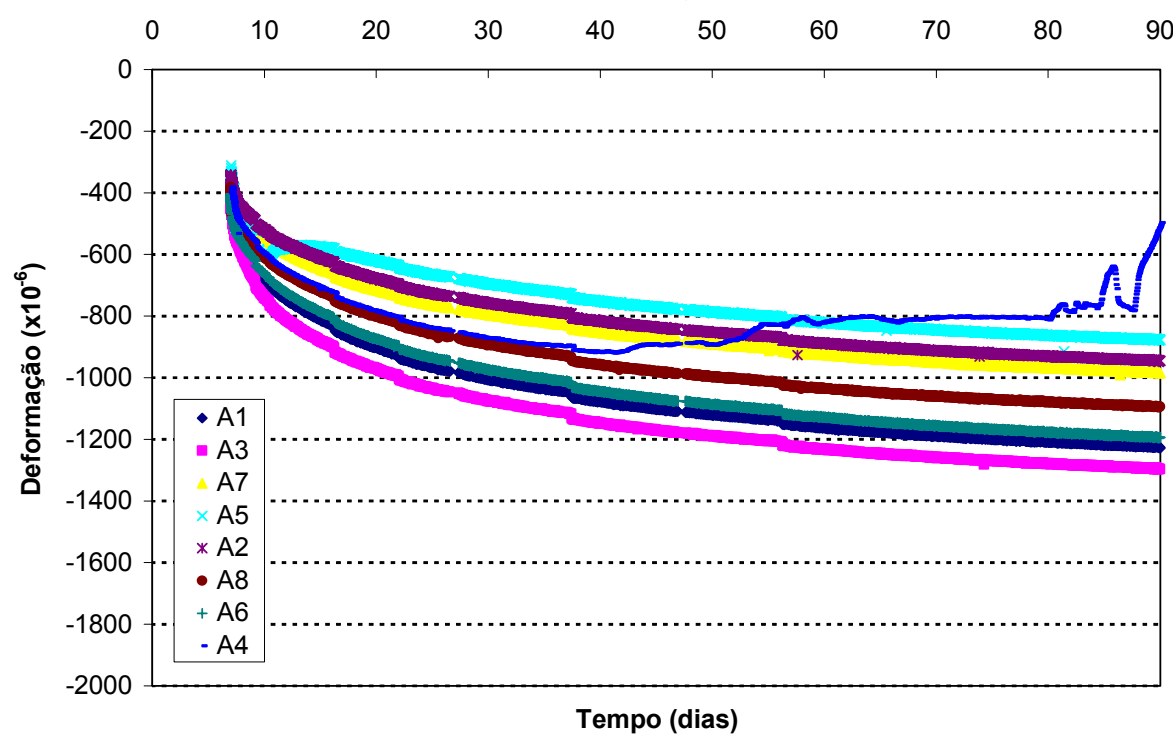

Gráfico 5.24 - Deformação nas armaduras do pilar F40-2,8-2. 


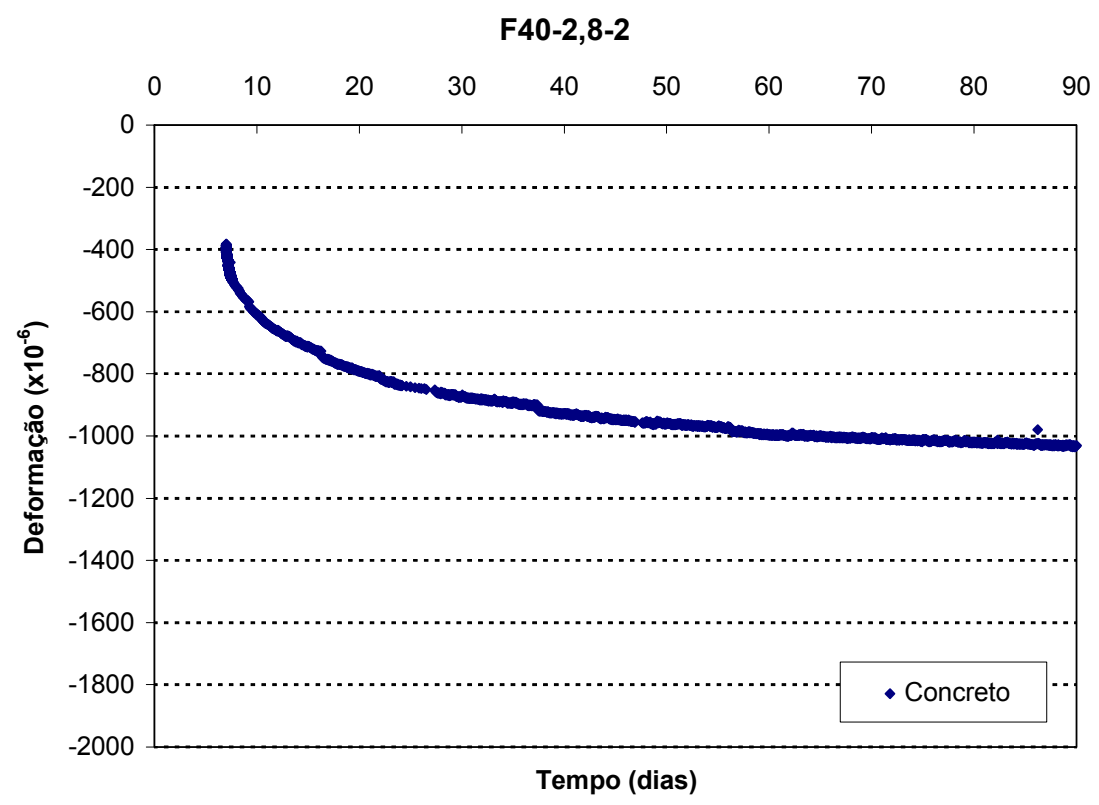

Gráfico 5.25 - Deformação no concreto do pilar F40-2,8-2.

\subsubsection{3. $\mathrm{F} 30-2,8-1$}

Todos os sensores funcionaram perfeitamente não havendo perda dos resultados. Como era esperado, a média das deformações nas armaduras deste protótipo são inferiores à do protótipo F40-2,8-1 devido à tensão de carregamento ser menor. Aos 91 dias, em média a deformação das armaduras foi de $895 \times 10^{-6}$. A deformação do concreto, como pode ser visto no gráfico 5.27 , também é inferior ao do pilar carregado com $40 \%$ da resistência média à compressão desta idade $\left(885 \times 10^{-6}\right)$. 


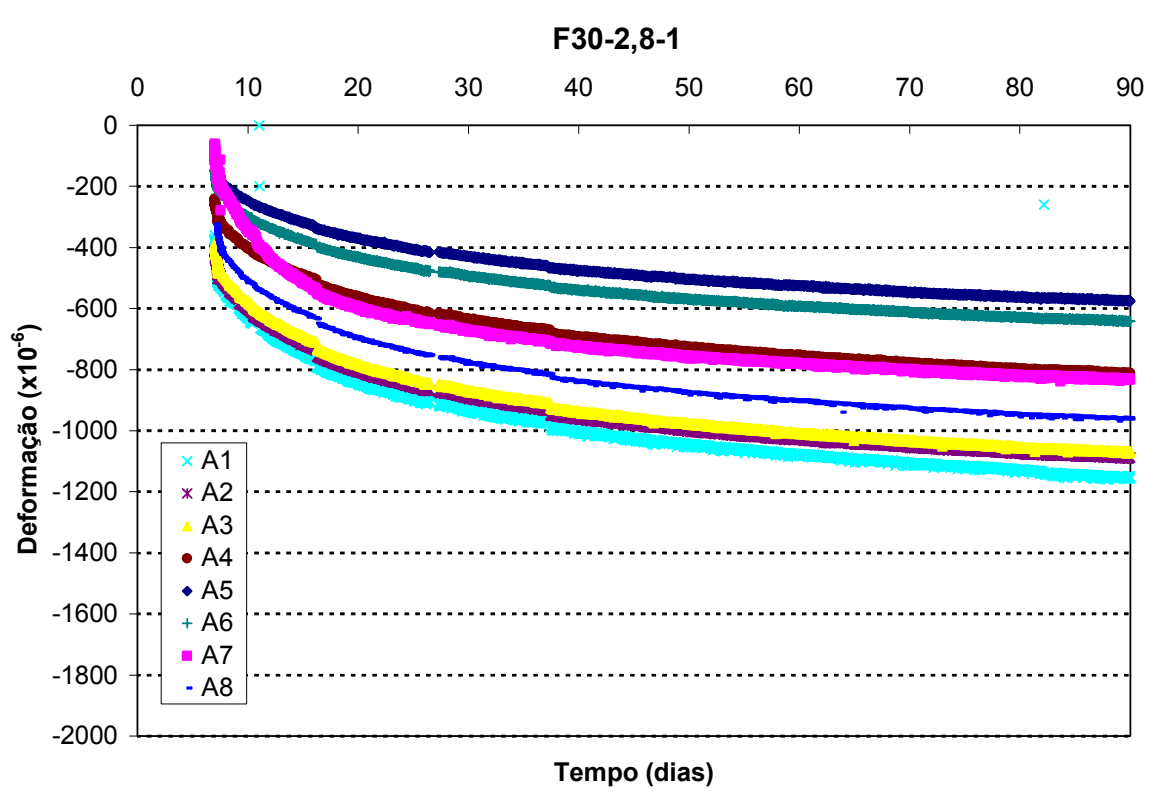

Gráfico 5.26 - Deformação nas armaduras do pilar F30-2,8-1.

F30-2,8-1

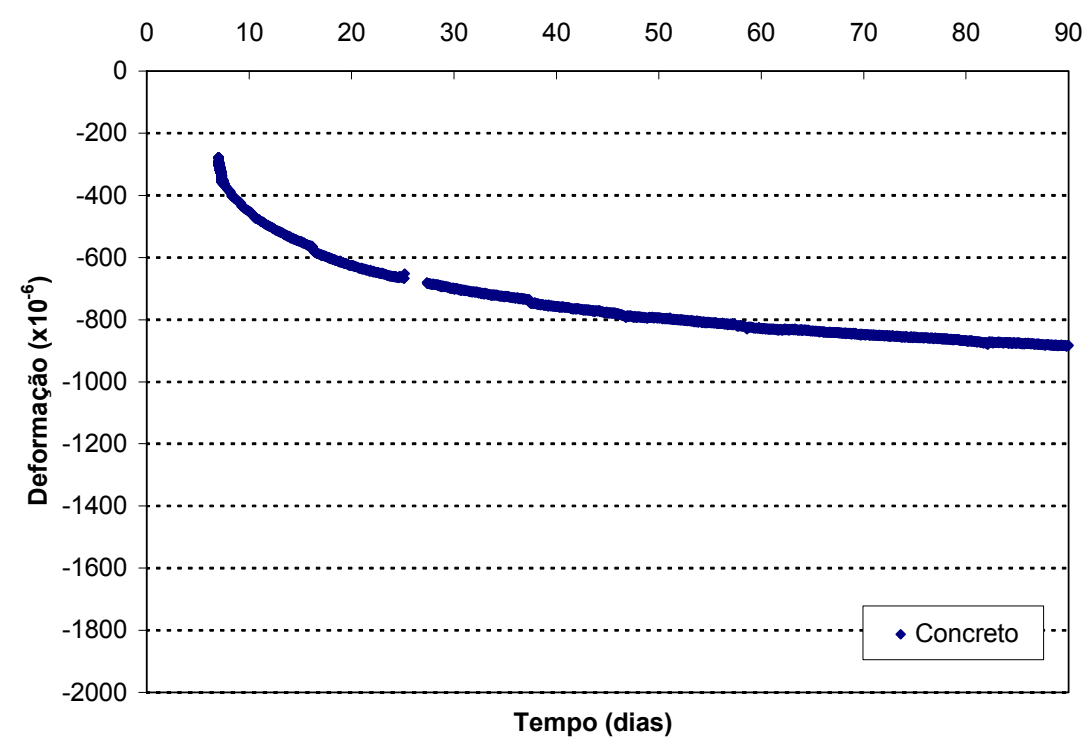

Gráfico 5.27 - Deformação no concreto do pilar F30-2,8-1.

5.5.1.4. $\mathrm{F} 40-1,4-1$

Os sensores das posições 1, 2, 3 e 4 funcionaram perfeitamente durante o período analisado.

Como pode ser visto no gráfico 5.28 , os sensores nas posições 1 e 2 apresentaram maiores deformações aos 91 dias de $1512 \times 10^{-6}$ e $1437 \times 10^{-6}$, respectivamente. Em 
média, as deformações das armaduras foram de $1371 \times 10^{-6}$, ou seja, maiores que às deformações dos pilares com taxa de armadura $2,8 \%$ e submetidos a $40 \%$ de tensão da resistência média à compressão aos 7 dias. No gráfico 5.29, é possível notar o mesmo comportamento das deformações para o concreto, ou seja, aos 91 dias o concreto apresenta deformação de $1345 \times 10^{-6}$.

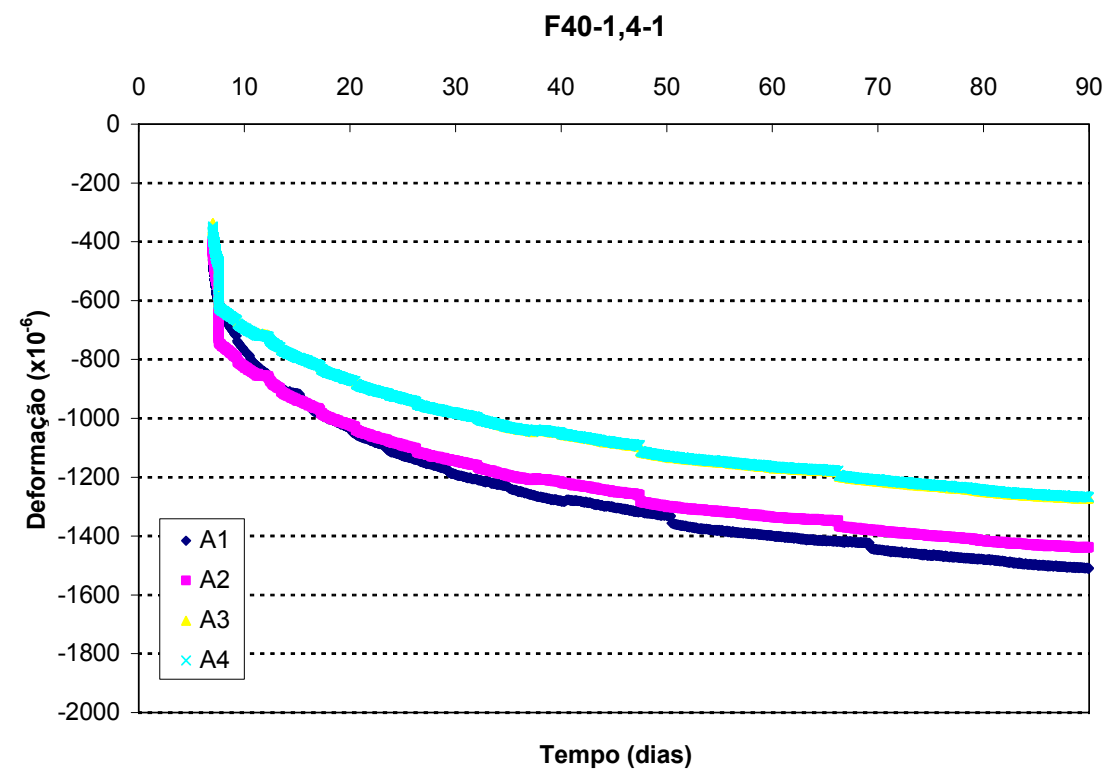

Gráfico 5.28 - Deformação nas armaduras do pilar F40-1,4-1.

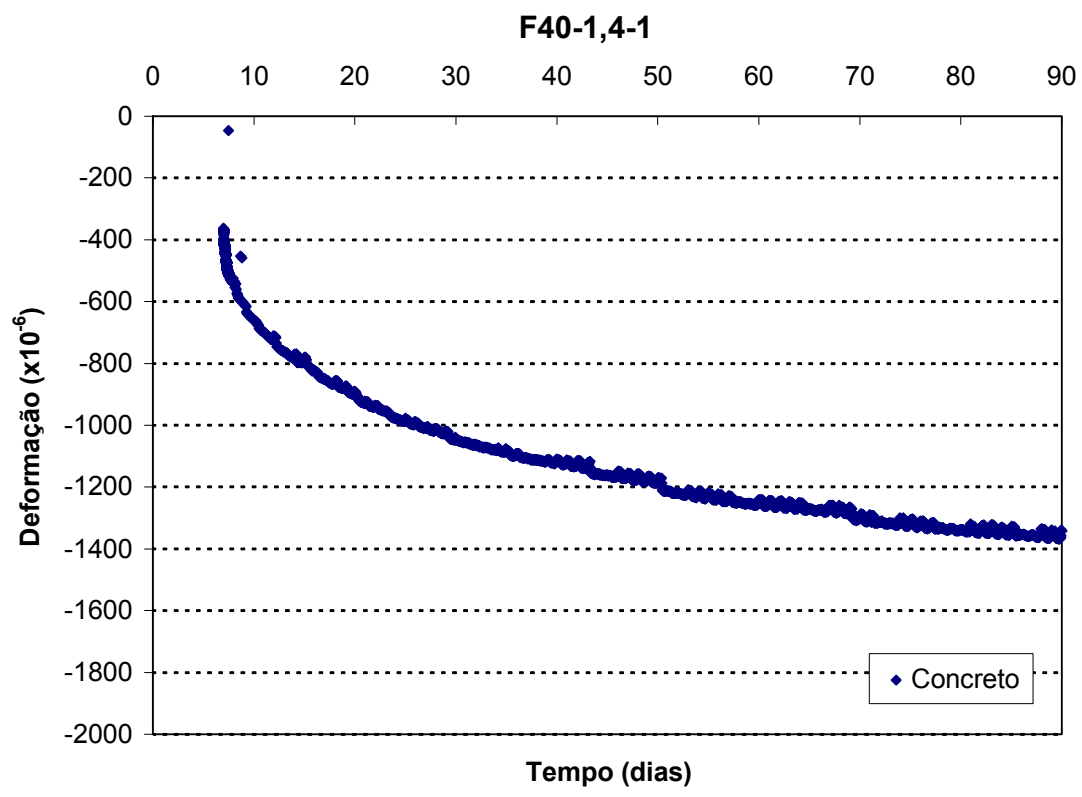

Gráfico 5.29 - Deformação no concreto do pilar F40-1,4-1. 
Todos os sensores instrumentados neste protótipo funcionaram perfeitamente.

Os sensores das posições 1 e 2 apresentaram maiores deformações $\left(1209 \times 10^{-6} \mathrm{e}\right.$ $1195 \times 10^{-6}$, respectivamente). A deformação média aos 91 dias nas armaduras é de $1088 \times 10^{-6}$.

No gráfico, é possível notar que a deformação no concreto $\left(1028 \times 10^{-6}\right)$ foi inferior àquela do pilar F40-1,4-1 devido à maior tensão aplicada no carregamento (gráfico 5.31).

F30-1,4-1

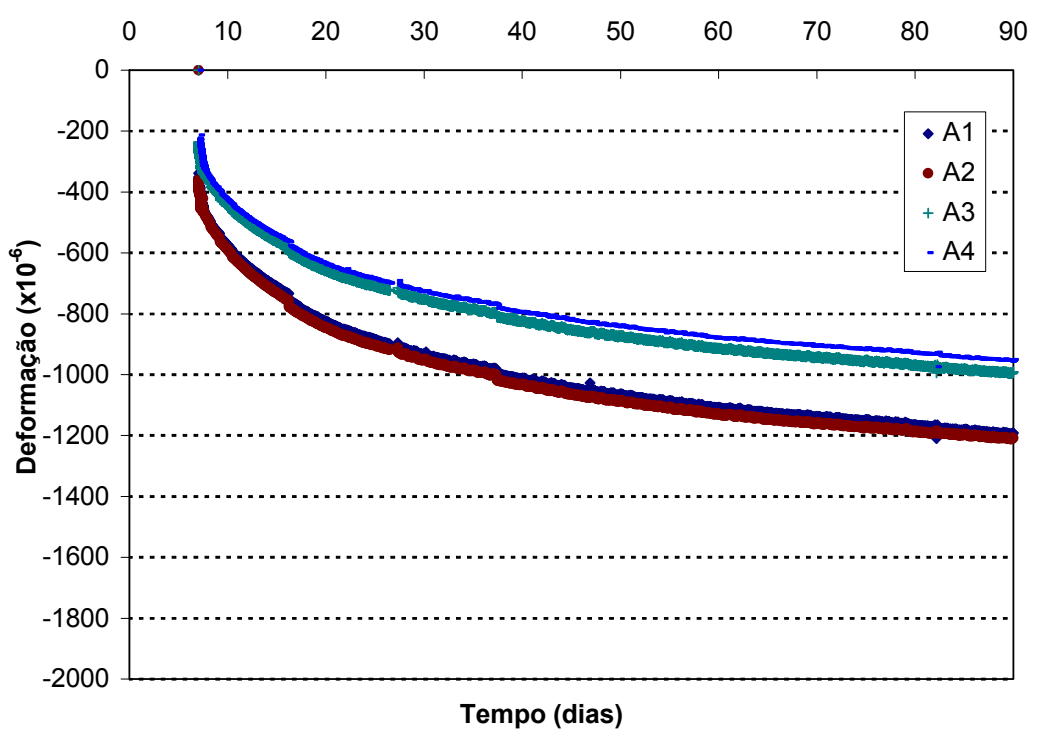

Gráfico 5.30 - Deformação nas armaduras do pilar F30-1,4-1. 
F30-1,4-1

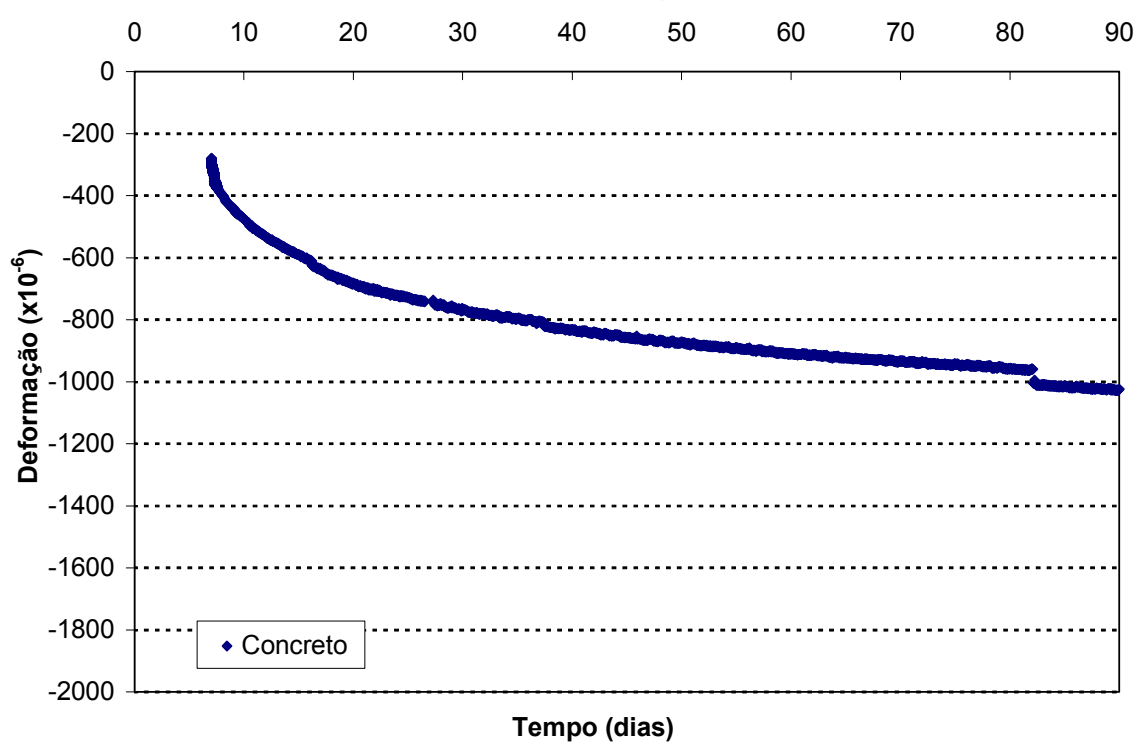

Gráfico 5.31 - Deformação no concreto do pilar F30-1,4-1.

5.5.1.6. $F 40-0,0-1$

O sensor de deformação de concreto imerso neste protótipo funcionou perfeitamente.

No gráfico 5.32, é interessante observar que a deformação inicial medida (407×10$\left.{ }^{6}\right)$ é semelhante à deformação calculada $\left(391 \times 10^{-6}\right)$. Como era esperado, este protótipo apresentou a maior deformação no concreto aos 91 dias de $1820 \times 10^{-6}$.

F40-0,0-1

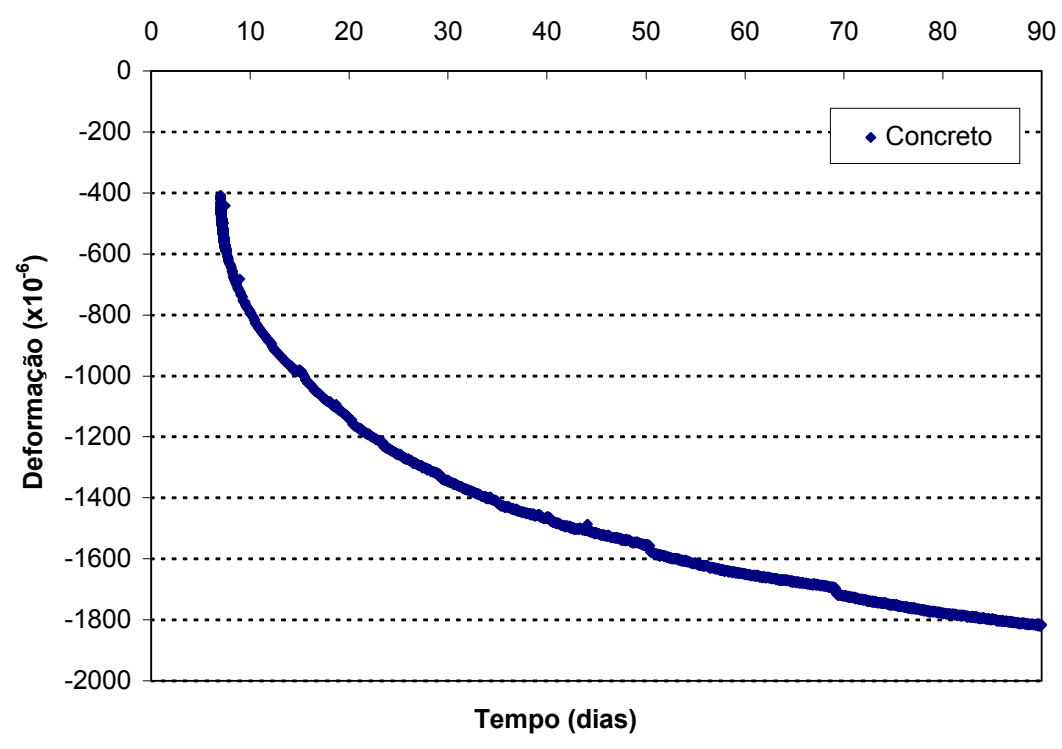

Gráfico 5.32 - Deformação no concreto do pilar F40-0,0-1. 


\subsubsection{7. $\mathrm{R}-2,8-1$}

O sensor utilizado para medição de deformação por retração do concreto deste protótipo funcionou corretamente durante todo o período analisado.

O protótipo R-2,8-1 não foi carregado e foram medidas apenas as deformações por retração. Como pode ser visto no gráfico 5.33, este protótipo apresentou deformação por retração inferior $\left(273 \times 10^{-6}\right)$ ao pilar R-1,4-1 devido à maior taxa de armadura $(2,8 \%)$ ter restringido as deformações ao longo do tempo.

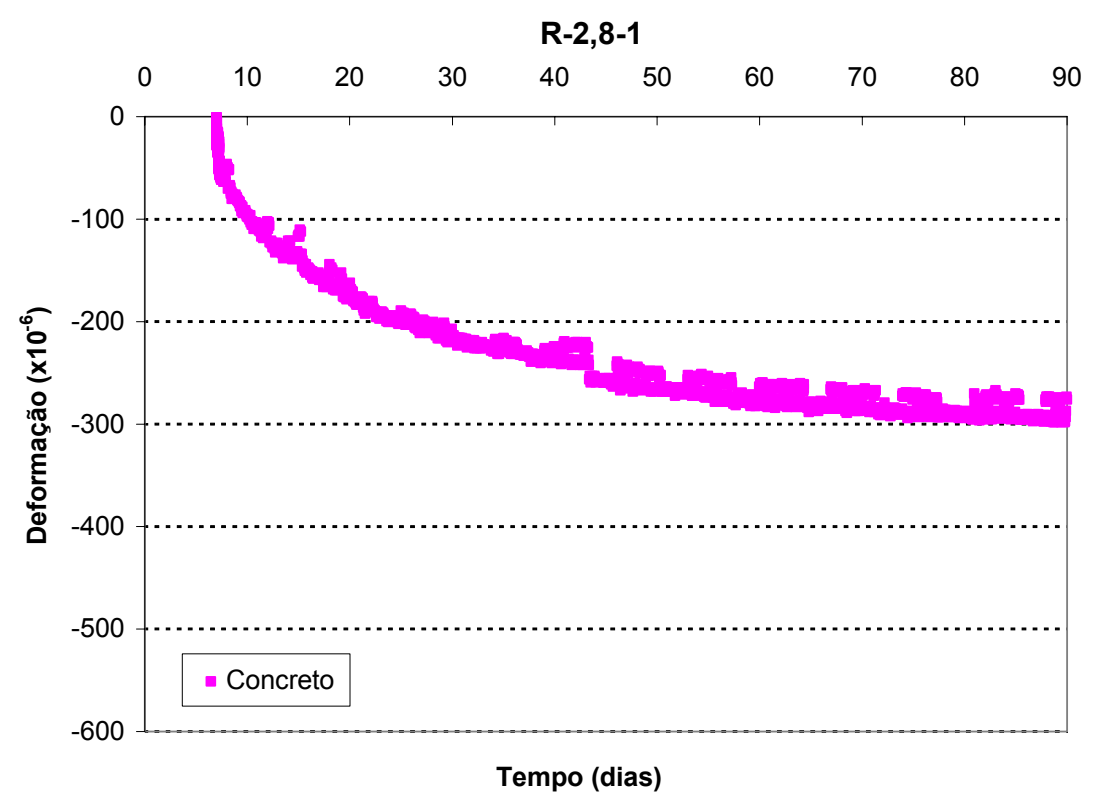

Gráfico 5.33 - Deformação no concreto do pilar R-2,8-1.

5.5.1.8. R-1,4-1

Não houve problemas decorrentes da instrumentação e o sensor apresentou perfeito funcionamento.

No gráfico 5.34 são apresentadas as deformações por retração do pilar R-1,4-1 para o período de 91 dias. A taxa de armadura de 1,4\% também restringiu a deformação por retração, embora de forma menos expressiva que no pilar com taxa de 2,8\%. Aos 91 dias, a deformação foi de $327 \times 10^{-6}$. 


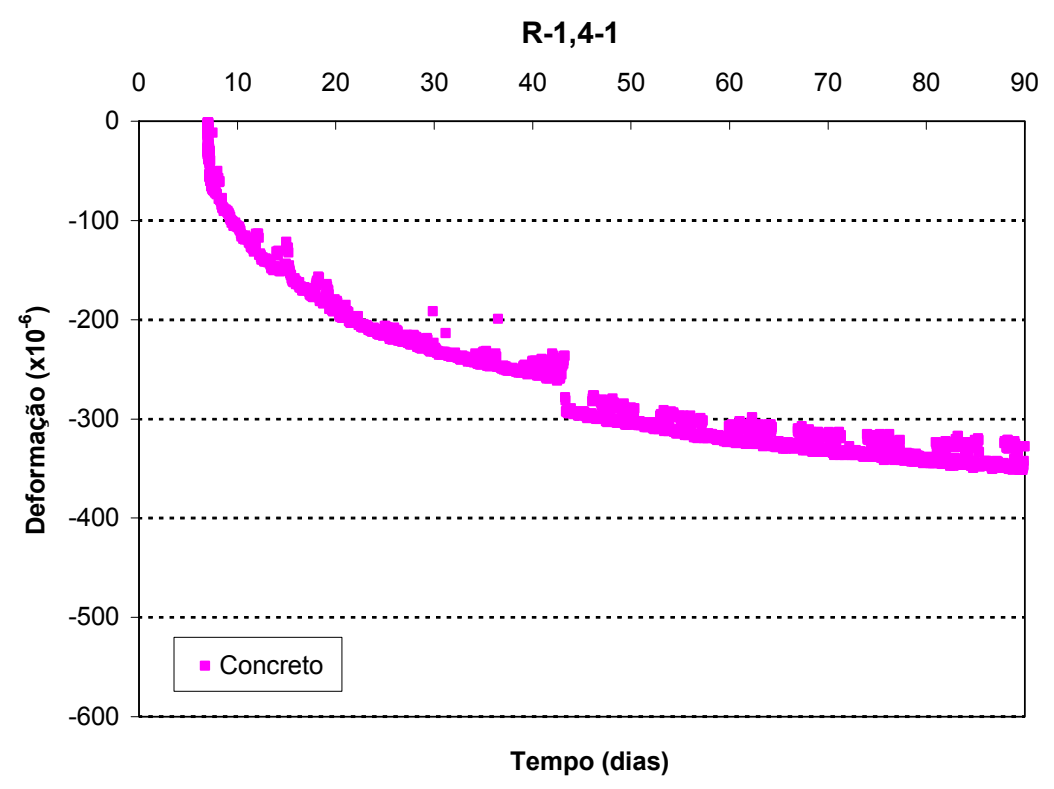

Gráfico 5.34 - Deformação no concreto do pilar R-1,4-1.

5.5.1.9. $\mathrm{R}-0,0-1$

O sensor que mediu as deformações por retração funcionou perfeitamente.

O gráfico 5.35 mostra as deformações por retração livre do protótipo R-0,0-1. Como era esperado, o protótipo R-0,0-1 apresentou as maiores deformações por retração $\left(377 \times 10^{-6}\right)$, pois não foram restringidas pela armadura.

R-0,0-1

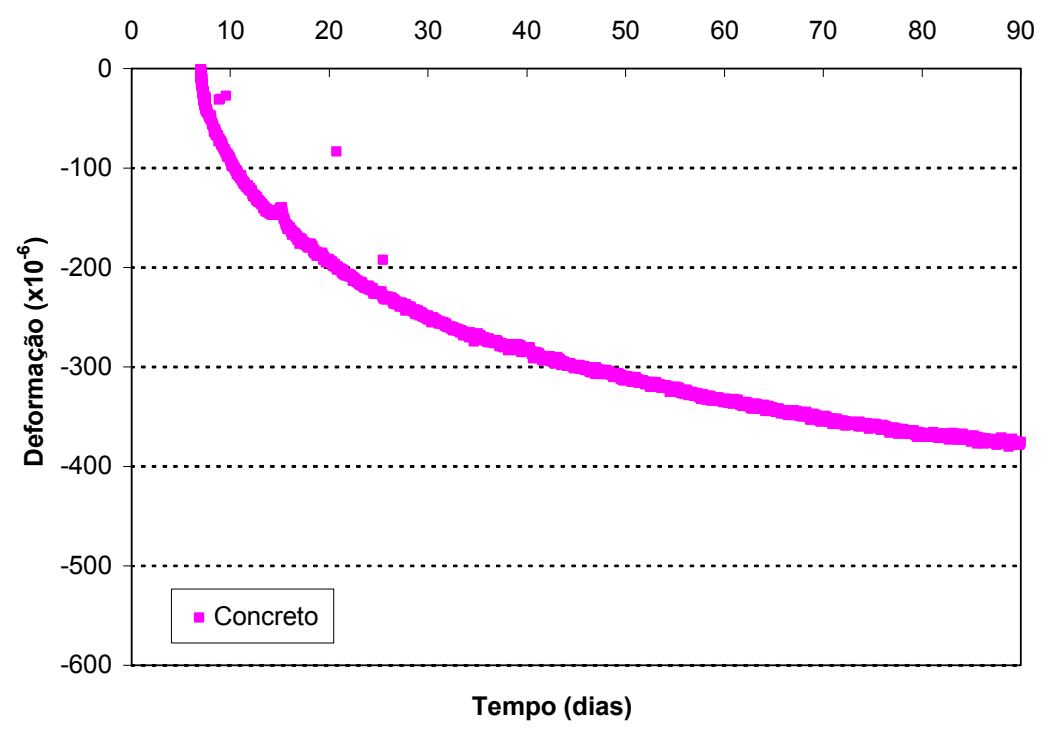

Gráfico 5.35 - Deformação no concreto do pilar R-0,0-1. 
5.5.2 Análises dos resultados experimentais

Primeiramente, é possível notar que as deformações iniciais tanto das armaduras quanto do concreto são muito próximas, como era esperado. Além disso, a maior parte das deformações de fluência e retração ocorrem nas primeiras 4 semanas. Este período da taxa de crescimento da fluência coincide com o período que o concreto tem menor resistência média à compressão, verificado no item 5.2. Nos pilares também não foi verificado escoamento da armadura, embora os pilares com menor taxa de armadura $(1,4 \%)$ tenham apresentado as maiores deformações.

A média de deformações das armaduras foi muito semelhante à deformação do concreto correspondente para 91 dias, como pode ser visto na tabela 5.9. Isto demonstra que houve boa aderência entre a armadura e o concreto.

Tabela 5.9 - Deformação da armadura e do concreto $\left(\times 10^{-6}\right)$ aos 91 dias e diferença percentual (\%).

\begin{tabular}{|c|c|c|c|c|c|}
\hline \multirow{2}{*}{ Pilar } & \multicolumn{2}{|c|}{ Tensão (MPa) } & \multicolumn{2}{|c|}{ Deformação $\left(\times 10^{-6}\right)$} & \multirow{2}{*}{$\begin{array}{c}\text { Diferença } \\
\text { deformação (\%) }\end{array}$} \\
\hline & Armadura & Concreto & Armadura & Concreto & \\
\hline F40-2,8-1 & 225,1 & 4,63 & 1148 & 1072 & 6,6 \\
\hline $\mathrm{F} 40-2,8-2$ & 215,1 & 5,04 & 1125 & 1027 & 8,7 \\
\hline F40-1,4-1 & 282,5 & 6,7 & 1371 & 1345 & 1,9 \\
\hline F30-2,8-1 & 185,0 & 3,2 & 895 & 885 & 1,1 \\
\hline F30-1,4-1 & 215,5 & 5,1 & 1088 & 1028 & 5,5 \\
\hline $\mathrm{F} 40-0,0-1$ & - & 10,5 & - & 1820 & - \\
\hline R-2,8-1 & - & - & - & 273 & - \\
\hline $\mathrm{R}-1,4-1$ & - & - & - & 327 & - \\
\hline $\mathrm{R}-0,0-1$ & - & - & - & 377 & - \\
\hline
\end{tabular}

Comparando a retração dos pilares com taxa de armadura 2,8 e 1,4\% (gráficos 5.33 e 5.34), é possível notar que até 4 semanas a deformação é praticamente a mesma. Após este período a taxa de crescimento das deformações é maior para os pilares com menor taxa de armadura. Slater e Lyse (1931) e Lyse e Kreidler (1932) chegaram às mesmas conclusões analisando pilares com diversas taxas de armadura. 
Utilizando o princípio da superposição foram determinadas as deformações por fluência, assim como a fluência específica para 91 dias. A deformação por fluência é a diferença da deformação do pilar carregado pela deformação do pilar correspondente descarregado. A fluência específica é calculada dividindo a deformação por fluência dos pilares submetidos a 40 ou $30 \%$ pelas tensões correspondentes (10,5 ou 8,03 $\mathrm{MPa}$, respectivamente), de acordo com a tabela 5.10 .

Como não foi ensaiada à fluência do pilar sem armadura com taxa de carregamento de $30 \%$, a deformação destes protótipos foi calculada a partir do resultado da deformação do protótipo sem armadura carregado a $40 \%$, pois há linearidade entre tensão deformação neste nível de tensão aplicada. Primeiramente, foi determinada a fluência específica do pilar submetido a $40 \%$ de carregamento. Em seguida, esta fluência específica foi multiplicada pela tensão de $8,03 \mathrm{MPa}$, obtendo-se a deformação por fluência do pilar sem armadura a $30 \%$. Somando esta deformação à retração do pilar correspondente, obtém-se a deformação teórica dos pilares armados carregados a $30 \%$.

Como já era esperado, nos pilares com mesma taxa de armadura submetidos às tensões distintas, a fluência específica é muito próxima. Creus (1986) afirma que para tensões até $40 \%$ da resistência do concreto há linearidade da deformação por fluência e nível de tensão.

Tabela 5.10 - Fluência específica $\left(\times 10^{-6} / \mathrm{MPa}\right)$ e deformação por fluência e retração $\left(\times 10^{-6}\right)$ aos 91 dias.

\begin{tabular}{ccccc}
\hline Tensão & $\begin{array}{c}\text { Taxa de } \\
\text { armadura (\%) }\end{array}$ & \multicolumn{2}{c}{ Deformação $\left(\times 10^{-6}\right)$} & $\mathrm{J}\left(\times 10^{-6} / \mathrm{MPa}\right)$ \\
& Fluência & Retração & \\
\hline \multirow{3}{*}{$40 \%$} & 2,8 & 777 & 273 & 74 \\
& 1,4 & 1018 & 327 & 97 \\
& 0 & 1443 & 377 & 137 \\
$30 \%$ & 2,8 & 612 & 273 & 76 \\
& 1,4 & 701 & 327 & 87 \\
\hline
\end{tabular}

É interessante notar que as deformações por retração têm um efeito maior (31\%) na deformação total (fluência + retração) dos protótipos carregados com tensão de $30 \%$ da resistência média à compressão aos 7 dias. Nos protótipos carregados a 
$40 \%$, a retração corresponde a $24 \%$ da deformação total. Isso pode ser explicado pelo fato da retração ser um efeito independente do carregamento.

Na tabela 5.11 estão apresentados os resultados percentuais da restrição da taxa de armadura às deformações por fluência, por retração e total. Em média, as taxas de armadura de 2,8 e 1,4\% restringiram 41 e $28 \%$ às deformações no concreto até 91 dias, respectivamente.

Tabela 5.11 - Restrição das deformações de fluência e retração devido à taxa de armadura aos 91 dias (\%).

\begin{tabular}{ccccc}
\hline \multirow{2}{*}{ Tensão } & Taxa de & \multicolumn{3}{c}{ Restrição da deformação pela armadura (\%) } \\
& armadura (\%) & Fluência & Retração & Fluência + Retração \\
\hline \multirow{2}{*}{$40 \%$} & 2,8 & 46 & 28 & 42 \\
& 1,4 & 29 & 13 & 26 \\
$30 \%$ & 2,8 & 45 & 28 & 40 \\
& 1,4 & 36 & 13 & 31 \\
\hline
\end{tabular}

Para comparar resultados entre pilares e corpos de prova foram plotados os gráficos 5.36 e 5.37. No gráfico 5.36 as deformações dos corpos de prova e pilar sem armadura teóricos submetidos à tensão de 30\% foram determinadas utilizando o princípio da superposição.

É interessante notar que as deformações do protótipo sem armadura são maiores do que as dos corpos de prova durante todo o período analisado, apesar das relações volume superfície e área da seção transversal perímetro da seção transversal serem iguais $\left(V / S=A_{c} / U=3,75 \mathrm{~cm}\right)$. A partir dos resultados experimentais, é possível observar que a deformação de fluência por secagem dos pilares foi consideravelmente maior e preponderante quando comparada com a retração. Aos 91 dias a deformação dos protótipos foi de aproximadamente 16\% maior que a dos corpos de prova, tanto para tensão de $30 \%$ quanto para $40 \%$. Isto indica que, apesar dos modelos de previsão considerarem o efeito da geometria por meio das relações volume superfície e área da seção transversal pelo perímetro da seção transversal, estas relações não foram capazes de prever as deformações entre elementos com geometrias distintas estudadas nesta pesquisa. Isto implicaria no fato do ensaio de fluência por secagem de corpos de prova cilíndricos ser ineficaz na previsão de deformações em outro elemento com geometria distinta, fato já observado por Fintel e Khan (1969). Entretanto, quando 
há presença de armadura as deformações do concreto são reduzidas, possibilitando que a deformação dos corpos de prova seja capaz de prever as deformações destes elementos estruturais. De fato, nos pilares com taxa de armadura de $1,4 \%$ e $2,8 \%$, as deformações no concreto foram inferiores à dos corpos de prova, embora os corpos de prova superestimem exageradamente as deformações para a taxa de armadura de $2,8 \%$. Aos 91 dias os corpos de prova submetidos à tensão tanto de $40 \%$ quanto de $30 \%$ têm deformação de aproximadamente $30 \%$ e $12 \%$ maiores que os protótipos com taxas da armadura de $2,8 \%$ e 1,4, respectivamente. Esta diferença aumenta para os protótipos com maior taxa de armadura devido à restrição da armadura. Portanto, considera-se importante levar em conta um coeficiente de geometria mais eficiente nas previsões de deformações de fluência e retração. Holm e Pistrang (1966) concluíram que corpos de prova cilíndricos e pilares com seção retangular com relação volume superfície semelhante apresentam coeficiente de 0,8 , pois analisaram pilares com seções transversais maiores.

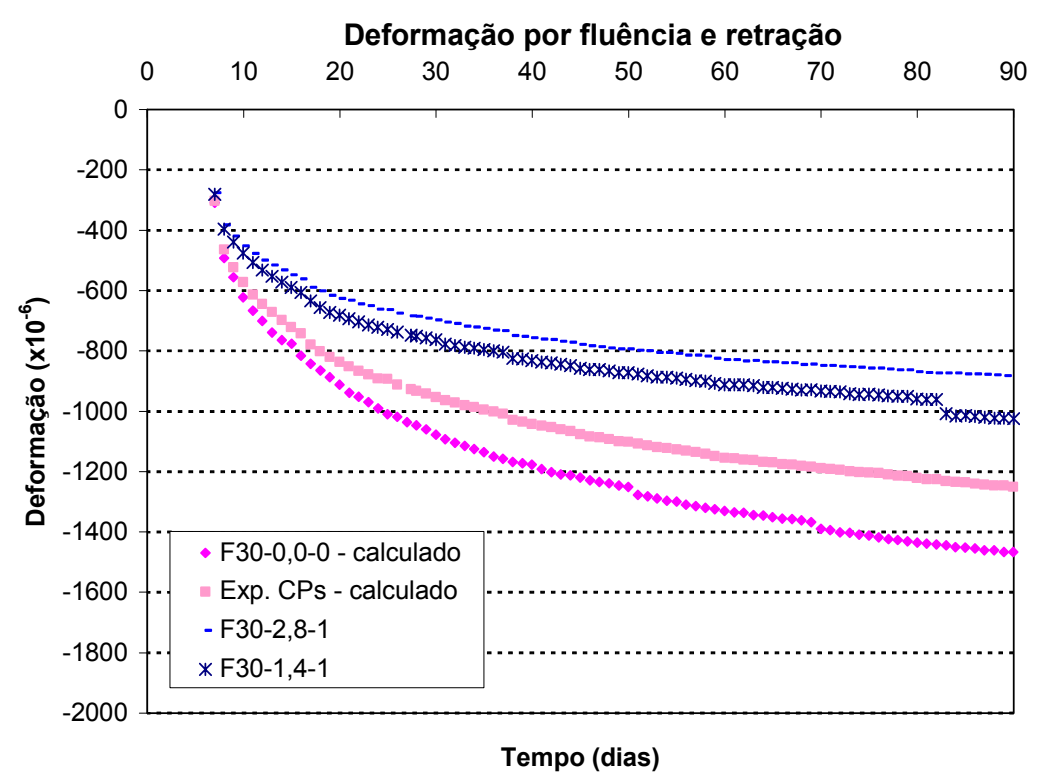

Gráfico 5.36 - Deformação por fluência e retração com tensão de $\mathbf{3 0} \%$. 


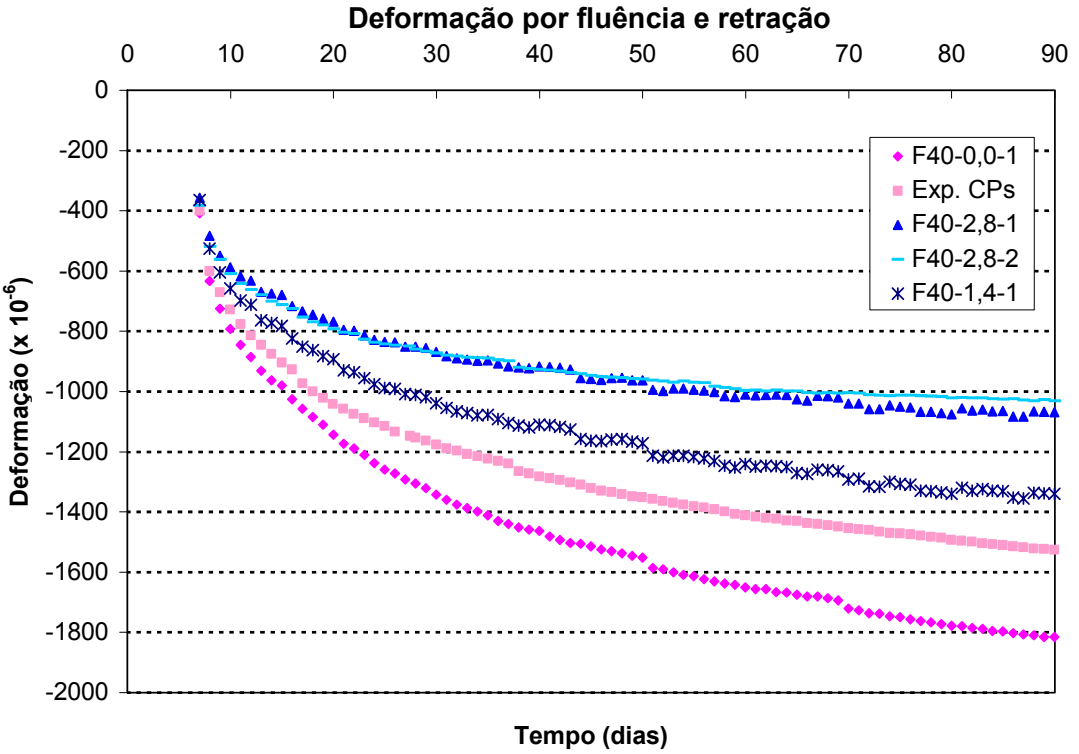

Gráfico 5.37 - Deformação por fluência e retração com tensão de $\mathbf{4 0} \%$. 


\section{CAPÍTULO 6}

\section{SIMULAÇÃO NUMÉRICA DOS PROTÓTIPOS DE PILARES}

A modelagem numérica é capaz de fornecer uma previsão dos resultados experimentais, simulando o comportamento de estruturas ou elementos estruturais. Tendo em vista a previsão do comportamento experimental dos protótipos de pilares quando estes estão submetidos a carregamento constante por longo tempo, foram feitas simulações numéricas utilizando o programa Diana 9.3 (Dlsplacement Method ANAlyser). Diana é um programa baseado no Método dos elementos finitos (MEF) utilizado para simulação numérica de estruturas, desenvolvido pela TNO Building and Construction Research na Holanda (WITTE, 2004).

Neste capítulo está apresentada a simulação numérica dos protótipos de pilares em 3D propostos experimentalmente, considerando as propriedades de fluência e retração. Como previsões destas propriedades analisadas são utilizadas as curvas de fluência e retração do modelo ACl209 (1982) disponível no programa Diana e a calibração da simulação numérica com as curvas experimentais de fluência e retração do corpo de prova do Traço II e as curvas experimentais do pilar sem armadura F40-0,0-1. Os resultados obtidos numericamente são comparados e analisados com os resultados experimentais. Além disso, são feitas comparações com os modelos de previsão do ACl, B3, EC2, GL e NBR, descritos no capítulo 2.

\subsection{Modelo de elementos finitos dos materiais}

$\mathrm{Na}$ modelagem do concreto sob estado plano de tensões, utilizam-se elementos isoparamétricos de 20 nós. Este elemento é baseado na interpolação quadrática e na integração de Gauss e possui três graus de liberdade por nó x, y e z. A deformação e a tensão variam linearmente em uma direção e quadraticamente nas outras duas direções. 
As barras de armadura são modeladas utilizando representação discreta com dois nós. Nesta representação, considera-se a armadura como elemento tipo treliça com nós coincidentes com os da malha de elementos finitos de concreto. A armadura é distribuída uniformemente no elemento de concreto, sendo cada conjunto de barras de armadura substituído por uma camada bidimensional de espessura e área equivalente. No Diana está disponível o modelo de ruptura de Von Mises com a equação constitutiva do material seguindo um modelo elastoplástico perfeito ou elasto-plástico com endurecimento para representar o comportamento do aço.

\subsection{Modelos de fluência e retração no Diana}

No Diana, efeitos de longa duração, como a fluência, podem ser modelados utilizando os modelos viscoelásticos Power Law, de Maxwell-Chain e Kelvin-Chain. O programa computacional também pode gerar os parâmetros nos modelos em série de Maxwell e Kelvin, onde os dados de entrada pode ser uma função discreta da fluência ou relaxação (por exemplo, curva experimental), ou utilizar modelos disponíveis no programa (CEB-FIP MODEL CODE, 1990; ACI209, 1982; NEN 6720 MODEL CODE, 1995 E JSCE MODEL CODE, 1999).

A curva de fluência experimental é modelada utilizando o modelo viscoelásticos de Maxwell-Chain que consiste em diversas molas paralelas e amortecedores em série (figura 6.1). Onde $E_{x}$ é a rigidez da mola e $\eta_{x}$ é a viscosidade do amortecedor.

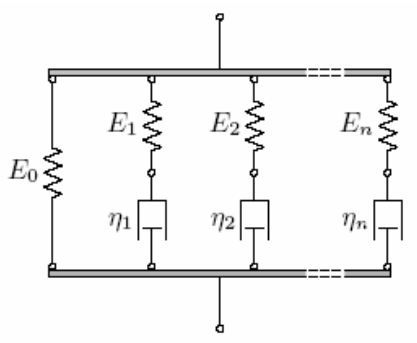

Figura 6.1 - Modelo de Maxwell-Chain (Fonte: Manual do Diana).

A forma geral de entrada das deformações por retração é feita utilizando a função discreta por meio de resultados experimentais e curvas derivadas dos modelos CEB-FIP Model Code (1990), ACI209 (1982) e NEN 6720 Model Code (1995) 
disponíveis no Diana. A idade do início da secagem é utilizada como dado de entrada das funções discretas.

Os protótipos de pilares foram modelados utilizando as curvas de fluência e retração obtidas experimentalmente e obtidas a partir do modelo do $\mathrm{ACl}$. Apesar de haver diversos modelos de fluência e retração disponíveis no Diana, as simulações numéricas foram feitas utilizando apenas o modelo do $\mathrm{ACl}$, pois esta pesquisa não abrangeu o estudo dos demais modelos.

\subsection{Modelos numéricos dos protótipos de pilares}

O comportamento à fluência e retração de protótipos de pilares foi analisado para três taxas de armadura longitudinal de 1,4\%, 2,8\% e 0\%.

Nos modelos de pilares foi aplicada carga distribuída (P) constante de 10,5 e 8,03 $\mathrm{N} / \mathrm{mm}^{2}$ na linha superior do pilar, que corresponde a 40 e $30 \%$ da resistência média à compressão aos 7 dias, respectivamente, como pode ser visto na figura 6.2.

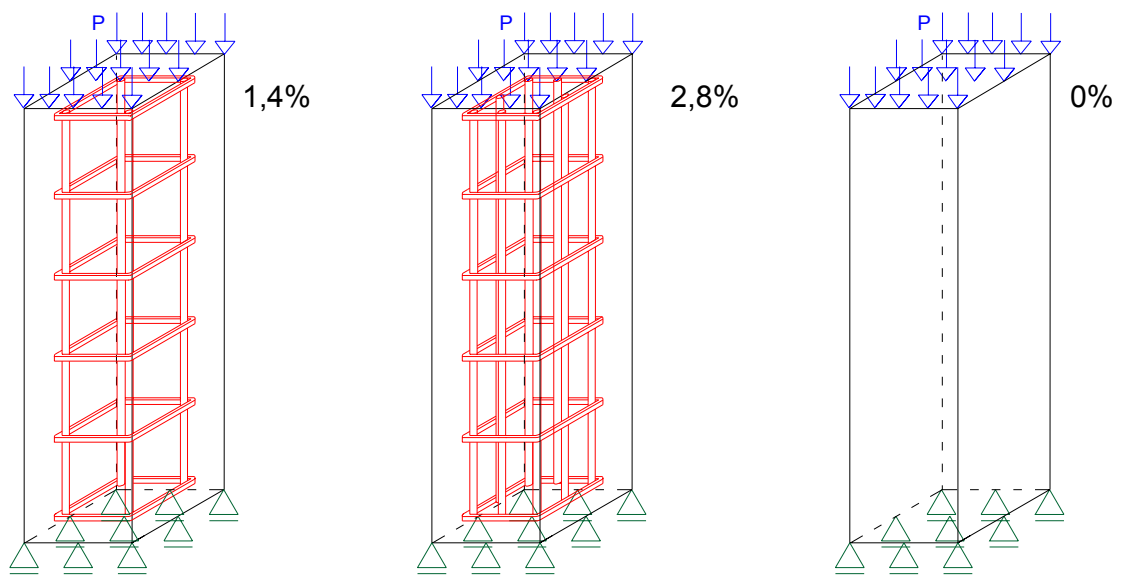

Figura 6.2 - Modelos numéricos dos protótipos de pilares (1,4, 2,8 e 0\%).

O concreto é considerado material isotrópico e linear elástico. Foi adotado coeficiente de Poisson de 0,2. As propriedades dos materiais (concreto e armadura) para os protótipos de pilares estão apresentadas na Tabelas 6.1 e 6.2. 
Tabela 6.1 - Propriedades do concreto dos protótipos de pilares.

Propriedade mecânica do concreto

\begin{tabular}{cc}
\hline$f_{\mathrm{cm} 7}(\mathrm{MPa})$ & 26,2 \\
$\mathrm{f}_{\mathrm{cm} 28}(\mathrm{MPa})$ & 33,3 \\
$\mathrm{E}_{\mathrm{cm} 7}(\mathrm{GPa})$ & 26,8 \\
$\mathrm{E}_{\mathrm{cm} 28}(\mathrm{GPa})$ & 29,8 \\
\hline
\end{tabular}

Tabela 6.2 - Propriedades das armaduras dos protótipos de pilares.

Propriedades físicas e mecânicas das armaduras

\begin{tabular}{cccc} 
Tipo de armadura & Área $\left(\mathrm{cm}^{2}\right)$ & $\mathrm{f}_{\mathrm{y}}(\mathrm{MPa})$ & $\mathrm{E}_{\mathrm{s}}(\mathrm{GPa})$ \\
\hline Longitudinal & 3,15 & 635 & 217,4 \\
Estribo & 1,26 & 611 & 213,7 \\
\hline
\end{tabular}

Na simulação numérica que utilizou a curva de fluência e retração do modelo do $\mathrm{ACl}$ foi considerada umidade relativa de $60 \%$. O teor de ar e a consistência do concreto adotados foram obtidos experimentalmente sendo iguais a 3,9\% e 132 $\mathrm{mm}$, respectivamente. A espessura fictícia $(\mathrm{h}=150 \mathrm{~mm})$ foi obtida a partir da formulação fornecida pelo ACI318 (2005). É adotada a relação agregado miúdo por agregado total de $45 \%$. Para a simulação numérica considerando a retração são necessários alguns parâmetros extras de entrada, tais como: resistência à compressão média aos 28 dias $(33,3 \mathrm{MPa})$, temperatura ambiente $\left(23^{\circ} \mathrm{C}\right)$, período em que o concreto foi curado (7 dias) e consumo de cimento $\left(280 \mathrm{~kg} / \mathrm{m}^{3}\right)$.

Para a simulação dos modelos numéricos considerando a curva de fluência e retração experimental é necessária a alteração de um arquivo de entrada do Diana acrescentando os resultados experimentais nas propriedades do concreto. Como os protótipos estavam submetidos apenas à compressão sob carregamento em serviço, não foram utilizados modelos de fissuração.

A simulação das deformações por fluência e retração foi feita até os 91 dias, pois corresponde ao tempo em que o protótipo ficou carregado.

As malhas dos modelos estruturais $3 \mathrm{D}$ dos protótipos de pilares podem ser vistas na figura 6.3 e o número de nós e elementos dos modelos numéricos estão apresentados na tabela 6.3. Os elementos de concreto utilizados para as malhas dos modelos 3D são de 20 nós quadráticos definido como $\mathrm{CHX60}$ e os elementos das armaduras são do tipo treliça definido como L6TRU (figuras 6.4 e 6.5). 


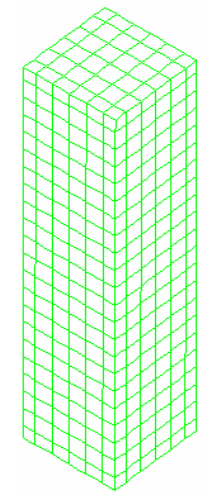

a-) $1,4 \%$

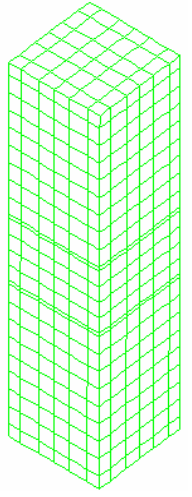

b-) $2,8 \%$

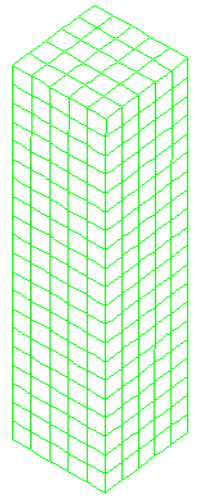

c-) $0 \%$

Figura 6.3 - Malha dos protótipos de pilares.

Tabela 6.3 - Número de nós e elementos dos modelos numéricos.

\begin{tabular}{ccc}
\hline Pilar & $\mathrm{n}^{\circ}$ nós & $\mathrm{n}^{\circ}$ elementos \\
\hline $1,4 \%$ & 4137 & 1144 \\
$2,8 \%$ & 4501 & 1406 \\
$\sim 0 \%$ & 2736 & 500 \\
\hline
\end{tabular}

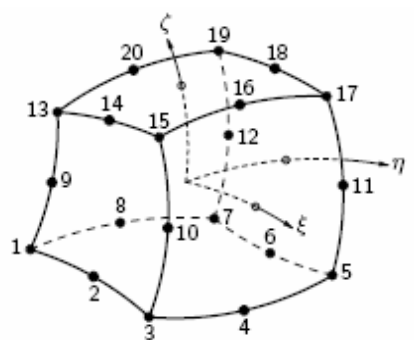

Figura 6.4 - Elemento CHX60 (Fonte: Manual do Diana).

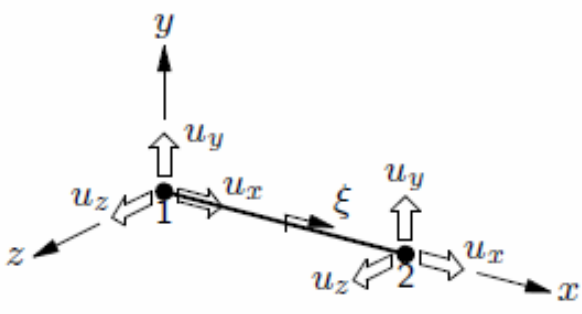

Figura 6.5 - Elemento L6TRU (Fonte: Manual do Diana).

\subsection{Resultados e análises da simulação numérica}

Neste item estão apresentados os resultados e análises da simulação dos modelos numéricos descritos no item 6.3. Os resultados numéricos destes modelos foram obtidos considerando as curvas de fluência e retração do modelo do $\mathrm{ACl}$, as curvas experimentais dos copos de prova cilíndricos do Traço II e as curvas experimentais do pilar P40-0,0-1. As análises são feitas para 91 dias em termos de deformações totais em $\times 10^{-6}$ e por retração em $\times 10^{-6}$, assim como fluência específica, expressas em $\times 10^{-6} / \mathrm{MPa}$. 
Para construção das curvas de deformações e tensões ao longo do tempo no concreto e na armadura, foram tabuladas as deformações dos nós da malha de elementos finitos, correspondentes às posições geométricas de interesse.

Para visualização dos resultados do programa foram gerados arquivos do tipo Femview e os resultados foram tratados em Excel. A partir dos arquivos gerados foram traçadas as curvas de deformações do concreto e da armadura considerando o modelo do $\mathrm{ACl}$ (gráficos 6.1 e 6.2, respectivamente), assim como a calibração de curvas experimentais de fluência e retração dos corpos de prova (gráficos 6.5 e 6.6, respectivamente) e do pilar (gráficos 6.9 e 6.10, respectivamente).

Além disso, foram gerados gráficos de tensão no concreto e na armadura ao longo de 91 dias calibradas com o modelo do $\mathrm{ACl}$ (gráficos 6.3 e 6.4, respectivamente), curva experimental dos corpos de prova (gráficos 6.7 e 6.8, respectivamente) e do pilar (gráficos 6.11 e 6.12, respectivamente).

$\mathrm{Na}$ legenda dos gráficos a nomenclatura define primeiramente a porcentagem de armadura dos pilares seguida da porcentagem da tensão aplicada. A nomenclatura de cada gráfico indica a curva de fluência e retração utilizada na simulação: $\mathrm{ACl}$ $(\mathrm{ACl})$, corpo de prova $(\mathrm{CP})$ e pilar $(\mathrm{P})$.

As isobandas das simulações numéricas de deformações e tensões no concreto aos 91 dias são apresentadas no Anexo C.

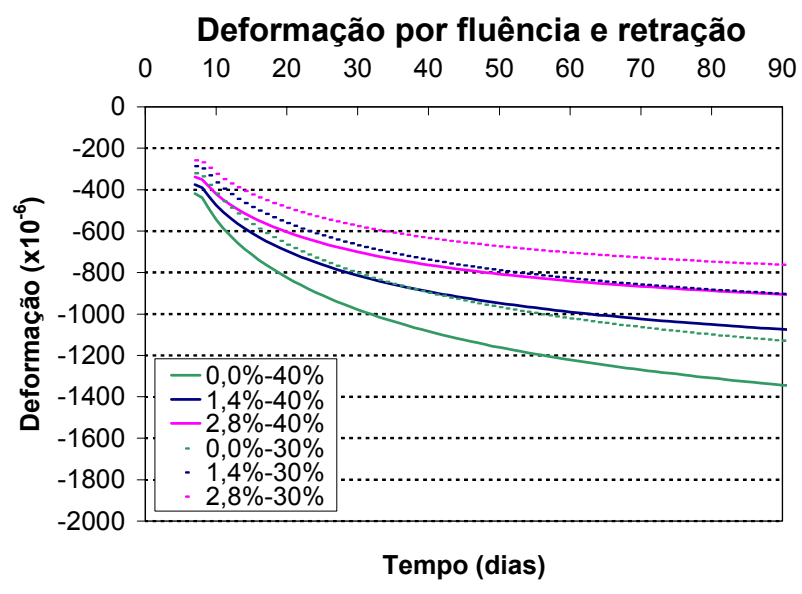

Gráfico 6.1 - Deformação no concreto (ACl).
Deformação por fluência e retração

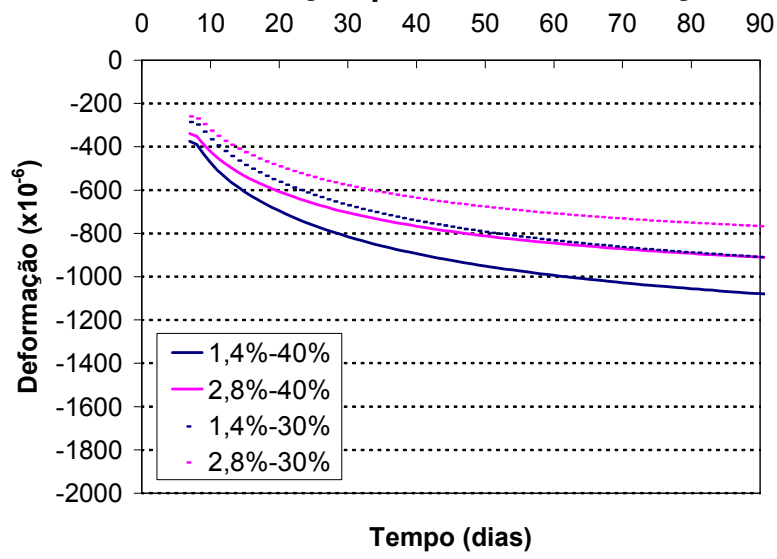

Gráfico 6.2 - Deformação na armadura (ACI). 
Perda de tensão no concreto

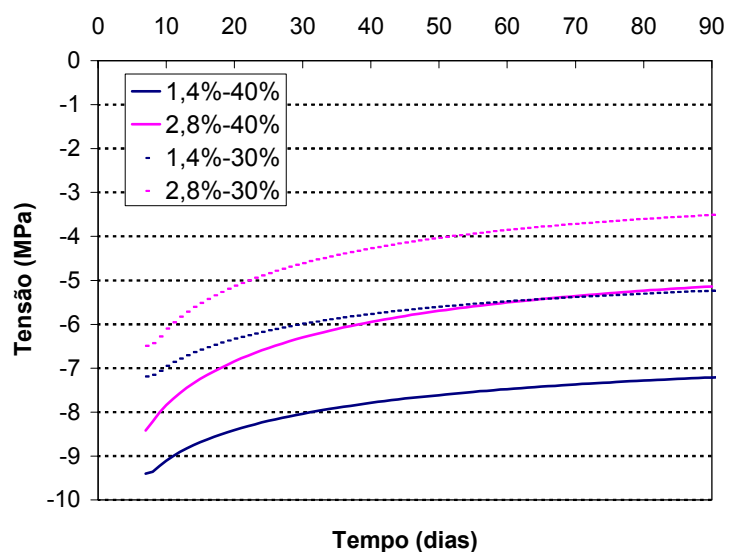

Gráfico 6.3 - Tensão no concreto (ACl).

Deformação por fluência e retração

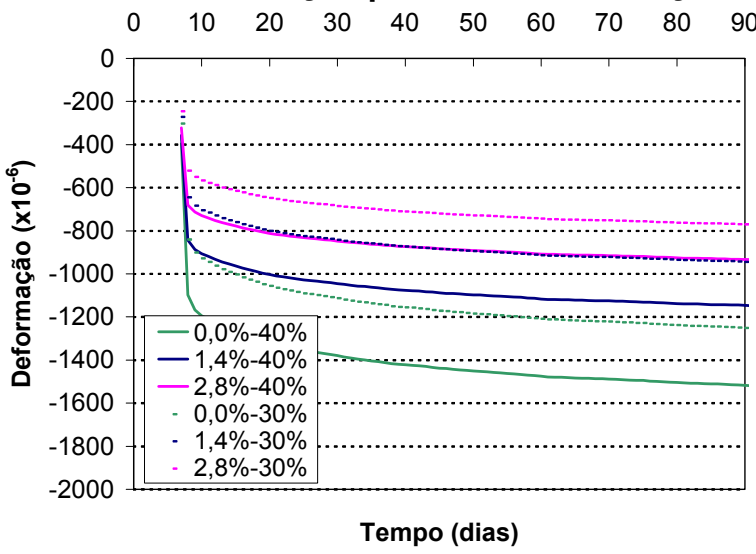

Gráfico 6.5 - Deformação no concreto (CP).

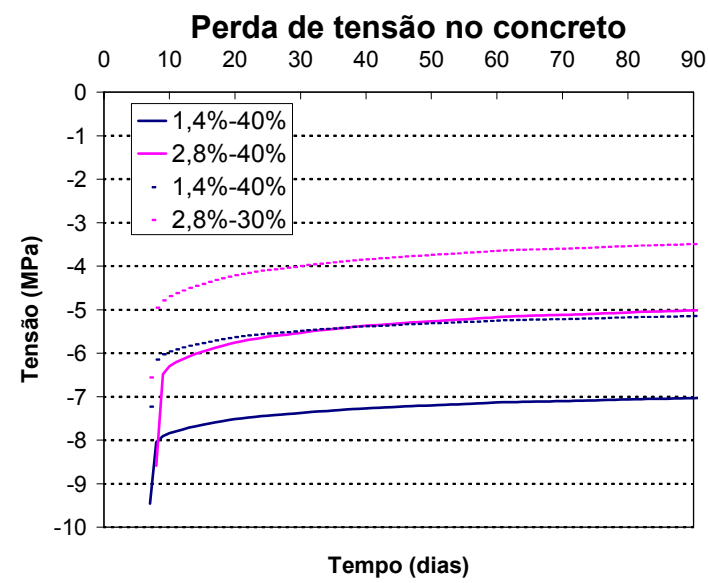

Gráfico 6.7 - Tensão no concreto (CP).
Ganho de tensão na armadura

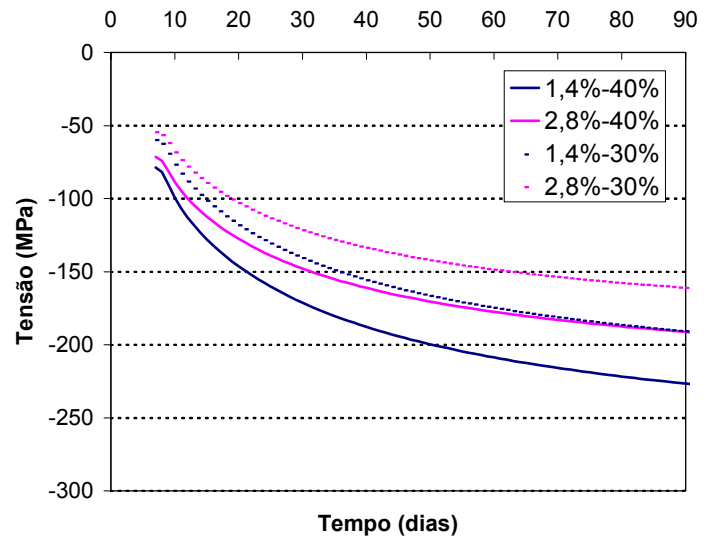

Gráfico 6.4 - Tensão na armadura ( $\mathrm{ACl})$.

Deformação por fluência e retração

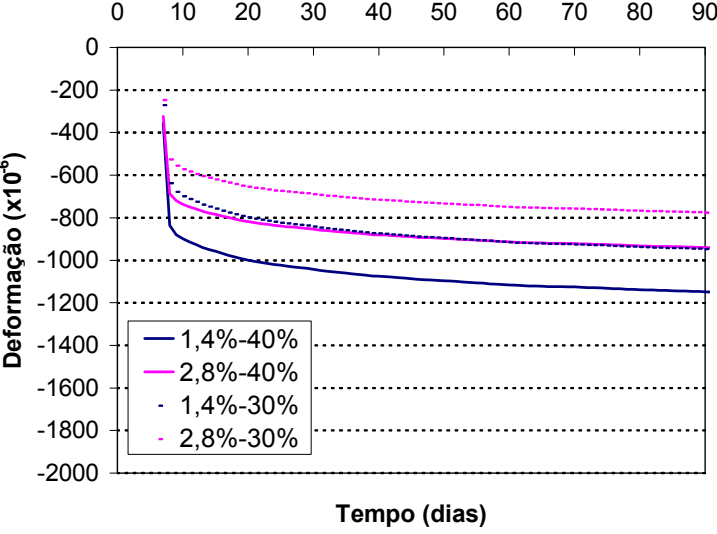

Gráfico 6.6 - Deformação na armadura (CP).

Ganho de tensão na armadura

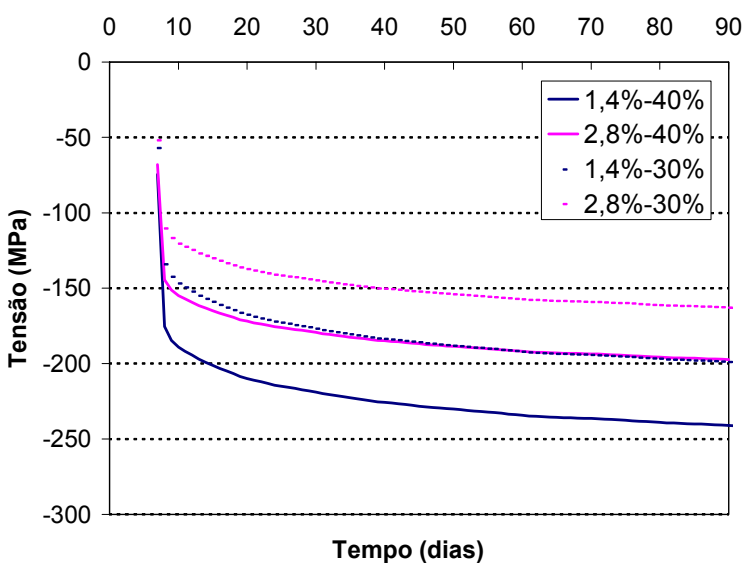

Gráfico 6.8 - Tensão na armadura (CP). 


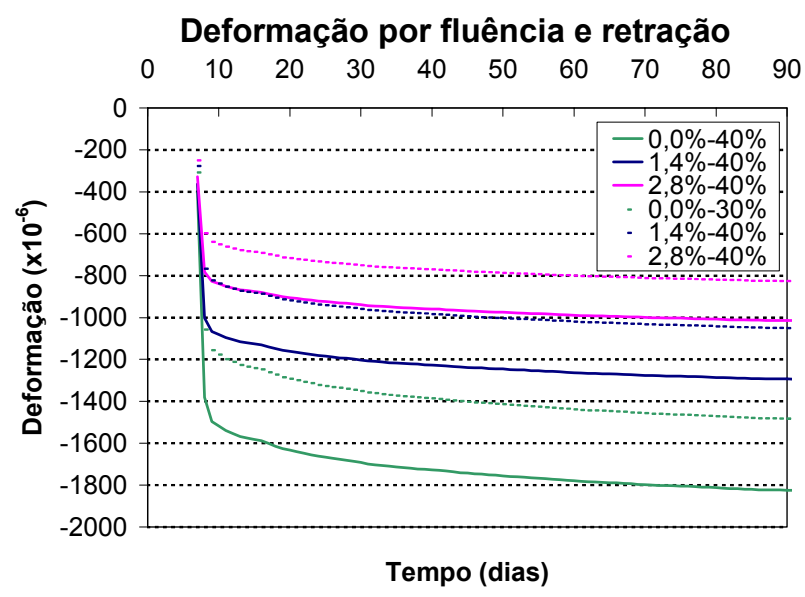

Gráfico 6.9 - Deformação no concreto (P).

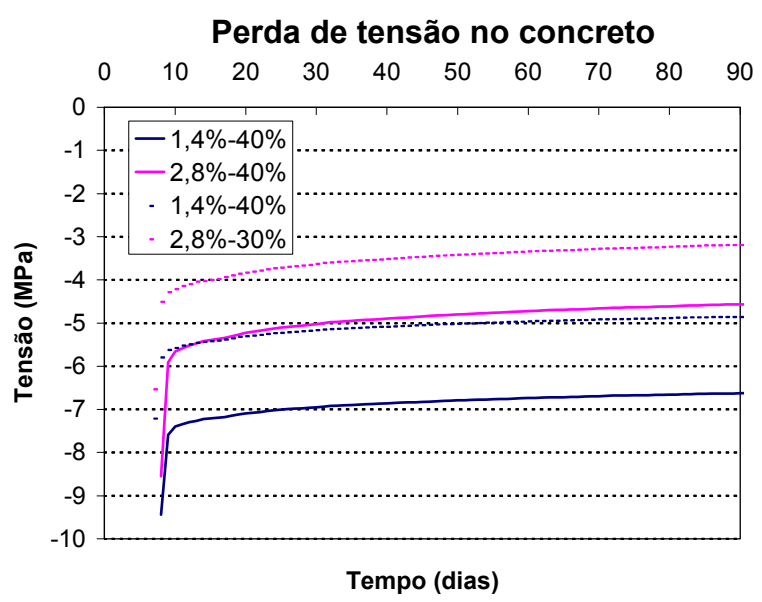

Gráfico 6.11 - Tensão no concreto $(P)$.
Deformação por fluência e retração

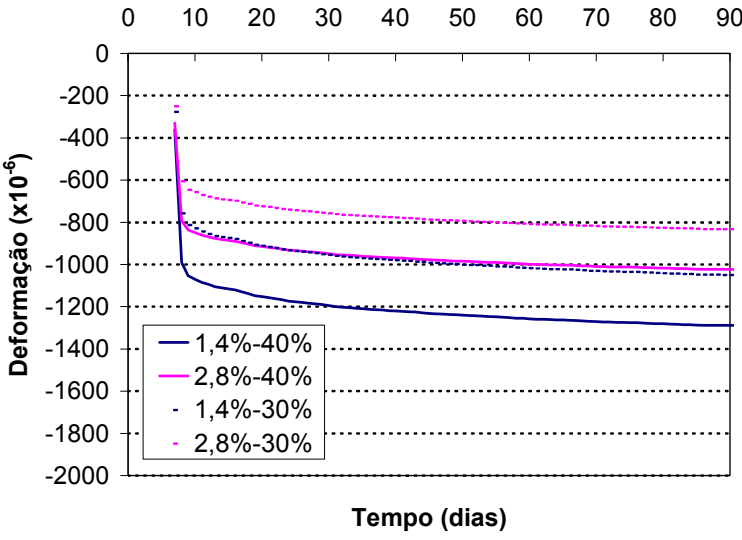

Gráfico 6.10 - Deformação na armadura (P).

Ganho de tensão na armadura

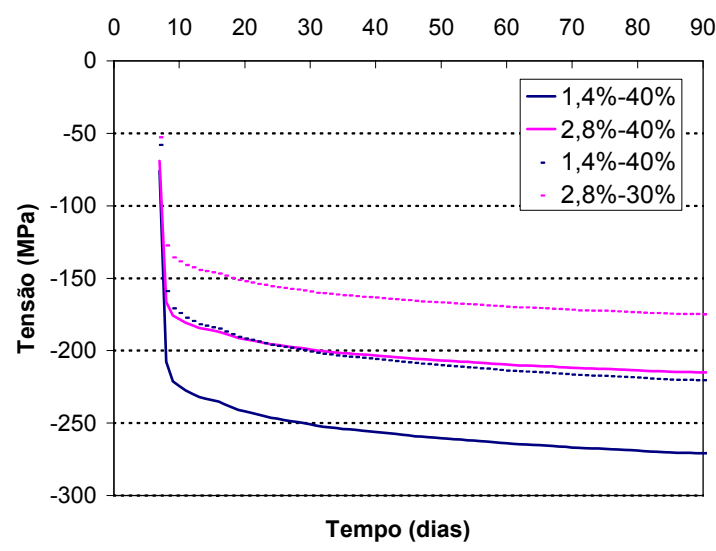

Gráfico 6.12 - Tensão na armadura $(P)$.

Como já era esperado, o pilar sem armadura apresentou maior deformação por fluência e retração, pois não houve restrição das deformações pela taxa de armadura (gráficos 6.1, 6.5 e 6.9). Considerando como referência o pilar somente de concreto, a armadura restringiu as deformações do concreto de forma mais significativa no pilar com taxa de armadura de $2,8 \%$ do que no pilar com taxa de $1,4 \%$, como pode ser visto na tabela 6.4 devido à maior taxa de armadura.

Para as curvas da simulação numérica calibradas com as diversas curvas de fluência e retração, foi verificado que houve maior transferência de carga do concreto para a armadura na simulação com a curva experimental do pilar tanto para os pilares taxa de armadura de 1,4\% (29\%) quanto para aqueles com taxa de armadura de $2,8 \%(44 \%)$, como pode ser visto na tabela 6.4 . Isto pode ser explicado pelo fato das deformações provenientes desta simulação serem as 
maiores (tabela 6.5). Dessa forma, quanto maior as deformações por fluência e retração há uma restrição maior das armaduras às deformações.

Tabela 6.4 - Restrição das deformações de fluência e retração devido à taxa de armadura aos 91 dias (\%).

\begin{tabular}{ccccc}
\hline \multirow{2}{*}{ Curva calibrada } & \multicolumn{3}{c}{ Taxa de armadura } \\
\cline { 2 - 5 } & \multicolumn{2}{c}{$1,4 \%$} & \multicolumn{2}{c}{$2,8 \%$} \\
\cline { 2 - 5 } & $40 \%$ & $30 \%$ & $40 \%$ & $30 \%$ \\
\hline ACl & 20 & 20 & 33 & 33 \\
CP & 24 & 24 & 38 & 38 \\
Pilar & 29 & 29 & 44 & 44 \\
\hline
\end{tabular}

Tabela 6.5 - Deformação de fluência e retração aos 91 dias no concreto $\left(\times 10^{-6}\right)$.

\begin{tabular}{ccccccc}
\hline \multirow{2}{*}{$\begin{array}{c}\text { Taxa de } \\
\text { armadura }\end{array}$} & \multicolumn{5}{c}{ Deformação para 91 dias } \\
\cline { 2 - 7 } & $40 \%$ & $30 \%$ & $40 \%$ & $30 \%$ & $40 \%$ & $30 \%$ \\
\hline $1,4 \%$ & 1076 & 905 & 1294 & 1051 & 1147 & 945 \\
$2,8 \%$ & 906 & 765 & 1014 & 826 & 934 & 771 \\
$0 \%$ & 1346 & 1133 & 1824 & 1484 & 1518 & 1252 \\
\hline
\end{tabular}

Tabela 6.6 - Deformação aos 91 dias na armadura $\left(\times 10^{-6}\right)$.

\begin{tabular}{ccccccc}
\hline \multirow{2}{*}{$\begin{array}{c}\text { Taxa de } \\
\text { armadura }\end{array}$} & \multicolumn{4}{c}{ Deformação para 91 dias } \\
\cline { 2 - 7 } & $40 \%$ & $30 \%$ & $40 \%$ & $30 \%$ & $40 \%$ & $30 \%$ \\
\cline { 2 - 7 } & 1081 & 911 & 1289 & 1050 & 1149 & 948 \\
$2,4 \%$ & 911 & 769 & 1024 & 833 & 940 & 776 \\
\hline
\end{tabular}

Nas isobandas apresentadas no Anexo $\mathrm{C}$ é possível notar que há acúmulo de tensões e deformações na base e no topo dos pilares. Entretanto, este acúmulo não influencia nos resultados, uma vez que o elemento da malha escolhido para análise corresponde à meia altura no eixo longitudinal do protótipo, onde há uma distribuição uniforme de tensão e deformação.

Além disso, pode-se observar nas isobandas do Anexo $C$ que os resultados não superaram o limite de deformação e tensão de escoamento da armadura. As armaduras que apresentam maiores deformações e, conseqüentemente, maiores tensões são os pilares com taxa de armadura de 1,4\%. Considerando as curvas das simulações calibradas com as curvas de fluência e retração, a tensão máxima 
da armadura é de $270 \mathrm{MPa}$ e a deformação máxima é de $1,29 \%$, para o pilares com taxa de armadura de $1,4 \%$, calibradas com a curva de fluência e retração do pilar e tensão de carregamento de $40 \%$, como podem ser vistos nas tabelas $6.5 \mathrm{e}$ 6.7. Isso implica que tanto a maior tensão quanto a maior deformação observadas são $36 \%$ da tensão última (743 $\mathrm{MPa}$ ) e $62 \%$ da deformação de escoamento $\left(\varepsilon_{\mathrm{u}}=2,07 \%\right.$ oo $)$. De acordo com Ziehl; Cloyd e Kreger (2004), apenas os pilares submetidos a $40 \%$ de tensão e com taxa de armadura de 0 a $0,72 \%$ excederam a deformação de escamento de $2,07 \%$ com idade inferior a 400 dias.

As tensões no concreto ao longo do tempo para os pilares 1,4 e 2,8\% podem ser vistas nos gráficos 6.3, 6.7 e 6.11. Comparando as tensões no concreto para os pilares com taxas de armaduras avaliadas (1,4 e 2,8 e $0 \%$ ) pode ser notado que ocorreu um alívio de tensões no concreto devido à presença da armadura. Este alívio foi maior para o pilar de taxa de armadura de $2,8 \%(\approx 55 \%)$ do que para a taxa de $1,4 \%(\approx 35 \%)$, como pode ser visto na tabela 6.7 . É interessante ressaltar que o pilar de taxa de armadura de $2,8 \%$ teve um alívio de praticamente metade da tensão a que está submetido, conseqüentemente, estas tensões foram transferidas para a armadura. Holm; Pistrang (1966) verificou que houve um alívio de $44 \%$ das tensões no concreto para uma taxa de armadura longitudinal de 3,1\%. Também é possível observar que calibrando a curva da simulação numérica com a curva experimental do pilar o alívio das tensões é sutilmente maior para ambas as taxas de armadura devido às deformações serem as maiores previstas, como pode ser visto na tabela 6.6.

Tabela 6.7 - Transferência de tensão do concreto para armadura aos 91 dias (\%).

\begin{tabular}{ccccc}
\hline \multirow{2}{*}{ Curva calibrada } & \multicolumn{3}{c}{ Taxa de armadura } \\
\cline { 2 - 5 } & \multicolumn{2}{c}{$1,4 \%$} & \multicolumn{2}{c}{$2,8 \%$} \\
& $40 \%$ & $30 \%$ & $40 \%$ & $30 \%$ \\
\hline $\mathrm{ACl}$ & 31 & 35 & 51 & 56 \\
$\mathrm{CP}$ & 33 & 36 & 52 & 57 \\
Pilar & 37 & 39 & 57 & 60 \\
\hline
\end{tabular}


Tabela 6.8 - Tensão aos 91 dias na armadura (MPa).

\begin{tabular}{ccccccc}
\hline \multirow{2}{*}{$\begin{array}{c}\text { Taxa de } \\
\text { armadura }\end{array}$} & \multicolumn{4}{c}{ Tensão para 91 dias } \\
\cline { 2 - 7 } & \multicolumn{2}{c}{$\mathrm{ACl}$} & \multicolumn{2}{c}{ Pilar } & \multicolumn{2}{c}{$\mathrm{CP}$} \\
\cline { 2 - 7 } & $40 \%$ & $30 \%$ & $40 \%$ & $30 \%$ & $40 \%$ & $30 \%$ \\
\hline $1,4 \%$ & 227 & 191 & 270 & 220 & 241 & 199 \\
$2,8 \%$ & 191 & 161 & 215 & 175 & 197 & 163 \\
\hline
\end{tabular}

Tabela 6.9 - Tensão aos 91 dias no concreto (MPa).

\begin{tabular}{ccccccc}
\hline \multirow{2}{*}{$\begin{array}{c}\text { Taxa de } \\
\text { armadura }\end{array}$} & \multicolumn{6}{c}{ Tensão para 91 dias } \\
\cline { 2 - 7 } & \multicolumn{2}{c}{$\mathrm{ACl}$} & \multicolumn{2}{c}{ Pilar } & \multicolumn{2}{c}{$\mathrm{CP}$} \\
\cline { 2 - 7 } & $40 \%$ & $30 \%$ & $40 \%$ & $30 \%$ & $40 \%$ & $30 \%$ \\
\hline $1,4 \%$ & 7,2 & 5,2 & 6,6 & 4,8 & 7,0 & 5,1 \\
$2,8 \%$ & 5,1 & 3,5 & 4,5 & 3,2 & 5,0 & 3,5 \\
$0 \%$ & 10,5 & 8,03 & 10,5 & 8,03 & 10,5 & 8,03 \\
\hline
\end{tabular}

\subsection{Análises dos resultados experimentais e da simulação numérica}

Neste item é feita comparação e análise dos resultados de deformação por fluência e retração obtidos experimentalmente e àqueles provenientes da simulação numérica dos protótipos de pilares.

Como pode ser visto nos gráficos 6.13a, 6.13b, 6.14a, 6.14b, 6.15a e 6.15b, o modelo do $\mathrm{ACl}$ subestima tanto as deformações experimentais dos corpos de prova quanto dos protótipos de pilares, indicando sua ineficácia na previsão das deformações. Para 91 dias, a simulação numérica calibrada com resultados experimentais dos corpos de prova é capaz de prever as deformações por fluência e retração experimental dos corpos de prova, mas subestima as deformações dos protótipos de pilares. Isto ocorre, pois a previsão feita a partir dos corpos de prova são inferiores à do pilar sem armadura, conforme visto anteriormente.

É possível notar também que, apesar das curvas calibradas com os resultados experimentais do protótipo superestimarem as deformações por fluência e retração no início apresentando coeficiente de variação maior que das outras simulações 
(29\% - tabela 6.10) são capazes de prever as deformações experimentais aos 91 dias dos pilares estudados. Isto pode ser comprovado, comparando os resultados experimentais aos 91 dias de tensão e deformação apresentados no item 5.5.2 com os resultados da simulação numérica (item 6.4). A partir desta comparação é possível concluir que a simulação que melhor prevê tanto as tensões quanto as deformações aos 91 dias é àquela calibrada com os resultados experimentais dos pilares.

Provavelmente, as curvas calibradas com resultados experimentais superestimaram as deformações por fluência e retração, pois o modelo viscoelástico de Maxwell-Chain utilizado para representar a fluência no Diana não é capaz de reproduzir o comportamento do concreto ao longo do tempo. Haveria a necessidade da implementação no Diana de um modelo viscoelástico mais representativo do efeito da fluência como, por exemplo, o modelo viscoelástico de Boltzmann.

Tabela 6.10 - Coeficientes de variação $\omega_{B 3} \mathrm{e}^{\omega_{B 3, \text { all }}}$ para protótipos de pilares (\%).

\begin{tabular}{cccccc}
\hline \multirow{2}{*}{ Taxa de armadura } & \multicolumn{5}{c}{ Curva calibrada } \\
\cline { 2 - 6 } & Dados & Tensão & ACl & Pilar & CP \\
\cline { 3 - 6 } $1,4 \%$ & $40 \%$ & 23,4 & 22,5 & 18,5 \\
& \multirow{3}{*}{ Exp. Pilar } & $30 \%$ & 13,8 & 27,0 & 16,7 \\
& \multirow{2}{*}{$2,8 \%$} & $40 \%$ & 34,0 & 20,5 & 25,2 \\
& \multirow{2}{*}{ Exp. Pilar } & $30 \%$ & 32,4 & 20,3 & 24,9 \\
\hline \multirow{2}{*}{$0 \%$} & $30 \%$ & 19,4 & 16,6 & 15,1 \\
& \multirow{2}{*}{ Exp. CP } & $40 \%$ & 45,3 & 33,7 & 39,5 \\
& \multirow{2}{*}{ Exp. Pilar } & $30 \%$ & 39,3 & 34,3 & 39,3 \\
\hline \multirow{3}{*}{ Exp. CP } & $30 \%$ & 27,1 & 28,1 & 19,7 \\
& & $40 \%$ & 16,3 & 44,0 & 21,4 \\
& & $30 \%$ & 14,4 & 41,7 & 20,2 \\
\hline
\end{tabular}




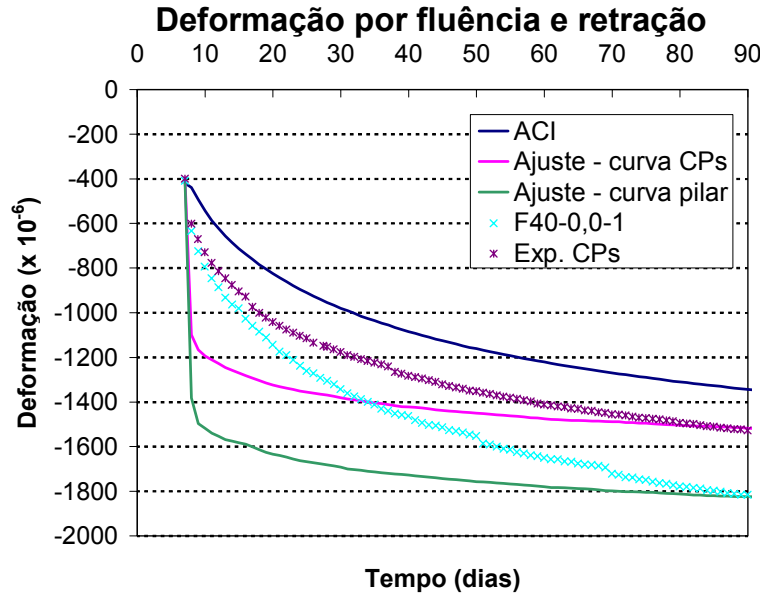

a) $40 \%$
Deformação por fluência e retração $\begin{array}{llllllllll}0 & 10 & 20 & 30 & 40 & 50 & 60 & 70 & 80 & 90\end{array}$

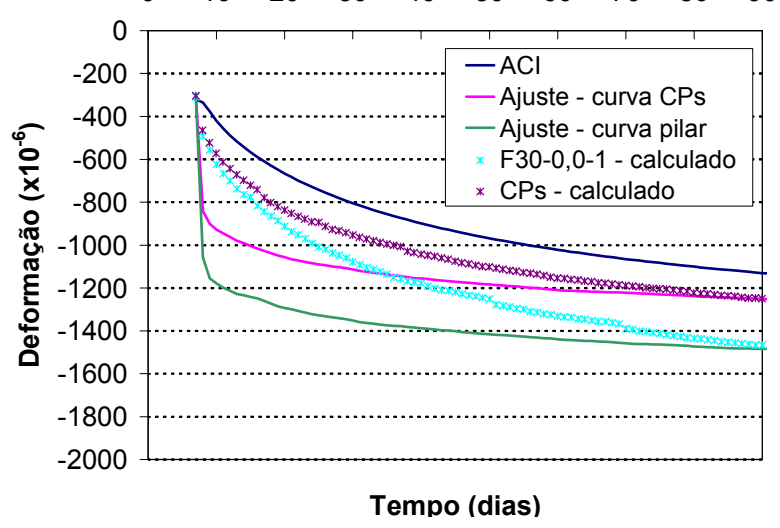

b) $30 \%$

Gráfico 6.13 - Deformação por fluência e retração do protótipo sem armadura $\left(\times 10^{-6}\right)$.

Deformação por fluência e retração

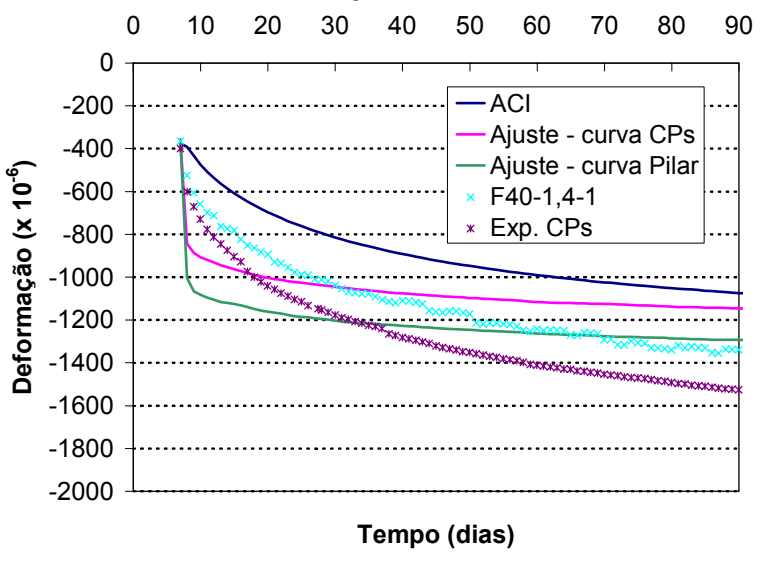

a) $40 \%$
Deformação por fluência e retração

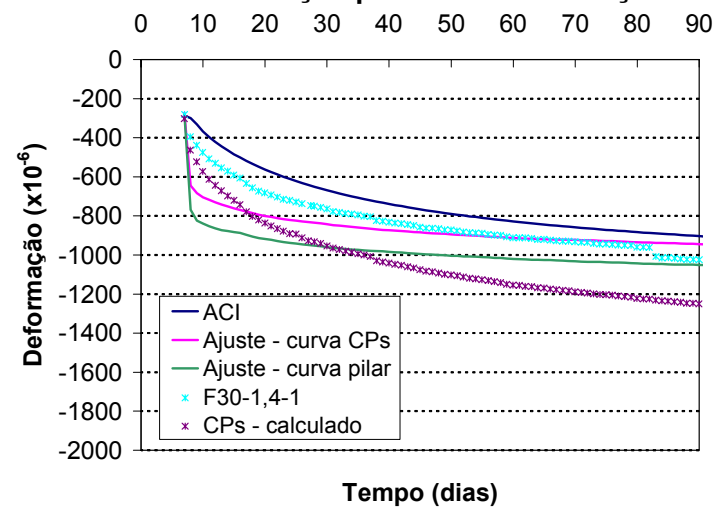

b) $30 \%$

Gráfico 6.14 - Deformação por fluência e retração do protótipo com taxa de armadura de 1,4\% $\left(\times 10^{-6}\right)$.

Deformação por fluência e retração

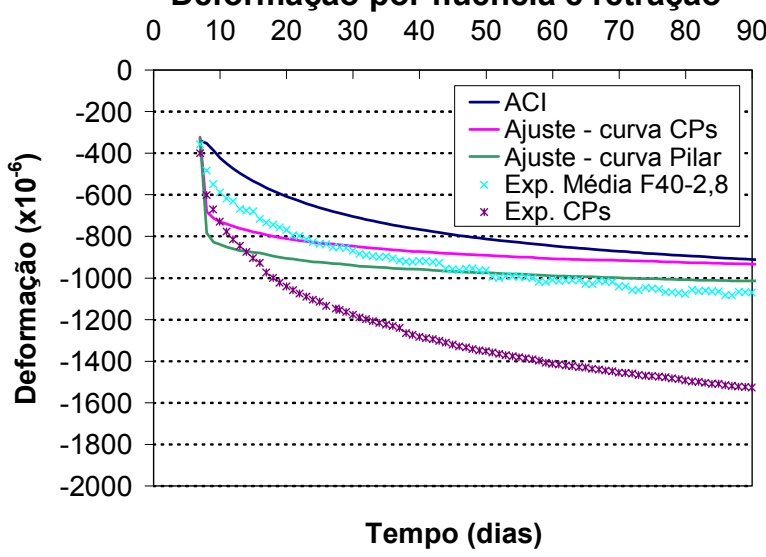

a) $40 \%$
Deformação por fluência e retração

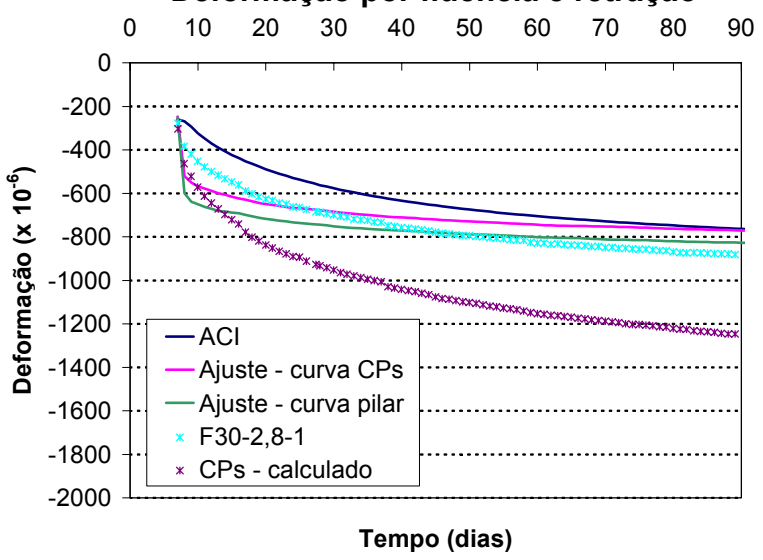

b) $30 \%$

Gráfico 6.15 - Deformação por fluência e retração do protótipo com taxa de armadura de 2,8\% $\left(\times 10^{-6}\right)$. 


\section{CAPÍTULO 7}

\section{RESULTADOS E ANÁlisES DA PREVISÃo DA FLUÊNCIA E RETRAÇÃO EM PILARES}

Este capítulo apresenta os resultados e análises obtidos dos modelos de previsão das tensões em pilares devido à fluência e retração a partir de resultados de corpos de prova (HOLM; PISTRANG, 1966). Também são apresentados os resultados e análises de modelos de previsão de fluência e retração em pilares a partir de resultados analíticos (ZIEHL; CLOYD; KREGER, 2004). Nestes modelos de previsão foi utilizado o coeficiente de geometria de $16 \%$. Este coeficiente foi determinado comparando o resultado experimental de deformação do pilar sem armadura (P40-0,0-1) com os corpos de prova conforme capítulo 5 . As análises são feitas para 91 dias.

Tabela 7.1 - Previsão da tensão no concreto aos 91 dias (MPa).

\begin{tabular}{cccccc}
\hline \multirow{2}{*}{ Tensão } & Taxa de & \multicolumn{2}{c}{ Tensão no concreto } & \multicolumn{2}{c}{ Tensão na armadura } \\
\cline { 3 - 6 } & armadura & $\begin{array}{c}\text { Holm; } \\
\text { Pistrang, 1966 }\end{array}$ & Experimental & $\begin{array}{c}\text { Holm; } \\
\text { Pistrang, 1966 }\end{array}$ & Experimental \\
\hline \multirow{2}{*}{$40 \%$} & $2,8 \%$ & 4,7 & 4,6 & 214,2 & 225,1 \\
& $1,4 \%$ & 6,6 & 6,7 & 288,4 & 282,5 \\
\multirow{2}{*}{$30 \%$} & $2,8 \%$ & 3,0 & 3,2 & 181,6 & 185,0 \\
& $1,4 \%$ & 4,6 & 5,1 & 252,0 & 215,5 \\
\hline
\end{tabular}

A partir dos resultados obtidos utilizando o modelo de Holm e Pistrang (1966) (tabela 7.1), é possível notar que as tensões tanto no concreto quanto da armadura previstas estão muito próximas das tensões experimentais. Holm e Pistrang (1966) também obtiveram resultados adequados utilizando esta previsão. A eficácia da previsão aos 91 dias somente foi possível devido o ajuste feito com o coeficiente de geometria que leva em consideração a diferença entre a geometria dos corpos de prova e dos protótipos de pilares. Apesar de ser um método simplificado, demonstra a necessidade de considerar nos modelos de previsão um coeficiente mais eficiente que leve em consideração a geometria dos elementos. Isto permitirá que a caracterização das propriedades de fluência e retração realizada em corpos de prova possa representar elementos com outras geometrias, assim como os 
resultados dos corpos de prova possam ser utilizados para calibração de modelos de modo mais preciso na previsão das deformações.

Conforme descrito no capítulo 2, o modelo de Ziehl; Cloyd e Kreger (2004) não utilizam resultados experimentais. Embora esta previsão seja feita utilizando o coeficiente de fluência e a deformação de retração previstos pelo modelo do ACl209R (1992), nesta pesquisa são empregados os modelos do $A C l, B 3, E C 2, G L$ e NBR, descritos no capítulo 2. Os resultados obtidos para 91 dias estão apresentados na tabela 6.12 .

Tabela 7.2 - Previsão da deformação no concreto aos 91 dias pelo modelo de Ziehl; Cloyd e Kreger (2004) $\left(\times 10^{-6}\right)$.

\begin{tabular}{ccccccc}
\hline \multirow{2}{*}{ Modelo } & Coeficiente & \multicolumn{2}{c}{ Deformação por } & \multicolumn{2}{c}{$40 \%$} & \multicolumn{2}{c}{$30 \%$} \\
& de fluência & retração $\left(\times 10^{-6}\right)$ & $1,4 \%$ & $2,8 \%$ & $1,4 \%$ & $2,8 \%$ \\
\hline $\mathrm{ACl}$ & 1,31 & 409 & 1056 & 882 & 884 & 738 \\
$\mathrm{~B} 3$ & 2,00 & 378 & 1177 & 947 & 967 & 777 \\
$\mathrm{EC} 2$ & 2,25 & 270 & 1147 & 912 & 924 & 734 \\
$\mathrm{GL}$ & 2,26 & 417 & 1257 & 998 & 1034 & 820 \\
$\mathrm{NBR}$ & 2,75 & 222 & 1208 & 940 & 961 & 747 \\
Experimental & 2,24 & 389 & 1345 & 1049 & 1028 & 885 \\
\hline
\end{tabular}

A partir dos resultados obtidos, é possível concluir que, as previsões dos coeficientes de fluência dos modelos analisados subestimam aqueles obtidos experimentalmente e, conseqüentemente, a previsão da deformação do concreto dos pilares também é subestimada, como pode ser visto na tabela 7.2. Para Ziehl; Cloyd e Kreger (2004) o modelo de previsão do ACI209R (1992) concordou de forma razoável com os resultados experimentais. Portanto, nesta pesquisa, considera-se importante que haja um modelo de previsão principalmente de fluência que seja capaz de estimar esta propriedade e, conseqüentemente, prever as deformações do concreto nos pilares analisados. Acredita-se que não há necessidade de ajuste das deformações por retração, pois os resultados experimentais e teóricos foram muito próximos.

Neste sentido, no item 7.1 foi calibrado o modelo de fluência do B3 utilizando resultados experimentais obtidos da caracterização da fluência em corpos de prova do Traço II. 


\subsection{Calibração do modelo de fluência B3}

Considerando que o B3 é um dos modelos que melhor se ajustou à curva de fluência específica do Traço II utilizado nos pilares (coeficiente de variação $\omega_{B 3}=$ $12,6 \%$ ) e constitui um método que é utilizado para análise de estruturas que exigem grande precisão da previsão (BAŽANT, 2001), este modelo foi escolhido para calibração com os resultados experimentais.

A calibração foi feita de acordo com o capítulo 2 utilizando os resultados de fluência dos corpos de prova do Traço II para 91 dias. Este método gerou parâmetros ajustados às características dos materiais estudados $p_{1}$ e $p_{2} \mathrm{e}$, conseqüentemente, uma função de fluência expressa pela eq.(7-1). Como pode ser visto no gráfico 7.1 , a curva calibrada se ajustou aos resultados experimentais durante o período medido. Entretanto, ainda há erro relacionado à deformação nos primeiros 17 dias.

$J\left(t, t^{\prime}\right)=p_{1}+p_{2} F\left(t, t^{\prime}\right)$

$F\left(t, t^{\prime}\right)=C_{0}\left(t, t^{\prime}\right)+C_{d}\left(t, t^{\prime}, t_{0}\right)$

$J\left(t, t^{\prime}\right)=12,79 \cdot 10^{-6}+1,22 \cdot F\left(t, t^{\prime}\right)$

$J\left(t, t^{\prime}\right)$ - fluência específica ajustada ( $\left.\times 10^{-6} / \mathrm{MPa}\right)$

$p_{1}, p_{2}$ - parâmetros dependentes das características dos materiais

$F\left(t, t^{\prime}\right)$ - fluência específica básica e de secagem (x10-6/MPa)

$C_{0}\left(t, t^{\prime}\right)$ - fluência especifica básica ( $\left.\times 10^{-6} / \mathrm{MPa}\right)$

$C_{d}\left(t, t^{\prime}\right)$ - fluência específica de secagem (x10-6/MPa) 


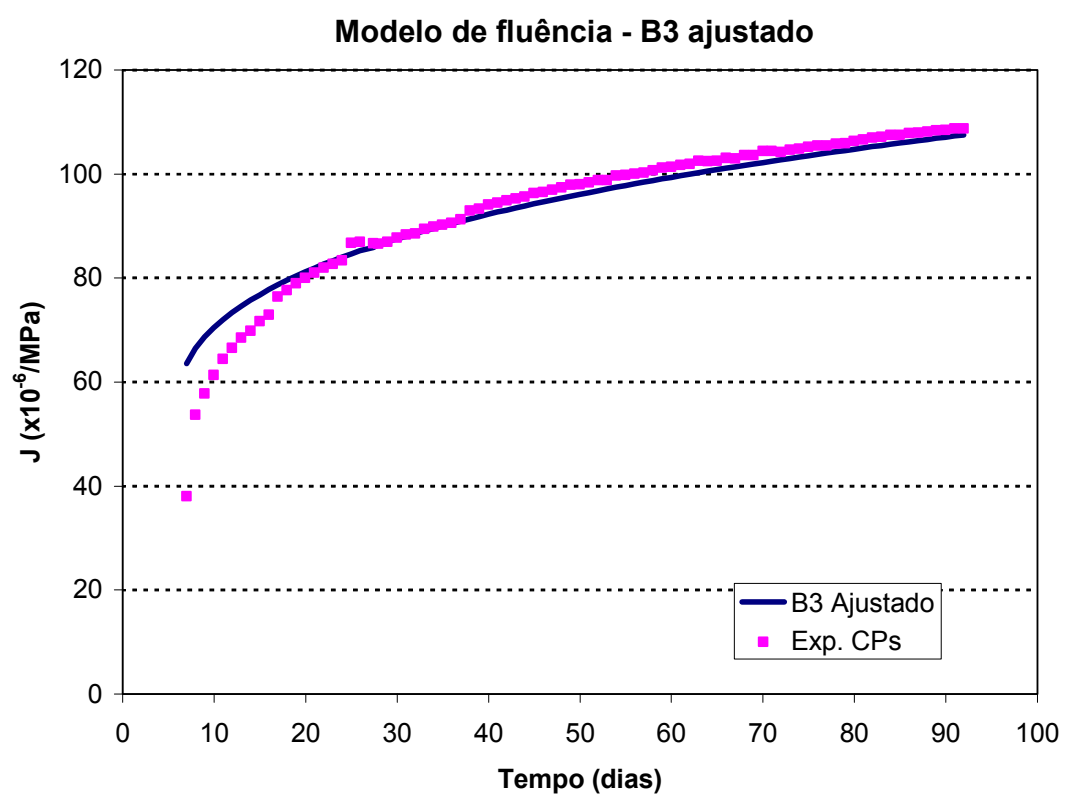

Gráfico 7.1 - Fluência específica calibrada do modelo B3.

A partir do modelo calibrado foi determinado o coeficiente de fluência de 2,21. Comparando o coeficiente do modelo proposto com os obtidos experimentalmente mostrados na tabela 7.2, é possível notar que este também subestima o coeficiente de fluência experimental dos pilares. Entretanto, como o modelo é calibrado a partir de resultados experimentais dos corpos de prova, é possível ajustar este coeficiente de fluência com o coeficiente de geometria obtido experimentalmente de $16 \%$, que leva em conta o efeito da geometria entre corpos de prova e pilares. Este ajuste não pode ser feito diretamente nos coeficientes de fluência obtidos dos modelos da tabela 7.2, pois teoricamente são previsões que já consideram o efeito da geometria distinta entre protótipos de pilares e corpos de prova. Entretanto, os modelos de previsão de fluência consideram que não há efeito da geometria entre corpos de prova e protótipos de pilares estudados nesta pesquisa, pois as relações da formulação que levam em consideração a geometria destes modelos são iguais $\left(\mathrm{V} / \mathrm{S}=\mathrm{A}_{\mathrm{d}} / \mathrm{u}=3,75\right)$ e, conseqüentemente, as previsões dos coeficientes de fluência são iguais para ambos os elementos.

Como a previsão do modelo B3 da deformação por retração foi muito próxima da experimental, o modelo de retração não foi calibrado com os resultados experimentais de retração. Além disso, Videla; Covarrubias e Masana (2004) afirmam que a retração última parece ser independente das dimensões dos corpos de prova, fato que não justificaria a calibração do modelo para verificação do efeito 
da geometria. Portanto, foram utilizados os resultados de retração obtidos do modelo B3.

Nos gráficos 7.2 e 7.3 é possível notar que a previsão das deformações ao longo do tempo dos protótipos, utilizando o modelo de fluência do B3 ajustado e o coeficiente de geometria, foi eficaz. Entretanto, como o ajuste do modelo de fluência do B3 não conseguiu prever a deformação nos primeiros dias, há um erro atribuído no início das previsões. As deformações previstas para 91 dias, mostradas na tabela 7.3, demonstram que a calibração forneceu resultados adequados e capazes de prever as deformações experimentais.

Tabela 7.3 - Deformação no concreto aos 91 dias pelo modelo de Ziehl; Cloyd e Kreger (2004) ajustado $\left(\times 10^{-6}\right)$.

\begin{tabular}{ccccc}
\hline \multirow{2}{*}{ Modelo } & \multicolumn{2}{c}{$40 \%$} & \multicolumn{2}{c}{$30 \%$} \\
& $1,4 \%$ & $2,8 \%$ & $1,4 \%$ & $2,8 \%$ \\
\hline B3 Ajustado & 1329 & 1041 & 1090 & 854 \\
Experimental & 1345 & 1049 & 1028 & 885 \\
\hline
\end{tabular}

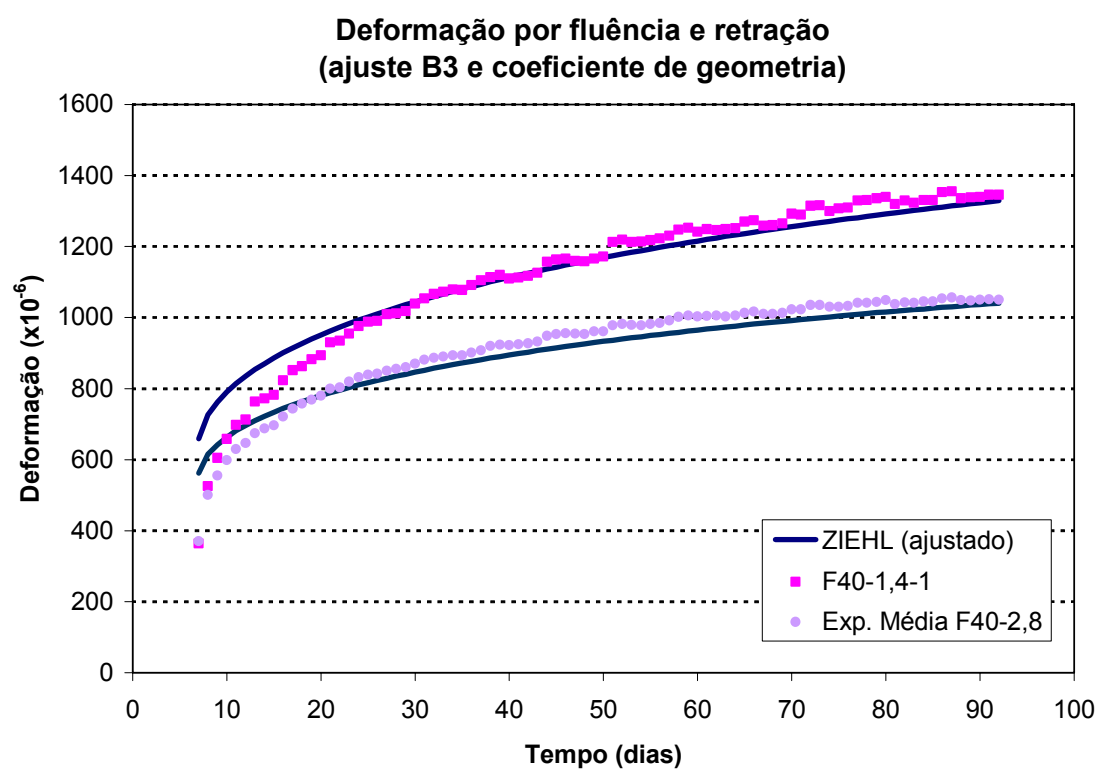

Gráfico 7.2 - Deformação por fluência e retração considerando ajuste do modelo B3 e do coeficiente de geometria para tensão de $40 \%\left(\times 10^{-6}\right)$. 


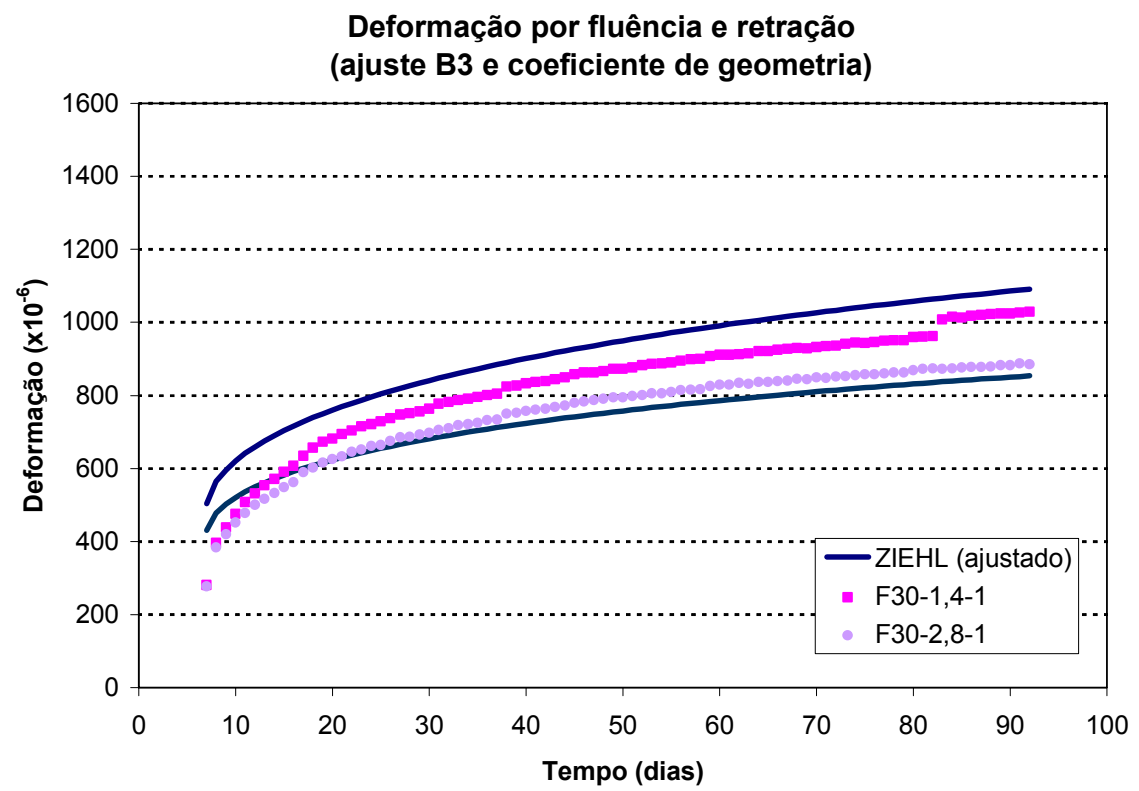

Gráfico 7.3 - Deformação por fluência e retração considerando ajuste do modelo B3 e do coeficiente de geometria para tensão de $30 \%\left(\times 10^{-6}\right)$.

É também interessante observar no gráfico 7.4 que, utilizando o modelo ajustado do B3 para prever a fluência específica até 365 dias, pode-se notar que o modelo considera um aumento significativo das deformações no período de 91 a 365 dias $(\approx 21 \%)$. Este aumento reforça a necessidade da realização de ensaios por um período superior a 91 dias para verificação do desenvolvimento das deformações ao longo do tempo e, conseqüentemente, a validação do modelo calibrado.

Vale ressaltar que segundo Neville, 1983 a imprecisão da previsão ao longo do tempo feita a partir de ajuste de resultados experimentais medidos até 91 dias é de aproximadamente $13 \%$. Isto implica que no tempo infinito as deformações teoricamente devem ser multiplicadas por um coeficiente de 1,13. 


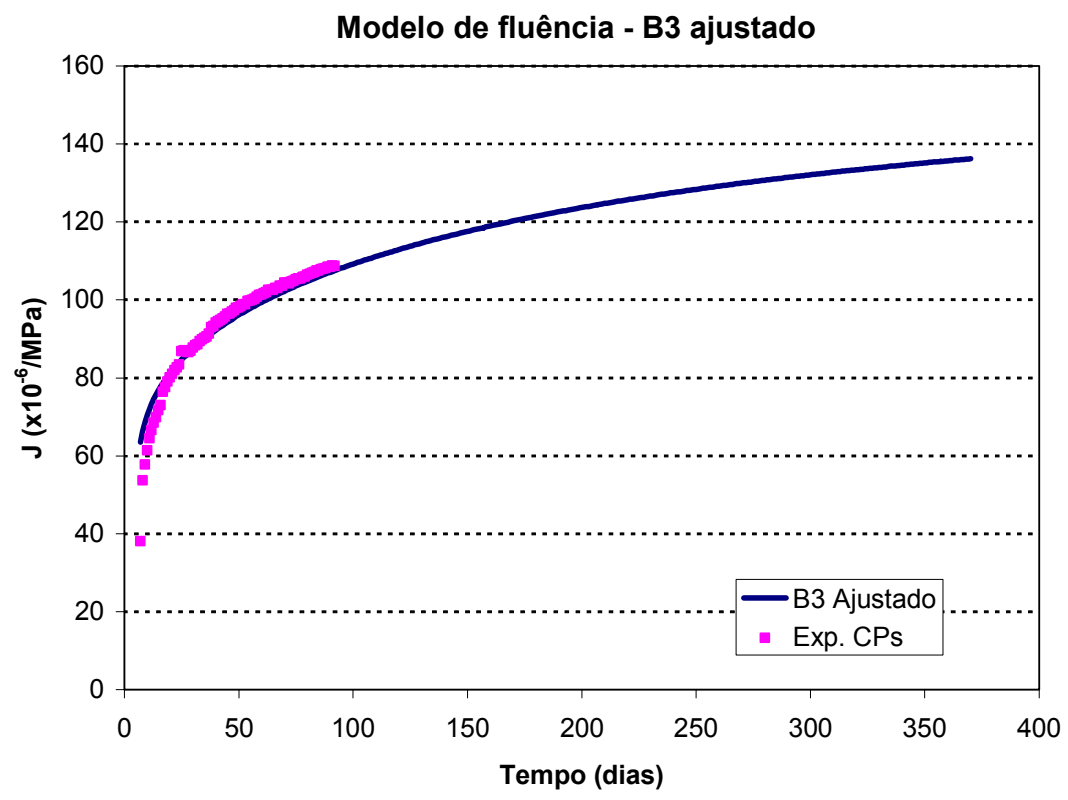

Gráfico 7.4 - Fluência específica calibrada do modelo B3 estendido. 


\section{CAPÍTULO 8}

\section{CONCLUSÕES E TRABALHOS FUTUROS}

Apesar da fluência e retração serem propriedades muito estudadas, a necessidade de verificação dos modelos de previsão devido o surgimento de novos materiais, assim como a caracterização destes materiais tem reforçado 0 melhor entendimento do comportamento da deformabilidade do concreto ao longo do tempo.

Neste sentido esta pesquisa forneceu resultados fundamentais de caracterização destas propriedades e indicadores estatísticos que apontam os melhores modelos de previsão. Além disso, foi feita uma investigação (teórica e experimental) das deformações ao longo do tempo em protótipos de pilares de concreto armado visando um melhor entendimento da redistribuição das tensões do concreto para armadura considerando duas taxas de armadura. Finalmente, um modelo de fluência ajustado aos resultados experimentais é sugerido para o concreto utilizado na previsão das deformações dos protótipos. Este ajuste demonstrou ser eficaz para as previsões das deformações.

Neste item, são apresentadas as observações e conclusões das principais atividades desenvolvidas nesta pesquisa.

\subsection{Análise paramétrica}

A partir da análise paramétrica, que avaliou a sensibilidade dos modelos de previsão de fluência e retração em relação aos parâmetros de entrada, pode ser observado que:

- A verificação da sensibilidade dos modelos com relação aos parâmetros individuais permitiu analisar os modelos de previsão de fluência e retração, assim como avaliar as variáveis que mais influem em cada modelo e controlar em laboratório os parâmetros que sofrem maiores alterações; 
- Para a fluência, entre os modelos e traços comparados, a umidade relativa é o fator mais influente. As maiores diferenças ocorrem no modelo B3 e as menores diferenças são as do modelo $\mathrm{ACl}$. Na retração todos os modelos também são bastante influenciados por este parâmetro. O modelo do EC2 é o que apresenta maior alteração, enquanto que o modelo do $\mathrm{ACl}$ demonstrou menor mudança das deformações;

- Com relação à temperatura, nenhum modelo demonstra influência deste parâmetro, embora, a variação temperatura deva ser um fator influente nas deformações obtidas experimentalmente;

- Na fluência, considerando o tipo de cimento, o único modelo que apresenta mudança significativa a este parâmetro é o da NBR. Enquanto que, na retração, somente o modelo do EC2 é influenciado pelo tipo de cimento;

- Alterando a classe de resistência, na fluência, todos os modelos demonstraram mudanças, sendo que o modelo do EC2 apresentou maior influência deste parâmetro. Na retração, somente os modelos do EC2 e do GL apresentam alteração em relação à classe de resistência, sendo o modelo do EC2 o que apresenta maior influência deste parâmetro. Portanto, como na fluência a resistência à compressão alterou as deformações em todos os modelos, foram estudadas nesta pesquisa classes distintas de concreto. Para retração, apesar de terem sido verificadas mudanças nas deformações apenas nos modelos do EC2 e do GL, é fundamental analisar classes de resistências distintas, pois diversas relações água cimento influenciam diretamente na retração;

- O modelo do ACl apresenta as menores deformações ao longo do tempo para fluência, subestimando os modelos restantes. Enquanto que as curvas de deformação por fluência do modelo da NBR apresentam, para mesmas condições, os maiores resultados. A diferença relativa da fluência específica dos modelos da NBR e do ACl são de aproximadamente $20 \%$, aumentando ao longo do tempo até $50 \%$ aos 900 dias. Na retração, o modelo da NBR apresenta as menores deformações ao longo do tempo quando comparado com os demais modelos. Os modelos B3 e GL apresentam as maiores deformações aos 900 dias. 


\subsection{Fluência e retração dos corpos de prova}

A partir da caracterização da fluência básica e por secagem dos traços estudados e análise da eficiência dos modelos teóricos a estas propriedades observaram-se que:

- Apesar da taxa de crescimento da resistência média à compressão do concreto após 28 dias dos traços analisados não ser expressiva, observa-se que a fluência por secagem apresenta taxa de crescimento considerável. Este fato demonstra a importância da realização do ensaio de fluência por secagem por um período superior a 91 dias;

- A classe de resistência afeta a fluência específica de maneira considerável. Os traços com maior resistência à compressão apresentaram fluência específica menores;

- Levando em conta os traços analisados, os modelos do $\mathrm{ACl}\left(\omega_{B 3, a l l}=13,7 \%\right)$ e EC2 $\left(\omega_{B 3, \text { all }}=14,6 \%\right)$ podem ser considerados os mais eficazes para prever a fluência por secagem. A norma brasileira superestima $\left(\omega_{B 3, a l l}=32 \%\right)$ a fluência por secagem;

- Para fluência básica também são considerados eficazes os modelos do ACl $\left(\omega_{B 3, \text { all }}=8,2 \%\right)$ e do EC2 $\left(\omega_{\text {B3,all }}=10,7 \%\right)$;

- Apesar de ser adotado um coeficiente de variação considerado eficaz para avaliação dos modelos analisados, é importante que o modelo represente a curva experimental com maior precisão possível. De acordo com o ACl209R (1992) Committee apud Videla (2006) não há um indicador estatístico disponível adequado para comparação, mas existem coeficientes de variação que são os indicadores mais aceitos para fins comparativos. Portanto, é fundamental o ajuste do modelo que melhor prevê as deformações com a curva experimental que descreve as características do material utilizado.

A caracterização da retração por secagem e comparação deste ensaio com os modelos teóricos forneceram as seguintes observações: 
- Considerando os traços analisados, o período de 91 dias é suficiente para avaliar as deformações de retração por secagem, pois praticamente não há crescimento das deformações;

- Não há variação significativa das deformações por retração medidas considerando diferentes classes de resistência, confirmando que em concretos de mesma trabalhabilidade a retração não é alterada pelo aumento do teor de cimento;

- O modelo da NBR, apesar de ser utilizado para previsão das deformações dos concretos brasileiros, subestima os resultados experimentais para os traços estudados $\left(\omega_{B 3, \text { all }}=52,8 \%\right)$;

- $O$ modelo do $\mathrm{ACl}\left(\omega_{B 3, \text { all }}=26,9 \%\right)$ e $\circ \mathrm{GL}\left(\omega_{B 3, \text { all }}=26,6 \%\right)$ são os que melhores representam os resultados experimentais medidos no período analisado;

- Comparando os resultados experimentais com o modelo do EC2, pode-se notar que este modelo subestima exageradamente $\left(\omega_{B 3, a l l}=76,5 \%\right)$ os resultados experimentais;

- Considerando os traços analisados, o B3 ( $\left.\omega_{B 3, a l l}=42,5 \%\right)$ não é capaz de prever as deformações dos traços analisados, ora superestimando ora subestimando os resultados experimentais.

\subsection{Protótipos de pilares em concreto armado}

A partir dos resultados experimentais obtidos das deformações nas armaduras e no concreto dos protótipos de pilares foi observado que:

- Apesar de serem tomadas precauções para centralização da carga, não foi possível obter compressão simples como desejado. Portanto, foram adotadas as médias das deformações de cada pilar;

- Como já era esperado, a média de deformação das armaduras aos 91 dias foi muito semelhante á deformação do concreto; 
- A maior parte das deformações por fluência e retração dos protótipos ocorreram nas primeiras 4 semanas, período que o concreto apresentou baixa resistência à compressão;

- As maiores deformações foram observadas no pilar sem armadura. Considerando o pilar armado, tanto o concreto quanto a armadura apresentaram as maiores deformações nos pilares com menor taxa de armadura;

- Não foi verificado escoamento das armaduras, mesmo nos pilares com menor taxa de armadura;

- A taxa de crescimento de deformação por retração dos pilares com taxas de armadura de $2,8 \%$ e $1,4 \%$ é praticamente a mesma até 4 semanas. Após este período a taxa de crescimento é maior para os pilares com menor taxa de armadura;

- Foi confirmada a linearidade entre tensão e deformação. Isto foi verificado nos protótipos de pilares carregados a 30 e $40 \%$ de tensão;

- Em média, as taxas de armadura de 2,8 e 1,4\% restringiram 41 e $28 \%$ às deformações no concreto até 91 dias, respectivamente;

- A relação volume superfície (V/S) utilizada nos modelos do ACl, B3 e GL e a relação da área de concreto da seção transversal pelo perímetro da seção transversal $\left(A_{c} / \mathrm{u}\right)$ utilizada nos modelo do $E C 2$ e da NBR não representou o efeito da geometria utilizada nesta pesquisa. Apesar de ambos, pilar e corpo de prova, possuírem mesma relação, não apresentaram deformação semelhantes. Para 91 dias, o coeficiente de geometria do pilar foi de $16 \%$ em relação aos corpos de prova;

- Como era esperado, apesar dos corpos de prova apresentarem deformação inferior a dos protótipos sem armadura, estes superestimam as deformações dos pilares em concreto armado. Isso ocorre devido à restrição da armadura existente nestes elementos estruturais.

A partir dos resultados da simulação numérica dos protótipos de pilares é possível concluir que:

- O programa de elementos finitos Diana foi capaz de representar o estudo de transferência de carregamento nos pilares analisados nesta pesquisa para 
91 dias. Este programa demonstra ser uma ferramenta importante para previsão das deformações ao longo do tempo, embora haja a simulação superestime as deformações no início da previsão. Provavelmente, as curvas calibradas com resultados experimentais superestimaram as deformações por fluência e retração, pois o modelo viscoelástico de Maxwell-Chain utilizado para representar a fluência no Diana não é capaz de reproduzir o comportamento do concreto ao longo do tempo. Haveria a necessidade da implementação no Diana de um modelo viscoelástico mais representativo do efeito da fluência;

- As simulações que utilizaram o modelo do $\mathrm{ACl}$ disponível no Diana subestimaram as deformações experimentais, demonstrando que 0 modelo não é capaz de prever as deformações;

- As simulações calibradas com a curva experimental dos corpos de prova não foram capazes de prever as deformações dos protótipos de pilares, principalmente submetidos à tensão de $40 \%$. Como as simulações com tensão a $30 \%$ foram muito próximas, a calibração com a curva dos corpos de prova também se aproximou dos resultados experimentais;

- Apesar da curva calibrada com os resultados experimentais do pilar sem armadura superestimar as deformações por fluência e retração no início da previsão, aos 91 dias é capaz de prever as tensões e deformações experimentais dos protótipos com ambas as taxas de armadura, 1,4 e $2,8 \%$.

A partir da previsão da fluência e retração em pilares utilizando modelos que levam em consideração tanto resultados experimentais de corpos de prova quanto de modelos de previsão de fluência e retração são observadas as seguintes conclusões:

- Cabe enfatizar que os modelos de previsão de fluência e retração em pilares, adotados nesta pesquisa, apresentam em sua formulação uma simplificação que considera os resultados de corpos de prova para prever o comportamento ao longo do tempo de protótipos de pilares. Apesar desta simplificação, os resultados obtidos demonstram a necessidade dos modelos de previsão de fluência adotarem um coeficiente mais eficiente que leve em consideração a geometria do elemento analisado; 
- O modelo de Holm e Pistrang (1966) foi capaz de prever as tensões aos 91 dias a partir de resultados experimentais de corpos de prova ajustados com o coeficiente de geometria;

- Utilizando o coeficiente de fluência dos modelos do ACl, B3, EC2, GL e NBR na previsão proposta por Ziehl; Cloyd e Kreger (2004), não foi possível prever as deformações dos protótipos desta pesquisa;

- A calibração do modelo B3 com os resultados experimentais dos corpos de prova permitiu a obtenção de um coeficiente de fluência que, ajustado com o coeficiente de geometria, foi capaz de prever as deformações propostas por Ziehl; Cloyd e Kreger (2004) para os protótipos de pilares estudados nesta pesquisa.

\subsection{Sugestões para trabalhos futuros}

Apesar da fluência e retração do concreto serem propriedades amplamente estudadas, importantes avanços têm sido alcançados nos últimos anos, e algumas sugestões são feitas para pesquisas futuras no campo de fluência e retração de protótipo de pilares e corpos de prova:

- Padronizar os ensaios de fluência (condições de ensaio - umidade relativa e temperatura e dimensões de corpos de prova) e retração (dimensões de corpos de prova). A padronização das condições de ensaio permite que resultados provenientes de diferentes concretos possam ser comparados;

- Realizar um volume maior de ensaios em corpos de prova tanto em concreto convencional quanto em concretos especiais (auto-adensável, alto desempenho) com o objetivo de caracterizar a fluência e retração de concretos brasileiros. Para concretos convencionais caracterizar principalmente a propriedade de fluência por secagem. Isto permitirá montar, juntamente com os resultados existentes e obtidos nesta pesquisa, um banco de dados. Além disso, é possível calibrar um modelo de previsão padronizado que represente uma gama grande de concretos; 
- Estender por um período acima de 91 dias os ensaios de fluência por secagem e verificar se a calibração utilizando resultados de 91 dias é capaz de prever resultados para idades superiores;

- Realizar ensaios com outras geometrias de pilares, estabelecendo coeficientes mais precisos que levem em consideração em modelos de previsão o efeito da geometria entre distintos elementos. 


\section{REFERÊNCIAS}

ASSOCIAÇÃO BRASILEIRA DE NORMAS TÉCNICAS. NBR7480: Aço destinado à armaduras para estruturas de concreto armado - Método de Ensaio. Rio de Janeiro, 2008.

ASSOCIAÇÃO BRASILEIRA DE NORMAS TÉCNICAS. NBRNM248: Agregados Determinação da composição granulométrica - Método de Ensaio. Rio de Janeiro, 2003.

ASSOCIAÇÃO BRASILEIRA DE NORMAS TÉCNICAS. NBRNM46: Agregados Determinação do material fino que passa através da peneira 75 micrometro, por lavagem - Método de Ensaio. Rio de Janeiro, 2003.

ASSOCIAÇÃO BRASILEIRA DE NORMAS TÉCNICAS. NBRNM52: Agregado miúdo - Determinação da massa específica e massa específica aparente - Método de Ensaio. Rio de Janeiro, 2003.

ASSOCIAÇÃO BRASILEIRA DE NORMAS TÉCNICAS. NBR7222: Argamassa e concreto - Determinação da resistência à tração por compressão diametral de corpos-de-prova cilíndricos - Método de Ensaio. Rio de Janeiro, 1994.

ASSOCIAÇÃO BRASILEIRA DE NORMAS TÉCNICAS. NBRNM131: Concreto endurecido - Determinação da retração hidráulica ou higrométrica do concreto Método de Ensaio. Rio de Janeiro, 1998.

ASSOCIAÇÃO BRASILEIRA DE NORMAS TÉCNICAS. NBRNM67: Concreto Determinação da consistência pelo abatimento do tronco de cone - Método de Ensaio. Rio de Janeiro, 1998.

ASSOCIAÇÃO BRASILEIRA DE NORMAS TÉCNICAS. NBR8522: Concreto Determinação do módulo de deformação estático e diagrama tensão-deformação. Rio de Janeiro, 2003.

ASSOCIAÇÃO BRASILEIRA DE NORMAS TÉCNICAS. NBRNM47: Concreto Determinação do teor de ar em concreto fresco - Método pressiométrico - Método de Ensaio. Rio de Janeiro, 2002. 
ASSOCIAÇÃO BRASILEIRA DE NORMAS TÉCNICAS. NBR8224: Determinação da fluência - Método de Ensaio. Rio de Janeiro, 1983.

ASSOCIAÇÃO BRASILEIRA DE NORMAS TÉCNICAS. NBR5739: Ensaio de compressão de corpos de prova de concreto cilíndricos - Método de Ensaio. Rio de Janeiro, 1994.

ASSOCIAÇÃO BRASILEIRA DE NORMAS TÉCNICAS. NBR5738: Moldagem e cura de corpos de prova de concreto, cilíndricos ou prismáticos - Método de Ensaio. Rio de Janeiro, 2003.

ASSOCIAÇÃO BRASILEIRA DE NORMAS TÉCNICAS. NBR6118: Projeto de estruturas de concreto - Procedimento. Rio de Janeiro, 2003.

ASSOCIAÇÃO BRASILEIRA DE NORMAS TÉCNICAS. NBR6118: Projeto de estruturas de concreto - Procedimento. Rio de Janeiro, 2004.

ASSOCIAÇÃO BRASILEIRA DE NORMAS TÉCNICAS. NBR6118: Projeto de estruturas de concreto - Procedimento. Rio de Janeiro, 2002.

ACKER, P., ULM, F. Creep and shrinkage of concrete: physical origins and practical measurements. Nuclear Engineering and Design, p. 143-158, May, 2000.

ADORNO, A. L. C. Análise teórica e experimental de pilares em concreto simples e armado sob flexo-compressão reta. 2004. 399 p. Tese (Doutorado) Universidade de Brasília, Estruturas e Construção Civil, Brasília, 2004.

AL-MANASSEER, A., LAM, J. P. Statistical evaluation of shrinkage and creep models. ACI Materials Journal, p. 170-176, May-June, 2005.

AL-MANASSEER, A.; MASOOD, H. Sensitivity of the models for predicting creep of concrete. In: 8TH INTERNATIONAL CONFERENCE ON CREEP, SHRINKAGE AND DURABILITY OF CONCRETE AND CONCRETE STRUCTURES, 2008, Japan, v.2, p. 1385-1396.

ALMEIDA, L. C. Identificação de parâmetros estruturais com emprego de análise inversa. 2006. 192 p. Tese (Doutorado) - Faculdade de Engenharia Civil, Arquitetura e Urbanismo da Universidade Estadual de Campinas, Campinas, 2006. 
AL-SALEH, S. A; AL-ZAID, R. Z. Effects of drying conditions, admixtures and specimen size on shrinkage strains. Cement and Concrete Research, n. 36, November, 2004.

AMERICAN CONCRETE INSTITUTE. ACI209-82: Prediction of creep, shrinkage, and temperature effects in concrete structures, 1982.

AMERICAN CONCRETE INSTITUTE. ACI209R-92: Prediction of creep, shrinkage, and temperature effects in concrete structures, 1992.

AMERICAN CONCRETE INSTITUTE. ACI209R-92: Prediction of creep, shrinkage, and temperature effects in concrete structures, 2008.

AMERICAN SOCIETY FOR TESTING AND MATERIALS. ASTMC490: Standard practice for use of apparatus for determination of length change of hardened cement paste, mortar, and concrete. Annual Book of ASTM Standards, Philadelphia, 1997.

AMERICAN CONCRETE INSTITUTE. ACI318-05: Buildind code requirements for structural concrete, 2005.

AMERICAN CONCRETE INSTITUTE. ACI318-05: Buildind code requirements for structural concrete, 2003.

ARAÚJO, L. M. B. A. Análise teórico-experimental de pilares de concreto submetidos à flexão normal composta. 2004. 196 p. Dissertação (Mestrado). Universidade Federal de Goiás, Goiás, 2004.

ASSIS, W. A. Sistemas computacionais de apoio à monitoração de estruturas de engenharia civil. 2007265 p. Tese (Doutorado) - Escola Politécnica, Universidade de São Paulo, São Paulo, 2007.

ATIS C. D.; BILIM C.; CELIK O.; KARAHAN O. Influence of activator on the strength and drying shrinkage of alkali-activated slag mortar. Construction and Building Materials, n. 23, November, 2007.

BAZANT, Z.P.; WITTMANN, F. H.; KIM, JENN-KEUN; ALOU, F. Statistical extrapolation of shrinkage data - Part I: Regression, ACI Materials Journal, p. 2034, 1987. 
BAŽANT, Z.P., Hauggaard, A. B., Baweja, S.; Ulm, F. Microprestress-solidification theory for concrete creep. Journal of Engineering Mechanics, p. 1188-1194, 1997.

BAŽANT, Z.P., BAWEJA, S., Creep and shrinkage prediction model for analysis and design of concrete structures (Model B3), In: ADAM NEVILLE SYMPOSIUM: CREEP AND SHRINKAGE OF CONCRETE - STRUCTURAL AND DESIGN EFFECTS, ACI SPECIAL PUBLICATION SP194, Michigan, USA: Farmington Hills, 2000, p.1-73.

BAŽANT, Z. P., Prediction of concrete creep and shrinkage: past, present and future. Nuclear Engineering and Design, p. 27-38, 2001.

BAŽANT, Z. P.; LI, G. Comprehensive Database on Concrete Creep and Shrinkage. ACI Materials Journal, p. 635-637, November-December, 2008.

BAŽANT, Z. P; LI, G.; YU, Q. Prediction of creep and shrinkage and their effects in the concrete structures: Critical appraisal. In: 8TH INTERNATIONAL CONFERENCE ON CREEP, SHRINKAGE AND DURABILITY OF CONCRETE AND CONCRETE STRUCTURES, Japan, v.2, 2008, p. 1275-1289.

CARREIRA, J. D.; BURG, R. G. Testing for Concrete Creep and Shrinkage. In: THE ADAM NEVILLE SYMPOSIUM: CREEP AND SHRINKAGE OF CONCRETE STRUCTURAL DESIGN EFFECTS, Michigan, USA: Farmington Hills, 2000, p.381420.

CASTRO, J.T.P; VIEIRA, R.D; SOUSA, R. A; MEGGIOLARO, M. A; FREIRE, J.L.F. Time-dependent Residual Stresses in Reinforced Concrete Columns. In: PROCEEDINGS OF THE XI INTERNATIONAL CONGRESS ON EXPERIMENTAL AND APPLIED MECHANICS. Orlando, USA: Bethlen, 2008.

COMITÉ EUROPÉEN DU bETÓN - fÉDÉRATION INTERNATIONAL DE LA pRÉCONTRAINTE. CEB Model Code 1990. Bulletin d'Information Lausanne, $n^{\circ}$ 203, Juin, 1991.

COSTA NETO, R. C. F. Estudo experimental sobre os efeitos da fluência do concreto em pilares esbeltos. 2004112 p. Dissertação (Mestrado) - Pontifícia Universidade Católica do Rio de Janeiro, Rio de Janeiro, 2004. 
CLAESON, C.; GYLLTOFT, K. Slender concrete subjected to sustained and shortterm eccentric loading. ACI Structural Journal, v. 97, n.1, p. 45-53, JanuaryFebruary, 2000.

CREUS G. J. Viscoelasticity - Basic theory and applications to concrete structures. Berlin: Spring, 1986.

DT600 User's Manual Disponível em: <www.datataker.com/products/dt600.html>. Acesso em: 15. Jun. 2009.

DAVIS, R. E.; DAVIS, H. E. Flow of Concrete Under the Action of Sustained Loads. Journal of the American Concrete Institute, v. 2, n. 7, Proceedings v. 27, p. 837, March, 1931.

EQUIPE DE FURNAS, LABORATÓRIO DE CONCRETO, DEPARTAMENTO DE APOIO E CONTROLE TÉCNICO. Concretos: massa, estrutural, projetado e compactado com rolo: ensaios e propriedades. São Paulo: Pini, 1997.

EUROCÓDIGO 2. Projeto de estruturas de betão - parte 1: Regras gerais e regras para edifícios, 2003.

FELIX, C. M. S. Monitoração e análise do comportamento de obras de arte. 2005372 p. Tese (Doutorado) - Faculdade de Engenharia da Universidade do Porto, Porto, Portugal, 2005.

FINTEL, M.; KHAN F. Effects of columns creep and shrinkage in tall structures Prediction of inelastic column shortening, American Concrete Institute Journal, pp. 957-967, December, 1969.

FONTANIVE, J. A. Análise numérico-experimental de problemas de fluência. Dissertação (Mestrado) - Universidade Federal do Rio Grande do Sul, Porto Alegre, 1982.

GARDNER, N. J.; LOCKMAN, M. J. Desing provisions for Drying Shrinkage and creep for normal-strength concrete. ACI Materials Journal, n.98, p. 159-167, 2001.

GARDNER, N. J. Comparison of predictions for drying shrinkage and creep of normal-strength concrete. Can. J. Civ. Eng., n. 31, p. 767-775, 2004. 
GARDNER, N. J.; TSURUTA, H. Is superposition of creep strains valid for concretes subjected to drying creep? ACI Materials Journal, v.101, n. 5, September-October, 2004.

GIOVAMBATTISTA, A.; ZERBINO, R. Creep of concrete after ten years of loading. In: CREEP AND SHRINKAGE - PROCEEDINGS OF THE FIFTH INTERNATIONAL RILEM SYMPOSIUM, Barcelona, Spain, 1993.

GOEL, R.; KUMAR, R.; PAUL, D. K. Comparative study of various creep and shrinkage prediction models of concrete. Journal of Materials in Civil Engineering, p. 249-260, March, 2007.

HANSEN T. C.; MATTOCK A. H. Influence of size and shape of member on the shrinkage and creep of concrete. Journal of the American Concrete Institute, pp.267-298, February, 1966.

HOLM, T. A; PISTRANG, J. Time-dependent load transfer in reinforced lightweight concrete columns. Journal of the American Concrete Institute, v. 63, $n^{\circ} 11$, November, 1966.

HOWELLS, R. W.; LARK, R. J.; BARR, B. I. G. A sensitivity study of parameters used in shrinkage and creep prediction models. Magazine of Concrete Research, v.10, n. 57, p. 589-602, December, 2005.

JAPAN CONCRETE SPECIFICATION. Tech. rep., Japan Society of Civil Engineers, 1999.

KALINTZIS, C. A. A. Estudo da fluência do concreto de elevado desempenho. 2000. 146 p. Dissertação (Mestrado) - Escola Politécnica, Universidade de São Paulo, São Paulo, 2000.

KATAOKA, L. T. Estudo experimental da deformação ao longo do tempo de lajes contínuas e simplesmente apoiadas executadas com vigotas prémoldadas de concreto. 2005. Dissertação (Mestrado) - Universidade Federal de São Carlos, São Carlos, 2005.

LYSE, I.; KREIDLER, C. L. Fourth Progress Report on Column Tests Made at Lehigh University. Journal of the American Concrete Institute, v. 3, n. 5, Proceedings n. 28, p. 317, January, 1932. 
MACHADO, M. A. S.; KATAOKA, L. T.; MARQUES, A. C.; BITTENCOURT, T. N. Parametric sensitivity analysis of different creep and shrinkage models for concrete. In: 8TH INTERNATIONAL CONFERENCE ON CREEP, SHRINKAGE AND DURABILITY OF CONCRETE AND CONCRETE STRUCTURES, 2008 Japan, v.2, pp. 1367-1372.

MARQUES, A. C. KATAOKA L. T. 2009 Ensaio de fluência: aprimoramento de suas técnicas. Revista Concreto e Construções, n. 56, Out-Nov-Dez, 2009.

MATRIX LABORATORY DA MATHWORKS. Apresenta informações sobre o MatLab. Disponível em: <http://www.mathworks.com/matlabcentral>. Acesso em: 26 ago. 2009.

$\mathrm{MAUCH}, \mathrm{S}$. Effect of creep and shrinkage on the capacity of concrete columns. In: SYMPOSIUM ON REINFORCED CONCRETE COLUMNS $61^{\mathrm{ST}}$ ANNUAL CONVENTION, 1965, San Francisco, California, pp. 299-324.

MEHTA, P. K.; MONTEIRO, P. J. M. Concreto - estrutura, propriedades e materiais. São Paulo: Pini, 2008.

MELO NETO, A. A.; CINCOTTO, M. A.; REPETTE, W. Drying and autogenous shrinkage of pastes and mortars with activated slag cement. Journal of Cement and Concrete Research, pp. 565-574, November, 2007.

MILLER, K. P. Estudo da fluência em vigas de concreto reforçado com fibras de aço, com aplicação da mecânica da fratura. 2008. Dissertação (Mestrado) Escola de Engenharia de São Carlos, Universidade de São Paulo, São Carlos, 2008.

MULLER, H. S; PRISTL, M. Creep and shrinkage of concrete at variable ambient conditions. In: CREEP AND SHRINKAGE - PROCEEDINGS OF THE FIFTH INTERNATIONAL RILEM SYMPOSIUM, Barcelona, Spain, 1993.

MULLER, H. S.; BAŽANT, Z. P.; KUTTNER, C. H. Data base on creep and shrinkage tests, RILEM Subcommittee 5 Report, RILEM, Paris, RILEM TC107CSP, 1999.

MURGIER S.; ZANNI H.; GOUVENOT D. Blast furnace slag cement: a Si and AINMR study. Comptes Rendus Chimie, v.7, April, 2004. 
DUTCH-NEN. TGB 1990: Regulations for concrete - Structural requirements and calculation methods. Tech. Rep. NEN 6720, Nederlands Normalisatie instituut, 1995.

NEVILLE, A. M. Propriedades do concreto. São Paulo: Pini, 1997.

NEVILLE, A. M.; DILGER, W. H.; BROOKS, J. J. Creep of plain and structural concrete. London, New York: Construction, 1983.

NUNES, N. L.; FIGUEIREDO, A. D. Retração do concreto de cimento Portland. BOLETIM TÉCNICO [da] Escola Politécnica da USP. São Paulo, 2007.

OFDROVIC, R. P.; ZARGHAMEE, M. S. Concrete creep and shrinkage prediction from short-term tests. ACI Materials Journal, v.93, n. 2, March-April, 1996.

OLIVEIRA, W. L. A. Análise teórica e experimental de pilares de concreto armado sob ação de força centrada com resistência média à compressão do concreto de 40MPa. 2004. 214 p. Dissertação (Mestrado) - Escola Politécnica, Universidade de São Paulo, São Paulo, 2004.

PEREIRA, P. N. Estudo das propriedades dos concretos massa e estrutural, utilizando cimento Porland pozolânico. 2001275 p. Dissertação (Mestrado) Escola Politécnica, Universidade de São Paulo, São Paulo, 2001.

PICKETT, G. Shrinkage stresses in concrete. Journal of the American Concrete Institute, v.17, n. 3, p. 165-204, January, 1946.

RAMOS, R.F. Análise de pilares de concreto aramado sob ação centrada com resistência de concreto de $25 \mathrm{MPa}$. 2001. Dissertação (Mestrado) - Escola de Engenharia de São Carlos, São Carlos, 2001.

RICHART, F. E.; STAEHLE, G. C. Fourth Progress Report on Column Tests at the University of Illinois. Journal of the American Concrete Institute, v. 3, n. 5, Proceedings v. 28, p. 279, January, 1932.

RICHART, F. E.; STAEHLE, G. C. Second Progress Report on Column Tests at the University of Illinois. Journal of the American Concrete Institute, v. 2, n. 7, Proceedings v. 27, p. 761, March, 1931. 
ROY, H. E. H., SOZEN, M. A. Ductility of concrete. In: FLEXURAL MECHANICS OF REINFORCED CONCRETE, Detroit, American Concrete Institute/ American Society of Civil Engineers, ACI SP-12, 1965.

$\mathrm{RÜSCH}, \mathrm{H}$. Concreto armado e protendido - propriedades dos materiais e dimensionamento. Rio de Janeiro: Campus, 1981.

RÜSCH, H.; JUNGWIRTH, D; HILSDORF, H. K. Creep and shrinkage - their effect on the behavior of concrete structures. New York: Springer-Verlag, 1983.

SAKATA, K. Prediction of Concrete Creep and Shrinkage. In: CREEP AND SHRINKAGE - PROCEEDINGS OF THE FIFTH INTERNATIONAL RILEM SYMPOSIUM, Barcelona, Spain, 1993, pp. 649-654.

SAKATA, K.; TSUBAKI, T.; INOUE, S.; AYANO, T. Prediction Equations of Creep and Drying Shrinkage for Wide-Ranged Strength Concrete, In: 6TH INTERNATIONAL CONFERENCE ON CREEP, SHRINKAGE AND DURABILITY MECHANICS OF CONCRETE AND OTHER QUASI-BRITTLE MATERIALS CONCREEP-6, Proceedings, Cambridge, 2001, pp. 753-758.

SAMPAIO, C. D. C. Comparação entre a modelagem numérica e experimental da deformação por fluência em vigas de concreto armado. 2004. 162p. Dissertação (Mestrado) - Escola Politécnica, Universidade de São Paulo, São Paulo, 2004.

SAKATA, K.; AYANO, T. Effect of ambient temperature and humidity on creep and shrinkage of concrete. ACI Special publication SP194-06, v. 194, May, 2000.

SALAU, M. A. Long-term deformations of laterized concrete short columns. Building and environment, n. 38, pp. 469-477, 2001.

SASSONE M. AND CHIORINO M. A. Design Aids for the Evaluation of Creep Induced Structural Effects. Shrinkage and Creep of Concrete, ACI SP-227, pp. 239-259, 2005.

SCRIVENER K. L.; KIRKPATRICK J. Innovation in use and research on cementitious material. Cement and Concrete Research, n. 38, September, 2008. 
SLATER, W. A.; LYSE, I. Second Progress Report on Column Tests Made at Lehigh University. Journal of the American Concrete Institute, v. 2, n. 7, Proceedings v. 27, p. 791, March, 1931.

STAQUET S.; ESPION B. On variability of measured strains in creep and shrinkage tests. In: 6TH INTERNATIONAL CONFERENCE ON CREEP, SHRINKAGE AND DURABILITY MECHANICS OF CONCRETE AND OTHER QUASI-BRITTLE MATERIALS - CONCREEP-6, Proceedings, Cambridge, 2001.

TAKEUTI, A. R. Comportamento resistente imediato e ao longo do tempo de pilares reforçados por meio de encamisamento com concreto de alto desempenho. 2003. 277 p. Tese (Doutorado) - Escola de Engenharia de São Carlos da Universidade de São Paulo, São Carlos, 2003.

TAZAWA, E.; MIYAZAWA, S. Autogenous shrinkage of concrete and its importance in concrete technology. In: CREEP AND SHRINKAGE - PROCEEDINGS OF THE FIFTH INTERNATIONAL RILEM SYMPOSIUM, Barcelona, Spain, 1993.

VALLADARES, L. M. Análise teórico-experimental do comportamento de pilares em concreto armado na flexão normal composta: efeitos da variação na resistência à compressão do concreto. 1997. 250p. Dissertação (Mestrado) Universidade federal de Minas Gerais, Engenharia de estruturas, Minas Gerais, 1997.

VANDAMME M.; ULM F. Nanogranular origin of concrete creep. In: PROCEEDINGS OF THE NATIONAL ACADEMY OF SCIENCES OF THE UNITES STATES OF AMERICA, Northwestern University, Evanston, 2009, pp.1-6.

VELASCO, R. V. Concreto auto-adensáveis reforçados com elevadas frações volumétricas de fibras de aço: propriedades reológicas, físicas, mecânicas e térmicas. 2008. Tese (Doutorado) - Universidade Federal do Rio de Janeiro, Rio de Janeiro, 2008.

VIDELA, C. C., COVARRUBIAS, J. P., MASANA, C. Updating concrete dryingshrinkage prediction models for local materials. ACI Materials Journal, n. 101, p. 187-198, May-June, 2004.

VIDELA, C. C. Modeling drying shrinkage of hardened chilean concretes. In: II SIMPÓSIO ÍBERO-AMERICANO SOBRE CONCRETO ESTRUTURAL. Anais SIABE 06, Rio de Janeiro, 2006. 
VIDELA, C. C.; AGUILAR, C. An update look at drying shrinkage of Portland and blended Portland cement concretes. Magazine of concrete research, v. 58, n. 7, p. 459-476, September, 2006.

WITTE, F.C, DIANA User's Manual. Release 8.1, Ed. 2, Teach, TNO DIANA BV, 2004.

WITTMANN, F. H.; BAZANT, Z.P.; ALOU, F.; KIM, J. Statistics of shrinkage test data. Cement, Concrete and Aggregates (ASTM), p.129-153, 1987.

ZIEHL, P. H.; CLOYD, J. E.; KREGER, M. E. Investigation of minimum longitudinal reinforcement requirements for concrete columns using present-day construction materials. ACI Structural Journal, v. 101, n.2, March-April, 2004. 


\section{ANEXO A \\ Aferição dos sensores de deformação}

O DT600 e DT800 requerem que os sensores elétricos sejam conectados ao aparelho utilizando ponte de Wheatstone. Para a aferição das pontes utilizadas, foi instrumentada uma barra de aço com sensor elétrico de resistência de colagem. A barra possui seção transversal circular de $6,3 \mathrm{~mm}$ de diâmetro com aço de $210 \mathrm{GPa}$ de módulo de elasticidade.

Primeiramente, foi feita a instrumentação da armadura utilizando sensor de deformação, mostrado nas figuras A.2. A carga aplicada foi de $618 \mathrm{~g}$ (figura A.4). Conhecidas a carga aplicada e as propriedades do material é possível prever a deformação da barra.

$O$ ensaio foi feito simulando um engaste da barra (A.3) de acordo com o esquema da figura A.1.

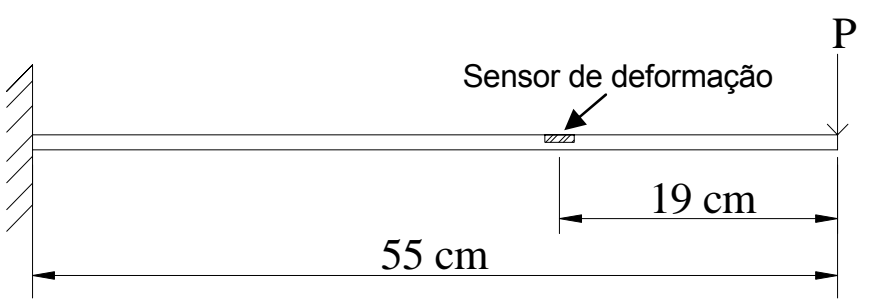

Figura A.1 - Esquema de cálculo para a previsão da deformação da barra.

A verificação da aferição da ponte é feita por meio da comparação das deformações obtidas experimentalmente e analiticamente.

Os resultados de deformação esperados foram calculados de acordo com as eq.(A-1), eq.(A-2) e eq.(A-3) da resistência dos materiais:

$$
\begin{gathered}
\varepsilon=\frac{M \cdot r}{E \cdot I} \\
I=\frac{\pi \cdot d^{4}}{64} \\
M=P \cdot L
\end{gathered}
$$

$\varepsilon$ - deformação da barra 
$\mathrm{M}$ - momento fletor

$r$ - raio da barra

E - módulo de elasticidade da barra

I - momento de inércia da barra

d - diâmetro da barra

L - distância entre o engaste e o ponto de aplicação da carga

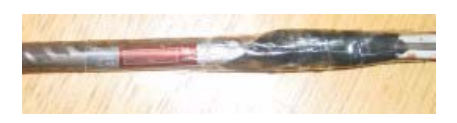

Figura A.2 - Instrumentação da armadura.

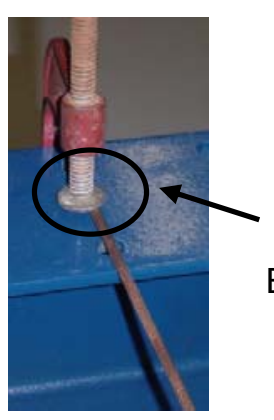

Figura A.3 - Simulação de engaste na armadura.

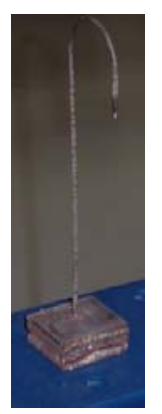

Figura A.4 - Peso utilizado para deformação da armadura.

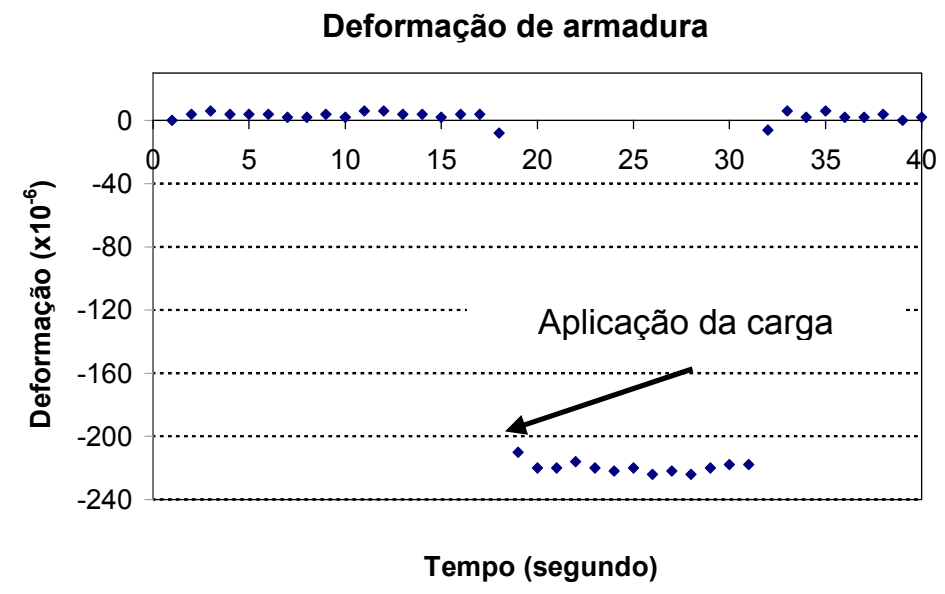

Gráfico A.1 - Resultados experimentais da armadura.

De acordo com o cálculo teórico, a deformação esperada para esta carga é de $228 \times 10^{-6}$. Como pode ser visto no gráfico A.1 a média dos resultados de leitura obtidos pelo sistema de aquisição de dados é próxima ao calculado analiticamente. Isto indica a eficácia da aferição da ponte.

A partir da comparação entre os resultados teóricos e os obtidos pelas leituras, pode-se observar que este método comprovou ser muito eficaz, já que a armadura possui um comportamento linear e elástico. 


\section{ANEXO B \\ Configurações dos sensores no programa DTransfer}

Dentre os diversos sensores que o DT600 possibilita utilização, são apresentadas apenas as configurações dos circuitos permitidos pelo equipamento aquisitor de dados para os sensores de deformação e suas respectivas linhas de comando apresentadas na tabela B.1.

Uma linha de comando típica pode ser representada por:

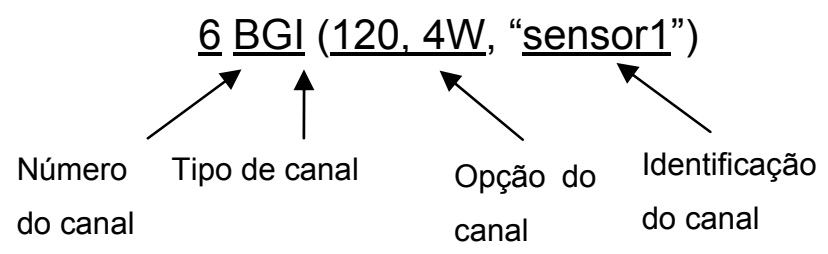

Tabela B.1 - Linhas de comando para sensores.

\begin{tabular}{|c|c|c|c|c|c|c|}
\hline $\begin{array}{l}\text { Tipo de } \\
\text { sensor }\end{array}$ & $\begin{array}{c}\text { Categoria do } \\
\text { sinal }\end{array}$ & $\begin{array}{l}\text { Tipo de } \\
\text { canal }\end{array}$ & $\begin{array}{l}\text { Opção padrão } \\
\text { do canal }\end{array}$ & Resol. & Unidade & Exemplos \\
\hline U.R.* & Current & L & $(100)^{\star *}$ & 0,01 & $\%$ & $2 \mathrm{~L}(100)$ \\
\hline Temperatura & Temp. & PT385 & & 0,1 & ${ }^{\circ} \mathrm{C}$ & 5РТ385 \\
\hline $\begin{array}{l}\text { Sensor de } \\
\text { deformação }\end{array}$ & Bridge & $\mathrm{BGI}$ & $(350)^{\star \star \star}$ & 0,1 & $\mathrm{ppm}$ & $1 \mathrm{BGI}(120,4 \mathrm{~W})$ \\
\hline
\end{tabular}

Para conectar o sensor de umidade no DT600 há necessidade da utilização de um resistor de $100 \Omega$, além de uma fonte externa extra, já embutida no aparelho (entrada AC do DT600), ligada em uma das extremidades do sensor, como pode ser visto na figura B.1. O sensor de temperatura pode ser conectado diretamente ao DT600 e DT800, conforme a configuração da figura B.2.

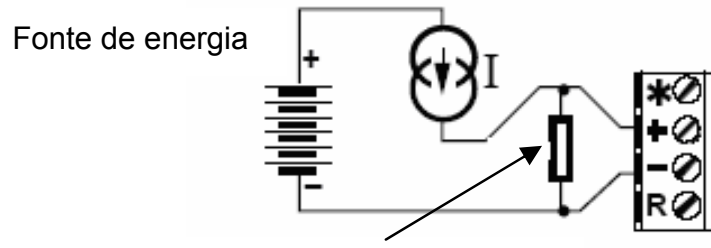

Resistor $(100 \Omega)$

Figura B.1 - Configuração do sensor de umidade (Fonte: Manual Técnico).

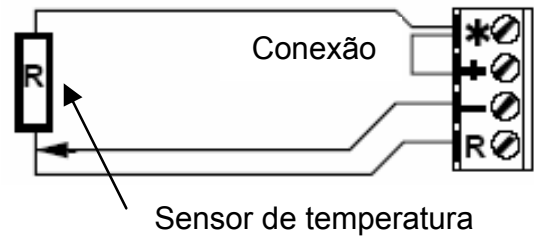

Figura B.2 - Configuração do sensor de temperatura (Fonte: Manual Técnico). 
O sensor de deformação necessita de outros 3 resistores de 120 ohms para completar a ponte de Wheatstone e realizar as medições. A ponte de Wheatstone é um dispositivo elétrico usado como medidor de resistências elétricas. O circuito utilizado para medição de deformação é composto por uma fonte de tensão, um galvanômetro e uma rede de quatro resistores, sendo três deles resistores de 120 ohms e um sensor de deformação com mesma resistência. A ponte é considerada balanceada quando a corrente do galvanômetro cai à zero. A deformação é obtida pela medição de variações muito pequenas na resistência elétrica do sensor conseguida pelo desbalanceamento da ponte. Como o sensor de deformação do concreto é de três vias e o objetivo é a medição das deformações em apenas uma direção, utiliza-se do circuito de $1 / 4$ de ponte com três vias apresentado na figura B.3. Neste circuito, uma das duas vias provenientes do mesmo terminal é conectada em série com o sensor e a outra é ligada ao resistor. Como apenas uma via está em série com o sensor, a desestabilização da via é reduzida em $50 \%$ quando comparado com a configuração de duas vias.

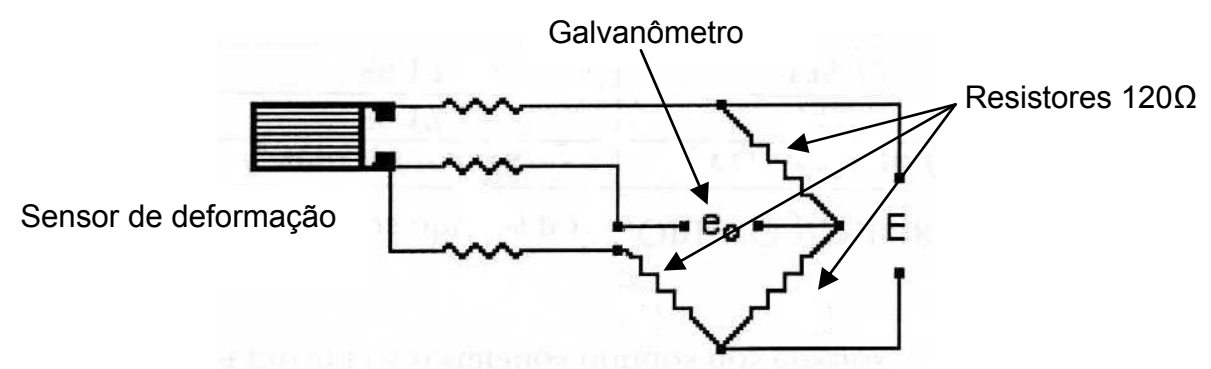

Figura B.3 - Circuito de 1/4 de ponte com três vias (ponte de Wheatstone).

Foram utilizadas duas configurações para 0 sensor de deformação das armaduras em função dos resistores existentes: $1 / 4$ de ponte e $1 / 2$ ponte. $\mathrm{Na}$ configuração de $1 / 4$ de ponte, embora o sensor de deformação da armadura seja de 2 vias, para evitar a desestabilização também é utilizada a configuração da figura B.3. Entretanto, quando se deseja a média de deformação em um elemento comprimido ou tracionado utilizam-se dois sensores ativos opostos na ponte $(1 / 2$ de ponte) como pode ser visto na figura B.4. Esta configuração permite que variações térmicas sejam compensadas mutuamente e é adequada para ensaios de longa duração. 


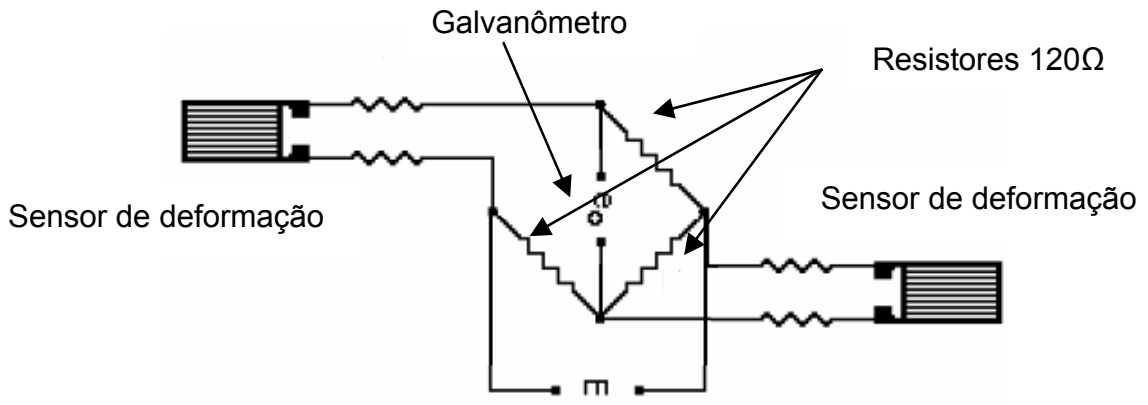

Figura B.4 - Circuito de 1/2 de ponte com duas vias (ponte de Wheatstone).

O DT600 possui dois potenciômetros internos que funcionam como elementos resistivos que completam a ponte de Wheatstone. Portanto, há necessidade da utilização de apenas um resistor externo para monitoração das deformações. Além disso, o DT600, particularmente, permite que este resistor seja compartilhado com os outros canais. A configuração do circuito considerando diversos canais ligados aos respectivos sensores e um resistor pode ser visto na figura B.5.

Sensores de deformação

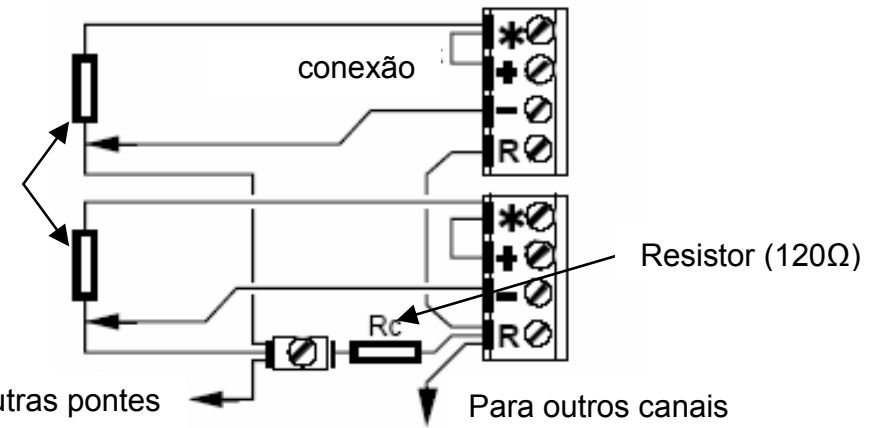

Figura B.5 - Configuração da ponte de Wheatstone com sensor elétrico (Fonte: Manual Técnico).

No DT800 há necessidade de completar a ponte externamente utilizando todos os resistores externos a ponte (figura B.6).

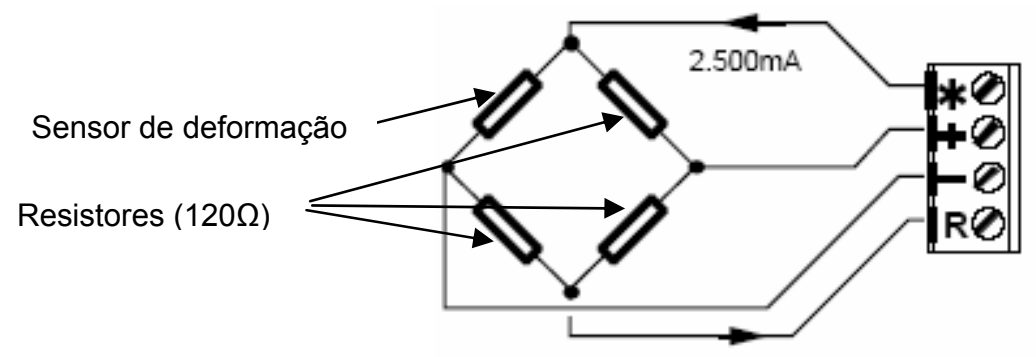

Figura B.6 - Configuração da ponte de Wheatstone com sensor elétrico (Fonte: Manual Técnico). 
Considerando que o sensor elétrico de resistência tem tolerância de 1\%, há necessidade de se utilizarem resistores de, no máximo, a mesma precisão. Portanto, o resistor utilizado para completar as pontes é $0,6 \mathrm{~W} 0,01 \% 120 \Omega$. Possui coeficiente térmico deste resistor de $0,6 \mathrm{ppm} /{ }^{\circ} \mathrm{C}$ e opera em uma faixa de temperatura de 0 a $60^{\circ} \mathrm{C}$.

As leituras do sensor de deformação feitas pelo DT600 são dadas em ppm. A conversão de ppm para deformação em $\times 10^{-6}$ (somente para dois elementos resistivos externos ao DT600) é feita utilizando a eq.(B-1).

$$
k=\frac{4}{G \cdot N}
$$

G - gage factor

$\mathrm{N}$ - número de sensores ativos na ponte 


\begin{abstract}
ANEXO C
Isobandas de tensão e deformação da simulação dos protótipos de pilares
\end{abstract}

C.1 Isobandas de deformação e tensão no concreto e na armadura para tensão de $40 \%$

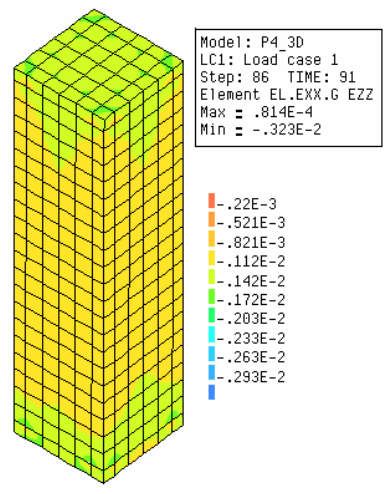

a) $1,4 \%$

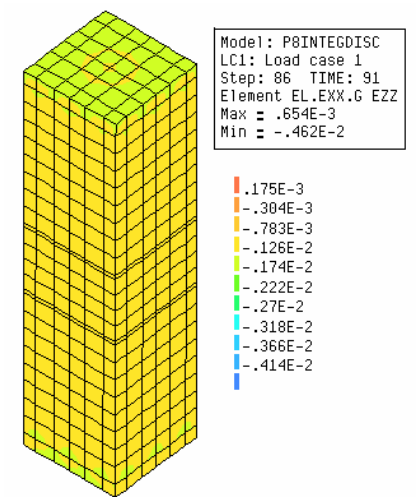

b) $2,8 \%$

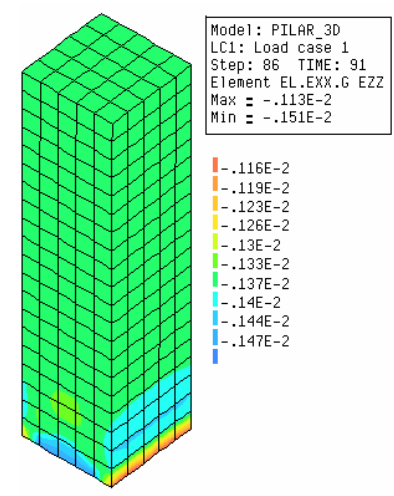

c) $0 \%$

Figura C.1 - Isobanda de deformação no concreto no Diana (ACI).

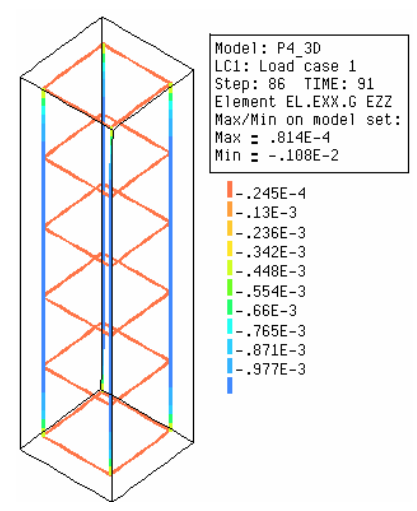

a) $1,4 \%$

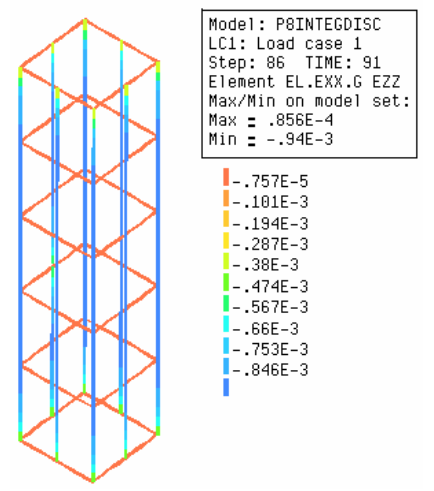

b) $2,8 \%$

Figura C.2 - Isobanda de deformação na armadura no Diana (ACI). 


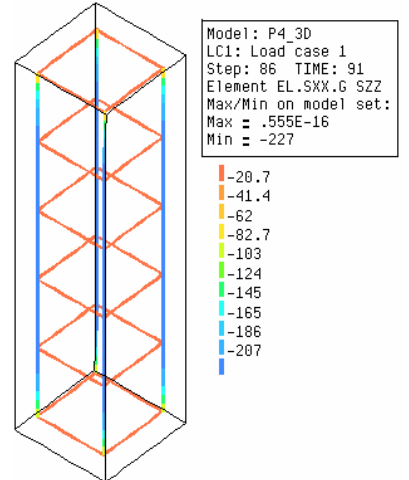

a) $1,4 \%$

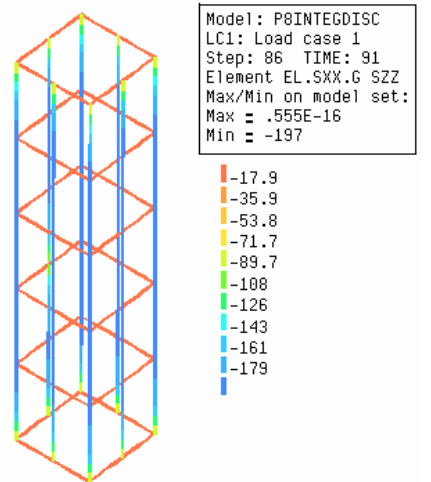

b) $2,8 \%$

Figura C.3 - Isobanda de tensão na armadura no Diana (ACI).

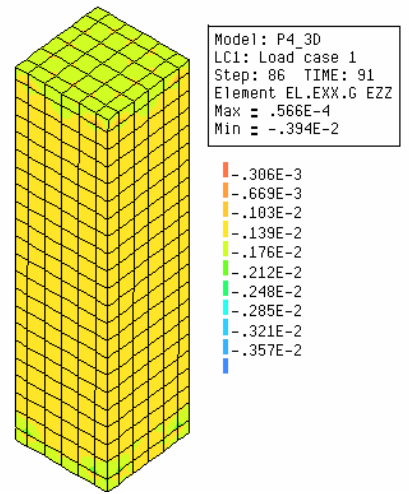

a) $1,4 \%$

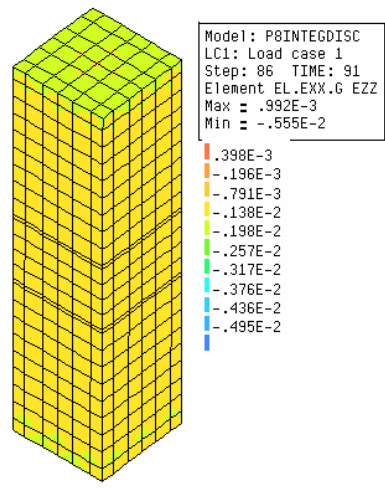

b) $2,8 \%$

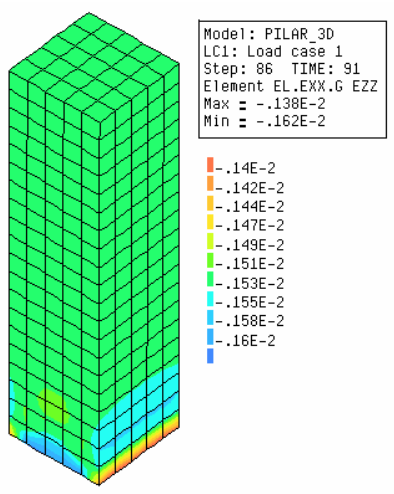

c) $0 \%$

Figura C.4 - Isobanda de deformação no concreto no Diana (CP).

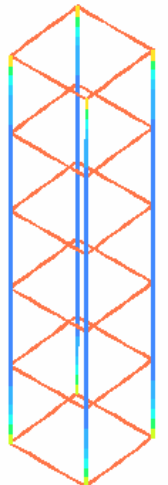

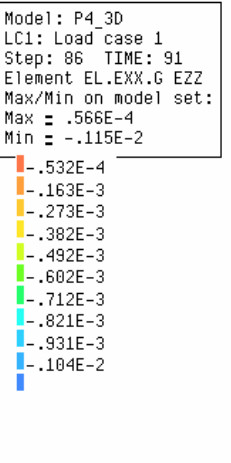

a) $1,4 \%$

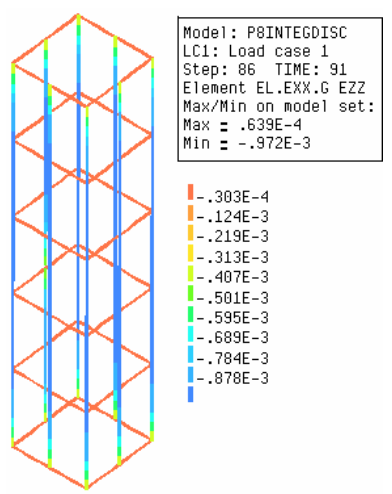

b) $2,8 \%$

Figura C.5 - Isobanda de deformação na armadura no Diana (CP). 


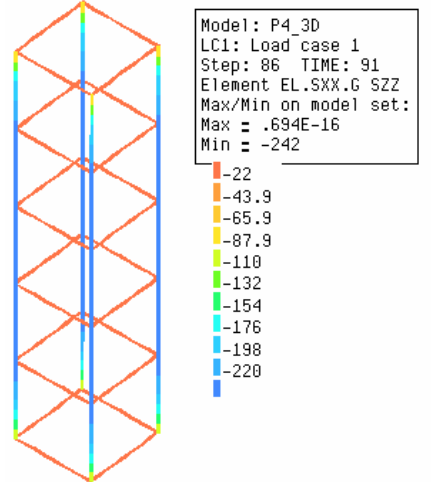

a) $1,4 \%$

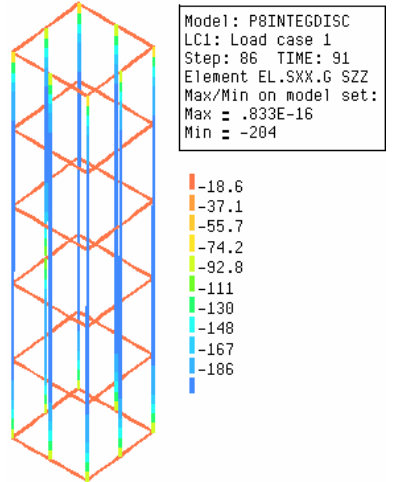

b) $2,8 \%$

Figura C.6 - Isobanda de tensão na armadura no Diana (CP).

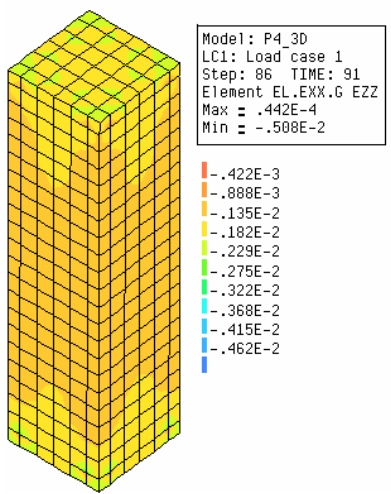

a) $1,4 \%$

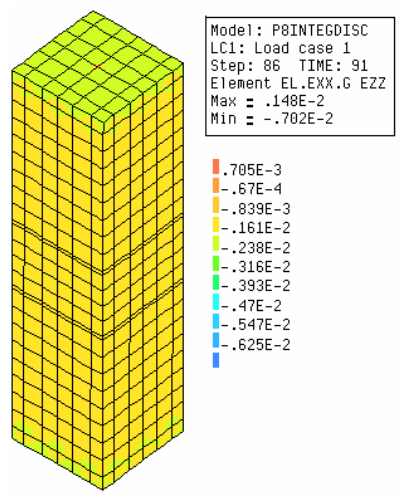

b) $2,8 \%$

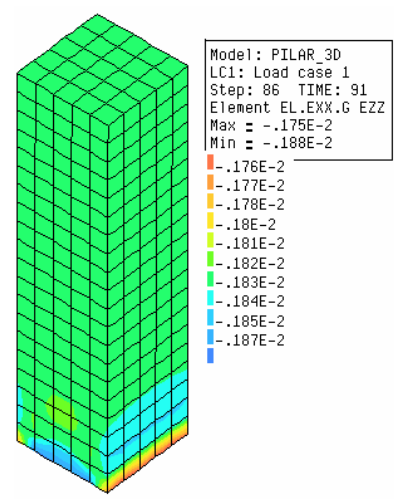

c) $0 \%$

Figura C.7 - Isobanda de deformação no concreto no Diana (P).

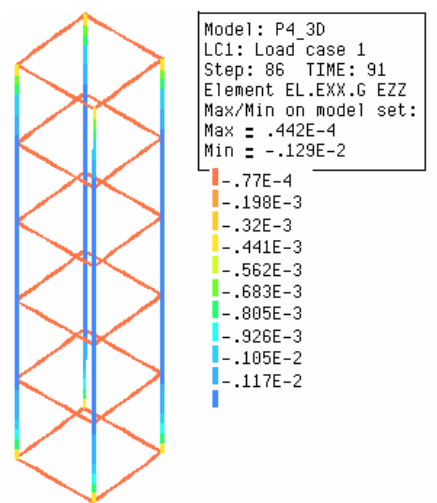

a) $1,4 \%$

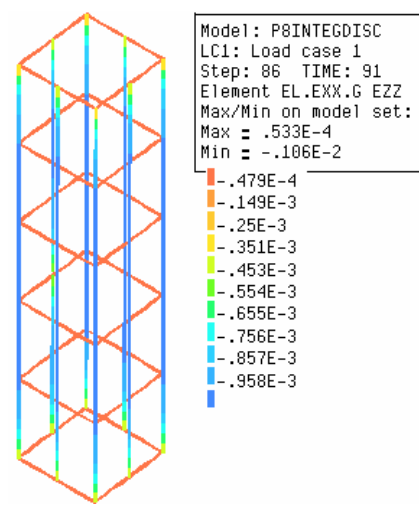

b) $2,8 \%$

Figura C.8 - Isobanda de deformação na armadura no Diana (P). 


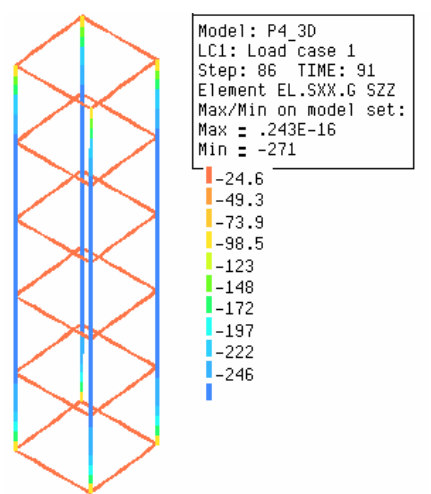

a) $1,4 \%$

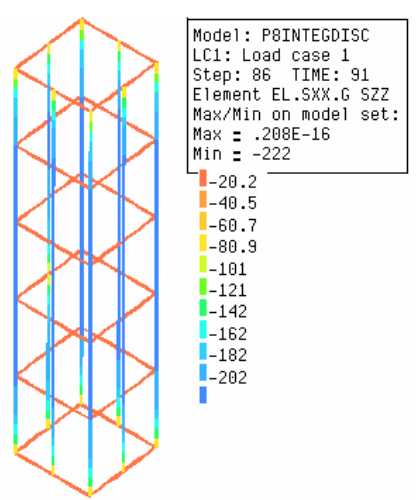

b) $2,8 \%$

Figura C.9 - Isobanda de tensão na armadura no Diana (P).

C.2 Isobandas de deformação e tensão no concreto e na armadura para tensão de $30 \%$

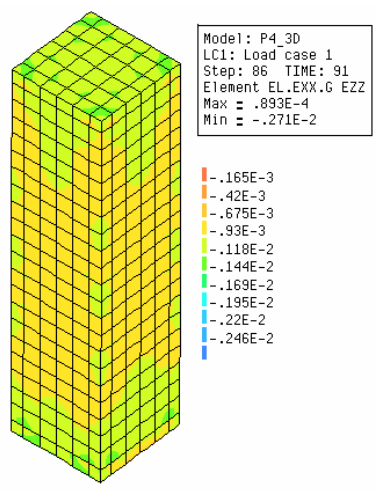

a) $1,4 \%$

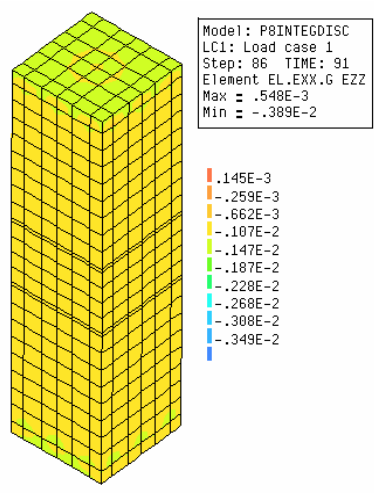

b) $2,8 \%$

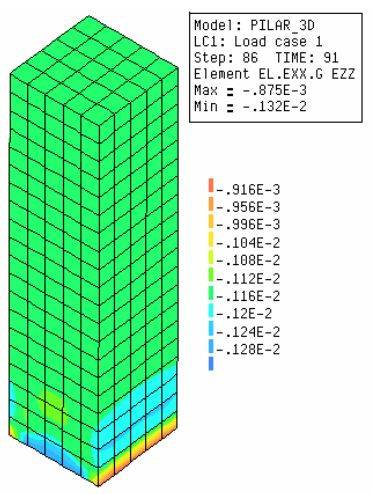

c) $0 \%$

Figura C.10 - Isobanda de deformação no concreto no Diana (ACI).

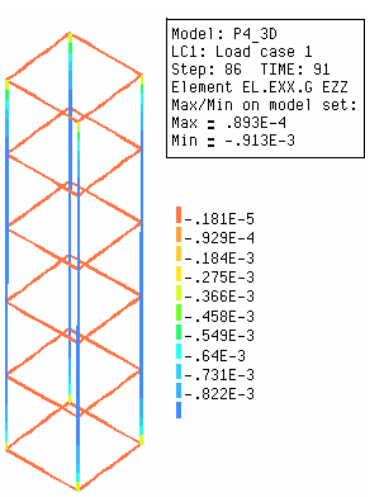

a) $1,4 \%$

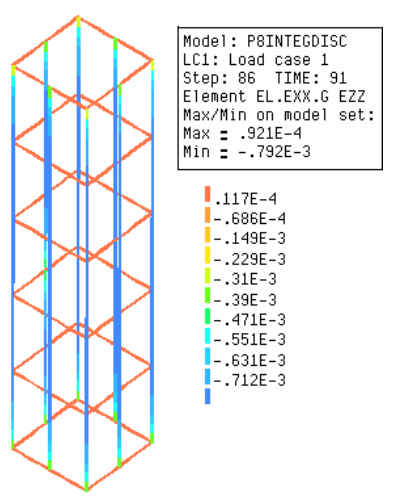

b) $2,8 \%$

Figura C.11 - Isobanda de deformação na armadura no Diana (ACI). 

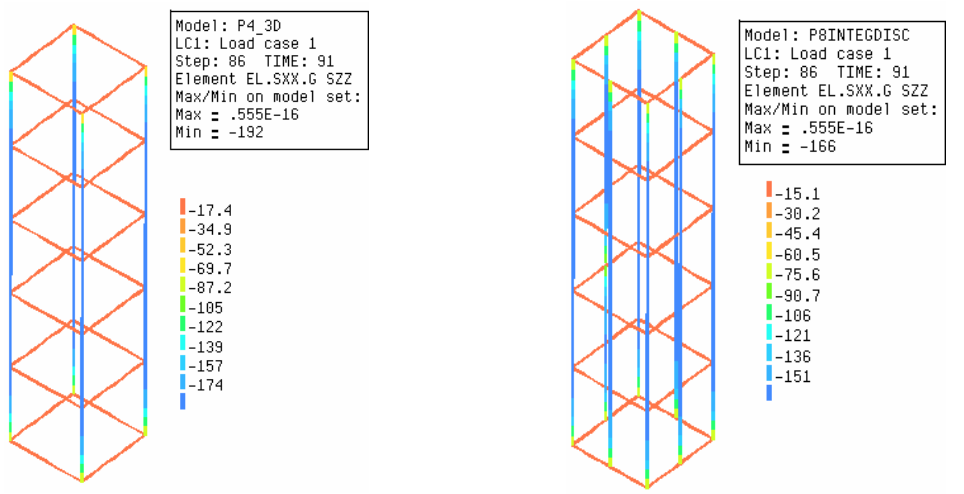

a) $1,4 \%$

b) $2,8 \%$

Figura C.12 - Isobanda de tensão na armadura no Diana (ACI).

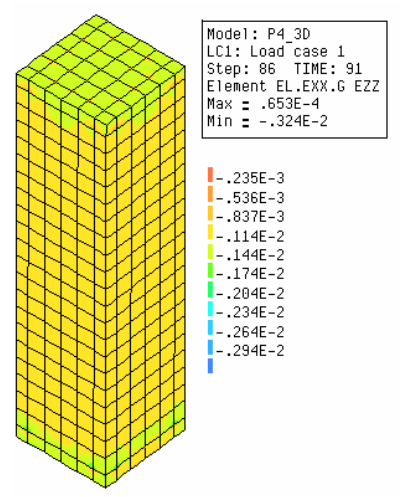

a) $1,4 \%$

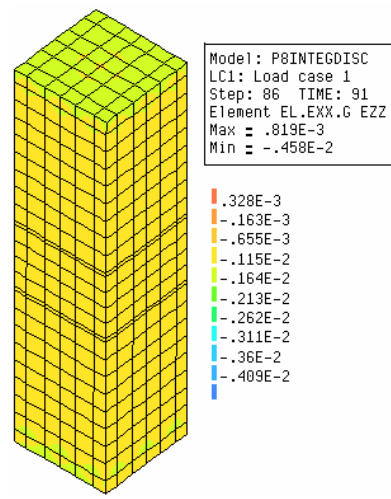

b) $2,8 \%$

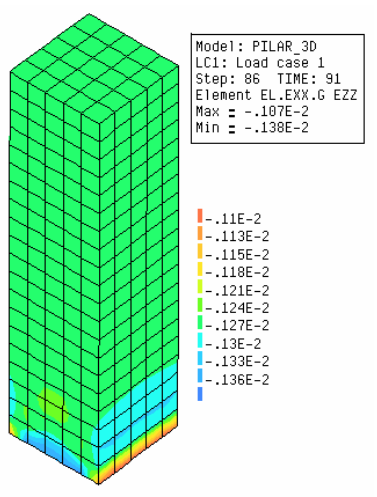

c) $0 \%$

Figura C.13 - Isobanda de deformação no concreto no Diana (CP).

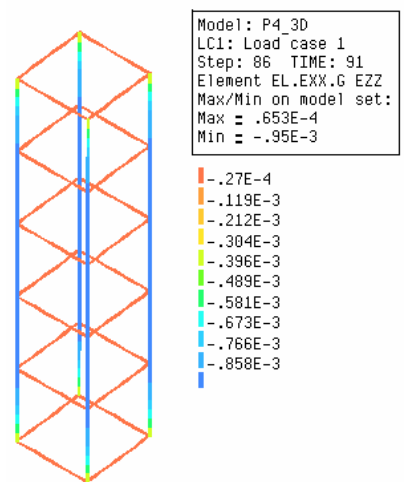

a) $1,4 \%$

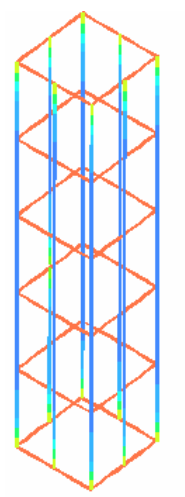

b) $2,8 \%$

Figura C.14 - Isobanda de deformação na armadura no Diana (CP). 


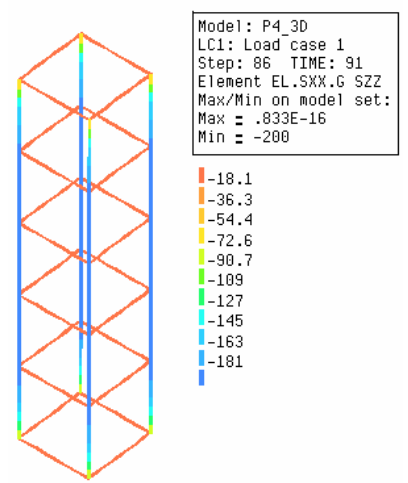

a) $1,4 \%$

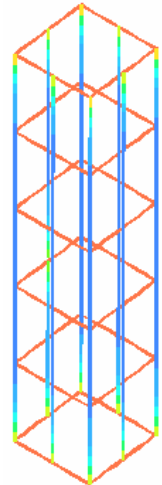

Model: P8INTEGDISC
LC1: Load case 1

LC1: Load case 1
Step: 86 TIME: 91

Element EL.SXX.G SzZ

Max/Min on model set:

$\operatorname{Max}=.694 \mathrm{E}-1$

$1-15.3$

$-30.6$

$-46$

-61.3
-76.6

-91.9
-187

$-167$

$-138$

Figura C.15 - Isobanda de tensão na armadura no Diana (CP).

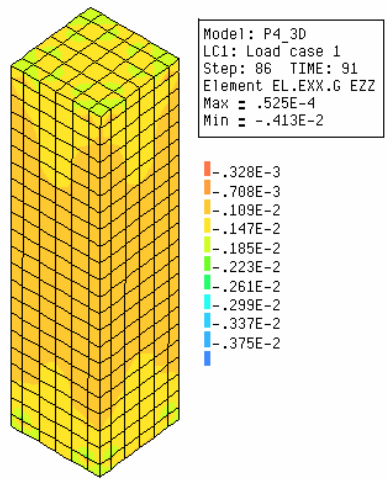

a) $1,4 \%$

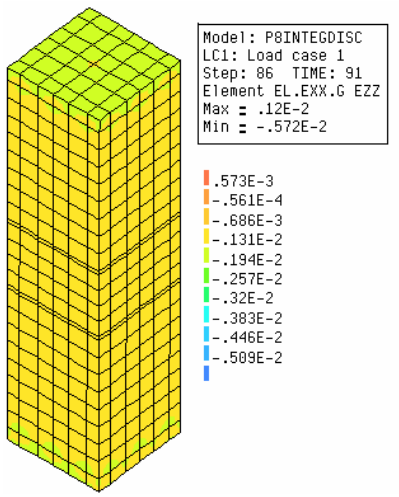

b) $2,8 \%$

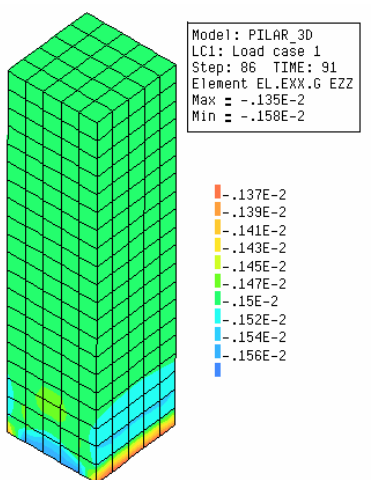

c) $0 \%$

Figura C.16 - Isobanda de deformação no concreto no Diana (P).

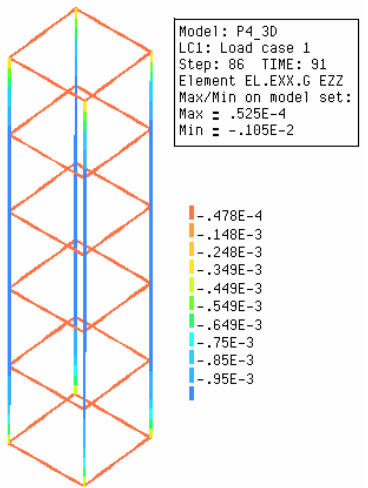

a) $1,4 \%$

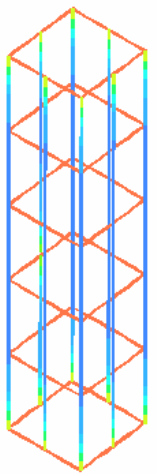

b) $2,8 \%$

Figura C.17 - Isobanda de deformação na armadura no Diana (P). 


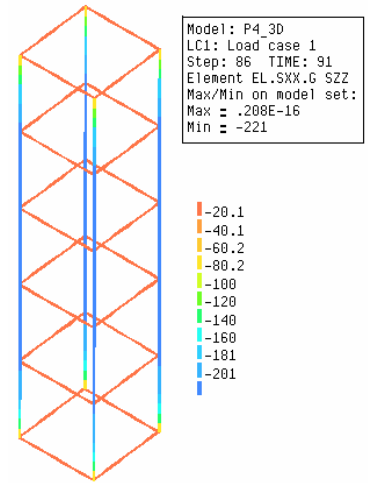

a) $1,4 \%$

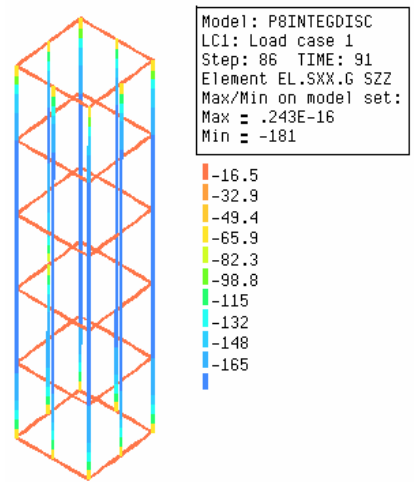

b) $2,8 \%$

Figura C.18 - Isobanda de tensão na armadura no Diana (P). 